\title{
Essays on conflict-related migration and development in the case of Afghanistan
}

Citation for published version (APA):

Loschmann, C. (2016). Essays on conflict-related migration and development in the case of Afghanistan.

[Doctoral Thesis, Maastricht University]. Boekenplan Maastricht. https://doi.org/10.26481/dis.20161014cl

Document status and date:

Published: 01/01/2016

DOI:

$10.26481 /$ dis.20161014cl

Document Version:

Publisher's PDF, also known as Version of record

\section{Please check the document version of this publication:}

- A submitted manuscript is the version of the article upon submission and before peer-review. There can be important differences between the submitted version and the official published version of record.

People interested in the research are advised to contact the author for the final version of the publication, or visit the DOI to the publisher's website.

- The final author version and the galley proof are versions of the publication after peer review.

- The final published version features the final layout of the paper including the volume, issue and page numbers.

Link to publication

\footnotetext{
General rights rights.

- You may freely distribute the URL identifying the publication in the public portal. please follow below link for the End User Agreement:

www.umlib.nl/taverne-license

Take down policy

If you believe that this document breaches copyright please contact us at:

repository@maastrichtuniversity.nl

providing details and we will investigate your claim.
}

Copyright and moral rights for the publications made accessible in the public portal are retained by the authors and/or other copyright owners and it is a condition of accessing publications that users recognise and abide by the legal requirements associated with these

- Users may download and print one copy of any publication from the public portal for the purpose of private study or research.

- You may not further distribute the material or use it for any profit-making activity or commercial gain

If the publication is distributed under the terms of Article $25 \mathrm{fa}$ of the Dutch Copyright Act, indicated by the "Taverne" license above, 


\section{Essays on Conflict-related Migration and Development in the Case of Afghanistan}

Craig Loschmann 
${ }^{\circ}$ Craig Loschmann, 2016

Published by Boekenplan, Maastricht

www.boekenplan.nl

ISBN 9789086663699

Cover image: Shah Mansour refugee camp, in northwest Pakistan. (AP Photo/Emilio Morenatti)

All rights reserved. Save exceptions stated by the law, no part of this publication may be reproduced, stored in a retrieval system of any nature, or transmitted in any form or by any means, electronic, mechanical, photocopying, recording or otherwise, without the prior written permission of the publisher, application for which should be addressed to the author. 


\title{
Essays on Conflict-related Migration and Development in the Case of Afghanistan
}

\author{
DISSERTATION \\ to obtain the degree of Doctor at Maastricht University, \\ on the authority of the Rector Magnificus, \\ Prof. Rianne M. Letschert, \\ in accordance with the decision of the Board of Deans, \\ to be defended in public \\ on Friday 14 October 2016, at 10:00 hours. \\ by \\ Craig Loschmann
}




\section{Supervisor:}

Prof. Dr. Khalid Koser

\section{Co-Supervisor:}

Prof. Dr. Melissa Siegel

\section{Assessment Committee:}

Prof. Dr. Ronald Skeldon (Chair), Maastricht University/ University of Sussex

Prof. Dr. Hein de Haas, Maastricht University/ University of Amsterdam

Dr. Ceri Oeppen, University of Sussex

Dr. Carlos Vargas-Silva, University of Oxford 



\section{Acknowledgements}

This dissertation is the culmination of what has been a long and winding road that began years before ever stepping foot in Maastricht. It would not exist without the untiring support of so many of which I am truly grateful.

I am fortunate to have been able to rely on two exceptional supervisors who each in their own way have been instrumental throughout my research. To Khalid, I knew from the day we first discussed my interests that I would be able to count on your straightforward and sound advice on matters both big and small. The feedback and encouragement you have provided have been invaluable, and I hope to continue to anxiously receive it in the years to come. And to Melissa, I am forever in your debt for welcoming me into the migration group and providing the opportunity to conduct the research found here. It has been a pleasure working with you, and I can only hope that your relentless positive energy and can-do attitude has rubbed off if even in the slightest.

I want to thank the members of the assessment committee - Prof. Ronald Skeldon, Prof. Hein de Haas, Dr. Ceri Oeppen and Dr. Carlos Vargas-Silva - for taking the time to review this dissertation. It is an honor to have my work assessed by such a highly esteemed group of scholars whose own research has been such an influence. The final product found here is unquestionably improved because of your insightful comments.

Within Maastricht University, I am particularly appreciative of Prof. Franziska Gassmann, Prof. Pierre Mohnen and Prof. Wim Naudé for providing early feedback on individual papers. Additionally, I am thankful to Mindel van de Laar, Eveline in de Braek, Susan Roggen and Herman Pijpers for providing exceptional support whether it was administrative, technical or otherwise.

I would be remiss not to recognize Nassim Majidi, Hervé Nicolle and the rest of the hardworking and talented team at Samuel Hall Consulting who were in charge of the data collection efforts in Afghanistan on which my research so heavily relies. Similarly, I need to acknowledge the original IS Academy migration team - Sonja, 
Katie, Ozge, Silja, Natasja and Katherina - for putting in so much of the hard work before I even arrived, and which I have benefited from so greatly.

I also want to give a heartfelt thanks to my many colleagues in Maastricht with whom I have shared this journey and who have made it so very rewarding. First to the migration research team - Michaella, Katrin, Elaine, Jenny, Biljana, Ayla, Nora, Andrea and all others including those already mentioned - it has been a pleasure to share those many occasions when we were all able to get together and discuss our varied research projects, and lives more generally. Each of you continues to impress me, and I look forward to further interaction in the years to come. To those of you with whom I began this $\mathrm{PhD}$ - George, Julieta, Simone, Lorena, Andres, Andi, Tash, Ortrun, Eleni, Yesuf, Anthony, Connie, Rhena and Charlotte - thanks for all the fond memories both inside the school and out on the town. The same goes to the rest of you in Maastricht who made my intermittent time there so very enjoyable, and moreover comfortable if you so graciously hosted me in the later years.

Lastly, I would like to express my deepest gratitude to my family, both near and far. Your encouragement over the years has not gone unnoticed or unappreciated. To my parents, you have endured my many whims with more comprehension than I perhaps deserve. What can I say to adequately express how important it has been to know you have been and will continue to be in my corner. And finally to my wife, Laura, you have been a crutch for me to lean on far more often than I care to admit. I am in constant awe of your great intellect and keen sensibility, and am without a doubt a better version of myself with you by my side. 


\section{Table of Contents}

\section{Chapter 1: Introduction}

$\begin{array}{lll}1.1 & \text { Setting the Scene } & 15\end{array}$

$\begin{array}{lll}1.2 & \text { Clarifying Concepts } & 18\end{array}$

$\begin{array}{lll}1.3 & \text { Research Overview } & 21\end{array}$

1.4 Theoretical Review 24

$\begin{array}{lll}1.5 & \text { Afghanistan as a Case Study } & 29\end{array}$

$\begin{array}{lll}1.6 & \text { Datasets } & 37\end{array}$

$\begin{array}{lll}1.7 & \text { Concluding Remarks } & 40\end{array}$

Works Cited 41

Chapter 2: The Influence of Vulnerability on Migration Intentions

2.1 Introduction $\quad 47$

2.2 Theoretical Approach 49

2.3 Methodology 51

$\begin{array}{lll}2.4 & \text { Results } & 59\end{array}$

2.5 Conclusion $\quad 69$

$\begin{array}{ll}\text { Works Cited } & 72\end{array}$

Chapter 3: Revisiting the Motivations behind Remittance Behavior

$\begin{array}{lll}3.1 & \text { Introduction } & 75\end{array}$

$\begin{array}{lll}3.2 & \text { Literature Review } & 77\end{array}$

3.3 Methodology $\quad 82$

$\begin{array}{lll}3.4 & \text { Results } & 86\end{array}$

3.5 Conclusion $\quad 88$

$\begin{array}{ll}\text { Works Cited } & 90\end{array}$

Chapter 4: The Long-term Consequences of Displacement:

Measuring Differences in Education \& Nutrition

$\begin{array}{lll}4.1 & \text { Introduction } & 93\end{array}$

4.2 Literature Review $\quad 96$

$\begin{array}{lll}4.3 & \text { Methodology } & 98\end{array}$ 
$\begin{array}{lll}4.4 & \text { Results } & 105\end{array}$

$\begin{array}{lll}4.5 & \text { Conclusion } & 107\end{array}$

$\begin{array}{ll}\text { Works Cited } & 110\end{array}$

$\begin{array}{ll}\text { Appendix } & 113\end{array}$

Chapter 5: The Occupational Choice of Forced Migrants upon Return

$\begin{array}{lll}5.1 & \text { Introduction } & 121\end{array}$

5.2 Literature Review 123

$\begin{array}{lll}5.3 & \text { Methodology } & 126\end{array}$

$\begin{array}{lll}5.4 & \text { Results } & 131\end{array}$

$\begin{array}{ll}5.5 \text { Conclusion } & 139\end{array}$

Works Cited 142

Appendix 146

Chapter 6: Does Shelter Assistance Reduce Poverty?

$\begin{array}{lll}6.1 & \text { Introduction } & 149\end{array}$

6.2 Background 152

$\begin{array}{lll}6.3 & \text { Methodology } & 155\end{array}$

$\begin{array}{lll}6.4 & \text { Results } & 166\end{array}$

6.5 Conclusion 172

$\begin{array}{ll}\text { Works Cited } & 174\end{array}$

$\begin{array}{ll}\text { Appendix } & 178\end{array}$

Chapter 7: Conclusions

7.1 Research Summary 185

$\begin{array}{lll}7.2 & \text { Critical Reflections } & 189\end{array}$

7.3 Current Limitations and Future Lines of Study 193

$\begin{array}{lll}7.4 & \text { Final Remarks } & 196\end{array}$

$\begin{array}{ll}\text { Works Cited } & 197\end{array}$

$\begin{array}{ll}\text { Valorization } & 199\end{array}$

Biography $\quad 203$

MGSoG Dissertation Series $\quad 205$ 


\section{Figures and Tables}

\section{Figures}

Figure 1: Global forced migrant population since 2000 17

Figure 2: Migration patterns in Afghanistan since $2000 \quad 33$

Figure 3: Dataset per chapter $\quad 37$

Figure 4: Location of internally displaced households, by province 101

Figure 5: Distribution of households, by province 158

Figure 6: Multidimensional poverty index (MPI), by province 163

\section{Tables}

Table 1: Description of dimensions, indicators and thresholds of household deprivation $\quad 56$

Table 2: $\quad$ Migration intentions $\quad 58$

Table 3: $\quad$ Summary statistics (\%) 59

Table 4: Household deprivation on each indicator by dimension (\%) 60

Table 5: Statistically significant mean difference across migration intentions 63

Table 6: Dimensional household vulnerability (\%) 64

Table 7: Multidimensional household vulnerability (\%) 64

Table 8: Marginal effect of individual indicators of deprivation on migration intentions 66

Table 9: Marginal effect of dimensional vulnerability on migration intentions 68

Table 10: Marginal effect of multidimensional vulnerability on migration intentions $\quad 69$

Table 11: Theoretical relationships $\quad 81$

Table 12: Summary statistics $\quad 84$

Table 13: Marginal effect of remittance behavior $\quad 87$

Table 14: Summary statistics 103

Table 15: Relative risk ratio of school attendance 106

Table 16: Relative risk ratio of food security 106

Table 17: Marginal effect of dietary diversity 107

Table 18: Summary statistics $\quad 130$

Table 19: Self-selection estimation 134 
Table 20: Occupational choice model, comparing non-migrants to $\begin{array}{ll}\text { return migrants } & 136\end{array}$

Table 21: Occupational choice model, with migration and return experience 138

Table 22: Dimensions, indicators and thresholds for household deprivation 156

Table 23: Summary statistics $\quad 159$

Table 24: Household deprivation $\quad 161$

Table 25: Unadjusted headcount ratio $(\mathrm{H})$, intensity $(\mathrm{A})$ and adjusted headcount ratio $\left(\mathrm{M}_{0}\right) \quad 162$

Table 26: Overall multidimensional poverty 162

Table 27: Balance statistics 167

Table 28: ATET of the adjusted headcount ratio (M0) 168

Table 29: ATET of the unadjusted headcount ratio $(H) \quad 169$

Table 30: Mantel-Haenszel bounds for Outcome $=$ MPI 171

Table 31: Mantel-Haenszel bounds for Outcome = Dietary Diversity 172 

So they took the only course remaining: they left. On foot, by car, by motorcycle, across an open country of crabgrass and gravel, they left. Across long harsh miles, taking their clothes and their bedding and their animals, they left. Some did not quit until reaching Pakistan. But most, like Hazrat, stopped by the grassy riverbank near Laghman's main highway, far enough from trouble but close enough to the world they knew, and erected a new village of tarpaulin and plastic.

Anand Gopal (2014, p. 221). No Good Men among the Living: America, the Taliban, and the War through Afghan Eyes. 



\section{Chapter 1}

\section{Introduction}

\subsection{Setting the Scene}

Migration is by many accounts one of the key defining issues of our day. Although the movement of individuals and whole communities is indeed as old as humanity itself, human mobility in today's increasingly interconnected world is exceptional not only in scale, but more notably in scope (Goldin et al., 2012; Castles et al., 2013). That is not to discount a more nuanced consideration of contemporary migration patterns in comparison to times past (see, e.g., Czaika \& de Haas, 2014), but as Skeldon $(2015$, p. 2357) remarks, it "seems incontrovertible that there are more people moving in more ways in the world today than ever before".

Corresponding to a growing appreciation of contemporary migration, there is also a heightened debate concerning the link between migration and wider development processes. In particular, the role of migration as a driver of human development is increasingly recognized by a range of actors outside of traditional scholarly circles including international organizations, government bodies and civil society groups. The inclusion of migration as a subject matter, or migrants as a group, in five of the 17 recently agreed upon Sustainable Development Goals is just the latest result of a years-long effort to mainstream migration-related themes into development policies (Bakewell, 2015). As popular interest in the migration-development nexus gains momentum, it appears to be an opportune moment to reinvest time and effort in advancing our understanding of the deeper complexities related to migration and development in order to maintain a well-informed discussion.

In this regard, empirical research on the issue of migration and development has risen steadily since the early 1990s, resulting today in a robust literature that investigates earlier theoretical propositions (Clemens et al., 2014). In the past few years alone, the field has benefited considerably from greater interest across a wider range of disciplines drawing on a broad mix of new methods and better sources of data. As such, there is at present an ever more thoughtful scholarship on 
a wide variety of sub-topics related to the way migration and development processes influence one another. This impressive growth in the literature, however, is not without its shortcomings.

For one, the narrative thus far has been arguably dominated by a focus on movement from low- to high-income countries, otherwise considered South-North migration (Hujo \& Piper, 2007; Ratha \& Shaw, 2007). Especially where empirical research is concerned, the bulk of work has been based on a few well-established corridors towards North America and Western Europe. Yet we know this is not nearly close to a full account of migration experiences around the globe, painting a rather biased picture overall. The most recent figures show migration between developing countries is at least as large as that between developing and developed countries (UNDESA, 2013). While one reaction may be to dedicate more attention towards South-South migration as its own general area of study, this may actually be of little value due to the great level of heterogeneity and contextual difference across the entire Global South (Bakewell, 2009). A more sensible approach, then, may be to carry out individual, context-specific studies on the ways in which migration and development interrelate in some of the more marginalized regions of the world.

In a similar vein, a second limitation relates to the noticeable gap on less voluntary forms of migration (Black, 2001; Castles, 2003; Bakewell, 2007; Czaika, 2009; Lindley, 2010; Hugo et al., 2012). According to UNHCR (2016) and as indicated in Figure 1, the number of individuals displaced around the world - either within or outside their countries of origin due to conflict, generalized violence and persecution, among others - has increased considerably over recent years and is currently estimated at 65.3 million. ${ }^{1}$ While this figure is the highest since modernday recordkeeping began, and is anticipated to rise even further in the near-term (UNHCR, 2015b), it is important to remind ourselves that forced migration due to conflict has been a constant throughout history (Castles, 2003; Bakewell, 2007). Therefore, taking a deeper look at the complex link between migration and

\footnotetext{
${ }^{1}$ It is well recognized that official statistics are more than likely underestimating the true number of displaced individuals around the world due to the difficulties in surveying such a hard-to-reach population.
} 
development processes within a setting characterized by conflict seems not only timely, but relevant more generally. It is precisely this topic with which this dissertation is concerned.

\section{Figure 1: Global forced migrant population since 2000}

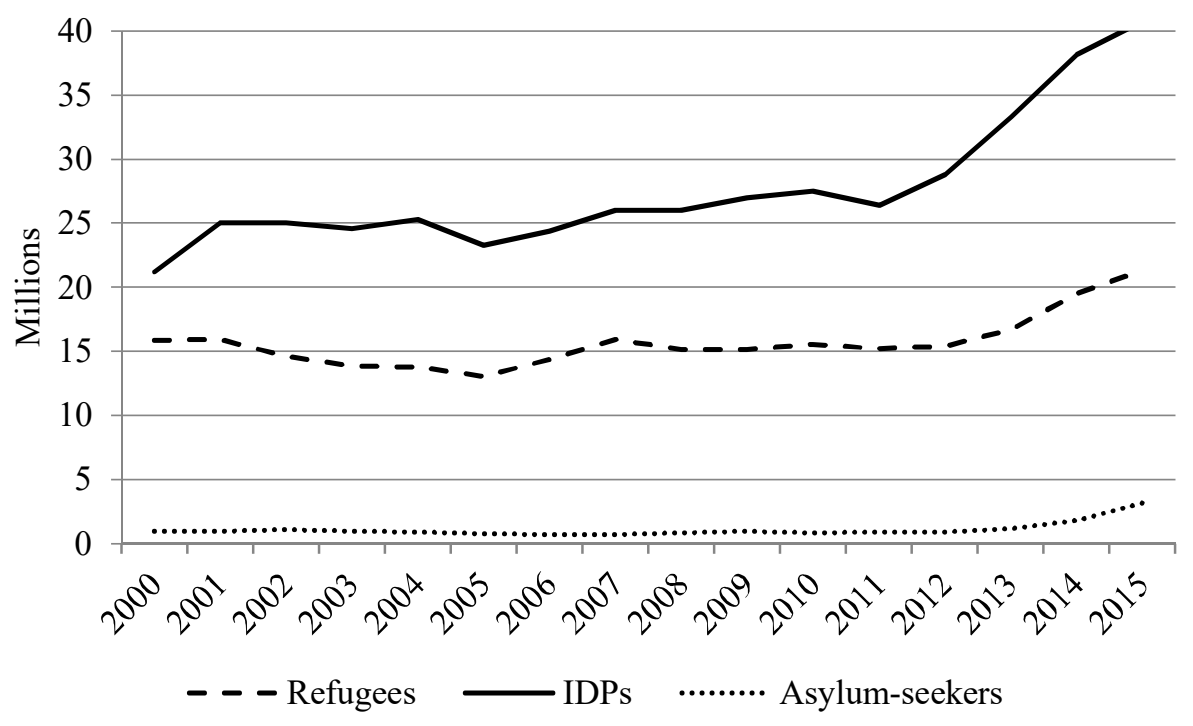

Source: UNHCR, 2016; UNHCR, 2015a; IDMC, 2015.

With the above providing an overarching motivational influence, the empirical essays that make up this dissertation explore the relationship between conflictrelated migration and development within the (post-) conflict setting of Afghanistan. Taking advantage of two unique micro-level datasets seldom available for such a high-risk environment, these studies tackle a range of issues related to the causes and consequences of conflict-related migration, and also assess an important policy response. Moreover, the varied types of migration are considered including cross-border flows, internal displacement and return migration. The ability to do so is not simply convenient but appropriate given the prevalence of these three particular migration trends in Afghanistan over the last four decades. As such, the work as a whole makes a valuable contribution not only to the specific literature on migration in the Afghan context, but to the general literature on migration and development by providing evidence from a conflictaffected setting rarely in focus. 
The aim of this opening chapter is to introduce the discussion around the relationship between conflict-related migration and development. With this in mind, the following section first makes clear some of the fundamental conceptual issues regarding how these terms are understood in order to minimize possible ambiguity. Next, a more detailed overview of the substantive essays at the core of this dissertation is given to illustrate an overall coherence to the entire body of work. A review of the theoretical debate concerning the migration-development nexus is then provided, helping to anchor those studies within a general theoretical framework. The case of Afghanistan is next discussed which helps situate the ensuing research within their particular conflict-affected context. Lastly, the specific datasets relied on for the analyses included here are described in greater detail.

\subsection{Clarifying Concepts}

A natural point of departure to the discussion around the relationship between conflict-related migration and development is language. What do we mean when we say conflict-related migration, in contrast to forced migration for example? And what are we referring to with development, which could indicate anything from national economic growth to greater individual opportunity? Both terms are inherently complex from a conceptual and political point of view and encompass a wide-range of possible interpretations, some of which are more significant for the work found in this dissertation than others. As such, this section makes a point to define each while addressing key conceptual issues.

It is common to hear migration being discussed not so much as a general phenomenon, but rather based on simplistic and arguably unqualified typologies. Typically, such typologies are based on dichotomous classifications which attempt to provide a clear-cut distinction between different forms of migration (King, 2012). Ubiquitous examples include internal vs. international migration, temporary vs. permanent migration and regular vs. irregular migration. More recently another traditional dichotomy has received considerable attention, voluntary vs. forced migration. The fact that there are currently a great number of individuals and families around the world fleeing conflict and persecution has resulted in an intensified public conversation about what it means to be truly considered a forced migrant. Such a conversation takes on a particularly practical significance 
considering the legal rights and status such a label so readily provides following largely accepted international agreements. ${ }^{2}$

Traditionally, the literature on forced migration focuses on refugees, asylumseekers and internally displaced persons (IDPs), while more recently even environmental- or development-induced migrants have entered into the debate. Alternatively, the literature on voluntary migration concentrates on labor or economic migrants, broadly meaning anyone that moves in order to better their socio-economic situation. Yet it is well recognized that such a distinction between forced and voluntary migration is highly problematic (Black, 2001; Bakewell, 2007; Kronenfeld, 2008; de Haas, 2009; Van Hear et al., 2009; de Haas, 2011; Koser \& Martin, 2011). By definition, forced migrants are implicitly assumed to have little to no agency in their decision-making process, and are instead simply influenced by the structures of their environment (Bakewell, 2010; de Haas, 2011). While this may indeed be the case in extreme circumstances such as slavery and deportation, for the most part it is uncommon for forced migration to be truly involuntary in the strictest sense, and more likely there are elements of both coercion and choice in the decision-making process (Turton, 2003; Van Hear et al., 2009; Williams, 2013; de Haas, 2014).

Moreover, aside from systematic insecurity, conflict-affected contexts are often rife with severe poverty and an overall lack of economic opportunity. In such an environment, any mixture of motivating factors - be they economic, political or socio-cultural - may be at the heart of the decision to move, making any clear-cut distinction based on such factors untenable (Kronenfeld, 2008; Van Hear et al., 2009; Lindley, 2010; Koser \& Martin, 2011). Those underlying causes might also shift in the course of the migration event itself. A refugee, for example, originally fleeing persecution might begin to prioritize their socio-economic betterment once abroad and as such refrain from returning even when the political and security situation improves back home (Van Hear et al., 2009). Overall then, it seems evident that the classification of migration into definite, and often dichotomous, categories is likely to be far more complex on the ground than may seem from the vantage point of an academic or government office.

\footnotetext{
${ }^{2}$ See the 1951 Refugee Convention and the subsequent 1967 Protocol.
} 
In an effort not to get bogged down by such unaccommodating terminology from the outset, the notion of conflict-related migration is used in this dissertation to indicate the whole spectrum of migration occurring in a conflict-affected setting regardless of voluntariness. That includes those individuals unequivocally forced from their homes due to a physical threat to their safety, those moving primarily for economic reasons, and those migrating for any mixture of reasons in between. Still, it is worth noting that certain studies in this work do focus exclusively on forced migration per se, both internally and abroad, in contrast to conflict-related migration more generally. In such cases, the way in which forced migration is defined is made clear in the respective chapters, taking into consideration the individuals' own principal reason for leaving their community of origin.

That brings us to the notion of development. The conceptualization of development throughout this dissertation falls in line with the human development approach originating from the works of ul Haq (1995) and Sen (1999), and enshrined in UNDP's Human Development Reports. From this perspective, people are placed squarely at the center of the discussion as they are considered both beneficiaries and drivers of development (UNDP, 2010). Broadly speaking, the condition of development is understood as individual well-being based on the "capability to lead the kind of lives that people have reason to value" (Dreze \& Sen, 2013, p. 43). Implicit in this conceptualization of development is the freedom, or capability, to choose a desired functioning that represents any activity or state of being one might value or find important (Alkire et al., 2014). Examples of a typical functioning include the desire to be healthy, well-nourished, safe, educated, employed and to enjoy an overall decent standard of living, among many others depending on the particular circumstances of time and place.

Central to the human development approach is the recognition of the multidimensional nature of poverty and well-being. As Sen (2000, p. 18), himself, emphasizes: "Human lives are battered and diminished in all kinds of different ways, and the first task ... is to acknowledge that deprivations of very different kinds have to be accommodated within a general overarching framework". A multidimensional approach effectively complements a single resource-based or monetary measure by considering multiple deprivations, and their overlap, along a range of other dimensions arguably essential to human welfare. 
From a practical point of view, such an approach to development is intrinsically "policy related and evaluative or indicator led" (Sumner, 2008, p. 11). Indeed, a human development framework is naturally interested in a set of measureable indicators used to identify a state of being or outcomes of change. While potentially critiqued for a short-term outlook and paternalistic undertones, normative reasoning that takes into consideration what those afflicted by poverty associate with being poor is at the foundation of such an approach (Alkire et al., 2014). Overall, then, a multidimensional approach to human development provides a useful framework to measure progress, and is therefore particularly valuable for empirical research like that which is found here.

\subsection{Research Overview}

As noted, the empirical essays included in this dissertation explore the relationship between conflict-related migration and development in the case of Afghanistan, a country that has witnessed some of the highest levels of refugee outflows, internal displacement and return migration in recent time. Each study can be categorized within one of three main sub-themes: 1) the causes of conflict-related migration; 2) its consequences for human development; and 3) policy response. In addition, the analyses look at a range of different types of conflict-related migration relevant for this particular context. Overall then, this work as a whole provides a uniquely wide-ranging account of the Afghan case as it relates to conflict-related migration and development.

\section{Causes of Conflict-related Migration}

Falling within the first sub-theme, Chapter 2 explores the causes of conflict-related migration by asking how household vulnerability might influence intentions to migrate. The application of a multidimensional vulnerability index is motivated by the notion that in an insecure setting like that of Afghanistan it is reasonable to assume a particularly fine line between voluntary and forced migration. As such, it is necessary to approach the subject through a broad spectrum which does not presuppose migration is strictly economic in nature, and takes into account both exposure to risk and lack of entitlements. The principal contribution is precisely this re-conceptualization of the underlying factors driving the motivation to migrate. While the concept of poverty is commonly used to investigate the causes 
of migration especially in contexts of labor migration, the use of this notion of vulnerability is both novel and appropriate given the systematic risks in the Afghan context.

Chapter 3 goes a step further, and investigates whether there is evidence of migration as a household risk-coping strategy. To do so, the analysis looks at the motivations behind remittance behavior differentiated by the way in which the migration episode was originally financed. By considering remittance behavior in relation to debt-financed migration in particular, it is possible to check for an implicit contractual agreement between migrant and household at origin which would suggest a household strategy. This study contributes to an extensive literature that focuses on testing a now well-established theoretical understanding of migration as a household arrangement, with direct implications for remittance behavior. However, it is the first to do so in the conflict-affected context of Afghanistan, which is argued to be relevant due to the high degree of insecurity and uncertainty over recent years.

\section{Consequences for Human Development}

Moving on to the second sub-theme, Chapter 4 examines the long-term consequences of displacement by inquiring how younger generations within displaced households may fare in their particular circumstances. More specifically, outcomes arguably crucial for the healthy development of children are compared between households that have experienced internal displacement and those that have not. As a way to infer future livelihood prospects, these outcomes relate to human capital formation concentrating on both education and nutrition. The study contributes to a larger body of literature on the consequences of conflict, which routinely highlights displacement as a channel through which war may have an impact on human capital formation. Still, it is only in recent years that any empirical analysis has focused on displacement in particular, in contrast to war in general, and none in the context of Afghanistan.

In a similar line of inquiry concerning consequences, Chapter 5 considers the reintegration of return migrants into the Afghan labor market, exploring the occupational choice of returnees whose initial migration was due to conflict or general insecurity. The study is motivated by the fact that the reintegration of 
returnees greatly depends on their ability to access sustainable income-generating activities as a basis for their livelihood. The analytical approach is twofold: first, to compare non-migrants and return migrants in regards to what influences their respective occupational choices; and second, to investigate the influence of the returnees' migration and return experience on their occupational choice. The main contribution of this study is its focus on the return of those individuals whose original migration experience was due to concerns for safety, and as a result the insight concerning the labor market effect of forced migration and return. This is in contrast to the literature at large, where the attention has been on the occupational choice of returnees who originally migrated to developed countries in search of employment.

\section{Policy Response}

The final part of this dissertation reflects on a particular policy response related to conflict-related migration. Chapter 6 evaluates a shelter assistance program in Afghanistan mainly targeting returned refugees. The primary objective is to assess whether shelter assistance realizes the program's aims of improving socioeconomic conditions and strengthening the livelihood potential of beneficiary households. To this end, a multidimensional approach to poverty measurement is adopted, one based upon three principal dimensions: economic welfare, health and education, and basic services. From a practical point of view, this study provides the first judicious analysis of the largest shelter assistance program in Afghanistan, where the absence of basic shelter and land is routinely noted as a significant concern. From an academic perspective, it speaks to the literatures on refugee return, civil conflict and impact evaluation more generally.

The dissertation concludes in Chapter 7 with a brief summary of these empirical studies and their main findings. The research is then assessed in relation to certain conceptual, theoretical and empirical matters of interest, in order to identify its contribution to the greater discussion on conflict-related migration and development. Lastly, the inherent limitations of this research are discussed, followed by potential lines of future research.

In addition, it should be noted that each study was originally written and intended to be read as a self-contained article. In light of parallel themes effort has been 
made to reduce substantial overlap throughout. Nonetheless, certain similarities across chapters remain unavoidable. Moreover, all of these studies already have been published in a peer-reviewed journal or are currently under review, which is indicated at the beginning of each chapter.

\subsection{Theoretical Review}

There is no single, all-encompassing theory of migration; but this is just as well taking into consideration the multifaceted, complex nature of migration behavior and patterns across a diverse set of heterogeneous environments and moments in history (Massey et al., 1993; Castles, 2007; Bakewell, 2010). On the contrary, there is a range of theoretical work across disciplines which has advanced our understanding of migration as a fundamental social process, as well as informed and guided research on the relationship between migration and development. Indeed the association between these two phenomena has long been recognized, dating back to Ravenstein's 'laws of migration' in the late $19^{\text {th }}$ century (Skeldon, 2008). Even so, the underlying logic about the way in which migration and development interact has evolved over the years, largely mirroring more general paradigm shifts in social and development theory in the postwar era (Faist, 2008; de Haas, 2010). In light of this, the section here provides a theoretical overview which helps situate the subsequent empirical studies within a broader debate about the migration-development nexus. It concludes with a discussion about how certain fundamental approaches may help us better understand this relationship within a conflict-affected context.

\section{Deterministic Approaches to Migration and Development}

In the few decades immediately following the Second World War, migration was generally viewed in a positive light in relation to development, based mainly on the principles of modernization theory and neoclassical development economics (Goss \& Lindquist, 1995; de Haas, 2010; 2012). At its most basic, a neoclassical perspective understands migration as the result of geographic differences, either internally or internationally, in the supply of labor relative to capital. The consequent wage differential is therefore incorporated into a rational cost-benefit analysis by utility maximizing individuals, who also have information on the inherent costs of migrating as well as the expected probability of securing 
employment (Todaro, 1969; Harris \& Todaro, 1970; Massey et al., 1993; de Haas, 2010). As such, migration is explained by the economic decision-making at the individual level, but whose aggregate effect leads to a reduction in spatial inequalities (Goss \& Lindquist, 1995). Migration, then, from a neoclassical approach is thought to be part of a natural process of development based on factor price equalization between two dissimilar economies, one labor-abundant yet capital-scarce and the other labor-scarce yet capital-abundant (Lewis, 1954). Once the returns to labor and capital effectively balance out through a process of modernization, industrialization and overall economic 'catch-up' of the underdeveloped economy, the pressures to migrate are expected to subside (Lewis, 1954; Massey et al., 1993; Goss \& Lindquist, 1995; de Haas, 2010; 2012).

An important implication of the neoclassical understanding of migration and development is the role of remittances and return migration. The flip side of lowskilled workers moving towards relatively higher wages in labor-scarce economies (e.g. rich, industrialized countries) is the flow of capital towards relatively higher investment returns in capital-scarce economies (e.g. poor, agricultural countries) (Massey et al., 1993; de Haas, 2010; 2012). One part of such capital transfer is the migrants' own wages in the form of financial remittances, while another constitutes human capital in the form of return. Remittances, then, are expected to spark investment in productive enterprises back home, helping to deliver local development and contribute to rapid economic growth. Similarly, returnees are thought to bring back some of those new ideas, knowledge and attitudes picked up while abroad, which are essential for the diffusion of innovation and overall process of development (Goss \& Lindguist, 1995; Faist, 2008; de Haas, 2010; 2012).

While a neoclassical approach ascribes a certain positive narrative to the relationship between migration and development, a shift within social and development theory in the late 1960s introduced a more skeptical tone to the conversation (de Haas, 2010; 2012). From a structuralist perspective largely based on the principles of dependency and world systems theory, migration is understood as the natural product of structural underdevelopment in poorer parts of the world, following the political and economic order of an expanding global market (Massey et al., 1993; Goss \& Lindquist, 1995; Faist, 2008; de Haas, 2010). Fundamentally, unequal development across societies is a result of long-standing colonial and 
neocolonial power relations favoring rich, industrialized economies at the core of the global capitalist system. Moreover, migration from a structuralist approach is not only due to underdevelopment, but also serves as a factor that reinforces such spatial and class-based inequalities both within and across countries, thereby leading to even further migration (ibid.).

Like the neoclassical perspective, a structuralist conceptualization of migration has important implications for remittances and return migration albeit in the opposite direction. Financial remittances are assumed to rarely go towards productive investment that might potentially spark economic growth, and instead lead to conspicuous consumption, inflation and a harmful dependency on foreign cash transfers (de Haas, 2010; 2012). Similarly, the ideas, attitudes and wealth of return migrants are believed to disrupt traditional patterns of communities in the periphery, possibly resulting in an increase in the cost of living or potentially undermining local institutions (ibid.). Overall, even if such negative consequences fail to materialize, the possible benefits of remittances and return migration suggested by neoclassical theory are not expected to make up for the loss in productive value that is the result of the highly educated, experienced and ablebodied moving elsewhere (Goss \& Lindquist, 1995; Faist, 2008; de Haas, 2010; 2012).

Even though the neoclassical and structuralist approaches to migration and development appear on opposite sides of the theoretical spectrum, they share a characteristic in that they are both overly deterministic in nature. Each posits a rigid, global conceptualization of the way in which the dynamics of migration and development processes interrelate without sufficiently considering the complex and heterogeneous local circumstances that may shape a range of outcomes (de Haas, 2010; 2012). The main criticism of the neoclassical perspective, in particular, has much to do with the overemphasis on the utility maximizing ability of the individual without taking into account local structural factors that may constrain rational decision-making. On the contrary, a structuralist perspective essentially fails to provide enough attention to the inherent agency of individuals and households, even those in highly coercive environments, and arguably gives too much importance to the systematic constraints on behavior (Massey et al., 1993; de Haas, 2010; 2012). In order to move beyond these characteristic limitations of both neoclassical and structuralist approaches, there have been attempts to develop more 
integrative approaches that in principle bridge this stark division between structure and agency, and takes into account the heterogeneous nature of the relationship between migration and development.

\section{Integrative Approaches to Migration and Development}

With a turn towards a more market-friendly discourse within development thinking over much of the $1980 \mathrm{~s}$, it is of little surprise that the theoretical approaches to migration and development likewise shifted away from a structuralist perspective framed within a class-based, neo-Marxist ideology. Yet the evident limitations of the neoclassical approach necessitated a fresh conceptualization that did not discount structural inequalities, nor assume mechanistic individual behavior. The New Economics of Labor Migration (NELM) introduced a new angle to the debate by considering migration less in terms of utility maximizing behavior of the individual and more as a risk minimizing strategy of an entire family or household (Stark \& Levhari, 1982; Stark \& Bloom, 1985; Massey et al., 1993; Taylor \& Dyer, 2009; de Haas, 2010). While maintaining the importance of human agency albeit at the higher decision-making unit of the household, the NELM's focus on migration as a means to diversify an overall family portfolio provides an explanation of migration in light of market constraints and imperfections outside of just the labor market.

Because the NELM approach understands income diversification as a fundamental motive for migrating, financial remittances are an essential component to the migration-development nexus. Here, remittance transfers potentially act as a form of credit or insurance contributing to smoother household consumption in the face of high risks to external shocks and ill-functioning markets (Massey et al., 1993; Taylor, 1999; de Haas, 2010). On the other hand, remittances may be only part and parcel of an overall migration strategy in which the expected outcome is an eventual return (Constant \& Massey, 2002; Cassarino, 2004). Return migration from a NELM perspective, therefore, is the logical result of a temporary migration project in which the pre-specified objective is to transfer a certain level of income back home, either through remittance transfers while abroad or savings upon return. 
Given the NELM's roots within development thinking, it is only natural that its central notion of migration as a deliberate household strategy has noticeable similarities with a livelihoods approach to development emerging around the same period (de Haas, 2010). A livelihood generally refers to the way in which an individual or household maintains and sustains life (Jacobsen, 2002). A basic livelihoods framework takes into account not just the activities people might engage in, but also the resources, risk factors and policy context that may help or hinder them in their pursuit a viable way of life (Ellis, 2003). Migration fits within such a framework given it is understood as one of many possible ways a household might engage in new livelihood activities not available at origin, and not subject to the same risk factors or policy context. This is not to say that migration as a strategy is mutually exclusive to participating in other activities at origin, given both are in fact often combined within a single household (McDowell \& de Haan, 1997; de Haas, 2010). Only that migration as a livelihood strategy is a particularly distinct way to diversify an entire family's portfolio based on the structural differences between sending and receiving areas. Overall, a conceptualization of migration in line with the NELM and livelihood approaches seems to aptly reflect the experiences of many households in poor countries around the world, but especially those in particularly problematic environments.

\section{Migration and Development in a Conflict-affected Context}

The topic of migration within a conflict-affected setting is principally dominated by the policy-oriented discussion on refugee movements and forced migration more broadly. Forced migration, however, is all too often considered outside of the scope of conventional migration theory that by and large has been developed to explain labor migration in stable environments (Bakewell, 2007; 2010; Lindley, 2010). Indeed, migration in such a case is typically identified as anomalous behavior simply driven by violence and chaos (Bakewell \& Bonfiglio, 2013). As a result, the theoretical foundation of academic scholarship on less voluntary forms of migration is arguably lacking (Black, 2001; Castles, 2003). By recognizing this limitation in the literature as well as that there may be no satisfactory theory of forced migration that will adequately conceptualize such flows outside of a legal and descriptive framework, Black (2001, p. 66) makes the case for situating academic scholarship in this sub-field within more mainstream theories. By doing so, "such an approach would provide an opportunity to use the particular 
circumstances of refugee situations to illuminate these more general theories and thus participate in the development of social science, rather than leading refugee studies into an intellectual cul-de-sac" (ibid.).

In consideration of this suggestion, the application of a NELM and livelihoods approach to development within a conflict-affected setting seems appropriate, and has the ability to provide insight on the dynamics of potentially less voluntary forms of migration. In a context of conflict, families need to cope with both the threat to physical safety as well as to their basic means of making a living. Indeed, the undermining of peoples' livelihoods is not merely a by-product of conflict, but also routinely a deliberate consequence of war (Lautze, 1997). In the face of such risks, migration is recognized as an essential component in how countless individuals and entire families negotiate life (Lindley, 2010). As such, a NELM and livelihoods approach allows us to move beyond a simple economic interpretation of migration which fails to take into account broader aspects crucial to the understanding of migration and development in a conflict-affected setting. Just as important though, it also provides a lens with which to view conflict-related migration that is not strictly framed within a paradigm of conflict, and therefore does not discount the notion of migration as normal behavior.

Apart from providing a broader framework to assess the interaction between migration and development, one of the great strengths of the NELM and livelihoods approach is the emphasis on heterogeneity across environments. Indeed, most research over the past decades has shown this relationship to be particularly context-specific, making unqualified assumptions prior to empirical evidence ill-advised. Conflict-affected contexts face specific challenges often unlike those in settings traditionally focused upon in the migration literature including issues related to political instability, violence, systematic uncertainty and extreme deprivation, among others. In order to better understand the particular conflict-affected context under study in this dissertation, the following section provides a contextual background for the case of Afghanistan.

\subsection{Afghanistan as a Case Study}

In looking at the linkages between conflict-related migration and development, Afghanistan makes for a particularly relevant case given its experiences as of late. 
At the forefront is the prolonged period of conflict which has engulfed the country since the late 1970s. While open warfare has not been constant over this time span, the overall violence and insecurity has had grave consequences for Afghan society. Of these, one of the most significant has been the displacement of millions of individuals and families both within the country and abroad. Even though the act of migrating itself has long been part of Afghan culture in response to economic and social uncertainties and opportunities, the conflict-related migration during this time is distinct in its severity and breadth in terms of the number of people affected. While one such uncertainty is undoubtedly the level of security, another clearly has to do with the abject poverty and lack of livelihood prospects witnessed in many parts of the country. With this in mind, this section briefly provides more contextual information regarding the Afghan setting as it pertains to the political instability, conflict and accompanying migration trends over the last four decades, along with the corresponding state of human development in order to provide a clear backdrop for the empirical studies that follow.

\section{Political Instability, Conflict and Migration Trends}

It is commonly understood that the current period of conflict in Afghanistan began with the 1978 coup d'état by the communist People's Democratic Party of Afghanistan (PDPA). While certainly accurate, less recognized is the fact that the political crisis at that time had its origins in the fall of the monarchy, and with it its experiment with democracy, some five years earlier (Griffiths, 2011). This marked the end of a half century of relative peace and internal stability enjoyed by Afghanistan. From this point on, in the eyes of the ordinary Afghan the political legitimacy of each ruling power was weaker than the last, increasingly resulting in the use of force in order to maintain authority (Barfield, 2010, p. 164).

The 1978 takeover by the PDPA precipitated nearly a decade of Soviet occupation in support of the Afghan regime up against a Islamist-led, CIA-backed mujahedeen resistance movement. Fighting between Soviet forces and the armed rebellion took an incredibly heavy toll on Afghan society. The war contributed to a huge number of civilian losses throughout the country and forced millions more into displacement (Turton \& Marsden, 2002; Jazayery, 2002; Monsutti, 2008). While migration during this time was not an entirely new occurrence for many due to the long Afghan history of migratory movements, it did mark a more cataclysmic event 
than anything that came before it (Monsutti, 2006; Kronenfeld, 2008). Within the first year of the Soviet's arrival nearly two million individuals had fled the country, and more than five million by 1985 (UNHCR, 2015a). Not surprisingly, the majority of these people went to neighboring Pakistan and Iran, with the former thought to have received almost 2.5 million over the entire decade (CSSR, 2006). Moreover, many families without the means or desire to cross national borders, yet still incapable of remaining in their communities of origin fled within Afghanistan. Even though official statistics are lacking, it is believed there were some two million IDPs around this period (Kuschminder \& Dora, 2009). Despite the Soviet's retreat in 1989, out-migration continued in the following years due to the increasingly violent fighting between rival mujahedeen groups and government forces attempting to hold on to power. Between 1990 and 1991, the official refugee count peaked above 6.3 million (UNHCR, 2015a).

The eventual fall of the Afghan government in 1992 failed to ease the conflict, and instead sparked an intense power struggle between vying mujahedeen factions divided along sectarian and ethnic lines. Fighting between groups mostly took place in the streets of Kabul, however the lack of central authority also allowed regional warlords to plunder and pillage throughout the countryside in an attempt to gain resources needed to fund military activities (Barfield, 2010). Even so, Afghanistan experienced a massive inflow of returning refugees around this time with more than half of those abroad repatriating within two years (UNHCR, 2015a). Yet it also triggered a new outflow of mostly educated, middle class families from urban areas. As such, the trend during this short interval can be characterized by its fluidity as many individuals returned but a substantial amount also left or decided to remain abroad depending on the local situation (Jazayery, 2002; Turton \& Marsden, 2002; Stigter, 2006; Kuschminder \& Dora, 2009).

The grim situation over the next few years, characterized by overall insecurity and a general lack of control, led to the rise of the Taliban. With the intent of bringing order and supplying fundamentalist justice in the name of Islam, the Taliban quickly gained power and took control of Kabul by 1996 and most of the rest of the country by 1999 (Griffiths, 2011). In light of their harsh imposition of Shari'a law, much of the return flows up until that point came to a halt, and further outmigration resulted especially by certain minority groups like the Hazara. Moreover, a severe drought towards the end of the decade caused a new stream of 
displacement as many families were suddenly unable to survive off their land (Jazayery, 2002; Turton \& Marsden, 2002). By the turn of the century, the number of Afghan refugees had increased back to 3.5 million with another 750,000 estimated as internally displaced (UNHCR, 2015a).

The Taliban's infamously brutal hold on power, however, did not last long. As a result of the al Qaeda attacks on New York City and Washington, DC on September 11, 2001, the United States and coalition forces, along with anti-Taliban groups within Afghanistan, launched a decisive campaign which saw the Taliban leadership unseated by year's end. During this time the number of Afghans leaving the country briefly increased as many families fled either in anticipation of or in response to the US-led offensive. However, as indicated in Figure 2 the removal of Taliban government kicked off an enormous repatriation effort, especially from Pakistan and Iran.

With support by the international community, around two million refugees voluntarily returned in 2002 alone, and another two million are believed to have made their way back by 2005 (UNHCR, 2015a). While these official estimates have been put into doubt taking into consideration the monumental challenge of keeping track of fluid migratory flows especially in light of notoriously porous borders, by any measure the number of Afghan refugees returning during this period was sizeable (Kronenfeld, 2008). In addition, nearly a million IDPs also returned to their communities of origin at the same time (UNHCR, 2015a).

In the early years of the post-Taliban era the central focus had been to rebuild a competent Afghan government along with establishing the security and economic development everyday Afghans had come to expect. To do so, the Karzai-led government was forced to rely heavily on international support given its own limitations. The international community, therefore, has maintained a heavy presence in the country since 2002, supporting not only the security efforts through military means but also providing substantial development and humanitarian assistance throughout the country. While such assistance has surely benefited parts of the population, on the whole they have failed to provide widespread security or substantially improve one of the lowest living standards in the world (UNDP, 2014). Moreover, the reappearance of the Taliban around 2006 has resulted in a subsequent escalation of attacks in parts of the country leading to further 
displacement. Since then the total number of refugees has increased to somewhere between 2.5 and 3 million, while the number of IDPs has risen to more than 800,000 . Correspondingly, the number of refugee and IDP returnees has declined considerably, with the most recent estimates for both around 20,000 (UNHCR, 2015a). While much of this trend is surely a direct result of the Taliban resurgence, a large part is also likely due to the low living conditions and relatively limited opportunities to make an honest living in many parts of the country, as well as the substantial uncertainty about the coming years.

Figure 2: Migration patterns in Afghanistan since 2000



Source: UNHCR (2015a). The number of 'Refugees' and 'IDPs' indicates the stock of the population either from or within Afghanistan, respectively, while the number of 'Returned Refugees' and 'Returned IDPs' indicates flows within the calendar year (i.e. January December). No official data is available for 'Returned IDPs' prior to 2002. More generally, population data in Afghanistan including the number of individuals crossing borders is questionable (see, e.g., Kronenfeld, 2008), and as such should be considered with caution.

At present, Afghanistan lies at another defining moment in its history. The country celebrated its first democratic transfer of power in 2014, with Ashraf Ghani officially being named president. It is still too early to tell the mandate and perceived legitimacy that the newly formed Afghan government will enjoy, but this will ultimately influence its ability to enact lasting change. Moreover, the long- 
scheduled transfer of responsibility for security throughout the country has proceeded with international combat operations officially ending in 2014. As a result, the majority of international troops have withdrawn as planned with those remaining focused mainly on advising, training and assisting Afghan security forces. Prior to a complete withdrawal planned for 2016, it remains to be seen whether Afghan forces are able to not only withstand but also beat back a rising insurgency that is everyday more brazen in their attacks. With the years of violent conflict still fresh in the memory, it should come as little surprise that many Afghans entertain the idea of preemptively moving in anticipation of further unrest. At the very least, with much of the country and outside world in a wait and see mode, many Afghans who would have likely returned both from abroad and internally by now may be staying put to see how recent events unfold in the near future.

\section{State of Human Development}

Unsurprisingly the nearly four decades of intermittent conflict has taken a great toll on the state of human development in Afghanistan. Aside from the devastating loss of life and massive displacement, war has led to the destruction of homes, the loss of jobs, the forfeiture of assets and the overall deterioration of basic living conditions. While those efforts by the government and international community since 2002 have helped improve the situation in certain thematic areas of importance, there still remain many challenges for everyday Afghans. In order to illustrate a more detailed account of general well-being, the following highlights relevant statistical information from the most up-to-date National Risk and Vulnerability Assessment (NRVA) for 2011/2012 published by the Central Statistics Office (CSO) of Afghanistan in 2014. The NRVA is the only survey available that is believed to be nationally representative which provides a comprehensive profile of the country, given no internationally verified census of the Afghan population has taken place since 1979 (Hanifi, 2006).

Generally speaking, Afghanistan has experienced little progress over the years in regards to poverty. Practically unchanged since its last publication four years prior, the NRVA finds that nearly 10 million individuals, or 37 percent of the Afghan 
population, lives below the national poverty line based on a minimum level of consumption $^{3}$ (CSO, 2014, p. 45). Still, notable differences exist between the type of district as well as across regions. Rural households, for instance, are significantly more likely to fall below the poverty line relative to urban households, 38 percent vs. 29 percent, while the nomadic Kuchi population has the highest incidence of poverty at 54 percent (id., p. 46). Similarly, just under a third of the entire Afghan population, or 27 million people, is estimated to be food insecure, meaning their kilocalorie intake is less than 2,100 per day. Moreover the quality of diet of the Afghan population is considered poor and heavily cereal-based, with nearly one in five not consuming an adequate level of protein. Such food insecurity is particularly worrisome for children under-five who face a high risk of malnutrition (id., p. 51).

Corresponding to the pervasive nature of poverty and food insecurity, much of the Afghan population lives in poor housing conditions. Only 14 percent reside in structures considered durable based on the material used for construction, while another 37 percent live in an overcrowded dwelling (id., p. 84-85). The growth of slums is also a challenge around most urban centers, especially Kabul, with 87 percent of urban residents living in slum-like conditions (id., p. 85). Moreover, there is a widespread lack of basic infrastructure for water and sanitation, with 46 percent of all households using improved drinking water sources and only 8 percent using improved sanitation facilities. Still, this has been an improvement from just four years prior, when only 27 and 5 percent of households used each, respectively (id., p. 86-87).

In regards to education and health, the NRVA indicates relative progress. Even though Afghanistan remains one of the poorest performers in providing adequate education, it made significant gains in terms of overall primary and secondary school attendance. Specifically, the net primary school ratios for boys and girls jumped to 64 and 48 percent respectively, up from 43 and 29 percent just eight

\footnotetext{
${ }^{3}$ The national average poverty threshold of 1,255 AFS per person per month used in the NRVA is calculated on the basis of a monetary value of a basket of goods and services an individual needs to sustain a minimum level of material well-being, including the typical cost of attaining 2,100 calories per person per day and of meeting some basic non-food needs.
} 
years prior (id., p. 62). A similar trend exists for secondary school, albeit at a lower level. Still, the large differences between boys and girls, as well as those between urban and rural settings, are of key concern looking forward. For health, it seems the greatest improvement relates to the access to health services in light of an extensive outreach program by the corresponding ministry, as well as a rise in private health facilities across the country (id., p. 73). Nonetheless, the cost of health care especially among poorer households, along with cultural issues surrounding the ability of women to seek assistance outside the home, seems to remain a serious obstacle to further progress in health provision.

Lastly, the highly informal economy in Afghanistan resulting in a weak formal labor market prohibits many households from maintaining a sustainable livelihood. Moreover, there are stark differences between male and female labor participation rates, with males four times more likely to be engaged in work. Even though most male Afghans able to work are active in the labor market out of necessity, resulting in a misleadingly low unemployment rate, the lack of decent and productive jobs causes many to take on multiple low-paid activities in order to provide a sufficient income. More than four out of five employed Afghans engage in so-called vulnerable employment which includes day labor, own-account work and unpaid family work (id., p. 32). Much of this reflects the importance of the agricultural sector in Afghanistan, where around 40 percent of the working population is engaged in farming or livestock rearing (id., p. 35). Furthermore, such reliance of so many households on agricultural activities indicates the high degree of exposure many Afghans face to the risk of water shortages and land infertility.

All in all, the Afghan case provides a particularly relevant contextual backdrop to investigate the link between conflict-related migration and development. The political instability and persistent conflict has caused it to become for many years the place of origin for the largest population of refugees in the world. At the same time it has experienced some of the highest rates of internal displacement, and greatest return flows at various periods over the decades. Likewise, it is little surprise that the country has suffered from some of the worst levels of human development on the planet. The way in which such contextual characteristics are taken into account in practice is detailed in the next section when describing the specific datasets used within this research. 


\subsection{Datasets}

As already indicated, the various essays that make up this dissertation are empirical in nature and based on a quantitative research design. In particular, econometric regression analysis is employed throughout with specific methods detailed within their respective chapters. Figure 3 illustrates how all studies rely on one of two unique micro-level datasets originating from household surveys collected in Afghanistan in 2011 and 2012. Due to fundamental limitations in conducting fieldwork in high-risk areas of the country, along with the unavailability of up-todate administrative data in certain locations, in neither survey was a purely random sampling methodology able to be employed. Both, therefore, should not be considered nationally-representative. Even so, great lengths were taken in both surveys to sample households of differing fundamental characteristics - for example based on ethnicity, socio-economic status and migration profile - in order to increase overall representativeness as is detailed below.

Figure 3: Dataset per chapter

\begin{tabular}{|l|c|c|c|c|c|}
\hline & Chapter 2 & Chapter 3 & Chapter 4 & Chapter 5 & Chapter 6 \\
\hline IS Academy Dataset & $\checkmark$ & $\checkmark$ & & $\checkmark$ & \\
\hline UNHCR Dataset & & & $\checkmark$ & & $\checkmark$ \\
\hline
\end{tabular}

\section{IS Academy Dataset}

The first household survey was collected in the second quarter of 2011 as part of the IS Academy 'Migration and Development: a World in Motion' project, which was financially supported by both the Dutch Ministry of Foreign Affairs and the International Organization for Migration. ${ }^{4}$ The Maastricht Graduate School of Governance was in charge of the IS Academy project's data collection in Afghanistan which was implemented in the field by Samuel Hall Consulting. The survey was developed as a way to explore a diverse set of themes related to the relationship between migration and development processes. As such, a range of

\footnotetext{
4 For more information, see: http://migration.merit.unu.edu/research/projects/is-academy-onmigration-and-development-migration-a-world-in-motion-2009-2013/.
} 
thematic modules within the survey aimed to capture in-depth information at the individual- and household-level including overall socio-economic characteristics, migration histories, future migration plans, remittance behavior, shocks, and much more.

In terms of sampling methodology, the five provinces of Kabul, Herat, Balkh, Nangarhar and Kandahar were selected because of their highly populated urban centers, geographical dispersion and varied profiles of migration. Within each province, a stratification of districts was applied based on whether they were considered urban, semi-rural or rural. ${ }^{5}$ This stratification allowed for greater representation of different socio-economic groups, and districts were chosen based on their representativeness of the province at large. The primary sampling units were then selected at random taking into consideration a detailed list of specific sites for enumeration provided by the Afghan Central Statistics Office. In all, ten communities within an urban area and five from each of the semi-rural and rural areas were selected for enumeration. Within the communities, the absence of any official household listing made it necessary for the team leader to discuss the rough makeup of the community with a local leader or elder prior to enumeration. This led to a general distributional profile of the community based on current migrant, return migrant and non-migrant households which was then respected throughout enumeration in order to be as representative as possible. Finally, the selection of households followed a random starting point and fixed interval sampling strategy in order to meet the pre-specified quota in each community. Ultimately, the survey covered a total 14,777 individuals within 2,005 households across 100 distinct communities.

\section{UNHCR Dataset}

The second household survey was collected in late 2012 as part of an independent evaluation of the UNHCR shelter assistance program. ${ }^{6}$ Like the IS Academy

\footnotetext{
${ }^{5}$ Urban refers to those communities which are the district capital; semi-rural refers to those communities which share a common border with the district capital; and rural refers to those communities with no common border with the district capital.

${ }^{6}$ For more information, see: http://migration.merit.unu.edu/research/projects/unhcr-shelter-assistanceevaluation-afghanistan-2012-2013/.
} 
project, the Maastricht Graduate School of Governance organized the data collection which was again carried out by Samuel Hall Consulting in the field. However, given the aim of the survey was to independently assess the impact and relevance of a specific program, the household survey by design was inherently more limited in scope in comparison to that from the IS Academy project. In particular, the survey was developed not only to gauge the contribution of shelter assistance to reintegration of returnees within their communities, but also to appraise the program design and effectiveness based on beneficiary experiences as well as relevance and sustainability within the broader context of humanitarian assistance in Afghanistan. Overall, a range of detailed information was captured by the survey at the household-level including again socio-economic situation, migration history, experience with assistance programs including naturally shelter assistance, and much more.

Since the focus of the evaluation was on UNHCR operations, sampling reflects the general distribution of their activity in areas known to have high levels of return migration. In total 15 provinces, at least one in each of the country's eight regions, were selected with consideration for the presence of shelter assistance beneficiary households, while also taking into account local security restrictions. Within provinces, one or more districts were selected for cluster sampling again based on the presence of beneficiary households and security conditions. The primary sampling units, villages in rural areas and neighborhoods in urban areas, were then randomly selected in light of a general record of beneficiary locations provided by UNHCR and their implementing partners. Within these communities, both beneficiary and non-beneficiary households were surveyed at random when possible. Due to the geographic dispersion of beneficiary households in certain communities, the teams were at times forced to rely on a list of beneficiaries and snowball strategy to meet a targeted number of households. Ultimately, the survey covered a total 4,548 households across 60 communities.

All things considered, these two detailed surveys provide a unique opportunity to empirically explore the link between conflict-related migration and development in the case of Afghanistan. This prospect is particularly valuable considering the fact that data from such a characteristically high-risk environment is typically limited in availability. Moreover and as highlighted prior, taking advantage of both datasets 
allows for a comprehensive look not only at migration across national borders, but also internal displacement and return migration.

\subsection{Concluding Remarks}

This opening chapter has introduced the discussion around the relationship between conflict-related migration and development, the underlying topic with which this dissertation is concerned taking into consideration the (post-) conflict context of Afghanistan. Aside from presenting a brief outline of the research found in Chapters 2 through 6 , the principal aim has been to situate these varied empirical studies within a coherent conceptual and theoretical framework. Additionally, the relevant contextual features of Afghanistan have been detailed, along with the datasets relied on for the analyses. Ultimately, these conceptual and theoretical issues highlighted here will be revisited in the concluding chapter. A critical assessment at that point will make clear the contribution of the dissertation as a whole to the overall field of knowledge concerning migration and development, and will likewise point towards future lines of inquiry that may be of particular interest. 


\section{Works Cited}

Alkire, S., \& Santos, M. E. (2014). Measuring Acute Poverty in the Developing World: Robustness and Scope of Multidimensional Poverty Index. World Development, 59, 251 - 274.

Bakewell, O. (2007). Researching Refugees: Lessons from the Past, Current Challenges and Future Directions. Refugee Survey Quarterly, 26(3), 6 - 14.

Bakewell, O. (2009). South-South Migration and Human Development: Reflections on African Experiences. (Human Development Research Paper 2009/07). UNDP.

Bakewell, O. (2010). Some Reflections on Structure and Agency in Migration Theory. Journal of Ethnic and Migration Studies, 36(10), 1689 - 1708.

Bakewell, O., \& Bonfiglio, A. (2013). Moving Beyond Conflict: Re-framing mobility in the African Great Lakes region. (IMI Working Paper 71). International Migration Institute, University of Oxford.

Bakewell, O. (2015). Migration makes the Sustainable Development Goals agenda - time to celebrate? News, Opinion. Oxford Martin School, University of Oxford. Retrieved December 20, 2015, from $<$ http://www.oxfordmartin.ox.ac.uk/opinion/view/315>.

Barfield, T. J. (2010). Afghanistan: a cultural and political history. Princeton: Princeton University Press.

Black, R. (2001). Fifty Years of Refugee Studies: From Theory to Policy. International Migration Review, 35(1), 57 - 78.

Cassarino, J. P. (2004). Theorising return migration: The conceptual approach to return migrants revisited. International Journal of Multicultural Societies, $6(2), 253-279$.

Castles, S. (2003). Towards a Sociology of Forced Migration and Social Transformation. Sociology, 37(1), 13 - 34.

Castles, S. (2007). Twenty-First-Century Migration as a Challenge to Sociology. Journal of Ethnic and Migration Studies, 33(3), 351 - 371.

Castle, S., de Haas, H., \& Miller, M. (2013). Age of Migration: International Population Movements in the Modern World. New York: Guilford Press.

Central Statistics Office (CSO). (2014). National Risk and Vulnerability Assessment 2011/2012. Afghanistan Living Conditions Survey. Kabul: Central Statistics Office. 
Clemens, M. A., Özden, C., \& Rapaport H. (2014). Migration and Development Research is Moving Far Beyond Remittances. World Development, 64, 121 $-124$.

Collective for Social Science Research (CSSR). (2006). Afghans in Pakistan: Broadening the Focus. (AREU Briefing Paper). Afghanistan Research and Evaluations Unit (AREU).

Constant, A., \& Massey, D. S. (2002). Return Migration by German Guestworkers: Neoclassical versus New Economic Theories. International Migration, 40(4), 5 - 38.

Czaika, M. (2009). The Political Economy of Refugee Migration. (Discussion Paper Series Nr. 7). Department of International Economic Policy, University of Freiburg.

Czaika, M., \& de Haas, H. (2014). The Globalization of Migration: Has the World Become More Migratory? International Migration Review, 48(2), 283 323.

de Haas, H. (2009). Mobility and Human Development. (Human Development Research Paper 2009/01). UNDP.

de Haas, H. (2010). Migration and Development: A Theoretical Perspective. International Migration Review, 44(1), 227 - 264.

de Haas, H. (2011). The determinants of international migration: conceptualising policy, origin and destination effects. (Working Paper 32). International Migration Institute, University of Oxford.

de Haas, H. (2012). The Migration and Development Pendulum: A Critical View on Research and Policy. International Migration, 50(3), 8 - 25.

de Haas, H. (2014). Migration Theory: Quo Vadis? (Working Paper 100). International Migration Institute, University of Oxford.

Dreze, J., \& Sen, A. (2013). Uncertain Glory: India and its Contradictions. Allen Lane.

Ellis, F. (2003). A Livelihoods Approach to Migration and Poverty Reduction. (Paper commissioned by the Department for International Development). DFID.

Faist, T. (2008). Migrants as Transnational Development Agents: An Inquiry into the Newest Round of the Migration-Development Nexus. Population, Space and Place, 14, 21 - 42. 
Goldin, I., Cameron, G., \& Balarajan, M. (2012). Exceptional People: How Migration Shaped Our World and Will Define Our Future. Princeton: Princeton University Press.

Goss, J., \& Lindquist, B. (1995). Conceptualizing International Labor Migration: A Structuration Perspective. International Migration Review, 29(2), 317 351.

Griffiths, J. C. (2011). Afghanistan: Land of Conflict and Beauty. London: Andre Deutsch.

Hanifi, S. M. (2006). Material and Social Remittances to Afghanistan. In C. Westcott \& J. Brinkerhoff, Converting Migration Drains into Gains: Harnessing the Resources of Oversees Professionals. Manila: Asian Development Bank.

Harris, J. R., \& Todaro, M. P. (1970). Migration, Unemployment and Development: A Two-Sector Analysis. American Economic Review, 60, $126-142$.

Hugo, G., Abbasi-Shavazi, M. J., \& Sadeghi, R. (2012). Refugee movement and development: Afghan refugees in Iran. Migration and Development, 1(2), $261-279$.

Hujo, K., \& Piper, N. (2007). South-South Migration: Challenges for development and social policy. Development, 00, 1 - 7.

Internal Displacement Monitoring Centre (IDMC). (2015). Global figures. Retrieved August 1, 2015, from <www.internal-displacement.org>.

Jacobsen, K. (2002). Livelihoods in Conflict: The Pursuit of Livelihoods by Refugees and the Impact on Human Security of Host Communities. International Migration, 40(5), 95 - 123.

Jazayery, L. (2002). The Migration-Development Nexus: Afghanistan Case Study. International Migration, 40(5), 231 - 254.

King, R. (2012). Theories and Typologies of Migration: An Overview and A Primer. (Willy Brandt Series of Working Papers in International Migration and Ethnic Relations 3/12). Malmo Institute for Studies of Migration, Diversity and Welare (MIM), Malmo University.

Koser, K., \& Martin, S. (2011). The Migration-Displacement Nexus. In K. Koser, \& S. Martin (Eds.), The Migration-Displacement Nexus: Patterns, Processes, and Policies. New York: Berghahn Books. 
Kronenfeld, D. A. (2008). Afghan Refugees in Pakistan: Not All Refugees, Not Always in Pakistan, Not Necessarily Afghan? Journal of Refugee Studies, 21(1), $43-63$.

Kuschminder, K., \& Dora, M. (2009). Migration in Afghanistan: History, Current Trends and Future Prospects. (MGSoG Paper Series). Migration and

Development Country Profiles. Maastricht Graduate School of Governance.

Lautze, S. (1997). Saving Lives and Livelihoods: The Fundamentals of a Livelihood Strategy. Feintein International Famine Centre, Tufts University.

Lewis, W. A. (1954). Economic Development With Unlimited Supplies of Labour. Manchester School, 22, 139 - 191.

Lindley, A. (2010). Leaving Mogadishu: Towards a Sociology of Conflict-Related Mobility. Journal of Refugee Studies, 23(1), 2 - 22.

Massey, D. S., Arange, J., Hugo, G., Kouaouci, A., Pelligrino, A., \& Taylor, J. E. (1993). Theories of international migration: A review and appraisal. Population and Development Review, 19, 431 - 466.

McDowell, C., \& de Haan, A. (1997). Migration and Sustainable Livelihoods: A Critical Review of the Literature. (IDS Working Paper 65). Institute of Development Studies, University of Sussex.

Monsutti, A. (2006). Afghan Transational Networks: Looking Beyond Repatriation. (Synthesis Paper Series). Afghanistan Research and Evaluation Unit (AREU).

Monsutti, A. (2008). Afghan Migratory Strategies and the Three Solutions to the Refugee Problem. Refugee Survey Quarterly, 27(1), 58 - 73.

Ratha, D., \& Shaw, W. (2007). South-South Migration and Remittances. (World Bank Working Paper no. 102). World Bank.

Sen, A. (1999). Development as Freedom. New York: Oxford University Press.

Sen, A. (2000). A Decade of Human Development. Journal of Human Development and Capabilities, 1(1), 17 - 23.

Skeldon, R. (2008). International Migration as a Tool in Development: A Passing Phase? Population and Development Review, 34(1), 1 - 18.

Skeldon, R. (2015). What's in a title? The fifth edition of the Age of Migration. Ethnic and Racial Studies, 38(13), 2356 - 2361.

Stark, O., \& Bloom, D. E. (1985). The New Economics of Labor Migration. American Economic Review, 75(2), 173 - 178. 
Stark, O., \& Levhari, D. (1982). On Migration and Risk in LDCs. Economic Development and Cultural Change, 31(1), 191 - 196.

Stigter, E. (2006). Afghan Migratory Strategies - An Assessment of Repatriation and Sustainable Return in Response to the Convention Plus. Refugee Survey Quarterly, 25(2), 109 - 122.

Sumner, A. (2008). What is 'Development'? In A. Sumner, \& M. A. Tribe, International Development Studies: Theories and Methods in Research and Practice. London: Sage.

Taylor, J. (1999). The New Economies of Labour Migration and the Role of Remittances in the Migration Process. International Migration, 37(1), 63 88.

Taylor, J. E., \& Dyer, G. A. (2009). Migration and the Sending Economy: A Disaggregated Rural Economy-Wide Analysis. Journal of Development Studies, 45(6), 966 - 989.

Todaro, M. P. (1969). A model of migration and urban unemployment in lessdeveloped countries. American Economic Review, 138 - 148.

Turton, D. (2003). Conceptualizing Forced Migration. (RSC Working Paper). Refugee Studies Centre, University of Oxford.

Turton, D., \& Marsden, P. (2002). Taking Refugees for a Ride? The Politics of Refugee Return to Afghanistan. (Issue Paper Series). Afghanistan Research and Evaluations Unit (AREU).

ul Haq, M. (1995). The Advent of the Human Development Report. In M. ul Haq, Reflections on Human Development . New York: Oxford University Press.

United Nations Department for Economic and Social Affairs (UNDESA). (2013). International Migration Report 2013. New York: UNDESA.

United Nations Development Programme (UNDP). (2010). Human Development Report 2010: Real Wealth of Nations, Pathways to Human Development. New York: UNDP.

United Nations High Commissioner for Refugees (UNHCR). (2015a). UNHCR Statistical Online Population Database. Retrieved September 1, 2015, from $<$ www.unhcr.org/statistics/populationdatabase $>$.

United Nations High Commissioner for Refugees (UNHCR). (2015b). 2015 likely to break records for forced displacement - study. Retrieved December 20, 2015, from < http://www.unhcr.org/5672c2576.html>.

United Nations High Commisioner for Refugees (UNHCR). (2016). Global Trends: Forced Displacement in 2015. Geneva: UNHCR. 
Chapter 1

Van Hear, N., Brubaker, R., \& Bessa, T. (2009). Managing Mobility for Human Development: The Growing Salience of Mixed Migration. (Human Development Research Paper 2009/20). UNDP.

Williams, N. E. (2013). How community organizations moderate the effect of armed conflict on migration in Nepal. Population Studies, 67(3), 353 - 369. 


\section{Chapter 2}

\section{The Influence of Vulnerability on Migration Intentions $^{7}$}

\subsection{Introduction}

This study explores the micro-level determinants of migration in Afghanistan. Contrary to the bulk of academic work which takes a revealed preferences approach and looks exclusively at migration behavior, our analysis takes into consideration stated preferences utilizing migration intentions. The reasons are two-fold: first, our data allows for a more robust analysis of intentions rather than behavior and second, migration intentions are not likely plagued by an endogeneity problem as is migration behavior allowing for greater causal inference. While there may be instinctive doubt as to whether intentions approximate actual behavior, a growing body of literature suggests plans to migrate are in fact a good, albeit imperfect, predictor of future migration behavior (Gardner et al., 1985; de Jong, 2000; Van Dalen \& Henkens, 2008; Creighton, 2013). Nonetheless, our goal is not to argue whether intentions do robustly predict actual migration behavior, but to investigate the drivers of those intentions in their own right.

The reasons why an individual chooses to migrate are wide-ranging and cut across a broad spectrum of economic, social, cultural and political lines of explanation. Traditionally, movement has been understood to be caused by differences between locales in certain economic-related factors including employment and wages. In an insecure environment much like Afghanistan, however, where there exists a particularly fine line between voluntary and forced migration, it seems sensible to avoid presupposing migration is strictly economic in nature. With this in mind, we consider the issue through the broader lens of household vulnerability, a measure

\footnotetext{
${ }^{7}$ This chapter is based on: Loschmann, C. \& Siegel, M. (2014). The influence of vulnerability on migration intentions in Afghanistan. Migration and Development, 3(1), 142 - 162.
} 
which incorporates a range of socio-economic factors allowing for a more comprehensive analysis.

In our model, vulnerability is the result of two factors: the high uncertainty of a detrimental shock occurring, and the low resilience to cope if that shock happens to materialize. Therefore vulnerability is caused by the combination of exposure to risk (high uncertainty) and lack of entitlements (low resilience). We follow the conceptual framework put forth by Ahmed and Gassmann (2009; 2010) which understands vulnerability in a post-conflict setting to be caused by functioning losses within four principal dimensions: (1) human security; (2) exchange freedom; (3) social capital and (4) access. By classifying losses along these four dimensions, we are able to identify specific indicators within each allowing for measurement.

With this conceptual and practical framework at hand, the research question to be answered is: does vulnerability influence migration intentions, and more specifically which vulnerability-related factors are associated with concrete plans to migrate abroad? The analysis therefore is a two-step process. We first profile household vulnerability using individual indicators of deprivation defined along four dimensions both in a dimensional and multidimensional fashion, and then introduce a regression analysis estimating the influence on migration intentions.

Afghanistan makes for an interesting case study for any number of reasons, but particularly due to the migration-related trends over the last decade and a half. Prior to the fall of the Taliban in 2001, a substantial portion of the Afghan population resided abroad as refugees, mostly in neighboring Pakistan and Iran. Since then, however, the country has witnessed a massive return from abroad, 5.7 million people by UNHCR's (2015) accounts, due in part to the perception that support from the international community would foster in an era of enhanced security as well as a more robust political and economic environment. While progress has been made in certain aspects of everyday life, overall vulnerability remains stubbornly high. The most recent National Risk and Vulnerability Assessment (NRVA) for 2011/2012, for example, estimates close to 10 million people, or 37 percent of the population, living in absolute poverty without the ability to meet his or her basic needs (CSO, 2014). Add to this picture the withdrawal of foreign troops from the country and it should come as no surprise 
that many Afghans, including those who have only recently returned, once again entertain the possibility of moving abroad.

The remainder of this chapter is structured as follows. We begin with a brief theoretical review pertinent to the way in which we understand the determinants of migration from an insecure setting. We next provide a working definition of vulnerability and an outline of our measurement criteria used in the model. This is followed by a description of the empirical model along with an overview of the sample. We then present both descriptive and empirical results, before concluding.

\section{$2.2 \quad$ Theoretical Approach}

Academic study on the causes of migration has blossomed over the years, helping to paint a more nuanced picture as to why an individual may want and/or decide to move both within and across borders. Traditionally, migration theory has been highly influenced by neoclassical economic thought including the standard pushpull model. The more contemporary New Economics of Labor Migration (NELM) approach, however, developed over the last 30 odd years, has made up for some of the inherent limitations embedded within the neoclassical perspective as was described in the previous chapter. Incorporating many of the fundamental concepts from the livelihoods approach common in development studies, the NELM perspective offers a more comprehensive explanation as to why certain individuals aspire to migrate.

The NELM approach rests on the assumption that the decision to migrate is not always considered merely by the individual, but rather often within a larger social context of typically the household or greater family. Migration, therefore, is driven by a collective effort to not just maximize income, but also minimize risks to income generation (Stark \& Bloom, 1985; Taylor \& Dyer, 2009; de Haas, 2010a). As such, migration is viewed as a means by which the household is able to increase capital assets, diversify sources of income and provide income insurance in environments characterized by highly imperfect markets. An important implication of the NELM approach is that the 'poorest of the poor' are generally restricted from moving given they are unable to assume the costs and risks inherent in leaving ones' home. Moreover, in contrast to the neoclassical perspective, overall socio-economic development is likely to lead to increased movement at least in the 
medium term, creating what some authors have dubbed a 'migration hump' due to individuals having both higher capabilities and aspirations to migrate abroad (de Haas, 2010b).

As discussed earlier, there exist noticeable similarities between the NELM perspective and livelihoods approach to development. In essence, livelihood strategies are the range of decisions households explicitly make in order to meet unique priorities, which commonly consist of maintaining, securing and improving the living condition of the household. Migration of a household member, especially when considering the expectation of remittance transfers, is one such possible strategy helping to diversify income sources and overcome social, economic and institutional development barriers (de Haas, 2010a). The NELM perspective embedded with the livelihoods approach to development allows for a richer explanation of the micro-level motivations of migration. The individual agency of the migration process is taken into account as households explicitly strategize to improve well-being, yet not at the expense of ignoring the importance of the local contextual environment including the structural constraints to development. As Kothari (2002, p. 10) highlights, "it is the complex interaction, rather than opposition, of individual agency and macro structures within an historical context which provides a more useful framework for understanding why people migrate".

One factor directly linking individual agency and the structural constraints to development is pervasive deprivation. While poverty has long been integrated into the equation concerning why certain individuals may wish or decide to migrate, more often than not the focus has been exclusively on monetary indicators of poverty like low income. This monetary focus has corresponded to the narrow attention on voluntary forms of labor migration, while disregarding so-called involuntary migration by refugees and asylum-seekers where deprivation may not be solely due to low income. In an environment where any classification in terms of the type of migration is problematic because underlying causes blend, be they economic, political or humanitarian, it is useful to take a broader perspective. With this in mind, de Haas (2009, p. 2-3) rightly points out, "it is important to emphasise that all migrants face structural constraints and that the degree to which they can exercise agency is fundamentally limited...it is therefore probably more appropriate to conceive of a continuum running from low to high constraints under which migration occurs." 
In light of this notion, and taking into consideration the insecure environment characterizing Afghanistan, we choose to inspect the aspirations to migrate based on household vulnerability. To the best of our knowledge the explicit way vulnerability influences migration has not been looked at prior. Still, this seems only a small, logical step stemming from an NELM and livelihoods approach, with vulnerable households in a context deficient in social protection possibly aspiring to apply an informal coping strategy like migration. Still, because migration abroad inherently incorporates high costs and risks, we expect as the NELM narrative hypothesizes that the 'most vulnerable of the vulnerable' have low capability and therefore realistic aspirations for such cross-border movement.

\subsection{Methodology}

\section{Definition and Measure of Vulnerability}

In order to explore how migration is related to vulnerability, we first present a workable definition. The literature on vulnerability stems from the seminal work of authors like Sen (1981; 1999), Chambers (1989) and Jodha (1988), each making a concerted effort to re-conceptualize the notion of poverty as more than the conventional lack of income. Despite the obvious similarities between poverty and vulnerability, the two concepts are not synonymous. While poverty can be thought of as the deprivation of different indicators like income, consumption, health, education and the like, vulnerability is better understood as the uncertainty caused by deprivation across those different indicators. Thus, poverty is a static condition at a moment in time, while vulnerability is a dynamic condition related to the insecurity about the future (Moser, 1998). Typically an individual or household is deemed to be vulnerable if at risk of falling into poverty at some future period. Vulnerability, therefore, is intrinsically related to the risks individuals and households face, and the manifestation of those risks as shocks materialize.

From the outset, we are able to conceptually disaggregate vulnerability into two distinct components: the internal and the external (Chambers, 1989). The internal side of vulnerability pertains to the idiosyncratic risks faced by particular groups of individuals or households due to weak risk management and low coping ability once faced with a shock (Prowse, 2003). Examples of possible factors which cause internal vulnerability include low-income, insufficient education or lack of an 
informal network for support. The external side on the other hand concerns the covariate risks, stress and shocks present in the surrounding environment which threaten the livelihood security of all members of a community or whole society. Examples of possible events which cause external vulnerability include a conflict, natural disaster or macro-economic crisis. While the external side is the underlying cause of uncertainty over time, and the internal side reinforces poverty once a shock hits, it is the combination of the two which constitutes vulnerability (Ahmed \& Gassmann, 2009).

This breakdown into separate internal and external components, while conceptually helpful, is also practical when attempting to operationalize vulnerability as it distinguishes it from the more common poverty measurement (Ahmed \& Gassmann, 2010). Given the internal component gauges low coping ability, it can be measured by the individual's or household's lack of entitlements. The external component on the other hand gauges uncertainty in the environment, and may be measured by the individual's or household's exposure to risk. Therefore in sum, it is both the lack of entitlements (internal) and the exposure to risk (external) which creates vulnerability and ultimately influences well-being.

Beyond simply separating into two components, in order to more comprehensively measure vulnerability it is ideal to take a multidimensional approach in line with recent efforts of poverty measurement. ${ }^{8}$ Here, it proves useful to think of functioning losses individuals and households face categorized by entitlements and capabilities. In a fragile environment like Afghanistan, functioning losses may be put into four broad dimensions: (1) loss in human security; (2) loss in exchange freedom; (3) loss in social capital and (4) loss in access. The first, loss in human security, relates to individual security and well-being over time and incorporates deprivation in income, health, shelter and the like. The second, loss in exchange freedom, includes a shortage in resources able to be consumed or traded as well as the inability to gain additional resources through the labor market. The third, loss in social capital, describes a reduction in the sense of belonging of individuals within a particular network, resulting in less informal sources of support. And the

\footnotetext{
${ }^{8}$ See for example Bourguignon and Chakravarty (2003); Roelen et al. (2009); Alkire and Santos (2010); Alkire and Foster (2011); Gassmann et al. (2012).
} 
fourth, loss in access, consists of the absence of infrastructure or under-utilization of fundamental social services necessary for a healthy socio-economic environment (Ahmed \& Gassmann, 2009, p. 25-26).

Following the classification of these four dimensions of losses within the two separate components of vulnerability, the next step is to identify specific indicators for measurement. As in any exercise of this nature, the choice of indicators is routinely considered discretionary and dependent on the objectives of the study. Nevertheless, our decision to include certain indicators is determined by a review of similar studies in the literature and normative reasoning based on how well they capture the idiosyncrasies of the particular context in question, all while taking into account the more practical consideration of data availability.

We then follow the 'dual cutoff' method developed by Alkire and Foster (2011) which first assigns individual thresholds in order to classify a household as deprived or not for a particular indicator, before applying an overall cutoff for both dimensional and multidimensional vulnerability. Regarding thresholds, our choices are again largely driven by the literature and in line with Ahmed and Gassmann (2010, p. 11-12), or by the data itself where no clear threshold exists. For example, the threshold for 'average income per capita' follows the $\$ 1.25 /$ day poverty line developed by Ravallion et al. (2009) and subsequently adopted by the World Bank, while the threshold for 'number of able-bodied household members employed' is relative to the particular context and derived by taking the mean estimate of the sample. The final list of all indicators broken down by dimension and component, along with their corresponding thresholds used to gauge deprivation and subsequently profile household vulnerability is listed in Table 1.

As for both the dimensional and multidimensional cutoff which allows us to categorize a household as vulnerable or not, consideration of past exercises of a similar nature but also of the number of indicators within each dimension leads us to ultimately set it at 33 percent. Hence, a household is considered vulnerable if deprived in over a third of the individual indicators, weighted equally, within that dimension. The formal expression of the dimensional vulnerability index $(D V I)$ for dimension $d$ is: 


$$
\begin{gathered}
D V I_{d}=\frac{1}{n} \sum_{i=1}^{n} D V_{i d}, \text { where } \\
D V_{i d}=1 \text { if } \sum_{x=1}^{d} w_{x} i_{i x}>k .
\end{gathered}
$$

Here $n$ represents the number of households; and $D V_{i d}$ is the binary variable for dimensional vulnerability for household $i$, taking a value of one if the aggregated and weighted indicators in that dimension, $w_{x} i_{i x}$, is greater than the cutoff, $k$, which equals 33 percent. As noted, each indicator within a dimension is weighted equally and sums up to one.

When scaling up to the multidimensional level by aggregating all indicators across dimensions, the procedure is by and large identical. The only essential difference is that dimensions are now weighted equally causing individual indicators to be given a relative weight depending on the absolute number of indicators making up each particular dimension. ${ }^{9}$ A household deprived in more than a third of individual indicators with varying relative weights across dimensions is characterized as multidimensionally vulnerable. Formally the multidimensional vulnerability index $(M V I)$ can be expressed as:

$$
\begin{gathered}
M V I=\frac{1}{n} \sum_{i=1}^{n} O V_{i}, \text { where } \\
O V_{i}=1 \text { if } \sum_{x=1}^{d} w_{x} i_{i x}>k .
\end{gathered}
$$

\footnotetext{
9 Relatively weighting indicators across dimensions in effect gives more importance to those indicators located within dimensions with a less absolute number of indicators. While equally weighting individual indicators across dimensions does lead to a slightly higher overall MVI score, it does not change in any significant way the later presented findings of the regression analysis indicating the robustness of results.
} 
Here $O V_{i}$ is a binary variable for overall vulnerability for household $i$ taking a value of one if the aggregated and weighted indicators across all dimensions, $w_{x} i_{i x}$, is greater than the cutoff, $k$, which again equals 33 percent. As stated, each dimension is weighted equally and sums up to one while each indicator is given a relative weight dependent on the absolute number of indicators within that dimension.

Lastly, after identifying which households are considered multidimensional vulnerable, we go one step further by indicating the degree of vulnerability. Here, we simply categorize a multidimensionally vulnerable household as either 'less vulnerable' if deprived between our original cutoff of 33 percent and a newly applied 50 percent cutoff, or 'very vulnerable' if surpassing the 50 percent cutoff. In other words, a multidimensionally vulnerable household deprived in up to a half of all indicators, relatively weighted, across dimensions is understood to be less severely vulnerable than those households which are deprived in more than a half of all indicators, relatively weighted, across dimensions.

\section{Empirical Approach}

Following measurement of household vulnerability within each dimension and across dimensions, we then introduce a regression analysis using a probit model to estimate the predicted probability that a household contains an individual with the intention to migrate. The formal expression of the model is:

$$
P\left(M_{i}=1 \mid X_{i}\right)=\phi \beta_{i} X_{i}
$$

where $M_{i}$ indicates the binary dependent variable of household $i$ taking the value of one if it contains an individual with concrete plans to migrate abroad, and zero otherwise; $X_{i}$ is the binary independent variable indicating treatment based on whether the household is characterized as deprived on an individual indicator, $I_{x}$, or vulnerable on a particular dimension, $D V I_{d}$, or across all dimensions, $M V I ; \beta_{i}$ represents the regression parameter to be estimated; and $\phi$ indicates the cumulative normal distribution function. The models are estimated using robust standard errors and controlled for by whether the household has a member who is a current migrant, whether there is a return migrant in the household, household size, ethnicity, district type and province. 


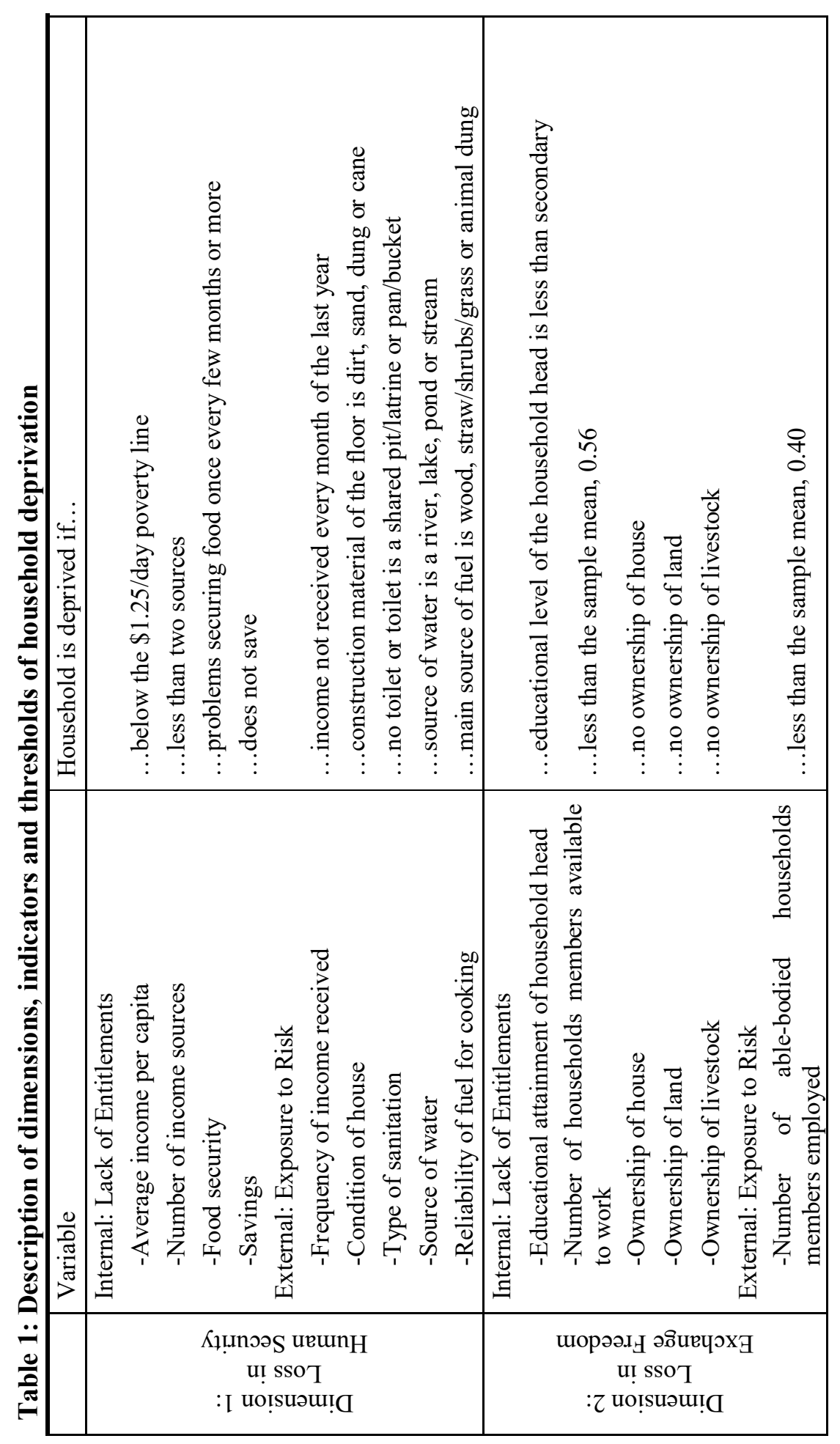









\section{Sample}

This study takes advantage of data originating from the household survey collected for the IS Academy 'Migration \& Development: a World in Motion' project. The overall sample is comprised of 2,005 households, with one main respondent answering for all household members. Table 2 illustrates the total number of households with at least one member having concrete plans to migrate abroad, disaggregated by where they are located in terms of district type. Of all households in our sample 349 , or 17 percent, have a member with intentions to migrate. Noticeably, urban households are twice as likely as having a member with migration intentions compared to rural households, with semi-rural households falling in between.

Table 2: Migration intentions

\begin{tabular}{lcccc}
\hline \hline & \multicolumn{3}{c}{ District Type } & \multirow{2}{*}{ Total } \\
\cline { 2 - 4 } & Urban & Semi-Rural & Rural & 1,656 \\
No & 785 & 424 & 447 & $82.59 \%$ \\
Yes & $78.27 \%$ & $84.80 \%$ & $89.04 \%$ & 349 \\
& 218 & 76 & 55 & $17.41 \%$ \\
\hline
\end{tabular}

Table 3 presents the summary statistics for households in our sample, disaggregated by migration intentions to provide a simple mean difference based on the t-test in the final column. First, we see around 10 percent of the total sample has a current migrant in the household while 55 percent report a return migrant, neither of which show a statistically significant mean difference regarding migration intentions. The average household size is seven members, also not significantly different across intentions. The majority of the sample, nearly 90 percent, is either Pashtun or Tajik corresponding to the two largest ethnic groups in the country, with all having a statistically significant mean difference. By design the sample is around two-to-one urban relative to semi-rural and rural, with both urban and rural having a statistically significant mean difference between intentions. And finally respondents are spread nearly evenly across all five provinces again per design, with a statistically significant mean difference between migration intentions in Herat, Balkh and Kandahar. 
Table 3: Summary statistics (\%)

\begin{tabular}{|c|c|c|c|c|}
\hline & \multirow[b]{2}{*}{ Full Sample } & \multicolumn{2}{|c|}{ Migration Intentions } & \multirow[b]{2}{*}{ t-test } \\
\hline & & No & Yes & \\
\hline Migrant $\mathrm{HH}$ & 10.27 & 9.96 & 11.75 & \\
\hline Return Migrant HH & 54.81 & 53.99 & 58.74 & \\
\hline HH Size & 7.38 & 7.41 & 7.21 & \\
\hline \multicolumn{5}{|l|}{ Ethnicity: } \\
\hline Pashtun & 43.94 & 46.98 & 29.51 & $* * *$ \\
\hline Tajik & 43.64 & 42.15 & 50.72 & $* * *$ \\
\hline Other & 12.42 & 10.87 & 19.77 & $* * *$ \\
\hline \multicolumn{5}{|l|}{ District Type: } \\
\hline Urban & 50.02 & 47.40 & 62.46 & $* * *$ \\
\hline Semi-Rural & 24.94 & 24.60 & 21.78 & \\
\hline Rural & 25.04 & 26.99 & 15.76 & $* * *$ \\
\hline \multicolumn{5}{|l|}{ Province: } \\
\hline Kabul & 20.05 & 20.29 & 18.91 & \\
\hline Herat & 20.00 & 21.20 & 14.33 & $* * *$ \\
\hline Balkh & 19.95 & 14.98 & 43.55 & $* * *$ \\
\hline Nangarhar & 20.05 & 19.99 & 20.34 & \\
\hline Kandahar & 19.95 & 23.55 & 2.87 & $* * *$ \\
\hline
\end{tabular}

Significance Levels: ${ }^{* * *} \mathrm{p}<0.01,{ }^{*} \mathrm{p}<0.05,{ }^{*} \mathrm{p}<0.10$.

\section{$2.4 \quad$ Results}

This section first illustrates the descriptive results for our measurement of household deprivation along each individual indicator, as well as both dimensional and multidimensional vulnerability. Finally, the empirical results of the regression analysis are presented.

\section{Descriptive Results}

Table 4 exhibits the percentage of household deprivation for each indicator, again disaggregated by migration intentions to illustrate the mean difference. Moreover, the results are broken down by dimension and component allowing us to better identify where overall vulnerability originates from within our sample. 
Table 4: Household deprivation on each indicator by dimension (\%)

\begin{tabular}{llccc}
\hline \hline & & \multicolumn{2}{c}{ Migration Intentions } & \\
& Full Sample & No & Yes & t-test \\
\hline Dimension 1: Loss in Human Security & & & & \\
Internal: Lack of Entitlements & & & & \\
$\quad$ Average income per capita less than & 20.15 & 20.29 & 19.48 & \\
$\quad \begin{array}{l}\text { \$1.25/day } \\
\text { Less than two income sources }\end{array}$ & 60.85 & 59.42 & 67.62 & $* * *$ \\
$\quad$ Problems satisfying food needs once & 55.56 & 56.70 & 50.14 & $* *$ \\
$\quad$ every few months & 86.53 & 87.08 & 83.95 & \\
$\quad$ No savings & & & & \\
External: Exposure to Risk & 4.60 & 4.61 & 4.58 & \\
$\quad$ Income received less than 12 months/yr. & 4.60 & 4.36 & 5.76 & \\
$\quad$ Poor condition of house & 7.48 & 8.64 & 2.01 & $* * *$ \\
$\quad$ Poor sanitation & 13.19 & 13.13 & 13.47 & \\
$\quad$ Unhealthy source of water & 54.29 & 57.89 & 37.25 & $* * *$ \\
$\quad$ Unreliable source of fuel & & & & \\
\hline
\end{tabular}

\section{Dimension 2: Loss in Exchange Freedom}

Internal: Lack of Entitlements

Educational attainment of household

head below secondary level

$63.89 \quad 67.57 \quad 46.42 \quad * * *$

Number of households members

available to work below the sample mean

$54.42 \quad 53.50 \quad 47.28 \quad * *$

No ownership of house

27.33

$26.75 \quad 30.09$

No ownership of land

79.30

$78.20 \quad 84.53$

No ownership of livestock

52.05

59.03

External: Exposure to Risk

Number of able-bodied households

members employed below than sample

36.16

35.51

39.26

mean

\section{Dimension 3: Loss in Social Capital}

Internal: Lack of Entitlements

No membership in community

organizations

32.52

36.11

15.47

$* * *$

No informal help from social networks

30.00

30.17

29.23

External: Exposure to Risk

Quality of social networks is low

5.49

5.26

6.61 


\begin{tabular}{lcccc}
\hline Dimension 4: Loss in Access & & & & \\
Internal: Lack of Entitlements & 31.09 & 33.81 & 17.83 & $* * *$ \\
$\quad$ No use of school & 9.83 & 10.02 & 8.88 & \\
No use of health services & 91.32 & 92.57 & 85.39 & $* * *$ \\
No use of financial services & & &
\end{tabular}

Significance Levels: ${ }^{* * *} \mathrm{p}<0.01,{ }^{* *} \mathrm{p}<0.05,{ }^{*} \mathrm{p}<0.10$.

By first focusing on the totals column, one of the initial observations is the diversity in deprivation across each dimension. Taking into consideration the prolonged exposure to conflict Afghan households have faced over the years, it is no surprise many are deprived along a broad range of measures gauging an overall standard of living. Deprivation within Dimension 1: Loss in Human Security, for example, illustrates the impoverished state of households in terms of economic well-being, health and condition of housing. We find that even though only 20 percent of our sample lives below the internationally recognized poverty line of $\$ 1.25 /$ day and five percent receive income less than 12 months over the year, some 61 percent cannot count on more than two sources of income while 87 percent do not save. This shows that while absolute poverty is not as pervasive or unstable in comparison to original expectations, the majority of households have little protection in the case of loss of employment. In terms of health, some 56 percent have trouble satisfying food needs at least every few months, even though only 13 percent have an unhealthy source of water and seven percent poor sanitation based on the type of toilet. Again, even though a relatively low number of households do not have access to safe drinking water or sanitation, more than half are prone to high food insecurity reflecting their exposure to malnutrition. As for the condition of the household, 54 percent of the sample does not have a reliable source of fuel, despite only five percent having a poor living condition indicated by flooring. An unreliable source of fuel is particularly detrimental in the winter months, putting those households at risk of extreme weather conditions common to the setting.

Deprivation within Dimension 2: Loss in Exchange Freedom depicts the household's low level of endowment, as well as its inability to build upon that endowment through the labor market in order to strengthen resilience. In terms of assets, 79 percent of households do not own any land, while 53 percent have no livestock and 27 percent do not own a house. In an agricultural-based economy, this high deficiency in land and livestock ownership puts a serious restriction on 
any agricultural-based production, either for subsistence or trade purposes. As for human capital and labor, a notable 64 percent of household heads have below secondary level education, while 54 percent of the sample falls below the sample mean regarding the number of household members available to work and 36 percent below the sample mean concerning the number of able-bodied members that are actually employed. This illustrates how a disproportionately high number of households, nearly two-thirds, are confined to low-skill labor activities, while more than half have a comparatively low availability of labor to support household earnings and more than a third under-utilize that available labor relative to the rest of the sample.

Deprivation within Dimension 3: Loss in Social Capital describes the low level of belonging and thus opportunity for informal support households have due to social exclusion. Indeed, 33 percent of households are not associated with any community organization, while similarly 30 percent state they cannot count on informal help from their social network. Still, only five percent have a low quality social network based on trust of community members. This shows that while trust appears particularly high at the local level, a fair amount of households have limited contact to others outside their immediate family making them less aware of their surroundings and giving them less sources of informal support to lean on when times are bad.

Finally, deprivation along Dimension 4: Loss in Access outlines the underutilization of fundamental social services necessary for a healthy socio-economic environment. Within our sample, 91 percent of households do not use any formal financial service including a bank, money transfer operator or microfinance institution, while 31 percent have at least one child aged 6-14 not attending school. On the other hand, only 10 percent of households do not utilize any health services including a health clinic or hospital. While unsurprising given the context, these figures indicate many households in Afghanistan still overwhelmingly rely on informal sources of finance including the hawala system, limiting their opportunities to take advantage of certain beneficial financial services like savings accounts or micro-credit which may help hedge against future income shocks. Moreover, the nearly one-third of households failing to send all children to school despite their being located in the community limits future labor to low-skill activities. 
Beyond simply looking at the total deprivation along individual indicators, we also notice key differences when cross-tabulating with migration intentions of at least one household member. Table 5 summarizes those variables which have a statistically significant p-value at least at the five percent confidence level. Tellingly, most variables show deprivation being associated with a lower probability of concrete plans to move abroad, while only a few are positively related. Even though these are only crude associations, it gives a general idea of how individual indicators of deprivation relate to whether a household has a member with intentions to migrate, and will be dealt with in more detail with the regression analysis.

Table 5: Statistically significant mean difference across migration intentions

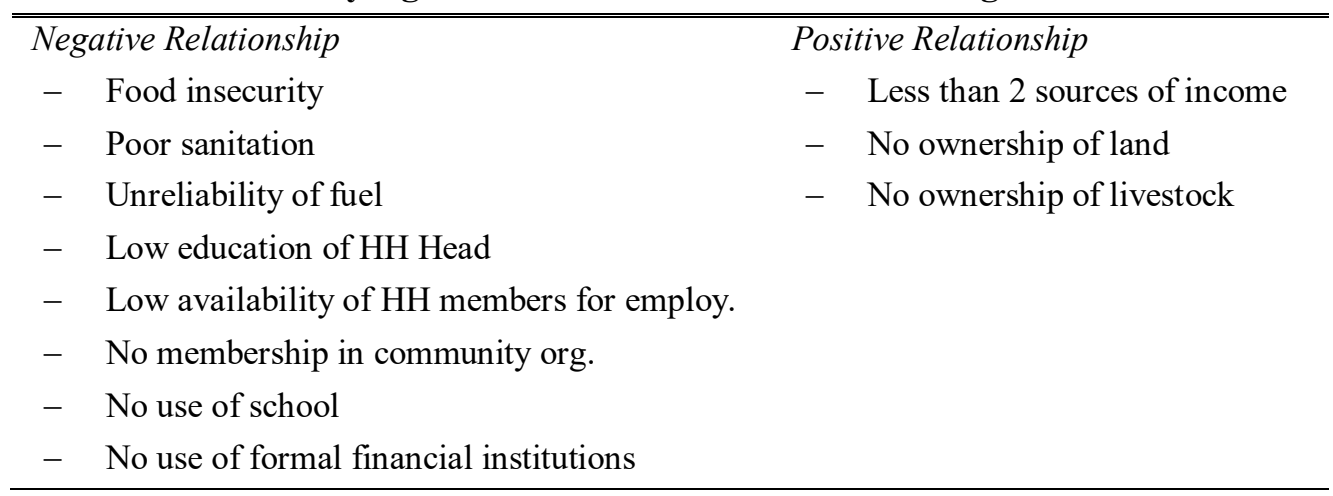

Further along, Table 6 presents household vulnerability for each dimension using the earlier explained 33 percent cutoff, meaning a household is classified as dimensionally vulnerable if deprived in more than a third of all equally weighted indicators within that particular dimension. Focusing on the totals column, we notice household vulnerability is most extreme for Dimension 2: Loss in Exchange Freedom, as 70 percent of our sample is categorized as such. Moreover, vulnerability along Dimension 1: Loss in Human Security and Dimension 4: Loss in Access is similar at 36 percent and 35 percent respectively, while only 13 percent of households are categorized as vulnerable within Dimension 3: Loss in Social Capital. Looking at the mean difference across migration intentions, we find the relationship is negative and statistically significant, at least at the 10 percent level, for all dimensions apart from the second. 
Table 6: Dimensional household vulnerability (\%)

\begin{tabular}{lcccc}
\hline \hline & & \multicolumn{3}{c}{ Migration Intentions } \\
\cline { 3 - 4 } & Full Sample & No & Yes & t-test \\
\hline Dimension 1: Loss in Human Security & 36.42 & 37.23 & 32.56 & $*$ \\
Dimension 2: Loss in Exchange Freedom & 70.42 & 70.29 & 71.06 & \\
Dimension 3: Loss in Social Capital & 12.70 & 13.98 & 6.61 & $* * *$ \\
Dimension 4: Loss in Access & 35.00 & 37.67 & 21.97 & $* * *$ \\
\hline
\end{tabular}

Significance Levels: $* * * \mathrm{p}<0.01, * * \mathrm{p}<0.05,{ }^{*} \mathrm{p}<0.10$.

Lastly, Table 7 presents the multidimensional vulnerability index along with a measure of degree. Here we find that 71 percent of our sample is categorized as multidimensionally vulnerable, meaning they are deprived in over a third of all indicators, relatively weighted, across dimensions. Of that amount, 16 percent are considered 'very vulnerable' meaning they are deprived in over half of all indicators. Moreover, the mean difference across migration intentions is negative and statistically significant for all measures.

Table 7: Multidimensional household vulnerability (\%)

\begin{tabular}{ccccc}
\hline \hline & & \multicolumn{2}{c}{ Migration Intentions } & \\
\cline { 3 - 4 } & Full Sample & No & Yes & t-test \\
\hline Multidimensional Vulnerability Index & 70.64 & 73.40 & 57.23 & $* * *$ \\
Less Vulnerable & 54.99 & 56.25 & 48.87 & $* *$ \\
Very Vulnerable & 15.64 & 17.14 & 8.36 & $* * *$ \\
\hline
\end{tabular}

Significance Levels: $* * * p<0.01,{ }^{* *} \mathrm{p}<0.05,{ }^{*} \mathrm{p}<0.10$.

\section{Empirical Results}

In light of the household profile, we here provide estimates of the probit model to empirically measure the influence of individual indicators of deprivation as well as both dimensional and multidimensional vulnerability on migration intentions. Because coefficients of the probit model are inherently problematic to interpret, we report the marginal effect along with the t-statistic. Moreover as stated prior, all regressions are estimated using robust standard errors and controlled for by whether the household has a current migrant abroad, whether the household reports a return migrant, household size, ethnicity, district type and province. 
Table 8 presents our results regarding the influence of individual indicators of deprivation on migration intentions, initially grouped by each dimension separately before a full model. Supporting the earlier mean difference test, we find little evidence of deprivation leading to a higher probability of intentions to migrate. Of the few coefficients with a positive sign, only 'Quality of Networks' is statistically significant. Intuitively, this gives slight suggestion that the lower level of trust one has for members of the community, the more likely a household member intends to migrate. On the contrary, a number of coefficients have a negative sign indicating again that deprivation leads to a lower likelihood of having a household member with concrete plans to migrate abroad. Of those which are statistically significant across both the dimensional and full models, 'Education of Household Head' and 'Membership in Community Organization' explicitly relate to human and social capital, suggesting that the less educated with a smaller social network are less aware of the potential opportunities outside their current location or less capable to make the costly journey, leading to lower aspirations. This finding is supported by the fact that 'Help from Social Networks', also relating to social capital, is negative and statistically significant within the full model, despite it losing significance in the dimensional model. Furthermore, household deprivation in terms of 'Food Security', 'Household Savings', 'Sanitation' and 'Reliability of Fuel' are likewise statistically significant across both the dimensional and full models, as is deprivation regarding 'Use of School' and 'Use of Financial Services'. This suggests a disadvantaged household with a worse general state of affairs and without use of basic services is less likely to have a member planning to move.

Table 9 provides the results regarding the influence of dimensional vulnerability on migration intentions for each of the four dimensions, again initially reported separately before a full model. Consistent with our previous finding, we see that dimensional vulnerability has a negative marginal effect across all models with each statistically significant apart from Dimension 2. The negative effect for Dimension 3 is most pronounced at nine percent, providing further evidence that social capital is essential for aspirations to migrate. Likewise a household vulnerable within Dimensions 1 and 4 is on the margin four percent less likely to have concrete plans to move abroad. 


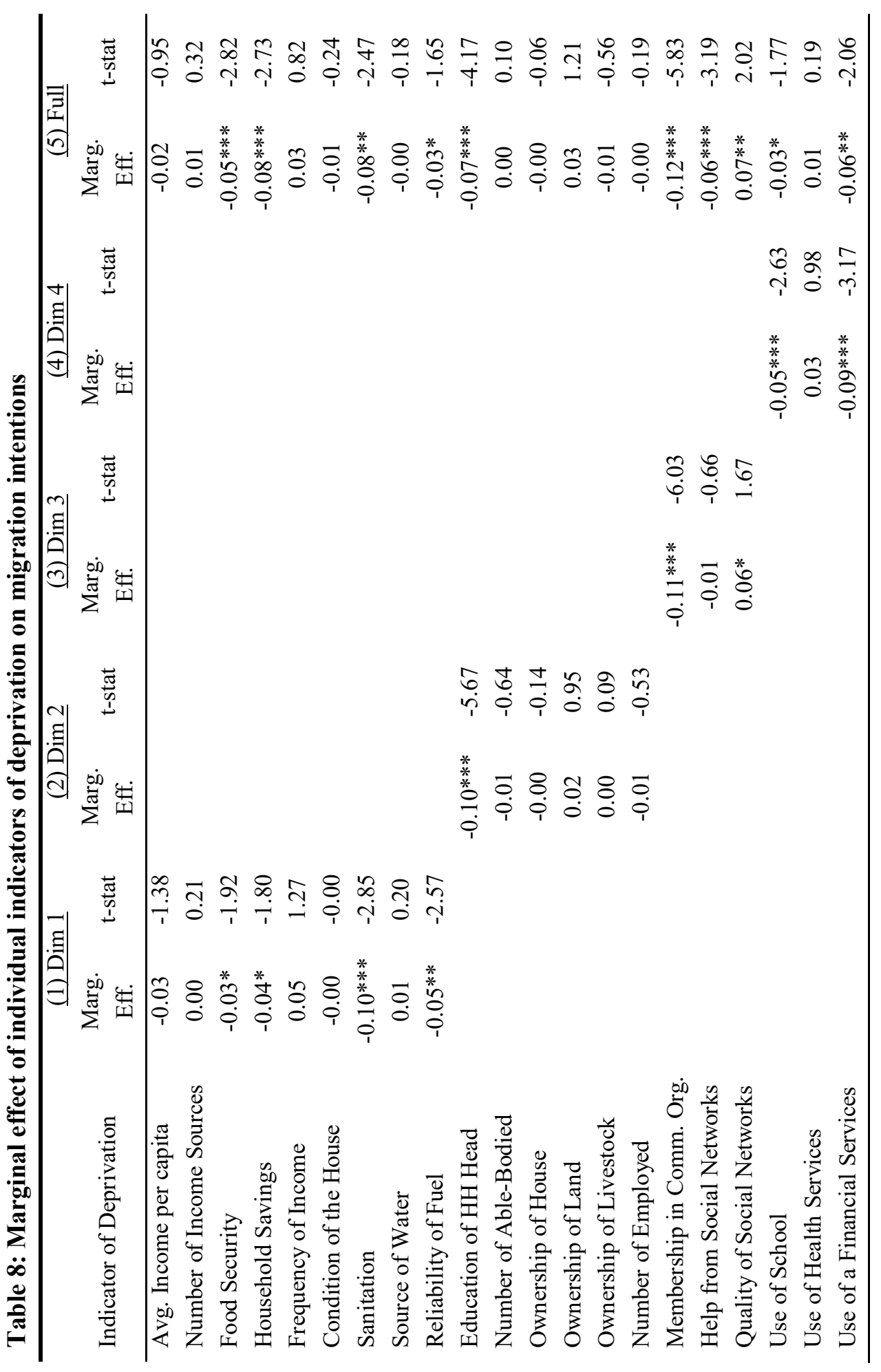




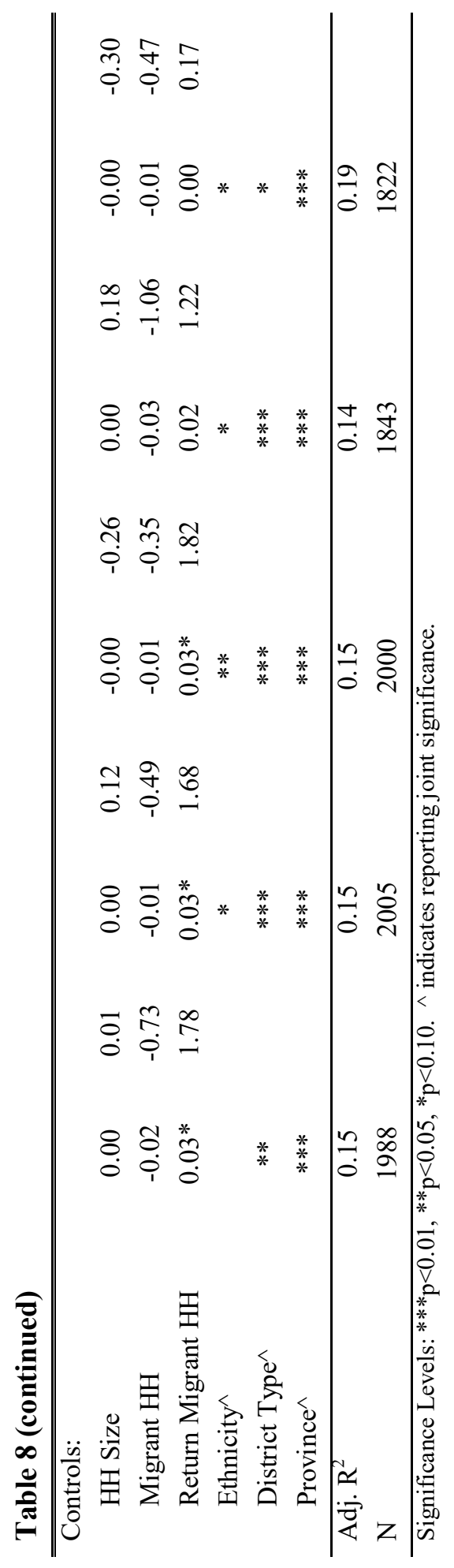




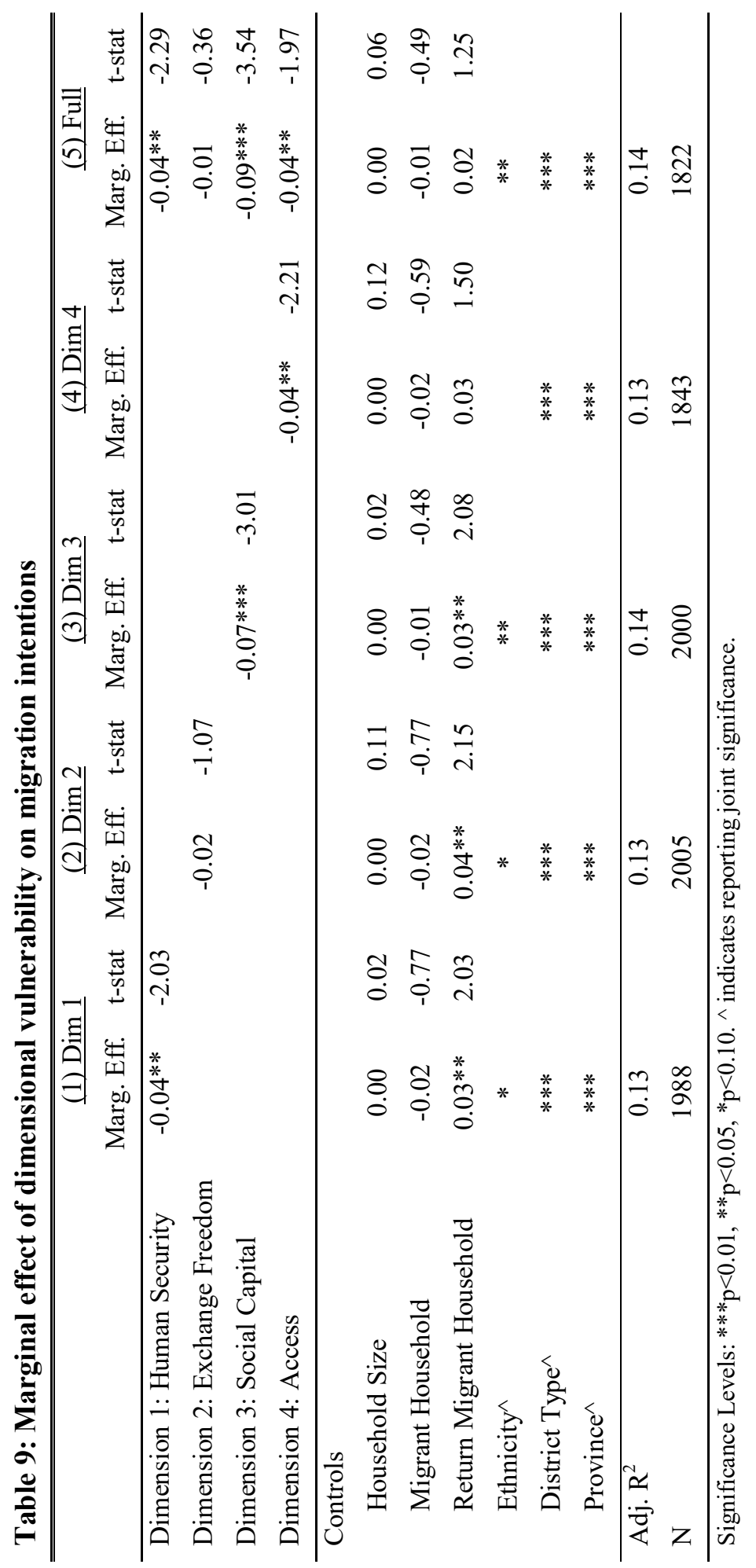


Finally, Table 10 presents the results regarding the influence of multidimensional vulnerability and its degree on migration intentions. In line with the prior findings, a household categorized as multidimensionally vulnerable is on the margin 10 percent less likely to have a member with concrete plans to migrate, statistically significant at the one percent level. What is more, the effect is slightly more pronounced for those household deemed 'very vulnerable' in comparison to those households considered 'less vulnerable', both statistically significant again at the one percent level.

Table 10: Marginal effect of multidimensional vulnerability on mig. intentions

\begin{tabular}{|c|c|c|c|c|}
\hline & \multicolumn{2}{|c|}{ (1) MVI } & \multicolumn{2}{|c|}{ (2) Degrees of MVI } \\
\hline & Marg. Eff. & t-stat & Marg. Eff. & t-stat \\
\hline Multidimensional Vulnerability Index & $-0.10 * * *$ & -5.26 & & \\
\hline Less Vulnerable & & & $-0.09 * * *$ & -4.71 \\
\hline Very Vulnerable & & & $-0.10 * * *$ & -4.31 \\
\hline \multicolumn{5}{|l|}{ Controls } \\
\hline Household Size & 0.00 & 0.16 & 0.00 & 0.21 \\
\hline Migrant Household & -0.03 & -0.97 & -0.03 & -0.99 \\
\hline Return Migrant Household & 0.02 & 1.16 & 0.02 & 1.05 \\
\hline Ethnicity^ & $*$ & & $*$ & \\
\hline District Type $^{\wedge}$ & $* * *$ & & $* * *$ & \\
\hline Province $^{\wedge}$ & $* * *$ & & $* * *$ & \\
\hline Adj. $\mathrm{R}^{2}$ & 0.14 & & 0.14 & \\
\hline $\mathrm{N}$ & 1822 & & 1822 & \\
\hline
\end{tabular}

Significance Levels: $* * * \mathrm{p}<0.01,{ }^{* *} \mathrm{p}<0.05,{ }^{*} \mathrm{p}<0.10 .{ }^{\wedge}$ indicates reporting joint significance.

\subsection{Conclusion}

This analysis investigates whether household vulnerability influences the intentions to migrate within a particular context characterized by a high degree of instability. While it is commonplace to conceptualize migration as being driven by certain economic-related factors, it is reasonable to assume that in an insecure setting like Afghanistan the difference between voluntary and involuntary movement is not easily distinguishable, making it necessary to approach the subject through a 
broader spectrum. The use of household vulnerability as a measure which incorporates a range of socio-economic factors allows for a more comprehensive analysis which does not presuppose movement is economic in nature.

The empirical results of our analysis are in line with those hypotheses put forth by the New Economics of Labor Migration. In particular it is not the "poorest of the poor', or more appropriately for our purposes the 'most vulnerable of the vulnerable', that have concrete plans to migrate abroad. Indeed, a household categorized as multidimensionally vulnerable is on the margin 10 percent less likely to have a member with intentions to move compared to non-vulnerable households, with the negative marginal effect slightly larger for those households deemed 'very vulnerable' in comparison to those deemed 'less vulnerable'. Given the inherent costs and risks in leaving ones' home, it appears Afghan households have a realistic understanding about their capabilities to actually migrate, ultimately shaping their expectations and aspirations. At the macro-level, this result likewise offers support to the 'migration hump' theory in which socio-economic development leads to increased movement, at least in the medium-term.

Concerning those specific vulnerability-related factors associated with intentions to migrate, our results shows that a household suffering from deprivation along a variety of individual indicators related in particular to human and social capital, but also to a more general state of affairs and access to basic services is less likely to have a member with concrete plans to move. Those households for example with low education of the household head as well as no membership in a community organization are noticeably less likely in having a member intend to migrate. Likewise, households suffering from food insecurity, low savings, poor sanitation and an unreliable source of fuel as well as no use of schools and formal financial services are also associated with a lower probability that a member has intentions to migrate abroad.

While our results are revealing, it is important to note that this analysis is not without its limitations. Most evident, the use of intentions is a less-than-perfect proxy for actual behavior. Even though a number of studies on the topic have suggested migration intentions are to a certain extent a good predictor of future migration behavior, the use of actual migration behavior is preferred. Still, even though the lack of robust data on actual migration behavior in our own sample 
makes any such analysis problematic, the use of intentions has the benefit of circumventing the issue of endogeneity between vulnerability and migration, something which must be faced head-on when using data for actual behavior. Secondly, the construction of dimensional and multidimensional indices includes with it many discretionary choices regarding indicators, thresholds and cutoffs. In this regard, our decisions were foremost driven by the literature as well as by the particular context in question and data availability. In this way, we hope to have minimized any biases which are bound to arise when constructing an index of this sort. 


\section{Works Cited}

Ahmed, M., \& Gassmann, F. (2009). Defining Vulnerability in Post Conflict Environments. (Working Paper 022). Maastricht Graduate School of Governance.

Ahmed, M., \& Gassmann, F. (2010). Measuring Multidimensional Vulnerability in Afghanistan. (MGSoG Working Paper 004). Maastricht Graduate School of Governance.

Alkire, S., \& Foster, J. (2011). Counting and multidimensional poverty measurement. Journal of Public Economics, 95, 476 - 487.

Alkire, S., \& Santos, M. E. (2010). Acute Multidimensional Poverty: A New Index for Developing Countries. (OHPI Working Paper 38). Oxford Department of International Development, University of Oxford.

Bourguignon, F., \& Chakravarty, S. (2003). The measurment of multidimensional poverty. Journal of Economic Policy, 1, 25 - 49.

Central Statistics Office (CSO). (2014). National Risk and Vulnerability Assessment 2011/2012. Afghanistan Living Conditions Survey. Kabul: Central Statistics Office.

Chambers, R. (1989). Vulnerability, Coping and Policy. IDS Bulletin, 20(2), 1 - 7.

Creighton, M. (2013). The role of aspirations in domestic and international migration. The Social Science Journal, 50(1), 79 - 88.

de Haas, H. (2009). Mobility and Human Development. (Human Development Research Paper 2009/01). UNDP.

de Haas, H. (2010a). Migration and Development: A Theoretical Perspective. International Migration Review, 44(1), 227 - 264.

de Haas, H. (2010b). Migration transitions - a theoretical and empirical inquiry into the deelopmental drivers of international migration. (IMI Working Paper 24). International Migration Institute, University of Oxford.

de Jong, G. F. (2000). Expectations, Gender, and Norms in Migration DecisionMaking. Population Studies, 54(3), 307 - 319.

Gardner, R. W., de Jong, G. F., Arnold, F., \& Carino, B. V. (1985). The Best-Laid Schemes: An Analysis of Discrepencies between Migration Intentions and Behavior. Population and Environment, 8(1/2), 63 - 77.

Gassmann, F., Siegel, M., Vanore, M., \& Waidler, J. (2012). The impact of migration on elderly left behind in Moldova. (UNU-MERIT Working Paper 082). Maastricht Graduate School of Governance. 
Jodha, N. S. (1988). Poverty Debate in India: A Minority View. Economic and Political Weekly, 23(45/47), 2421 - 2427.

Kothari, U. (2002). Migration and Chronic Poverty. (IDPM Working Paper 16). Institute for Development Policy and Management, University of Manchester.

Moser, C. (1998). The Asset Vulnerability Framework: Reassessing Urban Poverty Reduction Strategies. World Development, 26(1), 1 - 19.

Prowse, M. (2003). Towards a clearer understanding of 'vulnerability' in relation to chronic poverty. (CPRC Working Paper 24). Chronic Poverty Research Centre.

Ravallion, M., Chen, S., \& Sanraula, P. (2009). A Dollar A Day Revisited. World Bank Economic Review, 23(2), 163 - 184.

Roelen, K., Gassmann, F., \& de Neubourg, C. (2009). Child Poverty in Vietnam Providing insights using a country-specific and multidimensional model. (MGSoG Working Paper 2009/01). Maastricht Graduate School of Governance.

Sen, A. (1981). Poverty and Famines: An Essay on Entitlement and Deprivation. Oxford: Oxford University Press.

Sen, A. (1999). Development as Freedom. Oxford: Oxford University Press.

Stark, O., \& Bloom, D. E. (1985). The New Economics of Labor Migration. American Economic Review, 75(2), 173 - 178.

Taylor, J. E., \& Dyer, G. A. (2009). Migration and the Sending Economy: A Disaggregated Rural Economy-Wide Analysis. Journal of Development Studies, 45(6), 966 - 989.

United Nations High Commissioner for Refugees (UNHCR). (2015). UNHCR Statistical Online Population Database. Retrieved September 1, 2015, from $<$ www.unhcr.org/statistics/populationdatabase $>$.

Van Dalen, H. P., \& Henkens, K. (2008). Emigration Intentions: Mere Words or True Plans? Explaining International Migration Intentions and Behavior. Discussion Paper 60). Center for Economic Research, Tilburg University. 



\section{Chapter 3}

\section{Revisiting the Motivations behind Remittance Behavior $^{10}$}

\subsection{Introduction}

Within the overall discussion concerning migration and development, the issue of remittance sending is of great interest for both academics and policymakers alike. Cross-border transfers to low-income countries of origin have shown resilient growth in the face of the recent economic downturn, providing further proof of its significance for many households throughout the developing world (Aga et al., 2013). Still, any potential positive impact on household welfare is not automatic and likely very much related to what motivates money to be sent in the first place. A migrant remitting under the pretense of paying for a family member's education, for example, has different implications than if it were for building a house in preparation for an eventual return. It is with this in mind that a plethora of empirical analysis has been carried out over the years looking to identify the determinants of remittance behavior. While these studies' findings have helped advance our understanding of the issue, there still remains a great deal of ambiguity especially when it comes to less scrutinized forms of migration flows. Remittance behavior due to conflict-related migration, for instance, may fundamentally differ in comparison to labor migration, necessitating further consideration of the dynamics associated with such cross-border financial flows in conflict and post-conflict settings (Lindley, 2008).

It is widely acknowledged that for many poor households, the act of migrating may be part of a household strategy in order to diversify income and therefore spread risk. As such, it may be the case that a family is only able to stay in their current

\footnotetext{
${ }^{10}$ This chapter is based on: Loschmann, C. \& Siegel, M. (2015). Revisiting the Motivations behind Remittance Behavior: Evidence of Debt-financed Migration from Afghanistan. Migration Letters, 12(1), 38 - 49.
} 
location because one individual member moved to another (Monsutti, 2006; 2008). Migration in this way can be thought of as a form of investment, with remittances as a form of return. Indeed, the expectation of remittances may be one of the most important motives for migrating (de Haas, 2010). However, changing locations today with an eye towards economic benefit tomorrow is not without costs. The entire household may bear the large up-front expenses of migration either through loans or gifts to the would-be migrant, with the understanding that money will be sent back at a future point in time (Clemens \& Ogden, 2013).

In this study we investigate the motivations behind remittance behavior of Afghan migrants, utilizing the way in which migration is financed as a discriminating factor. In line with the theoretical underpinnings of the New Economics of Labor Migration (NELM) where migration is understood as a household strategy, we look at whether the up-front costs of migration are covered by taking on an informal loan or gift and the influence this has on the remittance behavior of the migrant once abroad. In this way we are able to infer whether remittances are the product of debt-financed migration in light of an implicit contractual agreement between migrant and household of origin, suggesting a household risk-coping strategy. To the best of our knowledge, such an indicator used to distinguish remittance motivations has been employed only in a few other cases (Brown, 1997; Gubert, 2002), and never in a (post-) conflict environment similar to that of Afghanistan.

Exploring the underlying determinants of remittances is well-understood to be highly sensitive to the local contextual environment, with the Afghan setting being unique for a number of reasons. Most salient is the intermittent conflict that has plagued the country for nearly four decades, and the abject impoverishment many households face as a result. Even though the arrival of the international community following the Taliban's ouster in 2001 has led to marginal improvements, the present day situation is still characterized by high risks, a general lack of opportunity and widespread insecurity. In addition, there is a considerable amount of uncertainty that the situation will improve in the near future due to the recent political and security transitions (Koser, 2014). Many Afghan families, therefore, are left to contemplate their alternatives if their local situation happens to take a turn for the worse. In the face of such uncertainty, it is believed that a large share of households continue to rely on traditional migratory and economic networks based on the dispersion of members of households and kin groups across various 
locations including Pakistan and Iran (Monsutti, 2004; CSSR, 2006). Yet whether there is evidence of such a diversification strategy based on migration, or whether it rests on remittance transfers as an alternative source of income, is an empirical question and remains to be seen.

The remainder of the chapter is structured as follows. We first review the relevant theoretical and empirical literature regarding the motivations behind remittance behavior. This is followed by a presentation of our empirical strategy and a description of the sample. We then turn to our empirical results before concluding with a brief summary of our findings.

\subsection{Literature Review}

Prior to any discussion concerning the motivations to remit, it is helpful to first reflect on the determinants of migration given it is a prerequisite for remittances being sent. Traditionally migration theory originates from neoclassical economic thought focusing exclusively on the earnings gap between two locations. From this perspective, an individual moves to a destination if it maximizes expected utility based on a simple cost-benefit calculation (Harris \& Todaro, 1970). Therefore, the decision to migrate depends predominately on certain individual characteristics determining where $\mathrm{s} /$ he will be most productive and earn the highest income including age, experience, education, skills and the like (Massey et al., 1993).

Looking beyond merely the individual however, the NELM hypothesizes that the decision to migrate is not taken by just the potential migrant but within a larger social context typically incorporating the household or greater family. Migration therefore is driven by a collective effort to not merely maximize income, but also minimize risks to income generation (Stark \& Bloom, 1985; Taylor \& Dyer, 2009; de Haas, 2010). As such, migration is viewed as a means by which the household is able to increase capital assets, diversify sources of income and provide income insurance. Naturally then remittances enter the picture as one such channel through which the migrant is able to contribute to household well-being.

Stemming from the general premise of the NELM, the contemporary debate around the determinants of remittances began in earnest with the seminal paper by Lucas and Stark (1985), "Motivations to Remit: Evidence from Botswana". Here the 
authors go beyond the previously unqualified presumption that migrants send money merely because they care for those left behind, and provide a systematic theory of remittance behavior determined by one of three possibilities: 'pure altruism', 'pure self-interest' or 'tempered altruism/enlightened self-interest'. It is from this framework that the majority of contemporary empirical work on the subject builds.

Under the first motivation, 'pure altruism', migrants are understood to derive utility from their family's well-being. As such, remittance behavior ${ }^{11}$ is expected to be increasing with migrant income ${ }^{12}$ and decreasing with household income net of remittances, both of which are commonly found throughout the empirical literature (Hagen-Zanker \& Siegel, 2007). Beyond the influence of migrant and household income, however, which alone fails to exclusively identify altruism in comparison to others explanations, a common approach is to model the influence of other relevant factors including the presence of more than one migrant from the same household, household size and duration of time abroad. Regarding the former, Agarwal and Howoritz (2002) compare single migrant to multiple migrant households in Guyana, under the hypothesis that if altruism is the main driver of remittance behavior than it should be decreasing in the presence of other migrants given responsibility to care for those back home is spread evenly among all family members abroad. Ultimately, their finding of a negative relation between multiple migrant households and remittance behavior provides support for such a notion, and has been corroborated elsewhere (see, e.g., Naufal, 2008). As for household size, remittance behavior motivated by altruism is expected to be increasing with the greater number of family members there are to care for, and has been found in number of cases (Agarwal \& Howoritz, 2002; Gubert, 2002; Osili, 2007). For the duration of time abroad, the 'remittance decay' hypothesis expects remittance

\footnotetext{
${ }^{11}$ Remittance behavior here is used to indicate both the propensity to remit as well as the amount remitted. While some authors argue that both decisions may be made separately with possible different variables determining each, we follow Amuedo-Dorantes and Pozo (2006, p. 240) who contend, "it is difficult to conceive of factors that affect the decision to remit money home, but do not influence the amount remitted by the immigrant".

${ }^{12}$ Because of data limitations, migrant income is commonly proxied by other migrant characteristics which are likely to influence the migrant's income function including age, level of education, time abroad, etc.
} 
behavior under altruism to be decreasing over time due to an assumed weakening of social ties between migrant and household. Even though 'remittance decay' is found in certain cases (Holst \& Schrooten, 2006; Vargas-Silva, 2006), remittance behavior is also commonly seen to follow an inverted-U curve in that it initially is increasing as migrants become more established at destination and thus have greater capacity to earn and send, and only later declines as social contact wanes (Carling, 2008).

Under various forms of 'pure self-interest', migrants are understood to send money without the well-being of the family explicitly in mind, but rather as the name indicates considering only their own personal benefit. A migrant with aspirations to inherit may be one such case implying the opposite of the altruism hypothesis in that remittance behavior should be increasing with household wealth, something Lucas and Stark (1985) themselves found evidence of in the case of Botswana. Alternatively, remittance behavior driven by self-interest may be witnessed when money is sent in order to acquire physical assets like land, housing, livestock and the like in preparation for an ensuing return. Therefore, when possible it is convenient to include whether the migrant intends to return and the effect this has on remittance behavior, as shown in certain cases which support the self-interest explanation (Brown, 1997; de la Briere, 1997).

Lastly under 'tempered altruism/enlightened self-interest', remittances are seen as "part of an intertemporal, mutually beneficial contractual arrangement between migrant and home" (Lucas \& Stark, 1985, p. 904). This would be the case for instance if remittances were driven by a desire to repay the family for an initial investment in education or costs associated with migration. Remittance behavior, therefore, would be expected to be increasing in light of such formal or informal past economic exchanges including a loan to migrate, a finding which has been found in certain contexts (see, e.g., Brown, 1997; Gubert, 2002). Alternatively, if migration of a family member is a strategy to diversify sources of income and thus reduce risk, then money sent home can be understood as a form of co-insurance for both migrant and household. The family back home, for example, might help support the migrant during the initial stage abroad and possible periods of unemployment, while the migrant offers assistance to the household if they happen to endure a negative shock to their income-generating capabilities. The common approach to measure co-insurance includes focusing on the influence of the 
migrant's risk level or a fluctuation, or shock, to household income. For the former, Amuedo-Dorantes and Pozo (2006) use an indirect measure of migrant income risk and find robust evidence that remittance behavior is increasing with uncertainty in the host country pointing to both family and self-insurance. Batistas and Umblijs (2012) use a more direct measure of migrant income risk and similarly find remittance behavior increasing with migrant risk aversion which again points to self-insurance. For the latter, Lucas and Stark (1985) find evidence of remittance behavior increasing with a drought in the case of Botswana, while Pleitez-Chavez (2004) supports such a finding when exploiting data on negative household income shocks in El Salvador.

Table 11 sums ups the predicted relationship between remittance behavior and certain key characteristics of both the migrant and household at origin under all three motivation scenarios. While not exhaustive, each characteristic is commonly incorporated into the dozens of empirical analyses undertaken since Lucas and Stark (1985). The underlying objective has been to use these factors in order to identify one dominant motive from the others. Still, in reality it is very likely that a mixture of motives of varying degree exists within the same individual, not to mention heterogeneous individuals within a local context, or adjust over time (Rapaport \& Docquier, 2006). Indeed Lucas and Stark (1985) highlight the combination of altruistic and self-interested factors which allow for any arrangement between migrant and household as characterized by 'tempered altruism/enlightened self-interest' to be self-reinforcing. Therefore even though a single explanatory determinant is sought out, it is important to keep in mind the inherent interdependencies between motives.

In regards to context, even though the environments of the studies just cited vary migration in each is noticeably characterized by labor flows towards either the US or Western Europe with little consideration given to other forms of migration patterns or (post-) conflict settings. Certain studies, however, do provide insight into the remittance behavior of refugees which allow for a better understanding of migrant to household transfers when situated within a paradigm of insecurity. AlAli et al. (2001), for instance, analyze the transnational behavior of both Bosnian and Eritrean refugees in Western Europe and notice that while many do send money home, most appear to do so because of social pressure either by their own households or by the community at large. Lindley (2009) looks at Somali refugees 
in London, finding similar evidence that while many do remit, it seems less because of a pre-migration strategy to diversify income and more because of posthoc considerations for those left behind and what Riak Akuei (2005) calls 'unforeseen burdens'.

Table 11: Theoretical relationships

\begin{tabular}{|c|c|c|c|c|}
\hline Motivation & $\begin{array}{c}\text { Pure } \\
\text { Altruism }\end{array}$ & $\begin{array}{c}\text { Pure } \\
\text { Self-Interest }\end{array}$ & \multicolumn{2}{|c|}{$\begin{array}{c}\text { Tempered Altruism/ } \\
\text { Enlightened Self-Interest }\end{array}$} \\
\hline Description & $\begin{array}{c}\text { Utility derived } \\
\text { from household } \\
\text { well-being }\end{array}$ & $\begin{array}{l}\text { Aspirations to } \\
\text { inherit or } \\
\text { investment in } \\
\text { assets }\end{array}$ & Repayment & Co-insurance \\
\hline Migrant Income & + & + & + & - \\
\hline HH Income & - & + & $+/-$ & - \\
\hline HH Size & + & & & \\
\hline $\begin{array}{l}\text { Negative Shock } \\
\text { to HH Income }\end{array}$ & + & & & + \\
\hline $\begin{array}{l}\text { Migrant Intent } \\
\text { to Return }\end{array}$ & & + & & \\
\hline $\begin{array}{l}\text { Migrant Risk } \\
\text { Level }\end{array}$ & & & & + \\
\hline $\begin{array}{l}\text { Multiple } \\
\text { Migrants }\end{array}$ & - & & & \\
\hline Time Abroad & + , then - & & - & \\
\hline
\end{tabular}

Overall, it is clear in reviewing the literature that no generalized empirical finding emerges given the considerable differences in analytical approach and migration context under study. And while it appears refugees may be less inclined to send remittances as part of an explicit household strategy, this may not be the case for those not officially considered refugees but are still in essence compelled to leave their place of origin due to insecurity or economic uncertainty. In this regard it is important to keep in mind the fine line between voluntary and involuntary movement, which is arguably finer still in an unstable setting like that of Afghanistan. 


\subsection{Methodology}

\section{Empirical Approach}

Our main objective is to highlight the relationship between remittance behavior and an implicit risk-coping household arrangement, indicated by debt-financed migration. The empirical strategy therefore incorporates identification at both the extensive and intensive margin, and includes a range of individual and household characteristics that have been recognized in the literature to likely influence remittance behavior. The basic equation of interest expressing remittance behavior is:

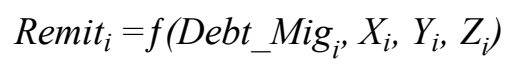

where $D e b t_{-} M i g_{i}$ indicates whether migration was financed by taking on a formal or informal loan from family and friends; $X_{i}$ indicates characteristics of the individual migrant; $Y_{i}$ indicates characteristics of the receiving household at origin; and $Z_{i}$ indicates control variables including migrant destination, ethnicity, district type and province.

In estimating this equation however, it is necessary to take into account that a substantial portion of our sample, 35 percent, do not remit. Therefore, because the distribution of our dependent variable, remittance behavior, is both of a discrete and continuous nature an OLS estimation would lead to biased and inconsistent results. In order to deal with this censored dependent variable we employ a zerocensored tobit model expressed by the following equation:

$$
\text { Remit }_{i}=\alpha_{0}+\beta_{1} \text { Debt_Mig }_{i}+\beta_{2} X_{i}+\beta_{3} Y_{i}+\beta_{4} Z_{i}+u_{i}
$$

where:

$$
\begin{aligned}
& \text { Remit }_{i}=\max \left(0, \text { Remit }_{i}\right) \\
& u_{i} \sim N\left(0, \sigma^{2}\right) .
\end{aligned}
$$

As indicated, the standard tobit model assumes linearity of the latent variable and censors the amount remitted to equal zero if the migrant does not remit. While another option is to use a two-step Heckman selection model, there is little theoretical or empirical evidence to assume different factors influence the 
propensity to remit and the amount remitted, making this type of specification highly sensitive to identification exclusion (Gubert, 2002; Amuedo-Dorantes \& Pozo, 2006). The zero-censored tobit model, on the other hand, allows the same covariates to influence both functions while assuming normality and homoscedasticity of the residuals.

\section{Sample}

The data used in this analysis originates from the household survey collected for the IS Academy 'Migration \& Development: a World in Motion' project. Table 12 provides the summary statistics of our sample, including the mean and standard deviation of both outcome variables along with migrant and household characteristics. A total of 210 migrants aged 15 and older were identified as living abroad for at least two months at the time of survey. For our purposes, just over half of all migrants, 53 percent, financed their journey through an informal loan or gift. Regarding remittances, 65 percent remitted within 12 months of the survey taking place, sending a median total amount of 696 USD. We find no statistical difference in terms of remittance behavior based on whether the migration was debt-financed or not.

As for the migrant characteristics, we find that the vast majority are sons of the household head while most others are brothers. Correspondingly, only about a third of the entire sample is married and the average age is 25 years. Around one in five of all migrants have completed secondary education, however nearly half are employed at destination. Finally, the average time abroad is around two years, and the most typical destination country is Iran. Comparing those migrants who financed their migration through informal debt and those that did not, we only find a statistically significant difference when Pakistan is the destination country.

Turning to household characteristics of the migrant, the average monthly household income per capita is 25 USD. The average household size is nearly nine members, while only around 35 percent of households have more than one member abroad resulting in an overall average of less than one. Most households in our sample are of Tajik ethnicity, and around the same amount live in urban and rural district types while Herat is the most common province. Again comparing across 







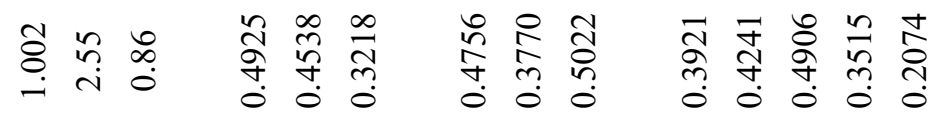

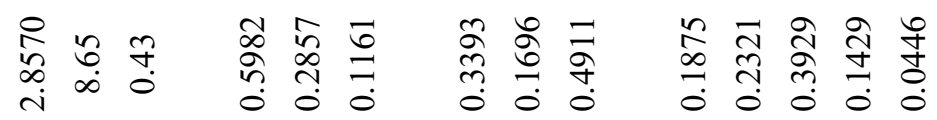

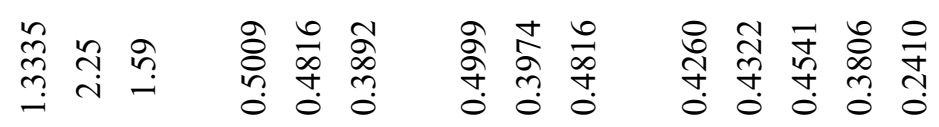

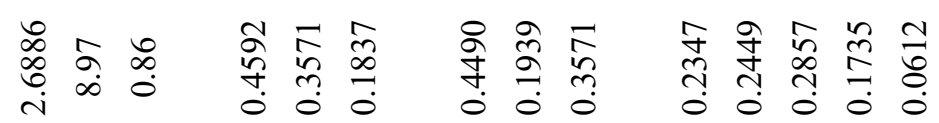

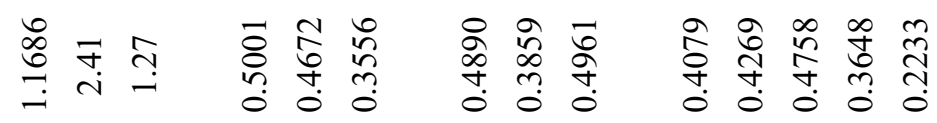

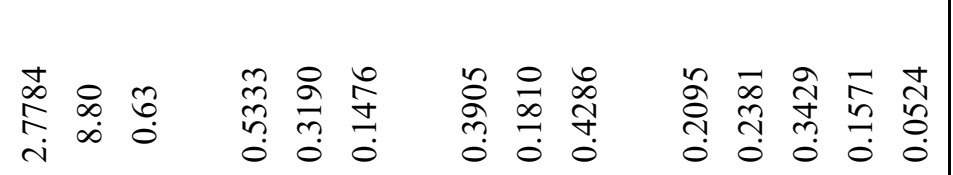




sub-groups, we only find statistically significant differences regarding the number of other migrants from the same household, and when Tajik is the ethnicity of the household.

Beyond those factors to be used in our empirical model, we also have basic information regarding the channel by which remittances were sent, stated purpose and regularity which helps to provide context. Of those migrants that transferred money home, the overwhelming majority, 83 percent, did so through an informal channel (e.g. friend, relative, shopkeeper, call house or hawaladar), while the remaining 17 percent sent money through a formal institution (e.g. bank or money transfer operator). This information is in line with what Hanifi (2006) found in his study on the Afghan diaspora in the US, where selected clients favored sending money through the hawala system, even though a few simultaneously maintained and used formal bank accounts. Furthermore, 56 percent of our sample indicated they sent money home without any particular reason in mind, while 25 percent did so to be spent on daily needs. The remaining responses listed for sending money include for ceremonies like wedding or funerals, formal debt payments and social services like healthcare and education. As for regularity, 10 percent of migrants sent money every month, 38 percent every six months, 28 percent every year and 25 percent irregularly.

\subsection{Results}

Table 13 provides the estimates of the tobit model for remittance behavior over the past year prior to enumeration. We report the marginal effect of both the probability of remitting and the amount sent if remitting, along with robust standard errors. As a matter of parsimony, certain controls including destination country, ethnicity, district type and province used in the model are not reported.

Looking first at our principal variable of interest, we notice remittance behavior is decreasing with debt-financed migration and the result is statistically significant at the 10 percent level. Indeed, those migrants who received an informal loan or gift to help pay for their trip are on the margin eight percent less likely to send remittances in the first place. And when they do send, the level of remittances is 0.59 less of the log total amount. This finding runs counter to the hypothesis that remittances may be part of a risk-diversifying strategy which involves debt- 
financed migration. While this may indicate debt-financed migrants are simply less capable of sending remittances because they originate from poorer households in the first place, a simple mean difference test of household income between the groups shows no statistically significant difference as reported in Table 12.

Table 13: Marginal effect of remittance behavior

\begin{tabular}{|c|c|c|}
\hline & Probability of Remitting & $\overline{\text { Amount Sent (if }>0 \text { ) }}$ \\
\hline \multicolumn{3}{|l|}{ Migrant Characteristics } \\
\hline \multirow[t]{2}{*}{ Debt-Financed Migration } & $-0.0761^{*}$ & $-0.5851^{*}$ \\
\hline & $(0.0431)$ & $(0.3356)$ \\
\hline \multicolumn{3}{|l|}{ Household Position } \\
\hline \multirow[t]{2}{*}{ Household Head } & 0.1208 & 1.3494 \\
\hline & $(0.0964)$ & $(1.6369)$ \\
\hline \multirow[t]{2}{*}{ Son of Head } & $0.3804 * *$ & $2.2496 * *$ \\
\hline & $(0.1778)$ & $(0.8782)$ \\
\hline \multirow[t]{2}{*}{ Brother of Head } & $0.1788 * *$ & 1.9873 \\
\hline & $(0.0865)$ & $(1.4153)$ \\
\hline \multirow[t]{2}{*}{ Married } & -0.0150 & -0.1119 \\
\hline & $(0.0662)$ & $(0.4893)$ \\
\hline \multirow[t]{2}{*}{ Age } & 0.0027 & 0.0202 \\
\hline & $(0.0151)$ & $(0.1145)$ \\
\hline \multirow[t]{2}{*}{ Age Squared } & 0.0000 & 0.0003 \\
\hline & $(0.0002)$ & $(0.0017)$ \\
\hline \multirow[t]{2}{*}{ Secondary Education } & 0.0104 & 0.0804 \\
\hline & $(0.0669)$ & $(0.5282)$ \\
\hline \multirow[t]{2}{*}{ Employed } & $0.2100 * * *$ & $1.6098 * * *$ \\
\hline & $(0.0677)$ & $(0.4873)$ \\
\hline \multirow[t]{2}{*}{ Time Abroad } & $0.2466^{* * *}$ & $1.8686^{* * *}$ \\
\hline & $(0.0512)$ & $(0.3240)$ \\
\hline \multirow[t]{2}{*}{ Time Abroad Squared } & $-0.0277 * * *$ & $-0.2097 * * *$ \\
\hline & $(0.0070)$ & $(0.0473)$ \\
\hline \multicolumn{3}{|l|}{ Household Characteristics } \\
\hline \multirow[t]{2}{*}{ Log of Household Income } & $-0.0761 * * *$ & $-0.5767 * * *$ \\
\hline & $(0.0207)$ & $(0.1437)$ \\
\hline \multirow[t]{2}{*}{ Household Size } & $0.0229 * *$ & $0.1734 * *$ \\
\hline & $(0.0109)$ & $(0.0780)$ \\
\hline \multirow[t]{2}{*}{ Number of Other Migrants } & $-0.0851 * *$ & $-0.6446 * * *$ \\
\hline & $(0.0327)$ & $(0.2320)$ \\
\hline Observations & 210 & \\
\hline Uncensored Observations & 136 & \\
\hline Adj. R-Squared & 0.1246 & \\
\hline
\end{tabular}


Regarding those characteristics of the migrant which are statistically significant, we observe sons of the household head are 38 percent more likely to send money home and send 2.25 more of the log total amount. Similarly, brothers of the household head have a higher propensity to remit, yet there is no statistical significance in terms of amount. Not surprisingly remittance behavior for those migrants who are employed abroad is increasing, even though factors related to earnings potential including age and educational level are statistically insignificant. However, this may simply be a product of the type of employment Afghan migrants are likely to be engaged in while abroad. Lastly, the relationship with duration of time abroad appears to follow an inverted-U curve, with migrants early on showing an increasing propensity to remit at a higher level, before tapering off in the long run as indicated by the squared term.

As for household characteristics, we observe that a higher per capita income is associated with a lower propensity to remit by the migrant at a lower level, while in a similar vein larger households are more likely to receive remittances and at a higher level. Additionally, remittance behavior is decreasing with the number of other migrants from the same household also abroad, with the likelihood of sending remittances falling by nine percent for each additional migrant while the absolute level declines 0.64 of the log total amount.

\subsection{Conclusion}

In this study, our goal has been to unpack the motivations behind remittance behavior of Afghan migrants by utilizing the way in which migration is financed as a discriminating factor. Our conjecture is that if remittances are sent as part of a household risk-diversifying strategy based on an implicit contractual agreement, then we should see a positive relationship between remittance behavior and whether the costs of migration are covered by receiving a loan or gift. No such evidence however is found in the results of our empirical analysis. On the contrary, a debt-financed migrant is in fact less likely to send remittances and to send less in absolute terms when remitting.

What is more, the effects of certain individual and household characteristics of interest are in line with what we would expect if altruism is the dominating explanation. Aside from the fact that remittance behavior is increasing with 
migrant employment and household size and decreasing with household income, relationships which by themselves fail to unambiguously explain remittances through altruism, the fact that remittance behavior is decreasing in the presence of more migrants from the same household indicates altruistic motivations. Furthermore, the inverted-U relationship regarding time abroad suggests remittance behavior increases in the early stages abroad as migrants adapt to their environment and increase their potential to earn, and only later declines as social contact with those at origin begins to fade.

Even though we do not find evidence that Afghan migrants in our sample send remittances as part of a household risk-coping arrangement, this is not to say that migration of a household member in and of itself is not part of any such strategy. Given the realities of the situation in Afghanistan, sending a household member abroad may be less about having an alternative source of income and more about having an alternative location to escape towards if the security situation takes a turn for the worse. Such a thought is particularly relevant in light of the recent political and security transitions, and the understandable concern for the stability of the country.

In addition, given the limited number of remittance senders available in our full dataset it is necessary to reflect on these results with caution. In particular, the potential for households to withhold true information regarding receipt of remittances may be high in such an environment. While we find no evidence of systematic under-reporting, we cannot entirely rule out attrition bias in our results. Nevertheless, we believe even the presence of under-reporting should not fundamentally alter the results found in the analysis. 


\section{Works Cited}

Aga, G. A., Eigen-Zucchi, C., Plaza, S., \& Silwal, A. R. (2013). Migration and Development Brief 20. Migration and Remittances Unit, Development Prospects Group, World Bank.

Agarwal, R., \& Howoritz, A. W. (2002). Are international remittances altruism or insurance? Evidence from Guyana using multiple-migrant households. World Development, 30(11), 2033 - 2044.

Al-Ali, B., Black, R., \& Koser, K. (2001). The Limits to 'Transnationalism': Bosnian and Eritrean Refugees in Europe as Emerging Transnational Communities. Ethnic and Racial Studies, 24(4), 578 - 600.

Amuedo-Dorantes, C., \& Pozo, S. (2006). Remittances as insurance: evidence from Mexican immigrants. Journal of Population Economics, 19(2), 227 - 254.

Batistas, C., \& Umblijs, J. (2014). Do Migrants Send Remittances as a Way of Self-Insurance? Evidence from a Representative Immigrant Survey. (IZA Discussion Paper 7984). Institute for the Study of Labor.

Brown, R. P. (1997). Estimating Remittance Functions for Pacific Island Migrants. World Development, 25(4), 613 - 626.

Carling, J. (2008). The determinants of migrant remittances. Oxford Review of Economic Policy, 24(3), 582 - 599.

Clemens, C., \& Ogden, T. (2013). Migration as a Strategy for Household Finance: A Research Agenda on Remittances, Payments, and Development. (Working Paper 10/2013). Financial Access Initiative, New York University.

Collective for Social Science Research (CSSR). (2006). Afghans in Pakistan: Broadening the Focus. (AREU Briefing Paper). Afghanistan Research and Evaluations Unit (AREU).

de Haas, H. (2010). Migration and Development: A Theoretical Perspective. International Migration Review, 44(1), 227 - 264.

de la Briere, B., de Janvry, A., Lambert, S., \& Sadoulet, E. (1997). Why do Migrants Remit? An Analysis for the Dominican Sierra. (FCND Discussion Paper 37). Food Consumption and Nutrition Division, International Food Policy Research Institute.

Gubert, F. (2002). Do migrants insure those who stay behind? Evidence from the Kayes area (Western Mali). Oxford Development Studies, 30(3), 267 - 287. 
Hagen-Zanker, J., \& Siegel, M. (2007). The Determinants of Remittances: A Review of the Literature. (MGSoG Working Paper 003). Maastricht Graduate School of Governance.

Hanifi, S. M. (2006). Material and Social Remittances to Afghanistan. In C. Westcott \& J. Brinkerhoff, Converting Migration Drains into Gains: Harnessing the Resources of Oversees Professionals. Manila: Asian Development Bank.

Harris, J. R., \& Todaro, M. P. (1970). Migration, Unemployment and Development: A Two-Sector Analysis. American Economic Review, 60, $126-142$.

Holst, E., \& Schrooten, M. (2006). Migration and Money. What Determines Remittances? Evidence from Germany. (Discussion Paper 566). German Institute for Economic Research.

Koser, K. (2014). Transition, Crisis and Mobility in Afghanistan: Rhetoric and Reality. Geneva: IOM.

Lindley, A. (2008). Conflict-Induced Migration and Remittances: Exploring Conceptual Frameworks. (Working Paper Series No. 47). Refugee Studies Centre, Oxford Department of International Development, University of Oxford.

Lindley, A. (2009). The Early-Morning Phonecall: Remittances from a Refugee Diaspora Perspective. Journal of Ethnic and Migration Studies, 35(8), $1315-1334$.

Lucas, R., \& Stark, O. (1985). Motivations to Remit: Evidence from Botswana. Journal of Political Economy, 93(5), 901 - 918.

Massey, D. S., Arange, J., Hugo, G., Kouaouci, A., Pelligrino, A., \& Taylor, J. E. (1993). Theories of international migration: A review and appraisal. Population and Development Review, 19, 431 - 466.

Monsutti, A. (2004). Cooperation, Remittances, Kinship among the Hazaras. Iranian Studies, 37(2), 219 - 240.

Monsutti, A. (2006). Afghan Transational Networks: Looking Beyond Repatriation. (Synthesis Paper Series). Afghanistan Research and Evaluation Unit (AREU).

Monsutti, A. (2008). Afghan Migratory Strategies and the Three Solutions to the Refugee Problem. Refugee Survey Quarterly, 27(1), 58 - 73. 
Naufal, G. S. (2008). Why Remit? The Case of Nicaragua. (IZA Discussion Paper 3276). Institute for the Study of Labor.

Osili, U. O. (2007). Remittances and Savings from International Migration: Theory and Evidence Using a Matched Sample. Journal of Development Economics, 83(2), 446 - 465.

Pleitez-Chavez, R. A. (2004). Remittances as a strategy to Cope with Systematic Risk: Panel Results from Rural Households in El Salvador. Ph. D. dissertation. Department of Agricultural, Environmental, and Develompent Economics, Ohio State University.

Rapaport, H., \& Docquier, F. (2006). The Economics of Migrants Remittances. In S. Kolm, \& J. M. Ythier, Handbook $f$ Economics of Giving, Altruism and Reciprocity. Amsterdam: Elsevier/ North-Holland.

Riak Akuei, S. (2005). Remittances as Unforeseen Burdens: The Livelihoods and Social Obligations of Sudanese Refugees. (Global Migration Perspective 18). Global Commission of International Migration.

Stark, O., \& Bloom, D. E. (1985). The New Economics of Labor Migration. American Economic Review, 75(2), 173 - 178.

Taylor, J. E., \& Dyer, G. A. (2009). Migration and the Sending Economy: A Disaggregated Rural Economy-Wide Analysis. Journal of Development Studies, 45(6), 966 - 989.

Vargas-Silva, C. (2006). The Determinants of International Remittances: Evidence from the Legalized Population. Academy of Economics and Finance Papers and Proceedings, 30, 333 - 335. 


\section{Chapter 4}

\section{The Long-term Consequences of Displacement: Measuring Differences in Education \& Nutrition $^{13}$}

\subsection{Introduction}

In 2015, the number of people forcibly displaced worldwide reached a high of 65.3 million individuals (UNHCR, 2016). While such a statistic usually brings to mind the plight of international refugees spread across the globe, nearly two-thirds, or 38.2 million individuals, are displaced within their own countries (IDMC, 2015). Moreover, there is the general recognition that in most cases displacement, both externally and internally, is protracted over many years, if not decades, with little chance for immediate resolution (Loescher \& Milner, 2009). Taking this into consideration, it is not the immediate, short-term effects that should be of sole concern, but also the long-term consequences which may be especially detrimental to the already fragile development potential of those countries most affected.

Over the years an extensive body of literature has explored the long-term consequences of conflict, many looking at the destruction of human capital during childhood given its potential to severely reduce welfare throughout one's life (Akresh \& de Walque, 2008; Bundervoet et al., 2008; Blattman \& Annan, 2010; Shemyakina, 2011; Akresh et al., 2011; Leon, 2012; Justino et al., 2013). Within this field of study, displacement is acknowledged as a clear channel through which war may have an impact on human capital formation (Justino, 2011). Still, only recently has there been any scholarly work on the effects of displacement in particular, in contrast to war in general (Fiala, 2009; Fiala, 2012; Eder, 2013; Oyelere \& Wharton, 2013; Verwimp \& Van Bavel, 2013). It is within this still

\footnotetext{
${ }^{13}$ This chapter is based on: Loschmann, C. (forthcoming). Taking the Long View: The Consequences of Displacement for Children in Afghanistan. In M. O. Ensor \& E. M. Goździak (eds.), Children and Forced Migration: Durable Solutions during Transient Years. Palgrave Macmillan.
} 
relatively unexplored space that this study aims to make a contribution, using a unique dataset for the (post-) conflict context of Afghanistan.

This chapter investigates the long-term consequences of conflict and displacement in Afghanistan by inquiring how the younger generations within displaced households may fare in their particular circumstances. More specifically, we compare the differences in outcomes arguably crucial for the healthy development of children between households that have experienced internal displacement and those that have not. As a way to infer future livelihood prospects of the child, these outcomes relate to human capital formation concentrating on both education and nutrition. The analysis relies on cross-sectional data from a household survey collected across Afghanistan in late 2012, which allows for exogenous identification of households that were involuntarily displaced due to conflict, insecurity, persecution or natural disaster. While data collection was conducted with a purposeful eye toward returning refugees, the prevalence of internally displaced households in the sample allows for further consideration of this uniquely vulnerable group in comparison to those households which never moved.

In looking at the effects of displacement on human capital formation, Afghanistan makes for an interesting case study for two fundamental reasons. First, the instability that has plagued the country since the late 1970s has led to one of the worst occurrences of forced migration in recent memory. Internal displacement during this time has ebbed and flowed depending on the general level of insecurity, but more recently a renewed insurgency has resulted once again in a marked increase in the number of people driven from their homes. The latest approximation for end-of-year 2014 puts the number of individuals who are internally displaced above 805,000, a notable rise from a low of 129,000 in 2006 (UNHCR, 2015). Moreover, given the political changes in 2014 including presidential elections along with the drawdown of international forces, there is ample uncertainty about the stability of the country looking forward. This suggests further movement is highly likely and may already be occurring in anticipation of heightened insecurity. Nevertheless, despite the high occurrence of displacement in the present day and likelihood that it will persist into the near future, there still exists an apparent lack of understanding pertaining to core protection and assistance needs which may help both national and international organizations better serve this at risk sub-population (Samuel Hall Consulting, 2012). 
Relating to assistance needs, the second fundamental factor concerns the level of progress in Afghanistan in regards to both education and nutrition. Even though modest gains have been made since the last evaluation of its kind, the most recent National Risk and Vulnerability Assessment (NRVA) for 2011/2012 reports failings when it comes to both school enrollment and food security. For the former, only around a quarter of school-aged girls and under half of school-aged boys are enrolled in secondary education. For the latter, around a third of the total population has insufficient caloric intake and nearly a fifth consumes too little protein, "a deficiency which particularly affects the nutrition of children under five (CSO, 2014, p. xviii). As the demographic makeup of the country characterized by one of the youngest age structures in the world evolves in the coming years, the problems associated with low human capital formation will only complicate an already precarious socio-economic situation. If Afghanistan is going to strike a path towards recovery after years of instability, greater investment in the future generations, especially for those in particularly vulnerable circumstances, is indispensable.

The analysis ultimately finds strong evidence that displacement leads to greater food insecurity and lower dietary diversity for those households. In particular, a displaced household is 17 percent less likely to have eaten meat in the week prior to the survey, and those displaced households that had eaten meat ate 30 percent less in comparison to their non-displaced counterparts. Moreover, there is indication that displacement has a negative effect on school attendance, not only for all children but also when differentiating by gender. These last estimates, however, are not robust to the inclusion of location-based controls. It seems we can deduce then that the dynamics within the communities of displacement are more likely to influence educational outcomes regardless of whether the household is displaced or not. This may be due the lack of local services within the community (e.g. schools), or perhaps areas receiving the displaced are poorer in general resulting in a substitution of schooling for income-generating activities.

The remainder of this chapter is structured as follows. The next section provides an outline of the theoretical considerations and past evidence related to the consequences of conflict and displacement, with emphasis on the education and nutrition of children. We then provide an overview of our methodology including further information about our empirical approach along with the sample. We 
finally present our results and conclude with a discussion concerning the limitations of our analysis and policy relevance.

\subsection{Literature Review}

Interest in understanding the consequences of armed conflict within the fields of political science and development economics has blossomed over the years. Conceptually though, the long-term effects on development are ambiguous. From a macro-level perspective, there is the expectation following neoclassical growth models that after fighting subsides a country will quickly recover back to its steady state growth rate (Blattman \& Miguel, 2010). Even though the duration of recovery may vary, there exists empirical evidence mostly supporting such a conjecture in a diverse set of environments ranging from post-war Japan (Davis \& Weinstein, 2002), West Germany (Brakman et al., 2004), Rwanda (Justino \& Verwimp, 2006) and Vietnam (Miguel \& Roland, 2011) along with cross-country analyses (Cerra \& Saxena, 2008; Chen et al., 2008).

On the other hand however, more recent poverty trap and endogenous growth models suggest a drawn-out recovery in the wake of conflict especially when taking into account asymmetric destruction of physical and human capital. As Blattman \& Miguel (2010, p. 38) convey, "the disproportionate loss of human capital in war results in slower economic growth and recovery than the destruction of physical capital, during the transition back to steady state growth". Moreover, violent conflict is likely to undermine the social and institutional foundations of a country, which could have long-lasting and possibly less apparent consequences for economic and political development. Even though empirical evidence highlighting such a complex relationship is less clear-cut given the inherent measurement difficulties, a few novel approaches provide valuable insight. Miguel et al. (2011), for example, use fouls committed in European soccer to show how a player's exposure to civil conflict influences actual socio-cultural norms towards violence. Alternatively, Dell (2012) argues that insurgent activity during the Mexican Revolution in the early $20^{\text {th }}$ century may well explain why certain municipalities in present-day Mexico are substantially poorer and have significantly less turnover when it comes to local political representation. More tangible still than these deeply entrenched historical effects, war may also simply curtail the ability of local civil institutions, like schools or health clinics, from 
fulfilling their critical functions. To assess this, however, it is necessary to focus not on the macro-level effects but rather the micro-level consequences for individuals and entire households.

During times of conflict it is usually the civilian population which incurs the greatest burden. With this in mind, the majority of the micro-level literature considers the effects of fighting on human capital accumulation amongst noncombatants, touching on topics like employment, education and health. It is natural then that questions arise concerning how children in particular are affected by war given that investment in their human capital is most at stake. Indeed, the loss of human capital during childhood may have severe long-run effects on individual and household welfare as it reduces their future livelihood prospects (Justino, 2011). Looking at the effect on educational attainment, a number of studies over a range of settings provide evidence that children exposed to violence acquire fewer years of schooling (Akresh \& de Walque, 2008; Swee, 2009; Chamabargwala \& Moran, 2011; Shemyakina, 2011; Leon, 2012; Justino et al., 2013). While not all are directly comparable given differences in context and empirical approach, certain general findings seem to emerge including the disproportionate impact on secondary schooling as well as differences based on gender. Just as important, there are also those studies that document the negative effect on children's health outcomes (Alderman et al., 2006; Bundervoet et al., 2008; Akresh et al., 2011; Minoiu \& Shemyakina, 2014). In general, they provide evidence that exposure to fighting results in worse nutrition as well as a lower height-for-age. While there appears to be clear indication regarding the negative consequences of armed conflict for those factors related to human capital accumulation, the mechanism through which this effect takes place is not obvious.

Clearly many families confronted with violence in their communities respond by fleeing together in search of safety, or by making arrangements for certain household members like children to find sanctuary elsewhere. Displacement, therefore, is one potential channel through which violent conflict has an influence on a household's well-being and human capital accumulation (Justino, 2011). Empirical research looking into the economic consequences of forced migration, including those regarding the impact on education and health, is relatively new with most studies emerging within the last five years (see, e.g., Ruiz \& VargasSilva, 2013 for a detailed review). Oyelere and Wharton (2013), for example, 
attempt to establish causal evidence for the effect of conflict on education accumulation and enrollment gaps for children of internally displaced families in Colombia. After applying various econometric techniques in order to minimize any potential omitted variable and selection bias, their results indicate a significant education accumulation gap as well as a lower rate of enrollment at the secondary level for internally displaced households. In the case of Burundi, Verwimp and Van Bavel (2013) similarly find that the frequency of displacement leads to a decrease in the probability of completing primary school for both boys and girls. Looking at forced displacement in northern Uganda, Fiala (2012) finds that more affluent displaced households have significantly less educational attainment which suggests a strategic shift of human to physical capital investment. Alternatively, Eder (2013) uses ethnic divisions during the Bosnian War as a natural experiment to determine the educational outcomes of children of displaced parents. Even though no significant difference in school enrollment is found, displaced households are shown to spend significantly less on their child's education at both the primary and secondary level. When it comes to health, Fiala (2009), again in the case of northern Uganda, shows that displacement is associated with a significant decrease in the consumption of meat, an indicator of dietary diversity and nutrition in general.

Taken altogether, the literature pertaining to the consequences of violent conflict and internal displacement unsurprisingly indicates a generally negative impact on those factors related to human capital accumulation for the civilian population. While the micro-level effect is detrimental for individual and household welfare for years to come, it also has severe implications at the macro-level via productivity loss and as a consequence stalled economic growth. We now turn towards the specific case of Afghanistan where, despite clear relevance, to the best of our knowledge no similar inquiry has been considered.

\subsection{Methodology}

\section{Empirical Approach}

Considering the structure of the outcomes of interest, to be discussed in further detail below, we apply two distinct models to estimate the effect of displacement. On the one hand, we employ a multinomial logit model when considering the 
outcomes school attendance and food security, as each is a categorical variable with various response possibilities. This can be formally expressed as:

$$
\operatorname{Pr}\left(y_{i}=j\right)=\frac{e^{\beta_{j} x_{i}}}{\sum_{j=1}^{K} e^{\beta_{j} x_{i}}}
$$

where $y_{i}$ represents category $j$ for either school attendance or food security of household $i, x_{i}$ indicates the vector of household-level covariates influencing school attendance or food security, and $\beta_{j}$ represents the vector of choice-specific coefficients.

On the other hand, because the outcome dietary diversity is of both a discrete and continuous nature due to the fact that nearly half of households in our sample reported unable to eat meat over the previous week, we employ a zero-censored tobit model expressed by the following equation:

$$
Y_{i}=\alpha_{0}+\beta_{1} I D P_{i}+\beta_{2} X_{i}+u_{i}
$$

where,

$$
\begin{gathered}
Y_{i}=\max \left(0, Y_{i}\right) \text {, and } \\
u_{i} \sim N\left(0, \sigma^{2}\right) .
\end{gathered}
$$

Here $I D P_{i}$ is a dummy variable taking the value of one if the household is internally displaced, $X_{i}$ again represents household-level covariates, and $u_{i}$ is the error term. In principle, the zero-censored tobit model takes into account the linearity of the latent variable for those observations not equal to zero, while also assuming normality and homoscedasticity of the residuals.

\section{Sample}

This study relies on data collected for the independent evaluation of the UNHCR shelter assistance program. Because the objective of the survey was to capture information for return migrants and IDPs, the questionnaire allows for direct identification of internally displaced households in comparison to those who have never moved. Moreover, because respondents were asked two distinct questions about why they decided to move from their community of origin and why they 
decided to move to their current place of residence, we are able to identify households that were involuntarily displaced due to conflict, insecurity, persecution or natural disaster - arguably exogenous shocks resulting in minimal choice in the decision to move $^{14}$ - and who chose their destination location without consideration for the outcomes in question (e.g. services like education, food and health). This allows for greater distinction between involuntary and voluntary movement as well as exogenous location choice. Ultimately, our sample is made up of 1,020 household-level observations of which 40 percent are considered involuntarily and exogenously internally displaced. Figure 4 illustrates where these internally displaced households are located around the country by province.

Even though we only take into account involuntary migration, it is still possible that some households may be systematically more exposed to violence, and therefore displacement, given inherent characteristics (e.g. wealth levels prior to displacement) leading to inconsistent estimates (Kondylis, 2010). While we cannot fully account for such selection bias using advanced econometric techniques due to the limitations of our dataset, we believe our estimates should be considered lower bounds for two reasons. First, one could readily suppose local violence in general is likely to be targeted towards those wealthier members of the community as they arguably have more local authority. However, in Afghanistan there is little evidence to support such a conjecture as much of the violence has been noticeably indiscriminate against the civilian population (see, e.g., Human Rights Watch, 2007). Our own data corroborates such a lack of targeted violence, as only 16 percent of those households considered internally displaced are so because of personal, family or ethnic persecution while the majority of households, 83 percent, are so because of general insecurity and conflict. Nonetheless, although we cannot categorically discount targeting, supposing true would mean displaced households should have been systematically better off before migration relative to non-displaced households in terms of general well-being. Second, the migration

\footnotetext{
${ }^{14}$ Any displacement in general can be considered involuntary. However, restricting our sample to those who moved due to these four reasons helps strengthen our argument that displacement in this case is influenced by exogenous forces leaving less potential for selection bias. The other reasons for displacement include: no land or housing, no access to arable or pastoral land, no access to food and water, no access to health services, no access to education and no access to employment opportunities.
} 
journey itself, even internally, is not without cost. Therefore similarly if those who migrated were able to assume such costs while those who stayed behind were not, one can assume that displaced households were again better off before migration took place. As such, our estimates, if in fact imprecise, should in principle be underestimating any true effect that shows a negative difference between displaced and non-displaced households.

Figure 4: Location of internally displaced households, by province



Note: For exact figures, see Table A4.1 in the appendix.

Given the goal here is to measure the extent to which internal displacement has an effect on livelihood prospects later on in life, we focus on child-related outcomes related to human capital formation, namely education and nutrition. Both outcomes are widely recognized as fundamental determinants of future well-being and have been the focus of myriad studies in the development literature (see, e.g., Alderman et al., 2006; Rosenzweig, 2010). Regarding education, our outcome of interest is the categorical variable school attendance of school-aged children differentiated by whether no children attend school, all children attend school or only boys attend 
school ${ }^{15}$. When considering the categorical response of attendance by only male children, keep in mind the respondent had to explicitly specify no attendance by female children present in the household and as such does not include the case where female children are not present. Therefore, households with single gender school-aged children, around six percent of the sample, have the choice of all or no attendance. As for nutrition, our outcomes of interest include the categorical variable food insecurity differentiated by whether the household never has problems satisfying food needs, rarely has problems (one or two times per month) or often has problems (greater than three times per month), and the continuous variable dietary diversity proxied by the number of times the household has eaten meat in the last week.

Table 14 presents summary statistics reporting the mean and standard deviation, not only for the entire sample but also differentiated by whether the household is considered internally displaced or not, including a simple means difference test in the final column. In terms of the outcomes of interest, out of 1,020 respondents who knew whether their school-aged children were in school or not, 35 percent reported no attendance whatsoever. On the other end of the spectrum 41 percent said that all children in the household attended school, and 20 percent reported only boys were in school. There is a highly statistically significant difference in responses when comparing non-displaced and displaced households, apart from when the response was only boys attended school.

As for food insecurity, 20 percent of households responded as having no problems satisfying food needs, while some 44 percent rarely had problems (one to two times per month) and another 37 percent often had problems (greater than three times per month). We find non-displaced households were much more likely to never have problems, and displaced households more likely to often have problems. Lastly, the average times households had eaten meat over the prior week indicating dietary diversity is around one, however this masks the fact that 46 percent of our sample reported having eaten no meat over the last week. Between

\footnotetext{
${ }^{15}$ We exclude the category 'only girls attend school' due to the low number of observations. Moreover, we do not consider households where no school-aged children are present.
} 
groups, there is a statistically significant mean difference with non-displaced households eating meat more often than their displaced counterparts.

Table 14: Summary statistics

\begin{tabular}{lllllllll}
\hline \hline & \multicolumn{2}{c}{ Full Sample } & & \multicolumn{2}{c}{ Non-Displaced } & & \multicolumn{2}{l}{ Int. Displaced } \\
& mean & sd & & mean & sd & mean & sd & t-test \\
\hline Outcomes
\end{tabular}

School Attendance:

None

All school-aged

children

Only school-aged boys

Food Insecurity:

Never

Rarely

(1-2 times/month)

Often

(>3 times/month)

Dietary Diversity

(times eaten meat/week)

Household-level

Covariates

Age of respondent

No formal education

Married

Number of children

Disabled

Log of HH income

Received assistance

Ethnicity:

Pashtun

Tajik

Hazara

Other

Location-based Controls

Rural location type

$\begin{array}{llllll}0.3539 & 0.4784 & 0.2946 & 0.4562 & 0.4425 & 0.4973 \\ 0.4078 & 0.4917 & 0.4550 & 0.4984 & 0.3374 & 0.4734 \\ 0.2029 & 0.4024 & 0.2111 & 0.4084 & 0.1907 & 0.3933\end{array}$

$\begin{array}{llllll}0.1951 & 0.3965 & 0.2357 & 0.4248 & 0.1345 & 0.3416\end{array}$

$\begin{array}{llllll}0.4382 & 0.4964 & 0.4239 & 0.4946 & 0.4597 & 0.499\end{array}$

$\begin{array}{llllll}0.3667 & 0.4821 & 0.3404 & 0.4742 & 0.4059 & 0.4917\end{array}$

$\begin{array}{llllll}0.9725 & 1.3221 & 1.1178 & 1.4573 & 0.7555 & 1.0543\end{array}$

$\begin{array}{llllll}37.74 & 14.09 & 37.64 & 14.12 & 37.89 & 14.06\end{array}$

$\begin{array}{llllll}0.8265 & 0.3789 & 0.8200 & 0.3845 & 0.8362 & 0.3706\end{array}$

$\begin{array}{lllllll}0.8510 & 0.3563 & 0.8167 & 0.3872 & 0.9022 & 0.2974\end{array}$

$\begin{array}{lllllll}5.20 & 3.07 & 5.25 & 3.04 & 5.11 & 3.11\end{array}$

$\begin{array}{llllll}0.2225 & 0.4162 & 0.2013 & 0.4013 & 0.2543 & 0.4360\end{array}$

$\begin{array}{lllllll}3.5692 & 0.6106 & 3.5972 & 0.6206 & 3.5275 & 0.5935\end{array}$

$\begin{array}{lllllll}0.4500 & 0.4977 & 0.3797 & 0.4857 & 0.5550 & 0.4976\end{array}$

$\begin{array}{llllll}0.6255 & 0.4842 & 0.6072 & 0.4888 & 0.6528 & 0.4767\end{array}$

$0.0990 \quad 0.2988$

$0.1358 \quad 0.3429$

$0.0440 \quad 0.2054$

$\begin{array}{lllllll}0.0725 & 0.2595 & 0.0835 & 0.2768 & 0.0562 & 0.2307\end{array}$

$\begin{array}{lllllll}0.2029 & 0.4024 & 0.1735 & 0.3790 & 0.2469 & 0.4318\end{array}$

$\begin{array}{llllll}0.7784 & 0.4155 & 0.7005 & 0.4584 & 0.8949 & 0.3071\end{array}$ 


\begin{tabular}{llllllll} 
Province: & & & & & & & \\
Kabul & 0.0520 & 0.2221 & 0.0524 & 0.2230 & 0.0513 & 0.2210 & \\
Parwan & 0.0216 & 0.1453 & 0.0164 & 0.1270 & 0.0293 & 0.1690 & \\
Bamyan & 0.0069 & 0.0826 & 0.0049 & 0.0700 & 0.0098 & 0.0985 & \\
Laghman & 0.0598 & 0.2372 & 0.0917 & 0.2888 & 0.0122 & 0.1100 & $* * *$ \\
Nangarhar & 0.3147 & 0.4646 & 0.4124 & 0.4927 & 0.1687 & 0.3749 & $* * *$ \\
Balkh & 0.0333 & 0.1796 & 0.0491 & 0.2163 & 0.0098 & 0.0985 & $* * *$ \\
Faryab & 0.0725 & 0.2595 & 0.0360 & 0.1865 & 0.1271 & 0.3335 & $* * *$ \\
Jawzjan & 0.0402 & 0.1965 & 0.0524 & 0.2230 & 0.0220 & 0.1469 & $* *$ \\
Sari Pul & 0.0118 & 0.1079 & 0.0180 & 0.1331 & 0.0024 & 0.0494 & $* *$ \\
Kunduz & 0.0245 & 0.1547 & 0.0245 & 0.1549 & 0.0244 & 0.1546 & \\
Takhar & 0.0559 & 0.2298 & 0.0164 & 0.1270 & 0.1149 & 0.3193 & $* * *$ \\
Helmand & 0.0931 & 0.2908 & 0.0409 & 0.1983 & 0.1711 & 0.3771 & $* * *$ \\
Kandahar & 0.0706 & 0.2563 & 0.0491 & 0.2163 & 0.1027 & 0.3039 & $* *$ \\
Paktya & 0.0314 & 0.1744 & 0.0475 & 0.2128 & 0.0073 & 0.0854 & $* * *$ \\
Herat & 0.1118 & 0.3152 & 0.0884 & 0.2841 & 0.1467 & 0.3542 & $* *$ \\
\hline
\end{tabular}

Significance Levels: *0.10, ** $0.05, * * * 0.01$.

Regarding other covariates, we take into account an array of household-level factors including the age of the adult respondent (i.e. household head or spouse), whether they had received any formal education, whether the household head was married, the number of children in the household, whether the household had a physically or mentally disabled member, the log of monthly income per capita and whether they had received formal assistance from a NGO, government or international organization. Furthermore, we control for ethnicity of the household and consider location-based controls including rural location type and province.

Table 14 illustrates the fact that non-displaced and internally displaced households are similar in a number of ways including the fact that most adult respondents have no formal education, they have around the same number of children and similar wealth levels based on the log of monthly income. On the other hand, they differ in that displaced households are slightly more likely to have a married household head, as well as more likely to have received formal assistance. As for ethnicity, the majority of our sample is Pashtun, similar across sub-groups. Moreover, the Tajik are less likely to be internally displaced while 'other' ethnic groups on the 
other hand are more likely. Regarding location, most households in our sample are located in rural areas with this figure noticeable greater for the internally displaced. Lastly in terms of provincial location, internally displaced households appear to be concentrated in much greater numbers than non-displaced households in Faryab, Takhar, Helmand, Kandahar and Herat, while the opposite is true in Laghman, Nangarhar, Balkh, Jawzjan, Sari Pul and Paktya.

\subsection{Results}

We here report the results of all three models depending on the outcome of interest. For the sake of parsimony, we focus solely on the variable of interest, whether the household is internally displaced or not, and indicate if the previously explained household-level covariates and location controls are included in the model specification. The results of all full models can be found in the appendix.

Table 15 presents the estimates for the effect of displacement on school attendance for those school-aged children of the household, reporting the relative risk ratio in comparison to the base category of no school attendance and robust standard errors in parentheses. We find that across both response categories, being a child within an internally displaced household yields a statistically significant and negative result for school attendance when not controlling for location. None of the estimates, however, are robust to the inclusion of location-based controls including whether the household is located in a rural setting along with the specific province of current location. As such, even though there is indication that internal displacement plays a role for school attendance, the relationship is not uniform across all local settings. It seems we can deduce then that the dynamics within the communities of displacement are more likely to influence educational outcomes regardless of whether the household is displaced or not. This may be due the lack of local services within the community (i.e. schools) which is not uncommon throughout Afghanistan, or perhaps areas receiving the displaced are poorer in general resulting in a substitution of schooling for income-generating activities.

Table 16 provides the results for the effect of displacement on food insecurity, again reporting the relative risk ratio in comparison to the base category of never having problems satisfying food needs along with the standard errors in parentheses. Contrary to the former model, here we find robust results across 
model specification that a displaced household has a greater likelihood of being food insecure at both levels, rarely having problems satisfying food needs (1-2 times/month) and often having problems satisfying food needs ( $>3$ times/month). Additionally, when comparing across these two distinct levels of food insecurity we find a displaced household has greater odds of being more food insecure, although this result does not hold once controlling for location. Regardless, our findings paint a clear picture that displaced households are more food insecure than those that never migrated.

Table 15: Relative risk ratio of school attendance

\begin{tabular}{lccc|ccc}
\hline \hline Base: None & \multicolumn{3}{c|}{ All School-Aged Children } & \multicolumn{3}{c}{ Only School-Aged Boys } \\
\hline Int. Displaced & $0.4937^{* * *}$ & $0.4838^{* * *}$ & 0.7608 & $0.6013^{* * *}$ & $0.6008^{* * *}$ & 0.8363 \\
& $(0.0740)$ & $(0.0849)$ & $(0.1628)$ & $(0.1099)$ & $(0.1175)$ & $(0.1976)$ \\
HH-level & No & Yes & Yes & No & Yes & Yes \\
Covariates & & & & & & No \\
Location-based & No & No & Yes & No & Yes \\
Controls & 0.0102 & 0.1158 & 0.1742 & 0.0102 & 0.1158 & 0.1742 \\
\hline Adj. R & 1020 & 1020 & 1020 & 1020 & 1020 & 1020 \\
$\mathrm{~N}$ & & & & & & \\
\hline
\end{tabular}

Significance Levels: ${ }^{*} \mathrm{p}<0.10,{ }^{* *} \mathrm{p}<0.05,{ }^{* * *} \mathrm{p}<0.01$. For full results see Table A4.2 in the appendix.

Table 16: Relative risk ratio of food security

\begin{tabular}{lccc|ccc}
\hline \hline Base: Never & \multicolumn{2}{c|}{ Rarely (1-2 times/month) } & \multicolumn{3}{c}{ Often (>3 times/month) } \\
\hline Int. Displaced & $1.9005^{* * *}$ & $1.9340^{* * *}$ & $2.0554 * * *$ & $2.0895^{* * *}$ & $2.1239 * * *$ & $2.0358^{* * *}$ \\
& $(0.3522)$ & $(0.3836)$ & $(0.4628)$ & $(0.3964)$ & $(0.4434)$ & $(0.4717)$ \\
HH-level & No & Yes & Yes & No & Yes & Yes \\
Covariates & & & & & & No \\
Location-based & No & No & Yes & No & Yes \\
Controls & 0.0080 & 0.0533 & 0.0823 & 0.0080 & 0.0533 & 0.0823 \\
\hline Adj. R & 1020 & 1020 & 1020 & 1020 & 1020 & 1020 \\
$\mathrm{~N}$ & $\mathrm{~N}$ & & & & & \\
\hline
\end{tabular}

Significance Levels: $* \mathrm{p}<0.10,{ }^{* *} \mathrm{p}<0.05, * * * \mathrm{p}<0.01$. For full results see Table A4.3 in the appendix.

Lastly, Table 17 illustrates the effect of displacement on dietary diversity taking into consideration the number of times the household had eaten meat in the week 
prior. Because we are employing a zero-censored tobit model, we report the marginal effects for both the probability of having eaten meat as well as the number of times if the former is greater than zero. Again, our estimates are robust across all model specifications with a displaced household being less likely to having eaten meat and eaten less if so. In particular, in the full model taking into account household-level covariates and location-based controls as indicated in the last column of each, a displaced household is on the margin 17 percent less likely to have eaten meat in the week prior to the survey. And for those displaced households that had eaten meat, they ate 30 percent less in comparison to their nondisplaced counterparts.

Table 17: Marginal effect of dietary diversity

\begin{tabular}{|c|c|c|c|c|c|c|}
\hline \multirow[b]{2}{*}{ Int. Displaced } & \multicolumn{3}{|c|}{ Probability of Eating Meat } & \multicolumn{3}{|c|}{ No. of Times Eating Meat (if >0) } \\
\hline & $\begin{array}{c}-0.1186 \text { *** } \\
(0.0270)\end{array}$ & $\begin{array}{c}-0.1161 * * * \\
(0.0286)\end{array}$ & $\begin{array}{c}-0.1700 * * * \\
(0.0331)\end{array}$ & $\begin{array}{c}-0.2419 * * * \\
(0.0558)\end{array}$ & $\begin{array}{c}-0.2189 * * * \\
(0.0556)\end{array}$ & $\begin{array}{c}-0.2986 \text { *** } \\
(0.0599)\end{array}$ \\
\hline $\begin{array}{l}\text { HH-level } \\
\text { Covariates }\end{array}$ & No & Yes & Yes & No & Yes & Yes \\
\hline $\begin{array}{l}\text { Location-based } \\
\text { Controls }\end{array}$ & No & No & Yes & No & No & Yes \\
\hline Adj. $\mathrm{R}^{2}$ & 0.0058 & 0.0518 & 0.0900 & 0.0058 & 0.0518 & 0.0900 \\
\hline $\mathrm{N}$ & 1020 & 1020 & 1020 & 1020 & 1020 & 1020 \\
\hline
\end{tabular}

Significance Levels: $* \mathrm{p}<0.10,{ }^{* *} \mathrm{p}<0.05, * * * \mathrm{p}<0.01$. For full results see Table A4.4 in the appendix.

\subsection{Conclusion}

The number of individuals worldwide displaced from their homes is at a level not seen since the Second World War. In Afghanistan, decades of conflict have resulted in one of the worst cases of displacement, which is likely to endure into the near future. With this in mind, this study investigates the long-term consequences of conflict and displacement in Afghanistan by inquiring how the younger generations within displaced households may fare in their particular circumstances. More specifically, we compare the differences in child-related outcomes between households that have experienced internal displacement and those who have not. As a way to infer future livelihood prospects of the child, these outcomes relate to human capital formation concentrating on both education and nutrition. 
Our analysis finds strong evidence that displacement leads to inferior nutritional outcomes, with displaced households 17 percent less likely to have eaten meat in the week prior to the survey. For those household that had eaten meat, they consumed 30 percent less in comparison to non-displaced households. As for education, there is indication that displacement has resulted in worse school attendance. These last estimates, however, are not robust to the inclusion of location-based fixed effects, suggesting that the characteristics of the communities are more likely to influence educational outcomes regardless of whether the household is displaced or not. This is likely due the lack of local services like schools or teachers in communities throughout Afghanistan, but especially in rural areas where many of the displaced are located. Indeed, the NRVA report for 2011/2012 makes note of the low absorption capacity of the education system overall, while also highlighting general impediments to school attendance like insecurity and distance to schools (CSO, 2014). Otherwise, it may be that areas commonly receiving the displaced are generally poorer resulting in a substitution of schooling for income-generating activities not only for children of displaced households but for those of non-displaced households as well.

An evident limitation of our analysis is the inability to fully account for endogeneity, namely selection bias of displacement. We consider only those households involuntarily displaced due to conflict, insecurity, persecution or natural disaster - arguably exogenous shocks - and who chose their destination location without consideration for the outcomes in question (e.g. services like education, food and health). Nonetheless, it is still possible that some households may be systematically more exposed to violence, and therefore displacement, given inherent characteristics leading to inconsistent estimates. With this in mind, we believe our estimates should be regarded as lower bounds for two reasons that make it probable displaced households are better off a priori relative to nondisplaced households: local violence, if targeted, is likely targeted towards wealthier members of the community; and the migration journey itself, even internally, is costly. As such, our estimates, if in fact imprecise, should in principle be underestimating any true effect that shows a negative difference between displaced and non-displaced households making them still fundamentally meaningful. 
Another clear drawback is the fact that our analysis is done entirely at the household level. While certain questions from the original survey focused on individuals within the household (e.g. adult respondent's level of education), we lose a level of insight by not having all information at the individual level. For instance, our results for food insecurity pertain to the whole household. However, it is not difficult to imagine a case where intra-household differences in food consumption exist especially between children and adults, or even by gender. Even though cost limitations frequently hamper more detailed data collection at the individual level, future surveys in this still understudied context would be wise to do so.

The overall conclusion that internally displaced households are a vulnerable subgroup within the population at large is not an unexpected revelation. What is salient, however, is the extent to which children of displaced households may be particularly afflicted, and the consequences this may have in the long-term. As such, in the context of Afghanistan there is a real need for further understanding pertaining to protection and assistance needs for this at risk sub-population. Such efforts are already under way as the national government supported by international organizations and NGOs begin to focus more closely on these households in an effort to develop displacement-sensitive programing and policies (see, e.g., Schmeidl et al., 2010; World Bank, 2011; Samuel Hall Consulting, 2012; Brookings, 2013; Samuel Hall Consulting, 2014). What is clear is that such policies need to take into account how best to protect displaced households given their particular needs and vulnerabilities. The study here identifies both food security and dietary diversity as clear problems facing displaced households which can be addressed through coordinated efforts to improve access to markets along with arable land. Moreover, even though we fail to find a robust link between displacement and education in this study, qualitative evidence still points to low levels of school enrollment for IDP children due to the lack of school facilities and the not uncommon practices of child marriage and child labor (Samuel Hall Consulting, 2014). As such, further investment in school facilities where internally displaced households commonly settle, as well as culturally-sensitive information programs about these customary practices may be particularly beneficial. 


\section{Works Cited}

Akresh, R., \& de Walque, D. (2008). Armed Conflict and Schooling: Evidence from the 1994 Rwandan Genocide. (HiCN Working Paper 47). Households in Conflict Network.

Akresh, R., Verwimp, P., \& Bundervoet, T. (2011). Civil War, Crop Failure, and Child Stunting in Rwanda. Economic Development and Cultural Change, 59(4), 777 - 810.

Alderman, H., Hoddinott, J., \& Kinsey, B. (2006). Long Term Consequences of Early Childhood Malnutrition. Oxford Economic Papers, 58(3), 450 - 474.

Blattman, C., \& Annan, J. (2010). The Consequences of Child Soldiering. Review of Economics and Statistics, 92(4), 882 - 898.

Blattman, C., \& Miquel, E. (2010). Civil War. Journal of Economic Literature, $48(1), 3$ - 57.

Brakman, S., Garretsen, H., \& Schramm, M. (2004). The Strategies Bombing of German Cities During World War II and Its Impact on City Growth. Journal of Economic Geography, 4(2), 201 - 218.

Brookings Institution. (2013). Under the Radar: Internally Displaced Persons in Non-Camp Settings. Brookings-LSE Project on Internal Displacement. Washington D.C.: Brookings Institution.

Bundervoet, T., Verwimp, P., \& Akresh, R. (2008). Health and Civil War in Rural Burundi. The Journal of Human Resources, 44(2), 536 - 463.

Central Statistics Office (CSO). (2014). National Risk and Vulnerability Assessment 2011/2012. Afghanistan Living Conditions Survey. Kabul: Central Statistics Office.

Cerra, V., \& Saxena, S. C. (2008). Growth Dynamics: The Myth of Economic Recovery. American Economic Review, 98(1), 439 - 457.

Chamabargwala, R., \& Moran, H. E. (2009). The human capital consequences of civil war: Evidence from Guatemala. The Journal of Development Economics, 94(1), 41 - 61.

Chen, S., Loayza, N. V., \& Reynal-Querol, M. (2008). The Aftermath of War. World Bank Economic Review, 22(1), 63 - 85.

Davis, D. R., \& Weinstein, D. E. (2002). Bones, Bombs, and Break Points: The Geography of Economic Activity. American Economic Review, 92(5), 1269 - 1289. 
Dell, M. (2012). Path Dependence in Development: Evidence from the Mexican Revolution. (Unpublished manuscript). Department of Economics, Harvard University.

Eder, C. (2013). Displacement and Education of the Next Generation: Evidence from Bosnia and Herzogovina. (HiCN Working Paper 152). Households in Conflict Network.

Fiala, N. (2009). The Consequences of Forced Displacement in Northern Uganda. (HiCN Working Paper 65). Households in Conflict Network.

Fiala, N. (2012). The Economic Consequences of Forced Displacement. (HiCN Working Paper 137). Households in Conflict Network.

Human Rights Watch. (2007). The Human Cost: The Consequences of Insurgent Attacks in Afghanistan. Volume 19 (6C). New York: Human Rights Watch.

Internal Displacement Monitoring Centre (IDMC). (2015). Global figures. Retrieved August 1, 2015, from <www.internal-displacement.org $>$.

Justino, P. (2011). Violent Conflict and Human Capital Accumulation. (HiCN Working Paper 99). Households in Conflict Network.

Justino, P., \& Verwimp, P. (2006). Poverty Dynamics, Violent Conflict and Convergence in Rwanda. (HiCN Working Paper 16). Households in Conflict Network.

Justino, P., Leone, M., \& Salardi, P. (2013). Short- and Long-Term Impact of Violence on Education: The Case of Timor Leste. World Bank Economic Review, 28(2), 320 - 353.

Kondylis, F. (2010). Conflict displacement and labor market outcomes in post-war Bosnia and Herzegovina. Journal of Development Economics, 93, 235 248.

Leon, G. (2012). Civil Conflict and Human Capital Accumulation. The Journal of Human Resources, 47(4), 992 - 1022.

Loescher, G., \& Milner, J. (2009). Understanding the Challenge. Forced Migration Review, 33, 9 - 11.

Miguel, E., \& Roland, G. (2011). The long-run impact of bombing Vietnam. Journal of Development Economics, 96, 1 - 15.

Miguel, E., Saiegh, S., \& Satyanath, S. (2011). Civil War Exposure and Violence. Economics \& Politics, 23(1), 59 - 73. 
Minoiu, C., \& Shemyakina, O. N. (2014). Armed Conflict, Household Victimization and Child Health in Cote d'Ivoire. Journal of Development Economics, 108, 237 - 255.

Oyelere, R. U., \& Wharton, K. (2013). The Impact of Conflict on Education Attainment an Enrollment in Columbia: lessons from recent IDPs. (HiCN Working Paper 141). Households in Conflict Network.

Rosenzweig, M. (2010). Microeconomic Approaches to Development: Schooling, Learning, and Growth. Journal of Economic Perspectives, 24(3), 81 - 96.

Ruiz, I., \& Vargas-Silva, C. (2013). The Economics of Forced Migration. Journal of Development Studies, 49(6), 772 - 784.

Samuel Hall Consulting. (2012). Challenges of IDP Protection: Research study on the protection of internally displaced persons in Afghanistan. Kabul: Samuel Hall Consulting.

Samuel Hall Consulting. (2014). Displacement Dynamics: IDP Movement Tracking, Needs and Vulnerability Analysis, Herat and Helmand. Commissioned by the International Organization for Migration (IOM). Kabul: Samuel Hall Consulting.

Schmeidl, S., Mundt, A. D., \& Miszak, N. (2010). Beyond the Blanket: Towards More Effective Protection for Internally Displaced Persons in Southern Afghanistan. Brookings-Bern Project on Internal Displacement and The Liason Office. Washington D. C.: The Brookings Institution.

Shemyakina, O. (2011). The effect of armed conflict on accumulation of schooling: Results from Tajikstan. Journal of Development Economics, 95, 186 - 200.

Swee, E. L. (2009). On War and Schooling Attainment: The Case of Bosnia and Herzegovina. (HiCN Working Papers 57). Households in Conflict Network.

United Nations High Commissioner for Refugees (UNHCR). (2015). UNHCR Statistical Online Population Database. Retrieved September 1, 2015, from $<$ www.unhcr.org/statistics/populationdatabase $>$.

United Nations High Commisioner for Refugees (UNHCR). (2016). Global Trends: Forced Displacement in 2015. Geneva: UNHCR.

Verwimp, P., \& Van Bavel, J. (2013). Schooling, Violent Conflict and Gender in Burundi. (CEB Working Paper 43). Centre Emile Bernheim.

World Bank. (2011). Afghanistan - Research study on IDPs in urban settings.

Washington D. C.: World Bank. 


\section{Appendix}

Table A4.1: Sample, by province

\begin{tabular}{|c|c|c|c|}
\hline \multicolumn{4}{|c|}{ Internally Displaced } \\
\hline Province & No & Yes & Total \\
\hline \multirow[t]{2}{*}{ Kabul } & 32 & 21 & 53 \\
\hline & $5.24 \%$ & $5.13 \%$ & $5.20 \%$ \\
\hline \multirow[t]{2}{*}{ Parwan } & 10 & 12 & 22 \\
\hline & $1.64 \%$ & $2.93 \%$ & $2.16 \%$ \\
\hline \multirow[t]{2}{*}{ Bamyan } & 3 & 4 & 7 \\
\hline & $0.49 \%$ & $0.98 \%$ & $0.69 \%$ \\
\hline \multirow[t]{2}{*}{ Laghman } & 56 & 5 & 61 \\
\hline & $9.17 \%$ & $1.22 \%$ & $5.98 \%$ \\
\hline \multirow[t]{2}{*}{ Nangarhar } & 252 & 69 & 321 \\
\hline & $41.24 \%$ & $16.87 \%$ & $31.47 \%$ \\
\hline \multirow[t]{2}{*}{ Balkh } & 30 & 4 & 34 \\
\hline & $4.91 \%$ & $0.98 \%$ & $3.33 \%$ \\
\hline \multirow[t]{2}{*}{ Faryab } & 22 & 52 & 74 \\
\hline & $3.60 \%$ & $12.71 \%$ & $7.25 \%$ \\
\hline \multirow[t]{2}{*}{ Jawzjan } & 32 & 9 & 41 \\
\hline & $5.24 \%$ & $2.20 \%$ & $4.02 \%$ \\
\hline \multirow[t]{2}{*}{ Sari Pul } & 11 & 1 & 12 \\
\hline & $1.80 \%$ & $0.24 \%$ & $1.18 \%$ \\
\hline \multirow[t]{2}{*}{ Kunduz } & 15 & 10 & 25 \\
\hline & $2.45 \%$ & $2.44 \%$ & $2.45 \%$ \\
\hline \multirow[t]{2}{*}{ Takhar } & 10 & 57 & 57 \\
\hline & $1.64 \%$ & $11.49 \%$ & $5.59 \%$ \\
\hline \multirow[t]{2}{*}{ Helmand } & 25 & 70 & 95 \\
\hline & $4.09 \%$ & $17.11 \%$ & $9.31 \%$ \\
\hline \multirow[t]{2}{*}{ Kandahar } & 30 & 42 & 72 \\
\hline & $4.91 \%$ & $10.27 \%$ & $7.06 \%$ \\
\hline \multirow[t]{2}{*}{ Paktya } & 29 & 3 & 32 \\
\hline & $4.75 \%$ & $0.73 \%$ & $3.14 \%$ \\
\hline \multirow[t]{2}{*}{ Herat } & 54 & 60 & 114 \\
\hline & $8.84 \%$ & $14.67 \%$ & $11.18 \%$ \\
\hline \multirow[t]{2}{*}{ Total } & 611 & 409 & 1,020 \\
\hline & $100 \%$ & $100 \%$ & $100 \%$ \\
\hline
\end{tabular}


Chapter 4

Table A4.2: Relative risk ratio of school attendance (full model)

\begin{tabular}{|c|c|c|c|c|c|c|}
\hline \multirow[t]{2}{*}{ Base: None } & \multicolumn{3}{|c|}{ All School-Aged Children } & \multicolumn{3}{|c|}{ Only School-Aged Boys } \\
\hline & [1] & {$[2]$} & [3] & [1] & {$[2]$} & [3] \\
\hline \multirow[t]{2}{*}{ Int. Displaced } & $0.4937 * * *$ & $0.4838 * * *$ & 0.7608 & $0.6013 * * *$ & $0.6008 * * *$ & 0.8363 \\
\hline & $(0.0731)$ & $(0.0820)$ & $(0.1526)$ & $(0.1070)$ & $(0.1177)$ & $(0.1866)$ \\
\hline \multirow{2}{*}{$\begin{array}{l}\text { Age of } \\
\text { Respondent }\end{array}$} & & $1.0240 * * *$ & $1.0175^{* * *}$ & & 1.0125 & 1.0102 \\
\hline & & $(0.0064)$ & $(0.0066)$ & & $(0.0079)$ & $(0.0081)$ \\
\hline \multirow{2}{*}{$\begin{array}{l}\text { No Formal } \\
\text { Education }\end{array}$} & & $0.2168^{* * *}$ & $0.2515^{* * *}$ & & $0.3199 * * *$ & $0.3544 * * *$ \\
\hline & & $(0.0551)$ & $(0.0702)$ & & $(0.0908)$ & $(0.1084)$ \\
\hline \multirow[t]{2}{*}{ Married } & & 0.9172 & 0.9767 & & 0.8518 & 0.8970 \\
\hline & & $(0.2236)$ & $(0.2449)$ & & $(0.2349)$ & $(0.2546)$ \\
\hline \multirow{2}{*}{$\begin{array}{l}\text { Number of } \\
\text { Children }\end{array}$} & & $1.4467 * * *$ & $1.4191 * * *$ & & $1.4165^{* * *}$ & $1.3748 * * *$ \\
\hline & & $(0.0663)$ & $(0.0686)$ & & $(0.0683)$ & $(0.0676)$ \\
\hline \multirow[t]{2}{*}{ Disabled } & & 1.0609 & 1.0261 & & 1.0117 & 0.8844 \\
\hline & & $(0.2187)$ & $(0.2245)$ & & $(0.2388)$ & $(0.2147)$ \\
\hline \multirow{2}{*}{$\begin{array}{l}\text { Log of HH } \\
\text { Income }\end{array}$} & & 0.9642 & 0.8366 & & 1.0154 & 0.8493 \\
\hline & & $(0.1387)$ & $(0.1322)$ & & $(0.1627)$ & $(0.1438)$ \\
\hline \multirow{2}{*}{$\begin{array}{l}\text { Received } \\
\text { Assistance }\end{array}$} & & 1.1178 & 1.0981 & & 1.0328 & 1.1284 \\
\hline & & $(0.1859)$ & $(0.2014)$ & & $(0.1953)$ & $(0.2322)$ \\
\hline \multicolumn{7}{|l|}{ Ethnicity: } \\
\hline \multirow[t]{2}{*}{ Pashtun } & & 1.0047 & $0.5357 *$ & & 1.1322 & $0.4960 *$ \\
\hline & & $(0.2056)$ & $(0.1722)$ & & $(0.2686)$ & $(0.1941)$ \\
\hline \multirow[t]{2}{*}{ Tajik } & & 1.3890 & 0.9251 & & 1.2603 & 0.6801 \\
\hline & & $(0.4503)$ & $(0.3600)$ & & $(0.4706)$ & $(0.3494)$ \\
\hline \multirow[t]{2}{*}{ Hazara } & & $4.9431 * * *$ & $4.7538^{* * *}$ & & 1.3183 & 1.6275 \\
\hline & & $(1.6628)$ & $(1.9833)$ & & $(0.6456)$ & $(0.9697)$ \\
\hline \multirow[t]{2}{*}{ Other } & & Reference & Reference & & Reference & Reference \\
\hline & & (.) & (.) & & (.) & $()$. \\
\hline \multirow[t]{2}{*}{ Rural } & & & $0.4831^{* * *}$ & & & 0.6840 \\
\hline & & & $(0.1279)$ & & & $(0.2208)$ \\
\hline \multicolumn{7}{|l|}{ Province: } \\
\hline Kabul & & & 1.5777 & & & $4.4663^{* *}$ \\
\hline
\end{tabular}




\begin{tabular}{|c|c|c|c|c|c|c|}
\hline & & & $(0.8360)$ & & & $(2.9700)$ \\
\hline \multirow[t]{2}{*}{ Parwan } & & & 0.4531 & & & 1.3420 \\
\hline & & & $(0.3537)$ & & & (1.0804) \\
\hline \multirow[t]{2}{*}{ Bamyan } & & & $1 \mathrm{E}+07 * * *$ & & & $2 \mathrm{E}+07 * * *$ \\
\hline & & & $(9 \mathrm{E}+06)$ & & & $(2 \mathrm{E}+07)$ \\
\hline \multirow[t]{2}{*}{ Laghman } & & & 1.9940 & & & $4.9130^{* *}$ \\
\hline & & & (1.0905) & & & $(3.5149)$ \\
\hline \multirow[t]{2}{*}{ Nangarhar } & & & $2.8862 * *$ & & & $4.1197^{* *}$ \\
\hline & & & $(1.2621)$ & & & $(2.5119)$ \\
\hline \multirow[t]{2}{*}{ Balkh } & & & 0.7272 & & & 0.5546 \\
\hline & & & $(0.3392)$ & & & $(0.4542)$ \\
\hline \multirow[t]{2}{*}{ Faryab } & & & 1.3677 & & & 0.2737 \\
\hline & & & $(0.5445)$ & & & $(0.2323)$ \\
\hline \multirow[t]{2}{*}{ Jawzjan } & & & $2.5269 *$ & & & $6.9921 * * *$ \\
\hline & & & $(1.3850)$ & & & $(4.1786)$ \\
\hline \multirow[t]{2}{*}{ Sari Pul } & & & $5.0302 *$ & & & 3.6228 \\
\hline & & & $(4.6006)$ & & & $(3.8298)$ \\
\hline \multirow[t]{2}{*}{ Kunduz } & & & 2.2397 & & & $5.3083^{* *}$ \\
\hline & & & $(1.3064)$ & & & $(3.5555)$ \\
\hline \multirow[t]{2}{*}{ Takhar } & & & $0.2186^{* * *}$ & & & 1.1201 \\
\hline & & & $(0.1241)$ & & & $(0.6184)$ \\
\hline \multirow[t]{2}{*}{ Helmand } & & & $2.6690 * *$ & & & $6.6882 * * *$ \\
\hline & & & $(1.2676)$ & & & $(4.0804)$ \\
\hline \multirow[t]{2}{*}{ Kandahar } & & & 0.8271 & & & $3.3102 *$ \\
\hline & & & $(0.4561)$ & & & $(2.0605)$ \\
\hline \multirow[t]{2}{*}{ Paktya } & & & 1.2210 & & & $5.7361 * *$ \\
\hline & & & $(0.8061)$ & & & $(4.2458)$ \\
\hline \multirow[t]{2}{*}{ Herat } & & & Reference & & & Reference \\
\hline & & & (.) & & & (.) \\
\hline Adj. $\mathrm{R}^{2}$ & 0.0102 & 0.1158 & 0.1742 & 0.0102 & 0.1158 & 0.1742 \\
\hline $\mathrm{N}$ & 1020 & 1020 & 1020 & 1020 & 1020 & 1020 \\
\hline
\end{tabular}

Significance Levels: ${ }^{*} \mathrm{p}<0.10,{ }^{* *} \mathrm{p}<0.05,{ }^{* * *} \mathrm{p}<0.01$. 
Chapter 4

Table A4.3: Relative risk ratio of food insecurity (full model)

\begin{tabular}{|c|c|c|c|c|c|c|}
\hline \multirow[t]{2}{*}{ Base: Never } & \multicolumn{3}{|c|}{ Rarely (1-2 times/month) } & \multicolumn{3}{|c|}{ Often ( $>3$ times/month) } \\
\hline & {$[1]$} & {$[2]$} & {$[3]$} & {$[1]$} & {$[2]$} & {$[3]$} \\
\hline Int. Displaced & $\begin{array}{c}1.9005 * * * \\
(0.3522)\end{array}$ & $\begin{array}{c}1.9340 * * * \\
(0.3836)\end{array}$ & $\begin{array}{c}2.0554 * * * \\
(0.4628)\end{array}$ & $\begin{array}{c}2.0895 * * * \\
(0.3964)\end{array}$ & $\begin{array}{c}2.1239 * * * \\
(0.4434)\end{array}$ & $\begin{array}{c}2.0358 * * * \\
(0.4717)\end{array}$ \\
\hline $\begin{array}{l}\text { Age of } \\
\text { Respondent }\end{array}$ & & $\begin{array}{c}1.0193^{* * *} \\
(0.0071)\end{array}$ & $\begin{array}{c}1.0197 * * * \\
(0.0074)\end{array}$ & & $\begin{array}{c}1.0238^{* * *} \\
(0.0074)\end{array}$ & $\begin{array}{c}1.0250 * * * \\
(0.0076)\end{array}$ \\
\hline $\begin{array}{l}\text { No Formal } \\
\text { Education }\end{array}$ & & $\begin{array}{c}0.7521 \\
(0.1792)\end{array}$ & $\begin{array}{c}0.7701 \\
(0.1911)\end{array}$ & & $\begin{array}{c}1.1937 \\
(0.3143)\end{array}$ & $\begin{array}{c}1.2816 \\
(0.3527)\end{array}$ \\
\hline Married & & $\begin{array}{c}1.2187 \\
(0.2956)\end{array}$ & $\begin{array}{c}1.2448 \\
(0.3118)\end{array}$ & & $\begin{array}{c}0.7504 \\
(0.1842)\end{array}$ & $\begin{array}{c}0.7144 \\
(0.1814)\end{array}$ \\
\hline $\begin{array}{l}\text { Number of } \\
\text { Children }\end{array}$ & & $\begin{array}{c}0.9819 \\
(0.0319)\end{array}$ & $\begin{array}{c}0.9845 \\
(0.0348)\end{array}$ & & $\begin{array}{l}0.9322 * \\
(0.0342)\end{array}$ & $\begin{array}{l}0.9229 * * \\
(0.0366)\end{array}$ \\
\hline Disabled & & $\begin{array}{c}0.9700 \\
(0.2178)\end{array}$ & $\begin{array}{c}0.9799 \\
(0.2219)\end{array}$ & & $\begin{array}{c}0.9221 \\
(0.2173)\end{array}$ & $\begin{array}{c}0.8485 \\
(0.2051)\end{array}$ \\
\hline $\begin{array}{l}\text { Log of HH } \\
\text { Income }\end{array}$ & & $\begin{array}{c}0.4445 * * * \\
(0.0836)\end{array}$ & $\begin{array}{c}0.4556^{* * *} \\
(0.0908)\end{array}$ & & $\begin{array}{c}0.2740 * * * \\
(0.0573)\end{array}$ & $\begin{array}{c}0.2673 * * * \\
(0.0582)\end{array}$ \\
\hline $\begin{array}{l}\text { Received } \\
\text { Assistance }\end{array}$ & & $\begin{array}{r}0.7544 \\
(0.1352)\end{array}$ & $\begin{array}{l}0.6970 * \\
(0.1353)\end{array}$ & & $\begin{array}{l}0.7084 * \\
(0.1343)\end{array}$ & $\begin{array}{c}0.5804 * * * \\
(0.1181)\end{array}$ \\
\hline $\begin{array}{l}\text { Ethnicity: } \\
\text { Pashtun }\end{array}$ & & $\begin{array}{c}1.1207 \\
(0.2626)\end{array}$ & $\begin{array}{c}1.0771 \\
(0.3916)\end{array}$ & & $\begin{array}{c}1.4792 \\
(0.3700)\end{array}$ & $\begin{array}{c}1.0746 \\
(0.4313)\end{array}$ \\
\hline Tajik & & $\begin{array}{c}1.1362 \\
(0.4018)\end{array}$ & $\begin{array}{c}1.0099 \\
(0.4277)\end{array}$ & & $\begin{array}{c}1.1038 \\
(0.4092)\end{array}$ & $\begin{array}{c}0.8698 \\
(0.4055)\end{array}$ \\
\hline Hazara & & $\begin{array}{c}1.4497 \\
(0.5646)\end{array}$ & $\begin{array}{c}1.6255 \\
(0.7403)\end{array}$ & & $\begin{array}{c}1.0094 \\
(0.4244)\end{array}$ & $\begin{array}{c}0.8475 \\
(0.4296)\end{array}$ \\
\hline Other & & $\begin{array}{c}\text { Reference } \\
\text { (.) }\end{array}$ & $\begin{array}{c}\text { Reference } \\
\text { (.) }\end{array}$ & & $\begin{array}{c}\text { Reference } \\
\text { (.) }\end{array}$ & $\begin{array}{c}\text { Reference } \\
\text { (.) }\end{array}$ \\
\hline Rural & & & $\begin{array}{c}1.0559 \\
(0.2915)\end{array}$ & & & $\begin{array}{l}1.8748 * * \\
(0.5398)\end{array}$ \\
\hline $\begin{array}{c}\text { Province: } \\
\text { Kabul }\end{array}$ & & & 0.8981 & & & 0.4612 \\
\hline
\end{tabular}




\begin{tabular}{|c|c|c|c|c|c|c|}
\hline & & & $(0.4373)$ & & & $(0.2452)$ \\
\hline \multirow[t]{2}{*}{ Parwan } & & & 0.7343 & & & 0.3162 \\
\hline & & & $(0.4961)$ & & & $(0.2537)$ \\
\hline \multirow[t]{2}{*}{ Bamyan } & & & 1.3172 & & & 1.4772 \\
\hline & & & $(1.4272)$ & & & $(1.6537)$ \\
\hline \multirow[t]{2}{*}{ Laghman } & & & 1.3631 & & & 0.5933 \\
\hline & & & $(0.7768)$ & & & $(0.3722)$ \\
\hline \multirow[t]{2}{*}{ Nangarhar } & & & 1.4112 & & & 1.6506 \\
\hline & & & $(0.6519)$ & & & $(0.7807)$ \\
\hline \multirow[t]{2}{*}{ Balkh } & & & 0.9220 & & & 0.5201 \\
\hline & & & $(0.4605)$ & & & $(0.3023)$ \\
\hline \multirow[t]{2}{*}{ Faryab } & & & 1.7592 & & & 0.6760 \\
\hline & & & $(0.9194)$ & & & $(0.3685)$ \\
\hline \multirow[t]{2}{*}{ Jawzjan } & & & 0.6176 & & & $0.2206^{* * *}$ \\
\hline & & & $(0.3067)$ & & & $(0.1248)$ \\
\hline \multirow[t]{2}{*}{ Sari Pul } & & & 0.5424 & & & $0.2451 *$ \\
\hline & & & $(0.4640)$ & & & $(0.2085)$ \\
\hline \multirow[t]{2}{*}{ Kunduz } & & & 0.6538 & & & 0.7461 \\
\hline & & & $(0.4426)$ & & & $(0.5391)$ \\
\hline \multirow[t]{2}{*}{ Takhar } & & & 2.3074 & & & 1.2984 \\
\hline & & & $(1.4056)$ & & & $(0.8226)$ \\
\hline \multirow[t]{2}{*}{ Helmand } & & & 0.9170 & & & 1.3509 \\
\hline & & & $(0.4750)$ & & & $(0.7123)$ \\
\hline \multirow[t]{2}{*}{ Kandahar } & & & 0.5688 & & & 0.7857 \\
\hline & & & $(0.3016)$ & & & $(0.4143)$ \\
\hline \multirow[t]{2}{*}{ Paktya } & & & 2.1580 & & & 1.3834 \\
\hline & & & $(1.4179)$ & & & $(0.9172)$ \\
\hline \multirow[t]{2}{*}{ Herat } & & & Reference & & & Reference \\
\hline & & & (.) & & & (.) \\
\hline Adj. $R^{2}$ & 0.0080 & 0.0533 & 0.0823 & 0.0080 & 0.0533 & 0.0823 \\
\hline $\mathrm{N}$ & 1020 & 1020 & 1020 & 1020 & 1020 & 1020 \\
\hline
\end{tabular}

Significance Levels: ${ }^{*} \mathrm{p}<0.10,{ }^{* *} \mathrm{p}<0.05,{ }^{* * *} \mathrm{p}<0.01$. 
Chapter 4

Table A4.4: Marginal effect of dietary diversity (full model)

\begin{tabular}{|c|c|c|c|c|c|c|}
\hline & \multicolumn{3}{|c|}{ Probability of Eating Meat } & \multicolumn{3}{|c|}{ No. of Times Eating Meat (if $>0$ ) } \\
\hline & {$[1]$} & {$[2]$} & {$[3]$} & {$[1]$} & [2] & {$[3]$} \\
\hline Int. Displaced & $\begin{array}{c}-0.1186^{* * *} \\
(0.0270)\end{array}$ & $\begin{array}{c}-0.1161^{* * *} \\
(0.0286)\end{array}$ & $\begin{array}{c}-0.1700 * * * \\
(0.0331)\end{array}$ & $\begin{array}{c}-0.2419 * * * \\
(0.0558)\end{array}$ & $\begin{array}{c}-0.2189 * * * \\
(0.0556)\end{array}$ & $\begin{array}{c}-0.2986 * * * \\
(0.0599)\end{array}$ \\
\hline $\begin{array}{l}\text { Age of } \\
\text { Respondent }\end{array}$ & & $\begin{array}{l}-0.0006 \\
(0.0010)\end{array}$ & $\begin{array}{l}-0.0004 \\
(0.0010)\end{array}$ & & $\begin{array}{l}-0.0011 \\
(0.0019)\end{array}$ & $\begin{array}{l}-0.0007 \\
(0.0018)\end{array}$ \\
\hline $\begin{array}{l}\text { No Formal } \\
\text { Education }\end{array}$ & & $\begin{array}{l}-0.0518 \\
(0.0374)\end{array}$ & $\begin{array}{l}-0.0406 \\
(0.0385)\end{array}$ & & $\begin{array}{l}-0.1023 \\
(0.0761)\end{array}$ & $\begin{array}{l}-0.0745 \\
(0.0723)\end{array}$ \\
\hline Married & & $\begin{array}{c}0.0573 \\
(0.0395)\end{array}$ & $\begin{array}{c}0.0845^{* *} \\
(0.0403)\end{array}$ & & $\begin{array}{c}0.1063 \\
(0.0715)\end{array}$ & $\begin{array}{c}0.1442 * * \\
(0.0664)\end{array}$ \\
\hline $\begin{array}{l}\text { Number of } \\
\text { Children }\end{array}$ & & $\begin{array}{c}0.0219 * * * \\
(0.0047)\end{array}$ & $\begin{array}{c}0.0141^{* * *} \\
(0.0053)\end{array}$ & & $\begin{array}{c}0.0420^{* * *} \\
(0.0087)\end{array}$ & $\begin{array}{c}0.0253 * * * \\
(0.0093)\end{array}$ \\
\hline Disabled & & $\begin{array}{l}-0.0675^{*} \\
(0.0371)\end{array}$ & $\begin{array}{l}-0.0670^{*} \\
(0.0381)\end{array}$ & & $\begin{array}{c}-0.1253^{*} \\
(0.0660)\end{array}$ & $\begin{array}{l}-0.1164 * \\
(0.0636)\end{array}$ \\
\hline $\begin{array}{l}\text { Log of HH } \\
\text { Income }\end{array}$ & & $\begin{array}{c}0.2340 * * * \\
(0.0397)\end{array}$ & $\begin{array}{c}0.2196 * * * \\
(0.0403)\end{array}$ & & $\begin{array}{c}0.4482 * * * \\
(0.0683)\end{array}$ & $\begin{array}{c}0.3933 * * * \\
(0.0664)\end{array}$ \\
\hline $\begin{array}{l}\text { Received } \\
\text { Assistance }\end{array}$ & & $\begin{array}{c}0.0136 \\
(0.0279)\end{array}$ & $\begin{array}{l}0.0570 * * \\
(0.0288)\end{array}$ & & $\begin{array}{c}0.0260 \\
(0.0534)\end{array}$ & $\begin{array}{l}0.1028 * * \\
(0.0523)\end{array}$ \\
\hline $\begin{array}{l}\text { Ethnicity: } \\
\text { Pashtun }\end{array}$ & & $\begin{array}{c}0.1328 * * * \\
(0.0348)\end{array}$ & $\begin{array}{l}-0.0601 \\
(0.0475)\end{array}$ & & $\begin{array}{c}0.2486^{* * *} \\
(0.0663)\end{array}$ & $\begin{array}{l}-0.1093 \\
(0.0879)\end{array}$ \\
\hline Tajik & & $\begin{array}{c}0.0688 \\
(0.0506)\end{array}$ & $\begin{array}{c}0.0055 \\
(0.0579)\end{array}$ & & $\begin{array}{c}0.1389 \\
(0.1079)\end{array}$ & $\begin{array}{c}0.0099 \\
(0.1045)\end{array}$ \\
\hline Hazara & & $\begin{array}{l}-0.0632 \\
(0.0606)\end{array}$ & $\begin{array}{l}-0.1021 \\
(0.0728)\end{array}$ & & $\begin{array}{l}-0.1159 \\
(0.1067)\end{array}$ & $\begin{array}{l}-0.1707 \\
(0.1145)\end{array}$ \\
\hline Other & & $\begin{array}{c}\text { Reference } \\
\text { (.) }\end{array}$ & $\begin{array}{c}\text { Reference } \\
\text { (.) }\end{array}$ & & $\begin{array}{c}\text { Reference } \\
\text { (.) }\end{array}$ & $\begin{array}{c}\text { Reference } \\
\text { (.) }\end{array}$ \\
\hline Rural & & & $\begin{array}{c}-0.2062 * * * \\
(0.0402)\end{array}$ & & & $\begin{array}{c}-0.4217 * * * \\
(0.0974)\end{array}$ \\
\hline Province: & & & & & & \\
\hline Kabul & & & $\begin{array}{c}0.1498 * * \\
(0.0714)\end{array}$ & & & $\begin{array}{l}0.3112 * \\
(0.1759)\end{array}$ \\
\hline
\end{tabular}




\begin{tabular}{|c|c|c|c|c|c|c|}
\hline \multirow[t]{2}{*}{ Parwan } & & & 0.0977 & & & 0.1927 \\
\hline & & & $(0.1025)$ & & & $(0.2247)$ \\
\hline \multirow[t]{2}{*}{ Bamyan } & & & -0.1543 & & & -0.2473 \\
\hline & & & $(0.2408)$ & & & $(0.3519)$ \\
\hline \multirow[t]{2}{*}{ Laghman } & & & -0.1095 & & & -0.1820 \\
\hline & & & $(0.0814)$ & & & $(0.1267)$ \\
\hline \multirow[t]{2}{*}{ Nangarhar } & & & 0.0620 & & & 0.1136 \\
\hline & & & $(0.0658)$ & & & $(0.1238)$ \\
\hline \multirow[t]{2}{*}{ Balkh } & & & -0.1257 & & & -0.2059 \\
\hline & & & $(0.0941)$ & & & $(0.1426)$ \\
\hline \multirow[t]{2}{*}{ Faryab } & & & $0.2442 * * *$ & & & $0.5695 * * *$ \\
\hline & & & $(0.0505)$ & & & $(0.1602)$ \\
\hline \multirow[t]{2}{*}{ Jawzjan } & & & 0.1122 & & & 0.2239 \\
\hline & & & $(0.0796)$ & & & $(0.1791)$ \\
\hline \multirow[t]{2}{*}{ Sari Pul } & & & -0.0399 & & & -0.0692 \\
\hline & & & $(0.1327)$ & & & $(0.2228)$ \\
\hline \multirow[t]{2}{*}{ Kunduz } & & & -0.1231 & & & -0.2016 \\
\hline & & & $(0.1097)$ & & & $(0.1660)$ \\
\hline \multirow[t]{2}{*}{ Takhar } & & & $-0.1332^{*}$ & & & $-0.2181^{*}$ \\
\hline & & & $(0.0794)$ & & & $(0.1200)$ \\
\hline \multirow[t]{2}{*}{ Helmand } & & & $0.2491^{* * *}$ & & & $0.5763 * * *$ \\
\hline & & & $(0.0570)$ & & & $(0.1795)$ \\
\hline \multirow[t]{2}{*}{ Kandahar } & & & $0.4274 * * *$ & & & $1.5189 * * *$ \\
\hline & & & $(0.0338)$ & & & $(0.3039)$ \\
\hline \multirow[t]{2}{*}{ Paktya } & & & 0.1368 & & & 0.2818 \\
\hline & & & $(0.0862)$ & & & $(0.2075)$ \\
\hline \multirow[t]{2}{*}{ Herat } & & & Reference & & & Reference \\
\hline & & & $()$. & & & $()$. \\
\hline Adj. $\mathrm{R}^{2}$ & 0.0058 & 0.0518 & 0.0900 & 0.0058 & 0.0518 & 0.0900 \\
\hline $\mathrm{N}$ & 1020 & 1020 & 1020 & 1020 & 1020 & 1020 \\
\hline
\end{tabular}

Significance Levels: ${ }^{*} \mathrm{p}<0.10,{ }^{* *} \mathrm{p}<0.05,{ }^{* * *} \mathrm{p}<0.01$. 



\section{Chapter 5}

\section{The Occupational Choice of Forced Migrants upon Return ${ }^{16}$}

\subsection{Introduction}

The topic of forced migration is currently receiving a considerable amount of attention both within high level policy circles and across popular media. This heightened interest is mostly due to the fact that the number of people in exile, 65.3 million, is higher than any time since modern recordkeeping began in earnest (UNHCR, 2016). While it is difficult to estimate just how many of today's forced migrant population ultimately will be integrated into their host societies, an important consideration over the medium- and long-term is the eventual return, either voluntarily or not, of many back to their countries of origin. Indeed, just as the influx of migrants from elsewhere might have significant development-related implications for a local community, so to can the sudden influx of returnees who may have spent years abroad in very particular circumstances.

Only recently has return migration begun to gain interest among academic scholars and policymakers as evidence mounts that the knowledge, skills and savings acquired abroad and transferred upon return have the potential to contribute to development in countries experiencing significant return flows. For this potential to be realized, however, the manner in which returnees reintegrate into their communities, including into the labor market, may be essential. In this regard, certain case studies on record have found that return migrants are more likely than non-migrants to be self-employed rather than employed as wage labor (Piracha \& Vadean, 2010; Wahba \& Zenou, 2012). Yet such an observation is ultimately ambiguous without a qualified understanding of the greater context under study, including importantly the underlying causes of migration in the first place. The majority of studies, in fact, looking at the occupational choice of return migrants

\footnotetext{
${ }^{16}$ This chapter is based on an article currently under peer-review, co-authored with Katrin Marchand and titled "Getting Back to Work: The Occupational Choice of Forced Migrants upon Return to Afghanistan".
} 
focus mainly on countries characterized by voluntary labor migration. Only a few offer insight into the livelihood activities of returned refugees (see, e.g., Van Houte \& Koning, 2008; Mesic \& Bagic, 2011; Fransen \& Kuschminder, 2012; Gladwell \& Elywn, 2012; ILO, 2013), and none to the best of our knowledge taking a quantitative approach.

With this in mind, this paper investigates the occupational choice of return migrants in Afghanistan, whose initial migration was due to conflict and general insecurity. We are motivated by the fact that the reintegration of returnees in a (post-) conflict setting such as Afghanistan greatly depends on their ability to access sustainable income-generating activities as a basis of their livelihood. Our analytical approach is twofold: to first compare non-migrants and return migrants in regards to what influences their respective occupational choices; and second, to investigate the influence of the returnees' migration and return experience on their occupational choice. Because we are interested in the labor market reintegration of returnees who were forced to migrate, we only take into consideration those returnees who originally migrated because of political or security concerns, or because of an environmental disaster. With these restrictions, the sample ultimately covers 2,304 individuals, of which 504 are returnees.

Our results indicate that return migrants are less likely to be wage employed in comparison to non-migrants. Differences in occupational choice seem to arise from dissimilarities in socio-economic status including educational attainment, household income and the strength of social networks. As for the influence of the migration and return experience on occupational choice, a few key factors are found to be of consequence. First and somewhat expected, being employed prior to migrating helps raise the likelihood of being wage employed upon return. Less expected, however, given the context of forced displacement, the more years spent abroad the greater the odds of being self-employed in business or wage employed, possibly indicating some sort of skill acquisition. Moreover, the amount of savings brought back upon return is positively associated with becoming self-employed in agriculture or herding, while the opposite is true if the individual received assistance upon return or has intentions to re-migrate.

The remainder of this chapter is structured as follows. The next section provides a brief review of the relevant literature concerning return migration and the dynamics 
related to occupational choice upon return. This is followed by a more detailed account of our methodology including the empirical approach and sample. We finally present the results and summarize our findings, and conclude with a brief policy discussion about the potential ways to assist returnees in Afghanistan in their labor market reintegration.

\subsection{Literature Review}

In a (post-) conflict setting still fraught with lingering uncertainty about the future, the sustainability of return and reintegration is top priority, yet often a challenging process (Bascom, 2005). Many factors contribute to a successful return and reintegration including a welcoming community, security, access to basic infrastructure and services, and the chance to make a decent living. A robust local labor market providing job opportunities and livelihood possibilities should therefore greatly influence whether or not a returnee chooses to settle permanently at origin (Black \& Gent, 2006). Unfortunately in the case of Afghanistan, well-paid wage labor is broadly insufficient especially in rural areas of high return (CSO, 2014). As such, self-employment may be one of the few income-generating activities available to support oneself and family.

While self-employment in certain contexts may intrinsically be subsistence-based it is helpful to consider such an activity in relation to entrepreneurship, which more often than not is associated with positive changes such as job and wealth creation, innovation and related welfare effects (Acs, 2006; Desai, 2009; Naudé, 2010). Desai (2009), for example, argues that entrepreneurship creates bottom-up activities addressing immediate and short-term problems. Naudé (2010), on the other hand, believes entrepreneurs drive the structural transformation of an economy away from agriculture and towards manufacturing and services. Beyond these macro-level effects though, small businesses may also simply be a viable survival strategy when institutional support mechanisms are lacking (Ciarli et al., 2010). In this respect, it is necessary to make the distinction between opportunity and necessity entrepreneurship. Whereas opportunity entrepreneurs are thought to seize unique opportunities in the market, necessity entrepreneurs engage in entrepreneurial activities because it is the best or only option available (Reynolds et al., 2001). While entrepreneurship based on opportunity may be preferred, it is still important to take into account the activities of necessity entrepreneurs given 
their enterprises provide at a minimum one livelihood and have the potential to contribute to local development (Ciarli et al., 2010).

When it comes to the potential success of any entrepreneurial venture, Burt (2000) argues that three primary types of capital are essential: financial, human and social. Financial capital principally consists of personal savings as well as private and public loans either from friends and family, a financial institution or the government. Human capital describes natural characteristics like intelligence and health, but also skills and abilities acquired mainly through education and work experience. And social capital embodies an individual's relationships to others and the network on which one can rely. With all, a return migrant is believed to have a distinct advantage in comparison to his/her non-migrant counterpart (Black et al., 2003). Beyond the potentially innate differences regarding risk aversion and the like, returnees often had sent or come back with substantial savings accumulated while abroad with the explicit objective of consuming and/or investing once back (OECD, 2008). Moreover, returnees might arrive with additionally acquired education or skills useful to local production (Cassarino, 2004). Lastly, in many cases spending time abroad exposes one to a diverse set of social networks providing a greater number of links and thus opportunities upon return, even if migrating in the first place may have led to an initial loss in contact with those left behind (Klagge et al., 2007).

With these theoretical underpinnings at hand, a growing number of empirical studies have made an effort to identify not only the occupational choice of returnees but the specific factors leading to small business establishment. The most common finding relates to financial capital, and more specifically the role of savings accumulated abroad in the launch of a small business upon return. For instance, both Arif and Irfan (1997) and Piracha and Vadean (2010) find strong indication that return migrants are more likely to be self-employed in business in comparison to non-migrants precisely because they had the opportunity to gather start-up capital abroad. Focusing exclusively on return migrants, Ilahi (1999), Dustmann and Kirchkamp (2002) and Mesnard (2004) arrive at similar conclusions showing return migrants are particularly prone to invest savings from abroad in business ventures back home, suggesting temporary migration may at times be employed as a strategy to overcome credit constraints faced in the country of origin. 
Beyond the role of savings, there is also ample evidence that points to the importance of human capital in small business creation by returnees. The same study by Dustmann and Kirchkamp (2002) finds evidence of education as a driving factor in self-employment, as those with a higher level attained have a greater probability of opening a business compared to being wage employed. Borodak and Piracha (2011) confirm such a finding when it comes to returning Moldovans, yet explain that those at a lower skill level are unable to afford being without a formal source of income leading to the greater likelihood of wage employment. Conversely however, Ilahi (1999) and McCormick and Wahba (2001) show that returnees with higher levels of education are more likely to be wage employed rather than self-employed in the case of Pakistan and Egypt, respectively. Still, additional evidence in the latter case suggests that the length of employment while abroad also positively influences the odds of becoming self-employed upon return, an outcome corroborated elsewhere (McCormick \& Wahba, 2001; Black \& Castaldo, 2009; Wahba \& Zenou, 2012). Therefore it appears, as Tani and Mahuteau (2008) show in their study of returnees in North Africa, that the practical experiences and skills gained abroad play a crucial role in determining selfemployment, while formal education is more likely to lead to wage employment even if it also decreases the chance of unemployment.

Finally, when it comes to social capital, it is clear that personal networks play a significant role in the reintegration of return migrants in the home country (Omata, 2012). The role networks play in the occupational choice of returnees is, on the other hand, empirically unclear. Black and Castaldo (2009), for instance, find that the strength of personal linkages, measured by membership in an association in the host country and visits home, does have a positive effect on business start-ups of return migrants in both Ghana and Côte d'Ivoire. Conversely, Piracha and Vadean (2010) show in the case of Albania no evidence of social capital, proxied by the number of friends one has, having any impact on the occupational choice of return migrants despite there being a significant effect for non-migrants. Going one step further, Wahba and Zenou (2012) model the potential trade-off between the financial and human capital accumulated while abroad against the social capital lost due to moving in the first place. In the context of Egypt, they provide evidence that gains in both financial and human capital play a significant role in the choice of self-employment upon return, whereas a loss in social capital has no impact on returnees to become entrepreneurs even if it does for non-migrants. 
Although at times differing, overall these studies indicate that the migration experience greatly influences labor market outcomes of return migrants once back in the country of origin. Still, these experiences are not uniform as some individuals are inherently presented with greater opportunities abroad and therefore greater job prospects upon return (Arif \& Irhan, 1997; Gubert \& Nordmann, 2011; Kilic et al., 2007). In a study of returnees in seven capital cities in Western Africa for example, de Vreyer et al. (2010) show that there are significant differences in the uptake of an entrepreneurial activity upon return depending on the country of migration. In particular they find those who returned from OECD countries in comparison to non-OECD countries are more likely to be entrepreneurs due to the better chances to accumulate financial and human capital at those destinations. Additionally, differences in the environment to which the migrant returns also play an important role.

In the case of Afghanistan, the many years of conflict have had a severe impact on the formal labor market and the job opportunities available. Indeed the latest round of the National Risk and Vulnerability Assessment (NRVA) from 2011/12 cites a quarter of the population not gainfully employed (CSO, 2014). And this figure may very well be underestimating the problem as the International Labour Organization (ILO) reports an underemployment rate of 48.2 percent (ILO, 2012). Therefore, given the general challenges present in Afghanistan for not only returnees but the population at large, the occupational choice of self-employment, even if out of necessity, may simply be the only if not best strategy towards sustainable return.

\subsection{Methodology}

\section{Empirical Approach}

As indicated prior, our objective is twofold: to compare non-migrants and return migrants in regards to what influences their respective occupational choices; and second, to investigate the influence of the returnees' migration and return experience on their occupational choice. In both cases we employ a multinomial logit model to estimate the propensity that an individual chooses one occupation compared to a base alternative. The formal expression of our model is: 


$$
\operatorname{Pr}\left(y_{i}=j\right)=\frac{e^{\beta_{j} x_{i}}}{\sum_{j=1}^{K} e^{\beta_{j} x_{i}}}
$$

where $y_{i}$ represents the occupational choice $j$ of individual $i, x_{i}$ indicates the vector of individual-specific characteristics influencing occupational choice, and $\beta_{j}$ represents the vector of choice-specific coefficients.

The outcome variable, occupational choice, has four distinct categories: not working, self-employment in business, self-employment in agriculture or herding and wage employment. We utilize not working as a base category which all of the other three categories are compared against. On the right hand side of the equation, the $x_{i}$ vector incorporates a broad range of individual, household and community characteristics, as well as migration- and return-related characteristics when looking exclusively at return migrants.

Prior to estimating the occupational choice model however, we investigate the possibility of selection in our sample. As has been established elsewhere, there is reason to believe both migrants and return migrants may be intrinsically different from non-migrants based on unobservable characteristics. Most of the evidence in this regard pertains to labor migration and the prospect that migrants are inherently more intrepid and thus less risk averse than the non-migrant population, and that return migrants may have picked up informal skills and expertise during their time abroad (Dustmann \& Kirchkamp, 2002; OECD, 2008; OECD, 2010). Yet the migratory trends in Afghanistan have been predominately characterized by involuntary movement due to conflict and insecurity. With this in mind, we restrict our sample to include only those return migrants who originally migrated because of political or security concerns, or because of an environmental disaster. ${ }^{17}$

On the other hand, the motivation for return may also matter. People that are displaced by conflict may only return voluntarily when they believe the overall security situation has improved, and job opportunities now exist (Novak, 2007;

\footnotetext{
${ }^{17}$ Even though we exclude those return migrants who indicated voluntary migration, the percentage of total returnees who voluntarily migrated before filtering is only 25 percent.
} 
Hautaniemi et al., 2013). In this regard, we exclude those individuals who stated that they returned for employment opportunities. ${ }^{18}$ Moreover, we test for selfselection of a return migrant into a particular occupational category following the methods of Borodak and Piracha (2011). First, we estimate the likelihood of an individual being a return migrant using a probit model, and then introduce the generalized residual from the results into our occupational choice estimation. The statistical insignificance of the residual coefficient within the occupational choice model should indicate the absence of self-selection, suggesting our estimates are unbiased.

\section{Sample}

The sample used for this analysis originates from an Afghanistan household survey collected for the IS Academy 'Migration \& Development: a World in Motion' project. Once excluding individuals outside the working age of $15-65$, females ${ }^{19}$, current migrants as well as return migrants who migrated voluntarily and before 1992, we are left with a total sample of 2,304 respondents of which 504 are return migrants. Table 18 provides the summary statistics of our full sample, as well as when differentiated by migration status. We also report a mean difference test in the final column, which only applies to those variables applicable to both nonmigrants and return migrants.

In comparing non-migrants to return migrants based on our outcome variable of interest, occupational category, we find that returnees are 14 percentage points less likely to be unemployed with the difference being returnees are more likely to be self-employed in business. There is no statistical difference between selfemployment in agriculture or herding or wage employment. As for independent variables of interest, there is a substantial difference in terms of household position

\footnotetext{
${ }^{18}$ The percentage of total returnees who came back for employment opportunities is less than one percent. All others returned either because of improvements to the political or security situation, or for a variety of personal reasons (i.e. wanted to be closer to my family and friends).

${ }^{19}$ Our choice to focus only on male respondents stems from the fact that women's labor force participation in Afghanistan is systematically lower than that of men. The most recent NRVA for 2011/2012 (CSO, 2014) reports a female labor force participation of 19 percent compared to 80 percent for their male counterparts.
} 
and age as nearly all return migrants are the household head in comparison to less than half of non-migrants, and the average difference in age between the two groups is 11 years. Likewise, returnees are much more likely to be married in comparison to non-migrants, as well as have more children. Regarding educational attainment, around half of the entire sample has no formal education and there is nearly no dissimilarity between groups. In terms of socio-economic status, there is no discernable difference between groups based on the log of household income as well as land ownership. Still, return migrants are on average 11 percentage points more likely to have a social network, indicated by involvement in a community organization other than a religious group. Concerning general control variables, there is little difference in district type although return migrants are slightly more prone to be located in semi-rural areas. Return migrants are 12 percentage points more likely to be of Pashtun ethnicity, while non-migrants are more likely to be of Tajik descent. Finally, return migrants are more prone to be located in Nangarhar, while the opposite is true in Herat and Balkh.

In looking at some of the migration-related characteristics for return migrants only, we find just over two-thirds of all returnees migrated to Pakistan while the rest went to Iran. Moreover, the average time abroad is around 12 years and only five percent sent remittances during that period. In terms of the return experience, around half repatriated between the fall of the Najibullah regime in 1992 and the ouster of the Taliban regime in 2001, corresponding to the average of 10 years since return. Nearly three-fourths of returnees cited improvements in the political and/or security situation as the main reason for return, while the rest reported personal reasons (i.e. wanted to be closer to my family and friends). The average amount of savings brought back upon return was around 760 USD with a log of 1.63 , and 29 percent received support upon return in the form of financial assistance by either an international organization or the government. Lastly, only 19 percent of returnees have concrete intentions to re-migrate in the future. 


\begin{tabular}{lllllllll}
\hline \hline \multicolumn{2}{l}{ Full Sample } & & \multicolumn{2}{l}{ Non-Migrants } & \multicolumn{2}{l}{ Return Migrants } & \\
mean & sd & & mean & sd & & mean & sd & t-test \\
\hline
\end{tabular}

\title{
Outcome
}

Occupational Category:

Not working

0.3286

0.4698

0.3589

0.4798

0.2202

0.4148

SE: Business

0.3611

0.4804

0.3344

0.4719

0.4563

0.4986

SE: Agric./herding

0.1098

0.3127

0.1044

0.3059

0.1290

0.3355

Wage employed

0.2005

0.4005

0.2022

0.4018

0.1944

0.3962

Independent Variables

Head of $\mathrm{HH}$

Age

Married

$\begin{array}{llllll}0.5234 & 0.4996 & 0.4133 & 0.4926 & 0.9167 & 0.2767\end{array}$

$\begin{array}{lllllll}32.75 & 14.77 & 30.34 & 14.39 & 41.38 & 12.74\end{array}$

$\begin{array}{llllll}0.5825 & 0.4933 & 0.4906 & 0.5000 & 0.9107 & 0.2854\end{array}$

Number of Children

$$
2.95
$$$$
1.91
$$

2.87

1.91

3.24

1.87

Education Attainment:

No formal

$\begin{array}{lllllll}0.5139 & 0.4999 & 0.5183 & 0.4998 & 0.4980 & 0.5005\end{array}$

Less than secondary

$0.3134 \quad 0.4640$

0.3150

0.4646

$\begin{array}{ll}0.3075 & 0.4619\end{array}$

Secondary or higher

$\begin{array}{ll}0.1567 & 0.3636\end{array}$

0.1544

0.3615

0.1647

0.3713

Other non-traditional

0.0161

0.1257

0.0122

0.1099

0.0298

0.1701

Log of HH Income

3.5721

$\begin{array}{lll}0.6620 & 3.5629\end{array}$

0.6687

3.6051

0.6370

HH Owns Land

0.2253

0.4178

0.2261

0.4184

0.2222

0.4162

Social Network

$\begin{array}{llll}0.7127 & 0.4526 & 0.6889\end{array}$

0.4631

0.7976

0.4022

Ethnicity:

Pashtun

$0.4648 \quad 0.4989$

$0.4245 \quad 0.4944$

0.4372

0.4962

0.5635

0.4964

$0.1107 \quad 0.3138$

0.4494

0.4976

0.3353

0.4726

Other

0.1133

0.3171

$\begin{array}{ll}0.1012 & 0.3019\end{array}$

District Type:

Urban

Semi-rural

Rural

Province:

Kabul

Herat

Balkh

Nangarhar

Kandahar $\begin{array}{lllllll}0.5139 & 0.4999 & 0.5167 & 0.4999 & 0.5040 & 0.5005\end{array}$

$\begin{array}{lllllll}0.2348 & 0.4240 & 0.2244 & 0.4173 & 0.2718 & 0.4453\end{array}$

$\begin{array}{lllllll}0.2513 & 0.4339 & 0.2589 & 0.4381 & 0.2242 & 0.4175\end{array}$
0.1828

0.3866

0.2143

0.4107

$\begin{array}{lll}0.1714 & 0.3770\end{array}$

0.1794

0.3838

0.142

0.1250

0.3503

$0.2227 \quad 0.4161$

0.2500

0.4331

0.2976

0.3310

0.1892

0.3918

0.1589

0.3657

0.2289

0.4202

0.4577

$0.2270 \quad 0.4190$

\begin{abstract}
0.2202
0.4148
\end{abstract}

\begin{abstract}
0.2289
\end{abstract}


Employed Pre-Migration

$0.2540 \quad 0.4357$

Migration Destination:

Pakistan

$0.7163 \quad 0.4513$

Iran

$0.2837 \quad 0.4513$

Migration Duration

(years)

$12.36 \quad 7.54$

Remittances Sent (y/n)

$0.0536 \quad 0.2254$

Return Period:

1992-2001

$0.5040 \quad 0.5005$

2002-2011

$0.4960 \quad 0.5005$

Time Since Returned

(years)

$10.22 \quad 5.11$

Return Reason:

Political/Security

$0.7321 \quad 0.4433$

Log of Return Savings

$1.6252 \quad 2.6422$

Return Assistance

$0.2897 \quad 0.4541$

Re-migration Intentions

$0.1925 \quad 0.3946$

Significance Levels: ${ }^{*} \mathrm{p}<0.10,{ }^{* *} \mathrm{p}<0.05,{ }^{* * *} \mathrm{p}<0.01$.

\section{$5.4 \quad$ Results}

In presenting our empirical results, we begin with an examination of self-selection into return migration before moving on to the occupational choice models. With all models we report the relative risk ratio, or marginal effect in the case of the probit model, along with robust standard errors in parentheses.

To examine self-selection into return, Table 19 reports the likelihood estimate that an individual is a return migrant using a probit model, as well estimates for two separate specifications of the occupational choice model which includes in the first instance a return migrant dummy variable, and in the second the generalized residual from the initial probit model. In the first multinomial logit model we find that return migrants are on the margin 58 percent less likely to be wage employed in comparison to non-migrants. On the contrary, the estimates for both other occupational categories regarding self-employment are statistically insignificant. When adding the generalized residual in the second multinomial logit model, we find it is statistically insignificant in all three occupational choice categories 
indicating self-selection into return migration is not a concern. Furthermore, we conduct a Chow test to estimate the difference of coefficients between nonmigrants and return migrants based on occupational category. The results of the Chow test show a statistically significant chi-square value for both selfemployment in business and wage employment allowing us to reject the null hypothesis of similar coefficients for these two occupational choices. This indicates that the estimated coefficients between groups are statistically different and individual variables used in our model influence non-migrants and return migrants differently for both occupational categories. The estimated coefficients for selfemployment in agriculture or herding on the other hand are not statistically different between both groups, meaning return migration may not be influential for this occupation.

Table 20 presents our results that compare non-migrants and return migrants in regards to what influences their respective occupational choices. First and foremost, we notice significant differences in terms of individual characteristics. For instance, being the head of the household and married makes an individually more likely to be employed in any of the three categories compared to not working for both non-migrants and return migrants. Alternatively, the older an individual the slightly less prone they are to be employed no matter the occupational category or migration status.

As for educational attainment, the results paint a mixed picture. First, non-migrants with less than secondary schooling have lower odds of being employed in any of the three occupational categories, including wage employment, whereas such a negative relationship is not statistically significant when it comes to return migrants. When an individual has a secondary level of education or higher this lower likelihood of being self-employed in business amplifies for non-migrants, and is still statistically insignificant for return migrants. On the other hand, both non-migrants and return migrants with secondary education or higher are less likely to be self-employed in agriculture or herding, while results for wage employment are insignificant for both groups. Overall, these varied results suggest non-migrants with no schooling are more likely to be self-employed in either business or agriculture or herding, whereas occupational choice is less influenced by educational attainment for return migrants. 
Moving on to households characteristics, interestingly non-migrants within those households at a higher income level are more likely to be self-employed in business and wage employed, yet this result does not hold for return migrants. As to be expected both non-migrants and return migrants within households owning land have much higher odds of being involved in agriculture or herding. And finally the strength of social networks, indicated by involvement in a community organization, appears to be particularly relevant for return migrants across all occupational choices, while also significant for non-migrants in both selfemployment categories. Regarding location type, predictably both non-migrants and return migrants are less likely to be involved in agriculture or herding if located within an urban district, while return migrants are more likely to be selfemployed in business. Unexpectedly, however, non-migrants are less likely to be wage employed in urban areas in relation to rural areas.

Table 21 reports our results of the differences in occupational choice based on the migration and return experience of returnees. Nearly all of those same individual-, household- and community-level characteristics influential in the previous model are once again statistically significant, so as a matter of parsimony we only present here the migration- and return-related characteristics of interest (see Table A5.1 in the appendix for full model). First, and somewhat expectedly, we find that those individuals who were employed prior to migrating have a more than double the likelihood of being wage employed upon return. Less expected, however, given the context of forced displacement, the more years spent abroad the slightly greater the odds of being both self-employed in business and wage employed possibly indicating some sort of skill acquisition. On the other hand, returnees who originally migrated to Iran are more likely to be involved in agricultural or herding practices upon return, while the same is true regarding the number of years since return and the amount of savings brought back. Those who received assistance to return from either an international organization or government program are less likely to be wage employed, suggesting those of a lower socio-economic status and thus most likely to have been targeted for assistance have a harder time entering into wage employment. Lastly, individuals with concrete intentions to re-migrate are less likely to be occupied with agriculture or herding, possible indicating laborintensive activities such as farming necessitate greater investment in land and assets like livestock, making future movement less desirable. 


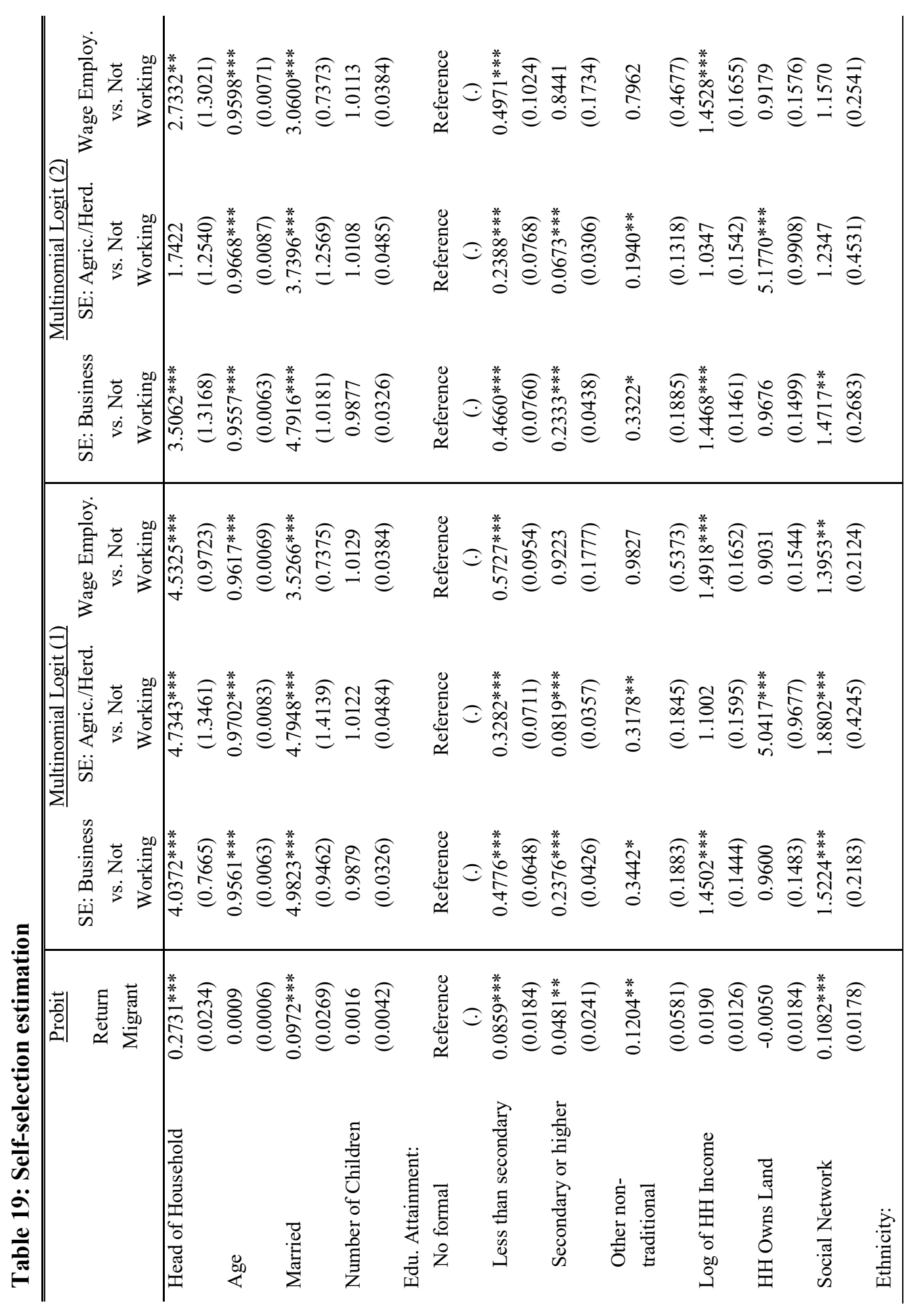




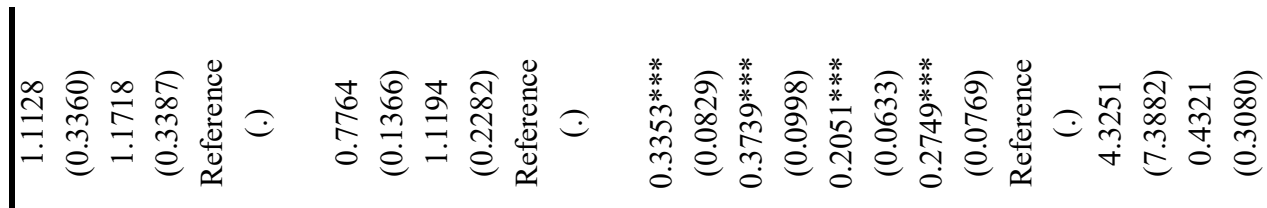



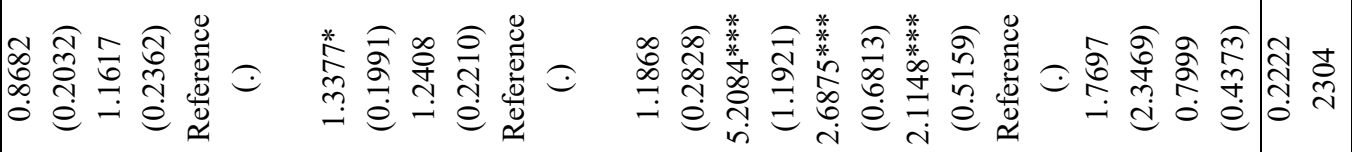

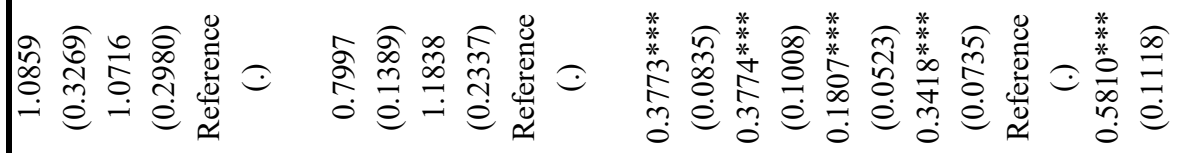

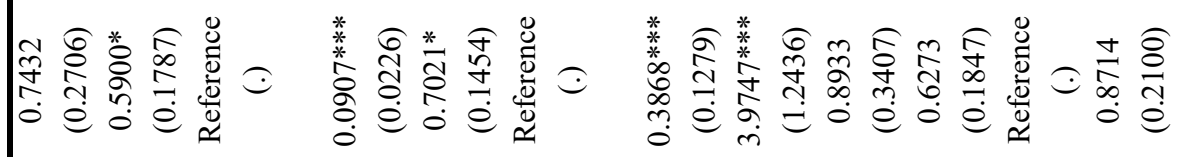

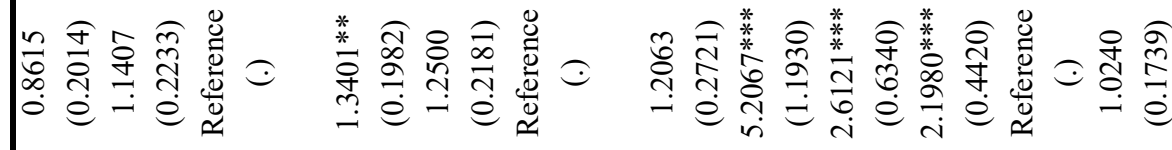

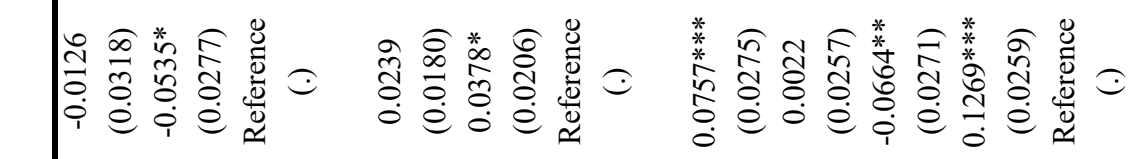

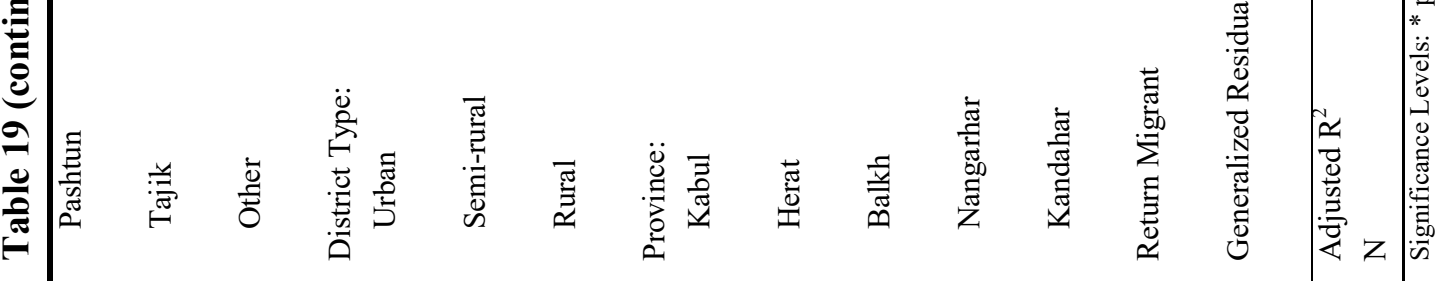




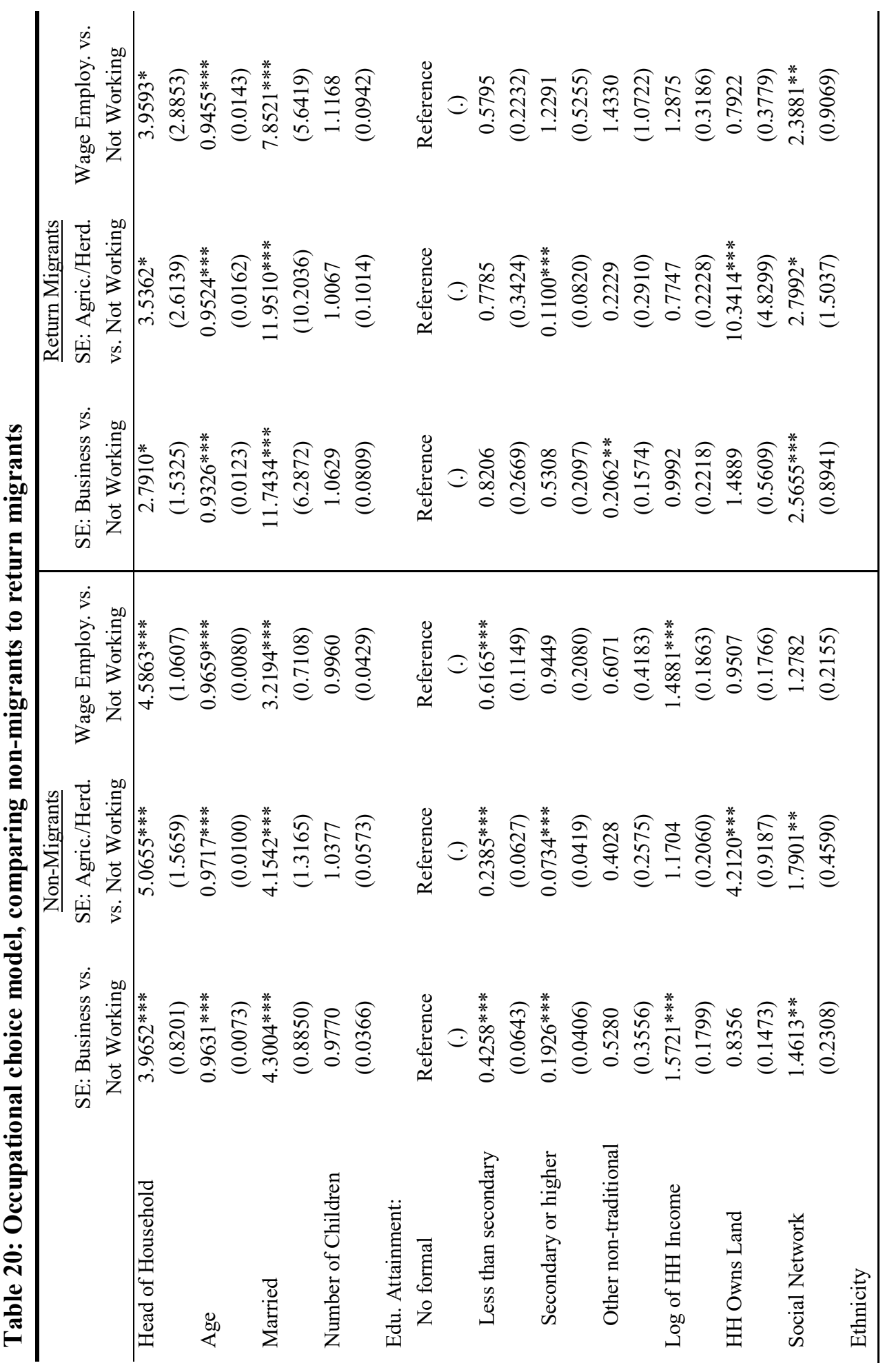




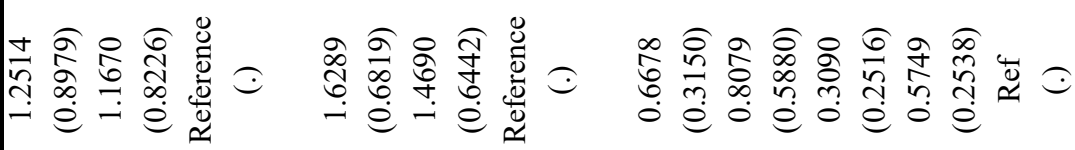

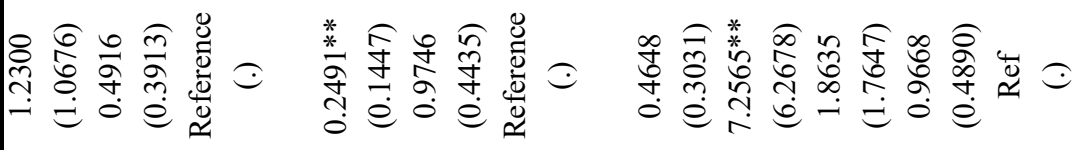

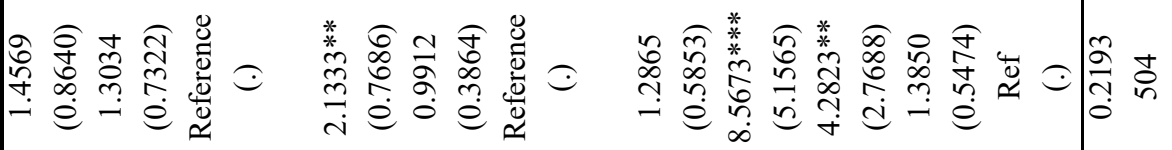

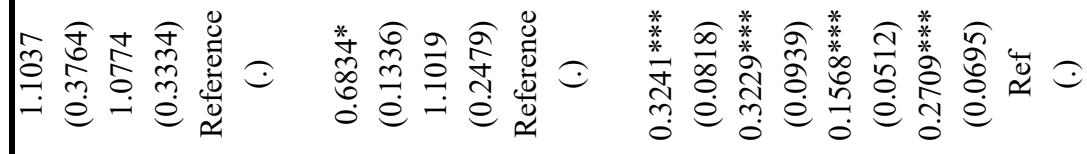

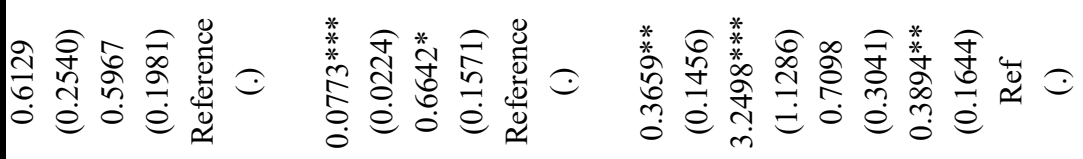

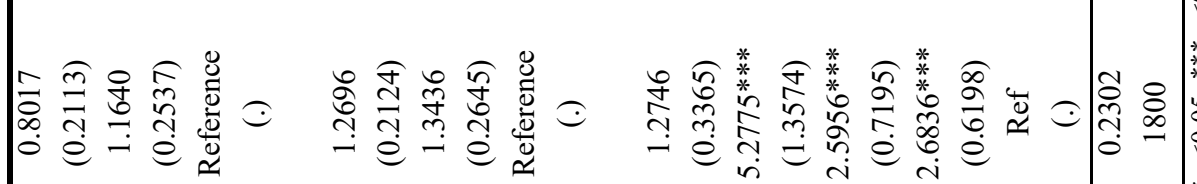



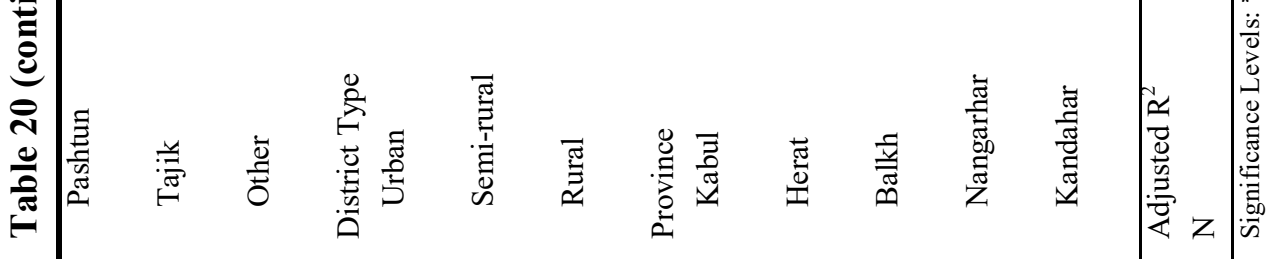


Table 21: Occupational choice model, with migration and return experience

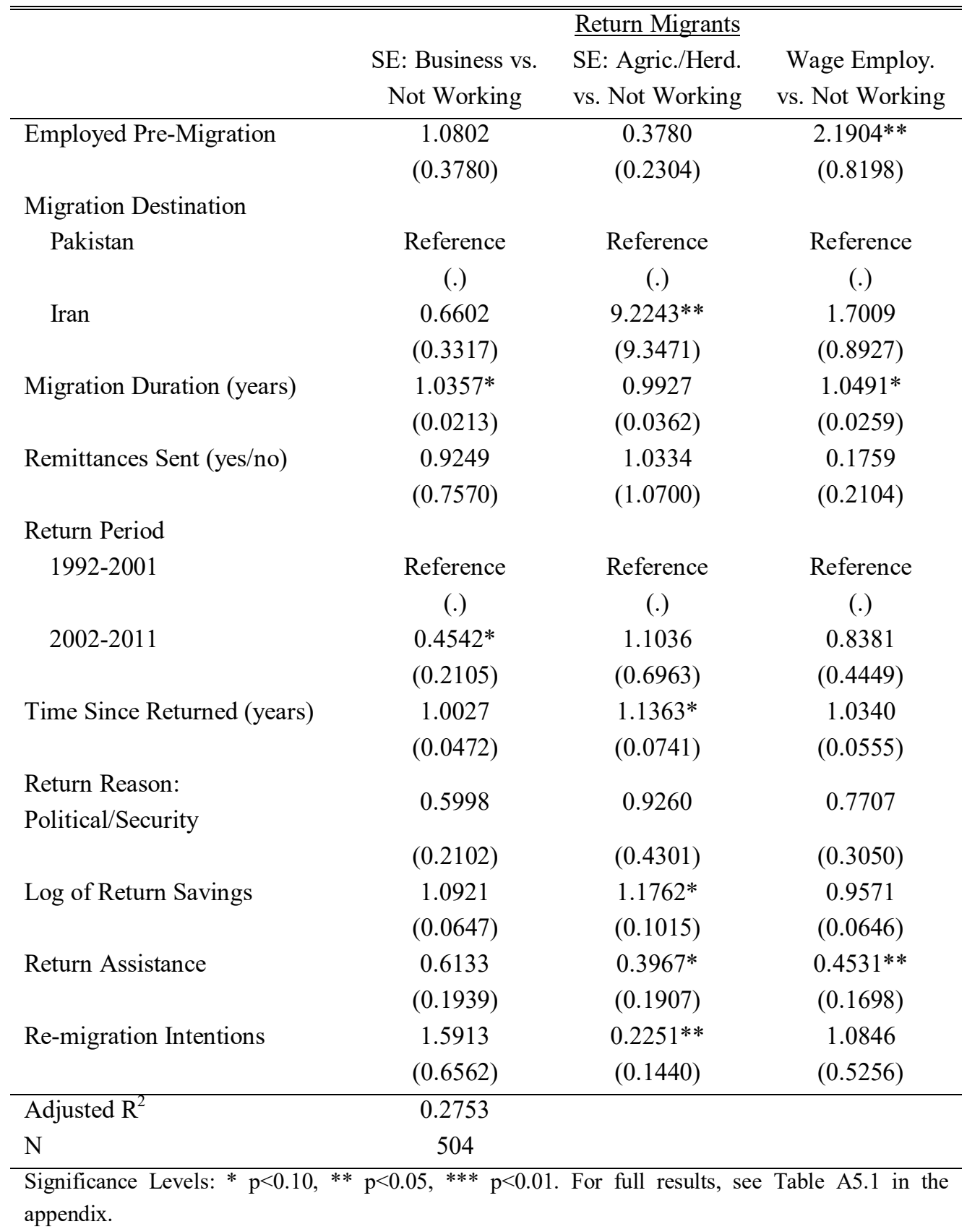




\subsection{Conclusion}

This chapter investigates the occupational choice of return migrants in Afghanistan, whose initial migration was forced due to conflict and general insecurity. We are motivated by the fact that the reintegration of returnees in a (post-) conflict setting such as Afghanistan greatly depends on their ability to access sustainable income-generating activities as a basis of their livelihood. In this regard, most case studies on record have found that return migrants are more likely than non-migrants to be self-employed rather than employed as wage labor. Such an observation, however, originates from inquiries focused principally on countries characterized by voluntary labor migration, contributing little to our understanding of the return of migrants who originally left involuntarily because of concerns for safety.

Our analytical approach is twofold: to first compare non-migrants and return migrants in regards to what influences their respective occupational choices; and second, to investigate the influence of the returnees' migration and return experience on their occupational choice. We take into consideration only those return migrants who originally migrated because of political or security concerns, or because of an environmental disaster. Moreover we test for and find no evidence of selection into return migration.

Our results indicate that return migrants are less likely to be wage employed in comparison to non-migrants. Differences in occupational choice seem to arise from dissimilarities in socio-economic status. For one, non-migrants with no schooling are more likely to be self-employed in either business or agriculture or herding, whereas occupational choice has less to do with educational attainment for return migrants. In addition, non-migrants with greater household income have greater odds of being both self-employed in business and wage employed while no such statistically significant relationship exists for return migrants. As such, we can deduce that those individuals of a higher socio-economic status are generally able to better take advantage of the already insufficient employment opportunities available, yet having left the country and since returned limits their ability. On the other hand, having a strong social network within the local community helps a return migrant's chance of employment across all categories, whereas such an effect is only seen in regards to self-employment for non-migrants. 
As for the influence of the migration and return experience on occupational choice, a few key factors are found to be of consequence. First, and somewhat expectedly, being employed prior to migrating helps raise the likelihood of being wage employed upon return. Less expected, however, given the context of forced displacement, it seems the more years spent abroad the greater the odds of being wage employed possibly pointing to some sort of skill acquisition. Moreover, and possible corresponding to the prior notion related to socio-economic status, those who received financial assistance to return from either an international organization or government program are less likely to be wage employed. On the other hand, the amount of savings brought back upon return is beneficial when it comes to becoming self-employed in both business and agriculture or herding. Finally, individuals with concrete intentions to re-migrate are less likely to be occupied with agriculture or herding, potentially indicating labor-intensive activities such as farming necessitate greater investment in land and assets including livestock, making future movement less desirable.

In light of our findings, there seem to be a number of opportunities to assist small business creation by returnees in Afghanistan with the ultimate goal of supporting sustainable return and reintegration. First, however, when thinking about possible assistance packages it is necessary to emphasize proper targeting and a logical focus on areas of high return. Programs already providing basic support to returnees (e.g. shelter assistance) currently operate in a number of provinces known for high rates of return including Nangarhar, Kabul and Lagham in the east, Kandahar in the south and Herat in the west (MGSoG \& Samuel Hall, 2013). Beyond targeting though, it is also important that assistance be meaningful to the localized context of the recipient. As the results of this study show, individuals in rural areas are much more likely to become self-employed in agriculture than in business. As such, in-kind assistance like tools, seeds or livestock are likely to enable and support these agricultural activities, whereas assistance like business training may be more appropriate in an urban context.

Given the role of social networks highlighted in our study, assistance focused on helping returnees build strategic linkages in their communities may be particularly beneficial. The capacity of return migrants, for instance, could be improved by bringing them in touch with other actors like business associations or a network of experts. Indeed a now-outdated program run by the Dutch IntEnt Foundation 
providing support to Afghan return migrants from the Netherlands had an extensive network at origin willing to help newcomers by sharing knowledge, contacts and in some cases even investments (de Haas, 2006). Moreover, a similar and currently ongoing program by the German Development Cooperation has proven to be beneficial to return migrants wanting to open a business in Morocco, Cameroon and Georgia (CIM, 2014). Additionally, our findings concerning the importance of savings suggests a possible credit constraint at home which earnings from abroad help to ease. With this in mind, small grants and/or loans for the purpose of investing in a business venture may be a viable strategy if provided to a suitable recipient with practical ideas and the capacity to carry them out. Careful selection is therefore important in order to increase the likelihood of effective implementation, but certain conditions could be put in place to help improve the odds of success including mandatory attendance to training session or membership in a business group.

Overall, assisting return migrants in their reintegration into the labor market is an important step in the process of sustainable return to a (post-) conflict environment like that of Afghanistan. In a context where wage employment is systematically limited however, self-employment may simply be the only if not best viable income-generating activity. Providing support then to a returnee for this specific purpose, whether for a business venture or agricultural endeavor, has the potential to not only improve individual welfare but also contribute to local development. 


\section{Works Cited}

Acs, Z. (2006). How is entrepreunershp good for economic growth? Innovations: Technology, Governance, Globalization, 1(1), 97 - 107.

Arif, G. M., \& Irfan, M. (1997). Return Migration and Occupational Change: The Case of Pakistani Migrants Returned from the Middle East. The Pakistan Development Review, 36(1), 1 - 37.

Bascom, J. (2005). Last Step? Reintegration of Repatrites in Eritrea. Journal of Refugee Studies, 18(2), 165 - 180.

Black, R., \& Castaldo, A. (2009). Return Migration and Entreprenuership in Ghana and Cote D'Ivoire: The Role of Capital Transfers. Tijdshrift Voor Economische En Sociale Geografie, 100(1), 44 - 58.

Black, R., \& Gent, S. (2006). Sustainable Return in Post-conflict Contexts. International Migration, 44(3), 15 - 38.

Black, R., King, R., \& Tiemoko, R. (2003). Migration, return and small entreprise development in Ghana: A route out of poverty? (Sussex Migration Working no. 9). Sussex Centre for Migration Research, University of Sussex.

Borodak, D., \& Piracha, M. (2011). Occupational Choice of Return Migrants in Moldova. Eastern European Economics, 49(4), 24 - 46.

Burt, R. (2000). The Network Entrepreneur. In R. Swedberg, Entrepreneurship: The Social Science View. Oxford: Oxford University Press.

Cassarino, J. P. (2004). Theorising return migration: The conceptual approach to return migrants revisited. International Journal of Multicultural Societies, $6(2), 253-279$.

Central Statistics Office (CSO). (2014). National Risk and Vulnerability Assessment 2011/2012. Afghanistan Living Conditions Survey. Kabul: Central Statistics Office.

Centre for International Migration and Development (CIM). (2014). Geschäftsideen für Marokko | Geschäftsideen für Entwicklung. Retrieved May 5, 2014, from <http://www.geschaefsideen-fuer-entwicklung.de/dielaender/marokko $>$.

Ciarli, T., Parto, S., \& Savona, M. (2010). Conflict and entrepreneurial activity in Afghanistan: Findings from the national risk and vulnerability assessment data. (Working Paper No. 2010/08). United Nations University World Institute for Development Economics Research (UNU-WIDER). 
de Haas, H. (2006). Engaging diasporas. How governments and development agencies can support diaspora involvement in the development of their origin countries. A study for Oxfam Novib, Oxford: International Migration Institute, University of Oxford.

de Vreyer, P., Gubert, F., \& Robilliard, A. S. (2010). Are there returns to migration experience? An empirical analysis using data on return migrants and nonmigrants in West Africa. Annals of Economics and Statistics, 307 - 328.

Desai, S. (2009). Measuring entrepreneurship in developing countries. (Research Paper No. 2009/10). United Nations University World Institute for Development Economics Research (UNU-WIDER).

Dustmann, C., \& Kirchkamp, O. (2002). The optimal migration duration and activity choice after re-migration. Journal of Development Economics, $67(2), 351-372$.

Fransen, S., \& Kuschminder, K. (2012). Back to the land: the long-term challenges of refugee return and reintegration in Burundi. (Research Paper No. 242). UNHCR.

Gladwell, C., \& Elwyn, H. (2012). Broken futures: young Afghan asylum seekers in the UK and on return to their country of origin. (Research Paper No. 246). UNHCR.

Gubert, F., \& Nordman, C. J. (2011). Return Migration and Small Enterprise Development in the Maghreb. In S. Plaza, \& D. Ratha, Diaspora for Development in Africa (pp. 103 - 126). Washington D. C.: World Bank.

Hautaniemi, P., Juntenen, M., \& Sato, M. (2013). Return Migration and Vulnerability: Case Studies from Somaliland and Iraqi Kurdistan. Helsinki: Interkont Books.

Ilahi, N. (1999). Return migration and occupational change. Review of Development Economics, 3(2), 170 - 186.

International Labour Organization (ILO). (2012). Afghanistan: Time to move to Sustainable Jobs - A Study on the State of Employment in Afghanistan. Geneva: ILO.

International Labour Organization (ILO). (2013). Assessment of Livelihood Opportunities for the Returnees/IDPs and the Host Communities. Geneva: ILO.

Kilic, T., Carletto, C., Davis, B., \& Zezza, A. (2009). Investing back home: return migration and business ownership in Albania. The Economics of Transition, 17(3), 587 - 623. 
Klagge, B., Klein-Hitpas, K., Fihel, A., Kindler, M., Matejko, E., \& Okolski, M. (2007). High-skilled Return Migration and Knowledge-based Economic Development in a Regional Perspective: Conceptual Considerations and the Example of Poland. (CMR Working Paper 19). Centre of Migration Research, Warsaw University.

Maastricht Graduate School of Governance (MGSoG); Samuel Hall Consulting. (2013). Evaluation of the UNHCR Shelter Assistance Programme: Full Report. MGSoG.

McCormick, B., \& Wahba, J. (2001). Overseas work experience, savings and entrepreneurship amongst return migrants to LDCs. Scottish Journal of Political Economy, 48(2), 164 - 178.

Mesic, M., \& Bagic, D. (2011). Minority Return to Croatia: Study of an Open Process. UNHCR.

Mesnard, A. (2004). Temporary migration and capital market imperfections. Oxford Economic Papers, 56(2), 242 - 262.

Naudé, W. (2010). Promoting Entrepreneurship in Developing Countries. (Policy Brief 4). United Nations University World Institute for Development Economics Research (UNU-WIDER).

Novak, P. (2007). Place and Afghan Refugees: A Contribution to Turton. Journal of Refugee Studies, 20(4), 551 - 578.

Omata, N. (2012). Repatriation and Integration of Liberian Refugees from Ghana: the Importance of Personal Networks in the Country of Origin. Journal of Refugee Studies, 26(2), 265 - 282.

Organization for Economic Cooperation and Development (OECD). (2008). International Migration Outlook. Paris: OECD.

Organization for Economic Cooperation and Development (OECD). (2010). Entrepreneurship and Migrants - Report by the OECD Working Party on SMEs and Entrepreneurship. Paris: OECD.

Piracha, M., \& Vadean, F. (2010). Return migration and occupational choice: Evidence fomr Albania. World Development, 38(8), 1141 - 1155.

Reynolds, P. D., Camp, S. M., Bygrave, W. D., Autio, E., \& Hay, M. (2001). Global Entrepreneurship Monitor - 2001 Executive Report. London: Babson College/ London Business School.

Tani, M., \& Mahuteau, S. (2008). Return Migration and Working Choices. . (MIREM Project Analytical Report 1). Robert Schuman Centre for Advanced Studies, European University Institute. 
van Houte, M., \& de Koning, M. (2008). Towards a better embeddedness? Monitoring assistance to involuntary returning migrants from Western countries. Nijmegen / Amsterdam: CIDIN / AMIDSt.

Wahba, J., \& Zenou, Y. (2012). Out of sight, out of mind: Migration, entrepreneurship and social capital. Regional Science and Urban Economics, 42(5), 890 - 903. 


\section{Appendix}

Table A5.1: Occupational choice model, with migration and return experience

\begin{tabular}{lccc}
\hline \hline & $\begin{array}{c}\text { SE: Business } \\
\text { vs. Not Working }\end{array}$ & $\begin{array}{c}\text { Return Migrants } \\
\text { SE: Agric./Herd. } \\
\text { vs. Not Working }\end{array}$ & $\begin{array}{c}\text { Wage Employ. } \\
\text { vs. Not Working }\end{array}$ \\
\hline Head of Household & 2.3736 & $7.1444^{*}$ & $4.0992^{*}$ \\
Age & $(1.3386)$ & $(7.4684)$ & $(3.0769)$ \\
Married & $0.9311^{* * *}$ & $0.9537 * *$ & $0.9357^{* * *}$ \\
& $(0.0132)$ & $(0.0189)$ & $(0.0153)$ \\
Number of Children & $16.3278^{* * *}$ & $9.0210^{* *}$ & $10.9420 * * *$ \\
& $(9.1748)$ & $(9.3537)$ & $(8.3569)$ \\
& 1.0424 & 1.0410 & 1.1208 \\
& $(0.0847)$ & $(0.1224)$ & $(0.0994)$
\end{tabular}

Edu. Attainment:

No formal

Less than secondary

Secondary or higher

Other non-traditional

Log of HH Income

HH Owns Land

Social Network

Ethnicity:

Pashtun

Tajik

Other

District Type:

Urban

Semi-rural

Rural
Reference

(.)

0.7870

(0.2752)

$0.4766^{*}$

(0.1940)

$0.1974 * *$

(0.1482)

0.8806

(0.2231)

1.4823

(0.5750)

$2.7500 * * *$

(0.9816)

1.3295

(0.8269)

1.4674

(0.8599)

Reference

(.)

$$
\begin{gathered}
2.0968^{*} \\
(0.8222) \\
0.9703 \\
(0.4109)
\end{gathered}
$$

Reference

(.)
Reference

$$
\text { (.) }
$$

0.7136

(0.3447)

$0.0832 * * *$

(0.0685)

0.1732

(0.2503)

0.7907

(0.2498)

$7.6687 * * *$

(3.7922)

2.7454*

(1.6577)

1.2615

(1.1254)

0.3071

(0.2724)

Reference

(.)

$0.1855 * * *$

(0.1175)

1.4247

(0.7747)

Reference

(.)
Reference

$$
\text { (.) }
$$

0.6095

(0.2460)

1.4018

(0.6213)

1.5884

(1.1993)

1.2639

(0.3397)

0.7944

(0.3933)

$2.5720^{* *}$

(1.0175)

1.0615

(0.8133)

1.0362

(0.7606)

Reference

(.)

1.5937

(0.6836)

1.4852

(0.6853)

Reference

(.) 
Province:

$\begin{array}{lccc}\text { Kabul } & 1.6977 & 0.2669 & 0.8735 \\ & (0.8959) & (0.2218) & (0.4694) \\ \text { Herat } & 11.4055^{* * *} & 1.1524 & 0.5371 \\ & (8.6238) & (1.4485) & (0.4632) \\ \text { Balkh } & 4.9269^{* *} & 0.5417 & 0.4007 \\ & (3.4833) & (0.6640) & (0.3486) \\ \text { Nangarhar } & 1.3050 & 2.0481 & 0.5419 \\ & (0.5858) & (1.1751) & (0.2660) \\ \text { Kandahar } & \text { Reference } & \text { Reference } & \text { Reference } \\ & (.) & (.) & (.) \\ \text { Employed Pre-Migration } & 1.0802 & 0.3780 & 2.1904 * * \\ & (0.3780) & (0.2304) & (0.8198)\end{array}$

Migration Destination:

Pakistan

Reference

(.)

Reference

Reference

Iran

0.6602

(.)

(.)

(0.3317)

$9.2243 * *$

1.7009

Migration Duration (years)

$1.0357^{*}$

(9.3471)

(0.8927)

(0.0213)

0.9927

1.0491*

0.9249

(0.0362)

$(0.0259)$

Remittances Sent (yes/no)

(0.7570)

1.0334

0.1759

(1.0700)

(0.2104)

Return Period:

1992-2001

Reference

Reference

Reference

(.)

(.)

(.)

2002-2011

$0.4542 *$

1.1036

0.8381

$(0.2105)$

(0.6963)

(0.4449)

Time Since Returned (years)

1.0027

1.1363*

1.0340

(0.0472)

(0.0741)

(0.0555)

Return Reason:

Political/Security

$\begin{array}{lll}0.5998 & 0.9260 & 0.7707\end{array}$

Log of Return Savings

(0.2102)

(0.4301)

(0.3050)

1.0921

1.1762*

0.9571

(0.0647)

(0.1015)

(0.0646)

Return Assistance

0.6133

$0.3967^{*}$

$0.4531 * *$

(0.1939)

(0.1907)

(0.1698)

Re-migration Intentions

1.5913

$0.2251 * *$

1.0846

Adjusted $\mathrm{R}^{2}$

(0.6562)

(0.1440)

(0.5256)

0.2753

N 



\section{Chapter 6}

\section{Does Shelter Assistance Reduce Poverty? ${ }^{20}$}

\subsection{Introduction}

"Civil wars and conflicts arguably inflict more suffering on humanity than any other social phenomenon" (Blattman \& Miguel, 2010, p. 47). A particular consequence of armed conflict is often forced migration which imposes economically large burdens on refugee-receiving countries, represents significant losses for refugee-sending countries, entails substantial economic costs for responsible agencies like the UNHCR and UNRWA and above all, often destroys the lives of the refugees and internally displaced themselves. Should conditions in sending regions become suitably favorable, the successful return of forced migrants, therefore, may constitute a win-win-win-win scenario for the aforementioned parties. Unsurprisingly then, voluntary repatriation has all but been universally taken by many states as the durable solution of choice to the so-called global 'refugee crises' since the end of the cold war (Black \& Koser, 1999). While the process of repatriation is complex, post-return support is widely acknowledged as important in achieving sustainable return and reintegration, a key ingredient of which is the resolution of lost housing and property (Leckie, 2000; Simmons, 2001). Given the recent history of displacement in Afghanistan - the country most affected by refugee movements over past decades and home to at least 630,000 internally displaced persons (IDPs) - shelter assistance has been publicized as one of the top priorities of the Afghan government. ${ }^{21}$ In this study, we conduct the first judicious analysis of the impact of UNHCR shelter assistance on the overall wellbeing of recipient households.

\footnotetext{
${ }^{20}$ This chapter is based on: Loschmann, C., Parsons, C. R. \& Siegel, M. (2015) Does Shelter Assistance Reduce Poverty in Afghanistan? World Development, 74, 305 - 322.

${ }^{21}$ Afghanistan has a separate Ministry of Refugees and Repatriation.
} 
Forced migration is a particular issue for developing countries since they are the main source of refugees, host to over 86 percent of all refugees globally and home to the overwhelming majority of IDPs (UNHCR, 2015a). In 2013, Afghanistan remained the leading source country of refugees in the world with nearly 2.6 million of its citizens, or nine percent of its total population, registered abroad with UNHCR. The main host countries of Afghan refugees are neighboring Pakistan and Iran, 1.6 million and 800,000 respectively, although the true figure is likely far higher since equivalent numbers of unregistered refugees are also present in both countries (Tyler, 2014). Given the prevalence of return over the years, Afghanistan also lays claim to the largest refugee repatriation operation in the world (O'Leary, 2014). Moreover, the available data for IDPs show that even though the number of internally displaced declined rapidly post-2001 after reaching a high of 1.2 million during the early stages of the American-led offensive in the country, internal displacement has been once again steadily rising since the revival of the Taliban insurgency in 2006 (UNHCR, 2015b).

Beyond the prevalence of forced migration in Afghanistan, it is important to also take into account the everyday living conditions of the population which are among the worst in the world. In particular, the most recent National Risk and Vulnerability Assessment in 2011/2012 details stagnation or deterioration in regards to food security and overall poverty. The report estimates that nearly one third of the population, some 7.6 million people, have insufficient caloric intake; while one fifth, 4.9 million people, have insufficient protein consumption (CSO, 2014). Such chronic malnutrition among Afghan children - one of the world's highest - leads to stunting ${ }^{22}$, lower lifetime productivity and in turn lower economic growth (Alderman et al., 2006; Bundervoet et al., 2008).

In this study, we draw on unique survey data collected in 2012 to evaluate UNHCR's shelter assistance program in Afghanistan between 2009 and 2011. The program's objective has been to contribute to sustainable return and reintegration through improvements to the socio-economic condition as well as livelihood potential of benefiting households. Despite their perceived importance in various

\footnotetext{
${ }^{22}$ UNICEF (2009, p. 11) reports that Afghanistan has the highest prevalence of stunting in the world among children under five years old.
} 
contexts, shelter assistance interventions have yet to be subjected to rigorous assessment. Where evaluations have been carried out (UNHCR, 2005; Ferretti \& Ashmore, 2010; GHK Consulting, 2012), little effort has been made to establish causal inference. Our analysis uses propensity score matching techniques given the non-randomness of the treatment group to consider the broader impact of shelter assistance on household well-being. Our primary objective is to assess whether shelter assistance realizes UNHCR's aims of improving socio-economic conditions and strengthening the livelihood potential of beneficiary households. To this end, we adopt a multidimensional approach to poverty measurement, one based upon three principal dimensions: economic welfare, health and education and basic services, before delving further into the various constituent elements of these measurements in order to gain a holistic understanding of the impact.

Our study contributes to the literatures on migrant/refugee return, civil conflict and impact evaluation. In terms of the return literature, it is more closely related to scholarly work exploring the voluntary return of refugees and asylum-seekers (see, e.g., Black \& Koser, 1999; Koser, 2001; Black et al., 2004; Black \& Gent, 2006) albeit differentiated by empirically testing the impact of post-return programs as opposed to discussing them more broadly - in comparison with the economics literature on return for example, which focuses, although not exclusively, upon the conditions under which migrants return home (see, e.g., Stark, 1992; Dustmann, 1997; Bijwaard et al., 2014). As for the burgeoning economic literature on civil conflict concerning predominately the causes and consequences of war (see, e.g., Blattman \& Miguel, 2010), this chapter speaks indirectly to both. First, by assessing the efficacy of shelter programs in Afghanistan we examine one type of policy that attempts to deal with a common consequences of civil conflict, forced migration. Second, since post-return programs also aim to reduce poverty, if successful they could also be argued to be an important ingredient in reducing the probability of future conflict. Lastly, this study also contributes to the voluminous literature on impact evaluations using household level data (see, e.g., Banerjee \& Duflo, 2011). While myriad publications examine the poverty reducing effects of for example agricultural (Becerril \& Abdulai, 2010), infrastructure (Jalan \& Ravallion, 2003) and microfinance (Imai \& Azam, 2010) projects; to our knowledge this is the first study to evaluate shelter assistance in a (post-) conflict environment where the absence of basic shelter and land is routinely noted as a significant concern (Kronenfeld, 2008; Reed \& Foley, 2009). Moreover, this is one 
of few early applications of a multidimensional approach towards poverty measurement for an impact evaluation (see, e.g., Robano \& Smith, 2013).

Our results provide evidence that shelter assistance has had a statistically significant poverty reducing effect. This is all the more important since some believe, despite large aid inflows to Afghanistan post-2001, that foreign assistance has had a negligible impact on poverty levels (O'Leary, 2014). From a multidimensional perspective, beneficiary households are three percentage points less poor than their non-beneficiary counterparts. Moreover, beneficiaries are between five and six percentage points less deprived in terms of dietary diversity, food security and heating. Given the prevalence of chronic malnutrition throughout Afghanistan, these results regarding food security and dietary diversity are particularly encouraging. However, when taking into account the insignificant effect on indicators related to economic well-being, one must come to terms with the fact that the program may have fallen short of its own overly-ambitious objectives, namely to greatly improve the socio-economic condition and thus livelihood potential of benefiting households.

The remainder of this chapter is structured as follows. In the next section we briefly provide details of the UNHCR shelter assistance program. In section 3 we discuss the construction of our poverty measures, and discusses our empirical strategy. We then provide the empirical results in section 4, including a sensitivity analysis, before offering concluding remarks in section 5 .

\subsection{Background}

One of the many consequences of years of conflict and displacement in Afghanistan has been the lack of housing and land due to systematic destruction, neglect and deterioration (Macdonald, 2010; 2011). Data from a number of sources estimates that around 500,000 homes have been either partially or totally destroyed (UNOCHA, 2009; UNHCR, 2011). Shelter provision is therefore perceived as a fundamental channel through which to support the livelihood potential of whole families and more generally the socio-economic development of the most adversely affected communities. Under this premise, UNHCR has established a 
shelter assistance program explicitly targeting returned refugees and IDPs in areas of high return. ${ }^{23}$ The underlying objective of this program is sustainable return and reintegration, "thereby diminishing the potential for secondary displacement, return to host countries and for disenfranchised youth to join militant or criminal networks" (UNHCR, 2012b: 2-3). Since 2002, this program has been the cornerstone of UNHCR's assistance to voluntary returnees, leading to the construction of more than 220,000 shelters.

In practice, the shelter assistance program follows a self-help model in which beneficiaries construct their own accommodation following stipulated guidelines. The main shelter design is a two-room unit which includes a corridor and external latrine. In recent years, a one-room unit or an additional room to an existing house became available to accommodate emergency situations, mostly for the internally displaced or those located in an urban setting. This variety in possible accommodation allows for greater flexibility across diverse geographical locations where beneficiaries' needs may differ. The support package mostly consists of essential construction materials (e.g. tools, roofing beams, doors, windows, etc.). Cash grants are also available on a case-by-case basis in the event that additional materials or labor are deemed necessary, however such assistance is extremely rare since UNHCR and their implementing partners are averse to a cash-based approach due to the apparent risk of misuse. ${ }^{24}$

The shelter assistance program is considered a community-based intervention such that the community itself is expected to identify eligible households and bring them to the attention of a local Beneficiary Selection Committee that comprises local

\footnotetext{
${ }^{23}$ A number of other stakeholders including the Norwegian Refugee Council (NRC), the International Organization for Migration (IOM) and UN-HABITAT have also been actively involved with shelter assistance in Afghanistan, however our focus in this paper is solely on the operations of UNHCR.

${ }^{24}$ These views are corroborated by field observations made by the in-country team and subsequently recorded in the final report, detailing, for example, that cash grants given in order to purchase high quality materials like glass windows were at times used for more immediate needs like food and water (MGSoG and Samuel Hall, 2013, p. 27).
} 
leaders and representatives of implementing partners. ${ }^{25}$ Eligibility for the program initially required potential beneficiary households to have an officially recognized ${ }^{26}$ returned refugee or IDP as a member. However, an evolving emphasis on vulnerability has gradually widened selection to incorporate other at-risk households beyond this original scope. The vulnerability criterion follows the 'extremely vulnerable individual' definition and includes those who may be in a life threatening situation, unable to help themselves and lacking family and community support or suffering from physical or mental trauma (UNHCR, 2012a).${ }^{27}$ Households that meet the vulnerability criterion but which do not contain a returned refugee or IDP are thus still eligible for assistance. Moreover, even though access to land on which to build shelter is an official requirement, those not owning land may qualify for land allocation allowing them the opportunity to be provided shelter assistance as well. As such, although returned refugees and IDPs with access to land are the official targets of the programs, in practice eligibility is much broader permitting any vulnerable household in the community to be potentially eligible for shelter assistance (MGSoG \& Samuel Hall, 2013).

While there is little doubt that shelter assistance benefits families by providing basic accommodation, whether the program on the whole contributes to poverty reduction and the broader overarching objectives of UNHCR remains an empirical question. The assumption is that by providing shelter where none is available, beneficiaries will have a socio-economic foundation from which to improve their livelihood potential (UNHCR, 2011). Given this broad ambition we adopt a multidimensional approach to poverty measurement, the subject to which we now turn.

\footnotetext{
${ }^{25}$ The role of local leaders in the selection process makes nepotism a possibility with respect to ineligible households receiving assistance. While we cannot categorially discount such practices, our matching approach should reduce any bias in our estimates due to such inappropriate selection.

${ }^{26}$ Officially recognized means the individual owns a UNHCR-issued 'voluntary repatriation form'.

${ }^{27}$ More recently the 'extremely vulnerable individual' concept has been referred to as 'persons with specific needs', yet this modest change had not yet taken place by the final year under study, 2011.
} 


\subsection{Methodology}

\section{Poverty Measures}

Our analysis takes advantage of a multidimensional approach to poverty measurement, one pioneered by the Oxford Poverty \& Human Development Initiative (OPHI) in conjunction with the United Nations Development Program (UNDP) for their Human Development Reports. The objective of measuring wellbeing or poverty - inherently two sides of the same coin - in a multidimensional manner, is to move beyond simplistic income-based measurements derived from a single variable. This type of approach is arguably more relevant for analyzing programs such as that of UNHCR, the objectives of which are multifaceted.

In taking a multidimensional approach, we implement the Alkire and Foster (2011) dual-cutoff counting method to identify a household as multidimensionally poor or otherwise (see also Alkire \& Santos, 2014). First, we apply thresholds for household deprivation detailed in Table 22 for each outcome variable, encompassing a broad set of socio-economic indicators within the dimensions of economic welfare, health and education and basic services. The indicators are chosen to be as wide-ranging as possible within the confines of the available data, while additionally encapsulating how shelter assistance might otherwise indirectly influence household well-being. The deprivation thresholds for each indicator adhere to common standards where appropriate, and where ambiguous we use normative reasoning and past literature as a guide.

Second, we then look at the joint deprivation across indicators and apply a generalized cutoff set in our case at 33 percent in order to define multidimensional poverty. ${ }^{28}$ As such, a household is considered poor if deprived in over a third of all individual indicators. Formally, the unadjusted headcount ratio $(H)$ of multidimensional poverty can be expressed as:

\footnotetext{
${ }^{28}$ While this cutoff may vary due to preference of the researcher given the particular study and context at hand, we decide on 33 percent based on normative justification that a household deprived in over a third of all weighted indicators should be categorized as poor, but also practical reasoning given our construction of the poverty measure incorporates three individual indicators in three separate dimensions.
} 


$$
\begin{aligned}
& H=\frac{1}{n} \sum_{i=1}^{n} q_{i}, \text { where } \\
& q_{i}=1 \text { if } \sum_{x=1}^{d} w_{x} i_{i x}>k .
\end{aligned}
$$

Here $n$ represents the total number of households in our sample, $q_{i}$ is a binary variable indicating household $i$ is categorized as multidimensionally poor if the aggregated and weighted indicators across all dimensions, $w_{x} i_{i x}$, are greater than the cutoff, $k$. Each dimension is equally-weighted and sums up to one, and because all three are made up of the same absolute number of indicators, all individual indicators are also equally-weighted.

Table 22: Dimensions, indicators and thresholds for household deprivation

\begin{tabular}{|lll|}
\hline & Indicator & Household is deprived if... \\
\hline Dimension 1: & -Debt Ratio & $\ldots$ the debt-to-monthly income ratio is greater than 2 \\
Economic Welfare & -Sources of Income & $\ldots$ has fewer than 2 sources of income by adults \\
& -Assets & $\ldots$ owns fewer than 2 types of assets from list of $7^{29}$ \\
\hline Dimension 2: & -Dietary Diversity & $\ldots$ has not eaten meat at least once in the last week \\
Health \& Edu. & -Food Security & $\ldots$ cannot satisfy food needs more than 3 times $/$ month \\
& -School Attendance & $\ldots$...school-aged children do not attend school \\
\hline Dimension 3: & -Electricity & $\ldots$ does not have electricity \\
Basic Services & -Clean Drinking Water & $\ldots$..does not have free and potable water \\
& -Heating & $\ldots$ does not have heating \\
\hline
\end{tabular}

Beyond the unadjusted headcount ratio, we also calculate the intensity of multidimensional poverty $(A)$ based on the average deprivation score of those households found to be multidimensionally poor. The intensity of poverty can be expressed as:

$$
\begin{gathered}
A=\frac{1}{q} \sum_{i=1}^{q} c_{i}(k), \text { where } \\
c_{i}(k)=w_{x} i_{i x} \text { if } q_{i}=1 .
\end{gathered}
$$

\footnotetext{
${ }^{29}$ List of seven possible assets include: livestock, fridge, television, radio, gas oven, bicycle and motorcycle. Moreover, if the household owns a car they are considered non-deprived on this indicator regardless.
} 
Here, $c_{i}(k)$ indicates the censored deprivation score of household $i$ if identified as multidimensionally poor, and $q$ is the total number of households defined as such. With both the unadjusted headcount ratio and intensity, we can then calculate the adjusted headcount ratio which is the product of the two:

$$
M_{0}=H \times A \text {. }
$$

As such, the adjusted headcount ratio takes into account not only the incidence of multidimensional poverty given by the unadjusted headcount ratio, but also its breadth indicated by the intensity of multidimensional poverty. In order to examine the various components of multidimensional poverty we provide each measurement: the unadjusted headcount ratio $(H)$, intensity $(A)$ and adjusted headcount ratio $\left(M_{0}\right)$, for all three dimensions separately and finally overall which we define as the multidimensional poverty index $(M P I)$.

\section{Sample}

Our analysis relies on data collected for the independent evaluation of the UNHCR shelter assistance program from 2009 to 2011. Although the paper here focuses exclusively on UNHCR operations, the survey captured data for households receiving support from a number of other organizations including NRC, IOM and UN-HABITAT. The final dataset is comprised of 3,851 households, of which 51 percent are shelter assistance beneficiaries, with geographic distribution illustrated in Figure 5. 


\section{Figure 5: Distribution of households, by province}



Note: For exact figures, see Table A6.1 in the appendix.

Summary statistics for the entire pre-matched sample based on the covariates employed in the propensity score matching are presented in Table 23. Within our sample, 52 percent is identified as a refugee returnee household while 26 percent is a non-refugee returnee household, 14 percent an IDP household and 12 percent a household with no mobility. As expected, the percentage of refugee returnee households that are beneficiaries is much higher compared to non-beneficiaries given the eligibility criteria, whereas the opposite is true for non-refugee returnee households and those with no mobility. Interestingly however, even though IDPs constitute a target group of the program, they are not more likely to be beneficiaries. Furthermore, there is a statistical difference between households owning land, and although vulnerability in principle is a key criterion of the selection process in practice there is no statistical difference between beneficiary and non-beneficiary households. 
Does Shelter Assistance Reduce Poverty?

Table 23: Summary statistics

\begin{tabular}{|c|c|c|c|c|c|c|c|}
\hline \multirow[b]{3}{*}{ Variable } & \multirow{2}{*}{\multicolumn{2}{|c|}{ Full Sample }} & \multicolumn{4}{|c|}{ Shelter Assistance } & \multirow[b]{3}{*}{ t-test } \\
\hline & & & \multicolumn{2}{|c|}{$\underline{\text { Non-Beneficiary }}$} & \multicolumn{2}{|c|}{ Beneficiary } & \\
\hline & mean & sd & mean & sd & mean & sd & \\
\hline \multicolumn{8}{|l|}{ Selection Variables } \\
\hline \multicolumn{8}{|l|}{ Subgroup Identification: } \\
\hline Refugee Returnee & 0.5179 & 0.4997 & 0.3647 & 0.4815 & 0.6655 & 0.4720 & $* * *$ \\
\hline Non-refugee Returnee & 0.2641 & 0.4409 & 0.3425 & 0.4747 & 0.1886 & 0.3913 & $* * *$ \\
\hline IDP & 0.1402 & 0.3472 & 0.1472 & 0.3544 & 0.1334 & 0.3401 & \\
\hline No Mobility & 0.1155 & 0.3196 & 0.1824 & 0.3862 & 0.0511 & 0.2202 & $* * *$ \\
\hline Land Ownership & 0.4460 & 0.4971 & 0.4232 & 0.4942 & 0.4680 & 0.4991 & $* *$ \\
\hline Extremely Vulnerable & 0.4555 & 0.4981 & 0.4502 & 0.4977 & 0.4607 & 0.4986 & \\
\hline \multicolumn{8}{|l|}{ Migration Variables } \\
\hline Migrated: Pre-2001 & 0.6698 & 0.4704 & 0.5942 & 0.4912 & 0.7426 & 0.4373 & $* * *$ \\
\hline Destination: Pakistan & 0.6982 & 0.4591 & 0.6304 & 0.4828 & 0.7634 & 0.4251 & $* * *$ \\
\hline Returned: Post-2008 & 0.2429 & 0.4289 & 0.1899 & 0.3924 & 0.2939 & 0.4557 & $* * *$ \\
\hline $\begin{array}{l}\text { Returned: Home } \\
\text { Ownership }\end{array}$ & 0.3013 & 0.4589 & 0.2608 & 0.4392 & 0.3403 & 0.4739 & $* * *$ \\
\hline \multicolumn{8}{|l|}{ Control Variables } \\
\hline HH Size & 9.1468 & 4.8160 & 8.9648 & 4.7905 & 9.3220 & 4.8353 & * \\
\hline Married & 0.8728 & 0.3332 & 0.8626 & 0.3444 & 0.8828 & 0.3218 & \\
\hline \multicolumn{8}{|l|}{ Educational Attainment: } \\
\hline No formal & 0.8036 & 0.3974 & 0.7900 & 0.4074 & 0.8166 & 0.3871 & * \\
\hline Primary & 0.1240 & 0.3296 & 0.1272 & 0.3332 & 0.1209 & 0.3261 & \\
\hline Secondary & 0.0581 & 0.2340 & 0.0660 & 0.2484 & 0.0505 & 0.2191 & * \\
\hline \multicolumn{8}{|l|}{ Ethnicity: } \\
\hline Pashtun & 0.6084 & 0.4882 & 0.6109 & 0.4877 & 0.6060 & 0.4888 & \\
\hline Tajik & 0.1163 & 0.3206 & 0.1245 & 0.3302 & 0.1084 & 0.3110 & \\
\hline Hazara & 0.0634 & 0.2438 & 0.0741 & 0.2621 & 0.0532 & 0.2244 & $* *$ \\
\hline Uzbek & 0.0334 & 0.1798 & 0.0325 & 0.1773 & 0.0344 & 0.1823 & \\
\hline Turkmen & 0.0555 & 0.2289 & 0.0568 & 0.2316 & 0.0542 & 0.2265 & \\
\hline Baloch & 0.0096 & 0.0973 & 0.0065 & 0.0803 & 0.0125 & 0.1112 & \\
\hline Other & 0.1134 & 0.3171 & 0.0947 & 0.2929 & 0.1313 & 0.3378 & $* * *$ \\
\hline \multicolumn{8}{|l|}{ Location Type: } \\
\hline Urban & 0.1882 & 0.3909 & 0.2083 & 0.4062 & 0.1688 & 0.3747 & $* *$ \\
\hline Semi-rural & 0.2068 & 0.4051 & 0.2035 & 0.4027 & 0.2100 & 0.4074 & \\
\hline Rural & 0.6050 & 0.4889 & 0.5882 & 0.4923 & 0.6212 & 0.4852 & * \\
\hline
\end{tabular}

Significance Levels: ${ }^{* * *} \mathrm{p}<0.01,{ }^{*} \mathrm{p}<.05,{ }^{*} \mathrm{p}<0.10 .128$ villages are used as covariates as well, but not reported here. 
Turning to those migration-related variables, 67 percent of our sample moved prior to the Taliban's ouster in 2001 and 70 percent went to Pakistan. Differences based on shelter assistance are statistically significant for both groups and favor beneficiary households. Some 24 percent of returnees made their way back in the most recent period between 2009 and the time of survey in 2012, with a higher percentage becoming beneficiaries than those returning prior. And finally 30 percent of returnees owned a single-family house or apartment upon return, with beneficiaries being statistically more likely than their non-beneficiary counterparts. Such a finding is surprising considering the aim of the program is to provide shelter when none is available and may point to local corruption, and makes controlling for such differences in initial housing important for our analysis.

As for more general control variables, beneficiaries' household size is slightly higher in comparison to non-beneficiary households, both around nine members though, while around the same percentage of both groups are married. The vast majority of households have no formal education although this number is slightly higher for beneficiaries. Most households identify as Pashtun although there is no statistical difference in receiving shelter assistance, while the Hazara are slightly less likely to receive assistance and 'others' more so. Lastly, urban households are less likely to benefit from the shelter program while the opposite is true for rural households, a finding unsurprising given the programs' stated focus on rural areas with high rates of return.

Table 24 presents the average amount of household deprivation along each indicator for the entire pre-matched sample. Beginning with Dimension 1: Economic Welfare, around three-quarters of the entire sample is deprived in terms of both debt ratio and the number of income sources, and just over a half has less than two types of assets from the list of seven. There is no statistical difference between non-beneficiary households compared to beneficiary households for each indicator. Along Dimension 2: Health \& Education, under half of all households have not eaten meat within the last week, however this percentage is almost nine percentage points greater for non-beneficiaries. Over a third of households have problems satisfying food needs more than three times per month, again with this amount statistically greater for those not benefitting in the program. And a little more than a half do not send school-aged children to school, with the amount similar across groups. Lastly within Dimension 3: Basic Services, just under of half 
of all households have no electricity, around a sixth have no free, potable water, and just under a third have no heating. There is no statistical difference between groups among any of these last three indicators.

Table 24: Household deprivation

\begin{tabular}{|c|c|c|c|c|}
\hline & \multirow[t]{2}{*}{$\underline{\text { Full Sample }}$} & \multicolumn{2}{|c|}{ Shelter Assistance } & \multirow[b]{2}{*}{ t-test } \\
\hline & & $\underline{\text { Non-Beneficiary }}$ & Beneficiary & \\
\hline \multicolumn{5}{|l|}{ Dimension 1: Economic Welfare } \\
\hline $\begin{array}{l}\text { Debt-to-monthly income ratio is } \\
\text { greater than } 2\end{array}$ & $73.64 \%$ & $74.32 \%$ & $72.99 \%$ & \\
\hline Less than 2 sources of income & $76.11 \%$ & $76.29 \%$ & $75.94 \%$ & \\
\hline Less than 2 types of assets & $53.54 \%$ & $53.95 \%$ & $53.15 \%$ & \\
\hline \multicolumn{5}{|l|}{ Dimension 2: Health \& Education } \\
\hline No meat eaten in the last week & $43.47 \%$ & $47.96 \%$ & $39.17 \%$ & $* * *$ \\
\hline $\begin{array}{l}\text { Problems satisfying food needs more } \\
\text { than } 3 \text { times/month }\end{array}$ & $36.20 \%$ & $39.05 \%$ & $33.47 \%$ & $* * *$ \\
\hline $\begin{array}{l}\text { No school attendance for school- } \\
\text { aged children }\end{array}$ & $53.57 \%$ & $54.69 \%$ & $52.49 \%$ & \\
\hline \multicolumn{5}{|l|}{ Dimension 3: Basic Services } \\
\hline No electricity & $47.91 \%$ & $47.06 \%$ & $48.73 \%$ & \\
\hline No free, potable water & $15.45 \%$ & $16.45 \%$ & $14.50 \%$ & \\
\hline No heating & $29.94 \%$ & $31.03 \%$ & $28.89 \%$ & \\
\hline
\end{tabular}

Significance Levels: ${ }^{* * *} \mathrm{p}<0.01,{ }^{*} \mathrm{p}<.05,{ }^{*} \mathrm{p}<0.10$.

Following our calculation of the average amount of household deprivation for each indicator, we next take into consideration the joint deprivations. Table 25 provides the unadjusted headcount ratio $(H)$ and intensity $(A)$ of multidimensional poverty, resulting in the adjusted headcount ratio $\left(M_{0}\right)$ for each dimension and across all dimensions. When looking across dimensions, we are presented with overall multidimensional poverty measurements, the last of which is considered the multidimensional poverty index (MPI). All calculations are based on the earlier explained 33 percent cutoff, meaning a household is classified as multidimensionally poor if deprived in more than a third of all indicators both within and across dimensions. 
Table 25: Unadjusted headcount ratio (H), intensity (A) and adjusted headcount ratio $\left(M_{0}\right)$

\begin{tabular}{lccc}
\hline \hline & $H$ & $A$ & $M_{0}$ \\
\hline Dimension 1: Economic Welfare & $74.63 \%$ & $27.24 \%$ & 0.2033 \\
Dimension 2: Health \& Education & $41.29 \%$ & $25.44 \%$ & 0.1050 \\
Dimension 3: Basic Services & $21.76 \%$ & $22.86 \%$ & 0.0497 \\
\hline Overall Multidimensional Poverty & $67.05 \%$ & $58.48 \%$ & 0.3921 \\
\hline
\end{tabular}

Table 26 assesses the differences in overall multidimensional poverty based on receiving shelter assistance or not, broken down by each of the three poverty measurements. We find over two-thirds of all households in our sample are considered multidimensionally poor across all dimensions, with this percentage statistically higher for non-beneficiaries. On the other hand, the breadth of poverty of those considered multidimensionally poor is rather similar even though slightly higher for non-beneficiaries. Lastly, when taking the two components together we see the multidimensional poverty index is statistically greater for non-beneficiaries.

\section{Table 26: Overall multidimensional poverty}

\begin{tabular}{lccccc}
\hline \hline & Full Sample & & \multicolumn{2}{c}{ Shelter Assistance } \\
& & & Non-Beneficiary & Beneficiary & t-test \\
\hline Headcount Ratio $(H)$ & $67.05 \%$ & $69.60 \%$ & $64.60 \%$ & $* * *$ \\
Intensity $(A)$ & $58.48 \%$ & $59.05 \%$ & $57.88 \%$ & $*$ \\
\hline Multidim. Poverty Index $(M P I)$ & 0.3921 & 0.4110 & 0.3739 & $* * *$ \\
\hline
\end{tabular}

Significance Levels: $* * * \mathrm{p}<0.01,{ }^{*} \mathrm{p}<.05,{ }^{*} \mathrm{p}<0.10$.

By decomposing the multidimensional poverty measurements by province, we are able to assess geographic differences across the country where data is available. Noticeable, even though the headcount ratio $(H)$, illustrated in Figure A6.1 of the appendix, varies considerable across provinces from about 47 percent in Bamyan to 95 percent in Takhar, the intensity of multidimensional poverty $(A)$ when taking into consideration joint deprivation, illustrated in Figure A6.2, is more concentrated between 52 percent and 63 percent. When combining these two measurements to construct the overall MPI, Figure 6 shows households in Takhar and Sari Pul are relatively poorer than all others, while those in Bamyan and Paktya in comparison are considered better off. 


\section{Figure 6: Multidimensional poverty index (MPI), by province}

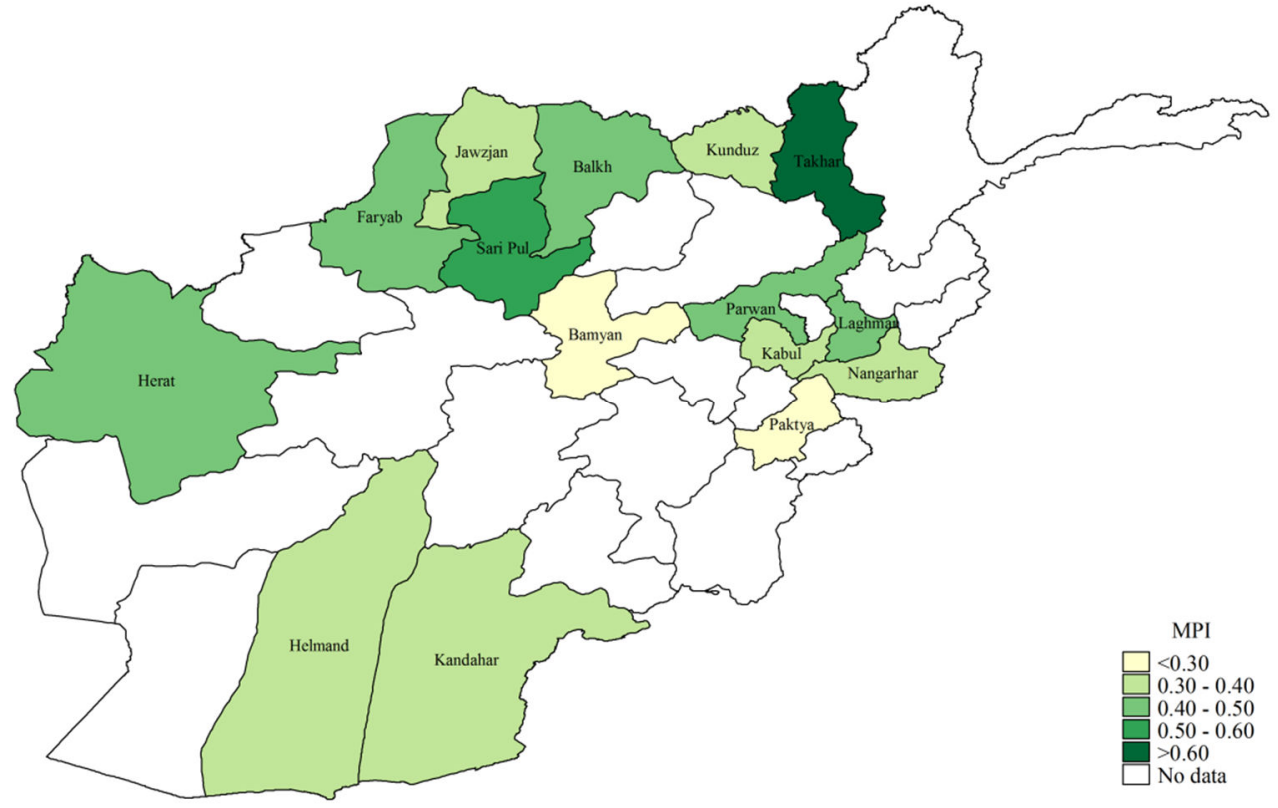

\section{Empirical Approach}

Given the objective here is to not simply calculate multidimensional poverty measurements for our sample, but rather to estimate the effect of UNHCR's shelter assistance program on those measurements, we now turn to the empirical approach. Because participation in the program was not random, our estimation strategy makes use of propensity score matching to minimize inherent selection bias. While selection bias arises from the fact that on paper assistance was targeted at a nonrandom population, in practice selection into the shelter assistance program was much more broad-based and less systematic than expected, minimizing bias even before matching. Ultimately, the parameter of interest is the average treatment effect on the treated (ATET), i.e. the change in outcome for a particular household that received assistance in comparison with that same household if they had hypothetically not received assistance. The ATET is formally expressed as:

$$
A T E T=E\left(\Delta Y_{i} / T_{i}=1\right)=E\left(Y_{i, 1} \mid T_{i}=1\right)-E\left(Y_{i, 0} \mid T_{i}=1\right)
$$


where $Y_{i, 1}$ and $Y_{i, 0}$ indicate the potential outcomes of treated household $i$, while $T_{i}=1$ denotes observed treatment. Since we do not observe $E\left(Y_{i, 0} \mid T_{i}=1\right)$, we generate an appropriate counterfactual.

Propensity score matching is a two stage procedure. First, the predicted probability, or propensity score, that a household is selected into treatment is calculated from a series of observed characteristics, which is then used to match each treated observation with one or more controlled observations based on one of a variety of matching techniques. As long as two crucial conditions are met, unconfoundedness and presence of common support, a multivariate regression analysis is able to provide an estimate of the treatment effect on the treated with minimized bias due to selection (Rosenbaum and Rubin, 1983). ${ }^{30}$

In the first-stage to estimate the predicted probability of a household receiving treatment, we employ a probit regression model based on pre-treatment characteristics expressed as:

$$
\operatorname{Pr}\left(T_{i}=1 \mid X_{i}\right)=\phi \beta_{i} X_{i}
$$

\footnotetext{
${ }^{30}$ Unconfoundedness can be formally expressed as:

$$
Y_{i, 0}, Y_{i .1} \perp T_{i} / X_{i}
$$

and indicates potential outcomes are independent of treatment conditional on the pre-treatment characteristics, $X_{i}$. The unconfoundedness condition is satisfied if no unobservable factors contribute to a 'hidden bias' in our estimates. Even though it is not possible to directly test whether the unconfoundedness condition is satisfied or not, a sensitivity analysis following, for example, Rosenbaum's (2002) bounding approach helps to provide insight.
}

The second condition, the presence of common support, can be formally expressed as:

$$
0<\operatorname{Pr}\left(T_{i}=1 / X_{i}\right)<1
$$

and assures there are sufficient comparable treatment and control observations on which to make the assessment. Our ability to construct this artificial counterfactual is assisted by the lack of systematic selection into the shelter assistance program as mentioned prior, given the fact that official eligibility criteria for shelter assistance were not dutifully followed resulting in greater randomization than expected. As such, there is ample overlap, or area of common support, between the beneficiary and non-beneficiary groups on observable characteristics to make comparison. 
where $T_{i}$ is the binary dependent variable indicating whether household $i$ received shelter assistance. $X_{i}$ indicates a series of covariates comprising not only official program selection criteria, but also migration-related indicators and more general household characteristics as controls. These include subgroup identification (e.g. refugee returnee, IDP, etc.), whether the household owns land and whether the household is deemed extremely vulnerable. In practice, a household is considered extremely vulnerable if they fall into any of the following categories: unaccompanied elderly (over 60), unaccompanied minor (under 18), physically disabled, mentally disabled, female-headed, elderly-headed, child-headed, chronically ill, survivor of gender-based violence, large family (five or more children) and no livelihoods, very low income, single parent or drug addict. As for the migration-related characteristics, we include aspects of timing since migrants moving within and from Afghanistan at various times could have been selected due to the prevailing circumstances during that moment, as well as a simple dummy indicating whether their movement was to Pakistan as it was in the majority of cases. General household characteristics include household size, marital status, educational attainment, ethnicity, location type and village. The choice of control variables stems from our understanding that certain households are more likely to be selected into treatment outside of the official criteria. For example, households in certain villages may have a higher likelihood to receive assistance based on the areas' high rate of return and thus targeting by UNHCR and implementing partners. Lastly, $\beta_{i}$ represents the regression parameter to be estimated, and $\phi$ is the cumulative normal distribution function.

Following estimation of the propensity score, a number of matching techniques are applied to appropriately link treatment and control households. For robustness, we compare the results of nearest-neighbor matching, kernel-based matching and radius matching. The nearest-neighbor method matches treatment and control observations based on the closest propensity score. By including replacement of the control unit we allow a control observation to be linked to more than one treatment observation, and set a caliper restricting the closest match to within a certain distance. Kernel-based matching on the other hand uses a weighted average that is inversely proportional to the distance between the propensity scores of the treated observation to all control observations. Radius matching similarly restricts matches to within a certain distance but instead uses all comparison members 
within that distance, allowing for oversampling when more than one good match exists without the risk of a bad match (Caliendo \& Kopeinig, 2008).

Once generating a balanced match between treatment and control observations on an area of common support, we then run a multivariate regression model to ascertain the ATET for each outcome:

$$
\text { Outcome }_{i}=\beta_{0}+\beta_{1} T_{i}+\beta_{2} X_{i}+u_{i}
$$

where Outcome $_{i}$ is any one of the poverty measurements of interest; $T_{i}$ is treatment indicating shelter assistance; $X_{i}$ is the vector of pre-characteristic control variables already mentioned; and $u_{i}$ is an error term.

\subsection{Results}

We begin by estimating the predicated probability of treatment, or propensity score, and proceed to use the three separate matching techniques to link treatment and control observations on an area of common support. The three techniques employed are nearest-neighbor matching with replacement and a caliper set at 0.04, kernel-based matching using Epanechnikov kernel weights and radius matching using the same caliper of $0.04 .^{31}$ Once matched, the difference between treated and control households is the average treatment on the treated.

Table A6.2 in the appendix presents our first-stage results from a probit model determining the predicted probability, or propensity score, that a household benefits from shelter assistance. ${ }^{32}$ We report marginal effects and t-statistics are provided in parentheses. As mentioned, our model includes both official selection criteria as well as more generalized control variables, including 128 village dummy variables which are not reported. Similar to that seen in the summary statistics, households containing a return refugee are 19 percent more likely to receive shelter

\footnotetext{
${ }^{31}$ We set the caliper following the rule of thumb that the optimal width is 0.20 of the standard deviation of the predicted probability model (Austin, 2011).

32 See Figure A6.3 in the appendix for a visual representation of the pre-matched density of the propensity score for both non-beneficiary (control) and beneficiary (treatment) observations.
} 
assistance, whereas those with an IDP are no more likely. Households categorized as extremely vulnerable are just three percent more likely to benefit in comparison to those not considered vulnerable. Households with a return migrant making their way back after 2008 are five percent more likely to be a beneficiary, as are those who owned a home upon return and have larger households. Ceteris paribus, Pashtuns and Tajiks are less likely to receive assistance relative to the reference group 'other', while urban households are more likely than their rural counterparts. No statistical significant differences are found for other ethnic groups or households located in a semi-rural location type.

Table 27 presents several tests of the balancing powers for each of the three matching methods. ${ }^{33}$ In comparing the before and after mean- and medianabsolute-standardized-biases, we notice each dropping considerably after matching, with both kernel-based and radius techniques offering the lowest biases. The fact that the bias before matching was not high suggests low systematic selection of beneficiaries in practice, providing evidence that treatment was originally more random than expected. Furthermore, the p-values corresponding to the likelihoodratio test of joint significance always rejects joint significance following matching. The relatively low pseudo- $\mathrm{R}^{2}$ along each specification provides further evidence that there is no systematic difference between treatment and control observations after matching.

\section{Table 27: Balance statistics}

\begin{tabular}{lccccc}
\hline \hline Sample & Pseudo R2 & LR chi2 & $\mathrm{p}>$ chi2 & Mean Bias & Median Bias \\
\hline Raw & 0.14 & 739.63 & 0.00 & 5.60 & 3.50 \\
Matched & & & & & \\
$\quad$ Nearest-neighbor & 0.02 & 108.76 & 0.96 & 2.20 & 1.90 \\
Kernel-based & 0.01 & 38.26 & 1.00 & 1.30 & 1.10 \\
Radius & 0.01 & 38.82 & 1.00 & 1.40 & 1.00 \\
\hline
\end{tabular}

Note: nearest-neighbor matching uses 2 neighbors within a caliper of 0.40 ; kernel-based matching uses an Epanechnikov kernel; radius matching within a caliper of 0.40 .

\footnotetext{
${ }^{33}$ See Figure A6.4 in the appendix for an illustration of the matching based on the propensity score.
} 
Table 28 provides the average treatment effect on the treated (ATET) of shelter assistance on the adjusted headcount ratio $\left(M_{0}\right)$ as it is the product of both the incidence and intensity of multidimensional poverty. We find robust evidence across all matching techniques that shelter assistance beneficiaries are better off in terms of multidimensional poverty indicated by the outcome variable MPI. Across matching specifications, beneficiary households are around three percentage points less multidimensionally poor with a high degree of statistical significance. The two dimensions in which beneficiaries are better off are Dimension 2: Health \& Education and Dimension 3: Basic Services, by around two and one percentage points respectively.

Table 28: $A T E T$ of the adjusted headcount ratio $\left(M_{0}\right)$

\begin{tabular}{|c|c|c|c|c|c|c|}
\hline Match. Meth. & Outcome & ATET & S.E. & t-stat & $\mathrm{N}$ : treat & $\mathrm{N}$ : contr. \\
\hline \multirow[t]{4}{*}{$\begin{array}{l}\text { Nearest- } \\
\text { neighbor }\end{array}$} & $\begin{array}{l}\text { Dim1: Economic } \\
\text { Welfare }\end{array}$ & -0.0039 & 0.0059 & -0.65 & 1905 & 1810 \\
\hline & $\begin{array}{l}\text { Dim2: Health \& } \\
\text { Education }\end{array}$ & -0.0153 & 0.0061 & $-2.49 * *$ & 1905 & 1810 \\
\hline & $\begin{array}{l}\text { Dim3: Basic } \\
\text { Services }\end{array}$ & -0.0107 & 0.0046 & $-2.32 * *$ & 1905 & 1810 \\
\hline & Overall MPI & -0.0316 & 0.0137 & $-2.31 * *$ & 1905 & 1810 \\
\hline \multirow[t]{4}{*}{ Kernel-based } & $\begin{array}{l}\text { Dim1: Economic } \\
\text { Welfare }\end{array}$ & -0.0041 & 0.0051 & -0.80 & 1905 & 1810 \\
\hline & $\begin{array}{l}\text { Dim2: Health \& } \\
\text { Education }\end{array}$ & -0.0182 & 0.0053 & $-3.44 * * *$ & 1905 & 1810 \\
\hline & $\begin{array}{l}\text { Dim3: Basic } \\
\text { Services }\end{array}$ & -0.0087 & 0.0039 & $-2.22 * *$ & 1905 & 1810 \\
\hline & Overall MPI & -0.0339 & 0.0119 & $-2.85 * * *$ & 1905 & 1810 \\
\hline \multirow[t]{4}{*}{ Radius } & $\begin{array}{l}\text { Dim1: Economic } \\
\text { Welfare }\end{array}$ & -0.0041 & 0.0052 & -0.80 & 1905 & 1810 \\
\hline & $\begin{array}{l}\text { Dim2: Health \& } \\
\text { Education }\end{array}$ & -0.0181 & 0.0053 & $-3.41 * * *$ & 1905 & 1810 \\
\hline & $\begin{array}{l}\text { Dim3: Basic } \\
\text { Services }\end{array}$ & -0.0088 & 0.0039 & $-2.24 * *$ & 1905 & 1810 \\
\hline & Overall MPI & -0.0340 & 0.0120 & $-2.85 * * *$ & 1905 & 1810 \\
\hline
\end{tabular}

Note: nearest-neighbor matching uses 2 neighbors within a caliper of 0.40 ; kernel-based matching uses an Epanechnikov kernel; radius matching within a caliper of 0.40. Significance Levels: $* * * \mathrm{p}<0.01, * * \mathrm{p}<.05,{ }^{*} \mathrm{p}<0.10$. 
Does Shelter Assistance Reduce Poverty?

Table 29: ATET of the unadjusted headcount ratio $(H)$

\begin{tabular}{|c|c|c|c|c|c|c|}
\hline Match. Meth. & Depriv. Outcome & ATET & S.E. & t-stat & $\mathrm{N}$ : treat. & $\mathrm{N}$ : contr. \\
\hline \multirow{9}{*}{$\begin{array}{l}\text { Nearest- } \\
\text { neighbor }\end{array}$} & Debt Ratio & 0.0044 & 0.0206 & 0.21 & 1905 & 1810 \\
\hline & $\begin{array}{l}\text { Sources of } \\
\text { Income }\end{array}$ & 0.0199 & 0.0202 & 0.98 & 1905 & 1810 \\
\hline & Assets & -0.0305 & 0.0233 & -1.31 & 1905 & 1810 \\
\hline & Dietary Diversity & -0.0497 & 0.0233 & $-2.13 * *$ & 1905 & 1810 \\
\hline & Food Security & -0.0487 & 0.0227 & $-2.15^{* *}$ & 1905 & 1810 \\
\hline & $\begin{array}{l}\text { School } \\
\text { Attendance }\end{array}$ & -0.0154 & 0.0234 & -0.66 & 1905 & 1810 \\
\hline & Electricity & -0.0229 & 0.0235 & -0.98 & 1905 & 1810 \\
\hline & Water & 0.0027 & 0.0167 & 0.16 & 1905 & 1810 \\
\hline & Heating & -0.0640 & 0.0220 & $-2.91 * * *$ & 1905 & 1810 \\
\hline \multirow[t]{9}{*}{ Kernel-based } & Debt Ratio & -0.0089 & 0.0178 & -0.50 & 1905 & 1810 \\
\hline & $\begin{array}{l}\text { Sources of } \\
\text { Income }\end{array}$ & 0.0288 & 0.0172 & 1.67 & 1905 & 1810 \\
\hline & Assets & -0.0264 & 0.0203 & -1.30 & 1905 & 1810 \\
\hline & Dietary Diversity & -0.0620 & 0.0202 & $-3.07 * * *$ & 1905 & 1810 \\
\hline & Food Security & -0.0526 & 0.0197 & $-2.68 * * *$ & 1905 & 1810 \\
\hline & $\begin{array}{l}\text { School } \\
\text { Attendance }\end{array}$ & -0.0159 & 0.0203 & -0.78 & 1905 & 1810 \\
\hline & Electricity & -0.0121 & 0.0203 & -0.59 & 1905 & 1810 \\
\hline & Water & 0.0035 & 0.0148 & 0.24 & 1905 & 1810 \\
\hline & Heating & -0.0573 & 0.0188 & $-3.04 * * *$ & 1905 & 1810 \\
\hline \multirow[t]{9}{*}{ Radius } & Debt Ratio & -0.0092 & 0.0179 & -0.51 & 1905 & 1810 \\
\hline & $\begin{array}{l}\text { Sources of } \\
\text { Income }\end{array}$ & 0.0289 & 0.0173 & 1.67 & 1905 & 1810 \\
\hline & Assets & -0.0263 & 0.0204 & -1.29 & 1905 & 1810 \\
\hline & Dietary Diversity & -0.0615 & 0.0203 & $-3.04 * * *$ & 1905 & 1810 \\
\hline & Food Security & -0.0530 & 0.0197 & $-2.69 * * *$ & 1905 & 1810 \\
\hline & $\begin{array}{l}\text { School } \\
\text { Attendance }\end{array}$ & -0.0155 & 0.0204 & -0.76 & 1905 & 1810 \\
\hline & Electricity & -0.0124 & 0.0204 & -0.61 & 1905 & 1810 \\
\hline & Water & 0.0034 & 0.0148 & 0.23 & 1905 & 1810 \\
\hline & Heating & -0.0579 & 0.0189 & $-3.06^{* * *}$ & 1905 & 1810 \\
\hline
\end{tabular}

Note: nearest-neighbor matching uses 2 neighbors within a caliper of 0.40 ; kernel-based matching uses an Epanechnikov kernel; radius matching within a caliper of 0.40. Significance Levels: $* * * \mathrm{p}<0.01, * * \mathrm{p}<.05, * \mathrm{p}<0.10$. 
Table 29 presents the ATET of shelter assistance for each indicator of deprivation. Naturally because we are focusing here on single indicators of deprivation without looking at joint deprivation, the poverty measurement of interest is the unadjusted headcount ratio $(H)$ in comparison to the adjusted headcount ratio $\left(M_{0}\right)$ used prior. We find beneficiary households are five to six percentage points less deprived in terms of dietary diversity, food security and heating. These former results regarding dietary diversity and food security are particularly important when considering the severity of malnutrition in Afghanistan, and may be due to less overcrowding among extended families, increased household income directed towards basic necessities or more subsistence farming on newly acquired land. Our results on heating are more intuitive given that it is no doubt easier to keep warm with a roof over one's head.

\section{Sensitivity Analysis}

As explained, the results from propensity score matching are based on the assumption of unconfoundedness. This assumes selection into treatment is independent of potential outcomes given a set of observable characteristics. The influence of unobservable factors may however still be a concern giving rise to a hidden bias (Caliendo et al., 2005). To assess the sensitivity of our results to hidden bias, we conduct a sensitivity analysis following Rosenbaum's (2002) bounding approach.

Tables 30 and 31 present the Mantel and Haenszel (1959) test statistic of the treatment effect for overall MPI and individual outcome Dietary Diversity, respectively, when there is hypothetically no hidden bias $(\Gamma=1)$ and when the hidden bias increases by increments of 0.05 until $\Gamma=1.50$. The results for all other statistically significant outcomes can be found in Tables A6.3 - A6.6 in the appendix. The basic idea is to measure the amount of hidden bias necessary for unobservable factors to adversely influence our interpretation of the average treatment effect on the treated. Because of the negative estimated treatment effects for both MPI and Dietary Diversity, we focus on the bounds under the assumption that we have underestimated the true treatment effect ( $Q m h-)$ and its corresponding significance level (pmh-). 
For $M P I$, the treatment effect under the assumption of no hidden bias $(\Gamma=1)$ is significant corroborating our results, but loses significance at a relatively low level of gamma $(\Gamma=1.15)$. This critical value suggests the treatment effect is sensitive to bias to the extent that individuals with the same $\mathrm{x}$-vector of covariates differ in their odds of participation by a factor of 15 percent. Still, the treatment effect regains significance at a higher level of gamma $(\Gamma=1.40)$ where it becomes more significant for increasing levels. For Dietary Diversity, the treatment effect again is highly significant under the assumption of no hidden bias $(\Gamma=1)$ and remains significant up until a higher level of gamma $(\Gamma=1.35)$, and likewise regains significance at a higher level $(\Gamma=1.60)$. Overall, the sensitivity analysis suggests that we can be confident that unobserved heterogeneity is not driving our results.

Table 30: Mantel-Haenszel bounds for Outcome $=$ MPI

\begin{tabular}{lllll}
\hline \hline Gamma $(\Gamma)$ & Qmh + & Qmh- & pmh+ & pmh- \\
\hline$\Gamma=1$ & 3.2203 & 3.2203 & 0.0006 & 0.0006 \\
$\Gamma=1.05$ & 3.9173 & 2.5249 & 0.0000 & 0.0058 \\
$\Gamma=1.10$ & 4.5822 & 1.8619 & 0.0000 & 0.0313 \\
$\Gamma=1.15$ & 5.2183 & 1.2286 & 0.0000 & 0.1096 \\
$\Gamma=1.20$ & 5.8281 & 0.6226 & 0.0000 & 0.2668 \\
$\Gamma=1.25$ & 6.4139 & 0.0413 & 0.0000 & 0.4835 \\
$\Gamma=1.30$ & 6.9776 & 0.4468 & 0.0000 & 0.3275 \\
$\Gamma=1.35$ & 7.5208 & 0.9842 & 0.0000 & 0.1625 \\
$\Gamma=1.40$ & 8.0452 & 1.5021 & 0.0000 & 0.0665 \\
$\Gamma=1.45$ & 8.5520 & 2.0020 & 0.0000 & 0.0226 \\
$\Gamma=1.50$ & 9.0424 & 2.4851 & 0.0000 & 0.0065 \\
$\Gamma=1.55$ & 9.5177 & 2.9527 & 0.0000 & 0.0016 \\
$\Gamma=1.60$ & 9.9787 & 3.4057 & 0.0000 & 0.0003 \\
\hline$N o t e:$ & & 0.40. & 0.000
\end{tabular}

Note: radius matching method with caliper of 0.40 . Gamma $(\Gamma)$ : odds of differential assignment due to unobserved factors. Q_mh+: Mantel-Haenszel statistic (assumption: overestimation of treatment effect). Q_mh-: Mantel-Haenszel statistic (assumption: underestimation of treatment effect). $\mathrm{p} \_\mathrm{mh}+$ : significance level (assumption: overestimation of treatment effect). p_mh-: significance level (assumption: underestimation of treatment effect). 
Table 31: Mantel-Haenszel bounds for Outcome = Dietary Diversity

\begin{tabular}{lcccc}
\hline \hline Gamma $(\Gamma)$ & Qmh + & Qmh- & pmh+ & pmh- \\
\hline$\Gamma=1$ & 5.6079 & 5.6079 & 0.0000 & 0.0000 \\
$\Gamma=1.05$ & 6.3468 & 4.8714 & 0.0000 & 0.0000 \\
$\Gamma=1.10$ & 7.0516 & 4.1691 & 0.0000 & 0.0000 \\
$\Gamma=1.15$ & 7.7259 & 3.4986 & 0.0000 & 0.0002 \\
$\Gamma=1.20$ & 8.3725 & 2.8571 & 0.0000 & 0.0021 \\
$\Gamma=1.25$ & 8.9936 & 2.2421 & 0.0000 & 0.0125 \\
$\Gamma=1.30$ & 9.5913 & 1.6514 & 0.0000 & 0.0493 \\
$\Gamma=1.35$ & 10.1673 & 1.0832 & 0.0000 & 0.1394 \\
$\Gamma=1.40$ & 10.7233 & 0.5358 & 0.0000 & 0.2961 \\
$\Gamma=1.45$ & 11.2607 & 0.0076 & 0.0000 & 0.4970 \\
$\Gamma=1.50$ & 11.7807 & 0.4362 & 0.0000 & 0.3313 \\
\hline
\end{tabular}

Note: radius matching method with caliper of 0.40 . Gamma $(\Gamma)$ : odds of differential assignment due to unobserved factors. Q mh+: Mantel-Haenszel statistic (assumption: overestimation of treatment effect). Q_mh-: Mantel-Haenszel statistic (assumption: underestimation of treatment effect). $\mathrm{p} \_\mathrm{mh}+$ : significance level (assumption: overestimation of treatment effect). p_mh-: significance level (assumption: underestimation of treatment effect).

\subsection{Conclusion}

In this study we conduct a rigorous impact evaluation of the UNHCR shelter assistance program in Afghanistan over the period 2009 to 2011. Our motivation stems from the fact that post-return assistance, and more specifically the resolution of lost housing and property, is commonly understood as a key ingredient in sustainable return and reintegration. Given the infeasibility of randomizing shelter assistance to those repatriated, we implement a variety of matching techniques to insulate our results from selection bias. Moreover, we take advantage of a multidimensional approach to poverty measurement in order to holistically measure the impact on household well-being over a range of socio-economic indicators. Such an approach is arguably more relevant for analyzing programs such as that of the UNHCR, where the objectives are multifaceted.

Our analysis finds that shelter assistance has a statistically significant and negative effect on multidimensional poverty, as beneficiary households are on average three percentage points less poor overall, when considering the adjusted headcount ratio $\left(M_{0}\right)$, in comparison to their non-beneficiary counterparts. Moreover, in terms of 
the individual indicators of deprivation beneficiaries are five to six percentage points better off when it comes to dietary diversity, food security and heating. This leads us to conclude that UNHCR's shelter assistance program in Afghanistan provides a clear benefit aside from basic accommodation. Keeping in mind the severity of chronic malnutrition throughout Afghanistan, these findings regarding food security and dietary diversity are particularly encouraging.

Nevertheless, it is important to bear in mind the magnitude of our results as well as the program's lack of effect on those variables related to economic well-being in particular. Taking into consideration the broad objectives of the UNHCR program, we find little evidence to suggest that shelter assistance greatly contributes to improving the livelihood potential of the beneficiary households since the impact of the program on household deprivation in terms of debt, income sources and the number of assets are all statistically insignificant. Moreover, the program appears to have no effect on school attendance, arguably an indication for future livelihood potential, electricity or water. It might therefore be prudent to roll back any overlyambitious expectations of the program having an immediate effect on households' livelihoods, and rather describe shelter assistance in its current form as a valuable humanitarian intervention that provides much needed basic support to some of the most vulnerable households in the community. 


\section{Works Cited}

Alderman, H., Hoddinott, J., \& Kinsey, B. (2006). Long Term Consequences of Early Childhood Malnutrition. Oxford Economic Papers, 58(3), 450 - 474.

Alkire, S., \& Foster, J. (2011). Counting and multidimensional poverty measurement. Journal of Public Economics, 95, 476 - 487.

Alkire, S., \& Santos, M. E. (2014). Measuring Acute Poverty in the Developing World: Robustness and Scope of Multidimensional Poverty Index. World Development, 59, 251 - 274.

Austin, P. C. (2011). Optimal caliper widths for propensity-score matching with estimating differences in means and differences in proportions in observational studies. Pharmaceutical Statistics, 10(2), 150 - 161.

Banerjee, A. V., \& Duflo, E. (2011). Poor Economics: A Radical Rethinking of the Way to Fight Global Poverty. New York: Public Affairs.

Becker, S., \& Caliendo, M. (2007). Sensitivity analysis for average treatment effects. The Stata Journal, 7(1), 71 - 83.

Bijwaard, G., Schluter, C., \& Wahba, J. (2014). The impact of labour market dynamics on the return-migration of immigrants. Review of Economics \& Statistics, 96(3), 483 - 494.

Black, R., \& Gent, S. (2006). Sustainable Return in Post-conflict Contexts. International Migration, 44(3), 15 - 38.

Black, R., \& Koser, K. (1999). The End of the Refugee Cycle? In R. Black, \& K. Koser, The End of the Refugee Cycle? Refugee Repatriation and Reconstruction. New York/ Oxford: Berghahn Books.

Black, R., Koser, K., Munk, K., Atfield, G., D'Onofrio, D., \& Tiemoko, R. (2004). Understanding Voluntary Return. Home Office Online Report 50/04. London: Home Office.

Blattman, C., \& Miquel, E. (2010). Civil War. Journal of Economic Literature, 48(1), 3 - 57.

Bundervoet, T., Verwimp, P., \& Akresh, R. (2008). Health and Civil War in Rural Burundi. The Journal of Human Resources, 44(2), 536 - 463.

Caliendo, M., \& Kopeinig, S. (2008). Some Practical Guidance for the Implementation of Propensity Score Matching. Journal of Economic Surveys, 22(1), $31-72$. 
Caliendo, M., Reinhard, H., \& Thomsen, S. L. (2005). The Employment Effects of Job Creation Schemes in Germany: A Microeconometric Evaluation. (Discussion Paper 1512). The Institute for the Study of Labor.

Central Statistics Office (CSO). (2014). National Risk and Vulnerability Assessment 2011/2012. Afghanistan Living Conditions Survey. Kabul: Central Statistics Office.

Dustmann, C. (1997). Return migration, uncertainty and precautionary savings. Journal of Development Economics, 52(2), 395 - 316.

Ferretti, S., \& Ashmore, J. (2010). Shelter Evaluation Afghanistan: Final Report. Oslo: Norwegian Refugee Council.

GHK Consulting. (2012). Evaluation of the Danish Region of Origin of Support of Afghanistan. London: GHK Consulting.

Imai, K. S., \& Azam, M. D. (2010). Does Microfinance Reduce Poverty in Bangladesh? New Evidence from Household Panel Data. Journal of Development Studies, 48(5), 633 - 653.

Jalan, J., \& Ravallion, M. (2003). Does piped water reduce diarrhea for children in rural India? Journal of Econometrics, 112(1), 153 - 173.

Koser, K. (2001). The return and reintegration of rejected asylum seekers and irregular migrants. (Migration Research Series 4). Geneva: IOM.

Kronenfeld, D. A. (2008). Afghan Refugees in Pakistan: Not All Refugees, Not Always in Pakistan, Not Necessarily Afghan? Journal of Refugee Studies, $21(1), 43-63$.

Leckie, S. (2000). Housing and Property Issues for Refugees and Internally Displaced Persons in the Context of Return: Key Considerations for UNHCR Policy and Practice. Refugee Survey Quarterly, 19(3), 5 - 63.

Maastricht Graduate School of Governance (MGSoG); Samuel Hall Consulting. (2013). Evaluation of the UNHCR Shelter Assistance Programme: Full Report. MGSoG.

MacDonald, I. (2010). Afghanistan's reintegration challenges: land and housing. Oslo: Norwegian Refugee Centre.

MacDonald, I. (2011). Landlessness and Insecurity: Obstacles to Reintegration in Afghanistan. Washington D. C.: Middle East Institute-Fondation pour la Recherche Strategique.

Mantel, N., \& Haenszel, W. (1959). Statistical Aspects of the Analysis of Data from Retrospective Studies of Disease. Journal of the National Cancer Institute, 22, 719 - 748. 
O'Leary, A. (2014). 2014 and beyond: implications for displacement. Forced Migration Review, 46, 4 - 6.

Reed, S., \& Foley, C. (2009). Land and Property: Challenges and Opportunities for Returnees and Internally Displaced People in Afghanistan. Oslo: Norwegian Refugee Council.

Robano, V., \& Smith, S. C. (2013). Multidimensional targeting and evaluation: General framework with an application to a poverty program in Bangladesh. (OPHI Working Paper 65). Oxford Poverty and Human Development Initiative, University of Oxford.

Rosenbaum, P. R. (2002). Observational Studies. New York: Springer.

Rosenbaum, P. R., \& Rubin, D. B. (1983). The central role of the propensity score in observational studies for causal effects. Biometrica, 70(1), 41 - 55.

Simmons, A. (2001). Introduction: What Are the Conditions for Successful Refugee Return? Refugee, 19(3), 1 - 2.

Stark, O. (1992). The Migration of Labor. Oxford: Blackwell.

Tyler, D. (2014). Reframing solutions for Afghan refugees. Forced Migration Review, 46, 18 - 21.

United Nations International Children's Emergency Fund (UNICEF). (2009). Tracking Progress on Child and Maternal Nutrition: A survival and development priority. New York: UNICEF.

United Nations High Commisioner for Refugees (UNHCR). (2005). Shelter Programme Monitoring and Evaluation: Final Report. Geneva: UNHCR.

United Nations High Commisioner for Refugees (UNHCR). (2011). Shelter Assistance Guidelines: Updated. Geneva: UNHCR.

United Nations High Commisioner for Refugees (UNHCR). (2012a). Persons with Specific Needs (PSN): Assistance Guidelines. Geneva: UNHCR.

United Nations High Commisioner for Refugees (UNHCR). (2012b). Programme Outline: The Voluntary Return and Reintegration Programme. Geneva: UNHCR.

United Nations High Commisioner for Refugees (UNHCR). (2015a). Global Trends: Forced Displacement in 2014. Geneva: UNHCR.

United Nations High Commissioner for Refugees (UNHCR). (2015b). UNHCR Statistical Online Population Database. Retrieved September 1, 2015, from $<$ www.unhcr.org/statistics/populationdatabase $>$. 
Does Shelter Assistance Reduce Poverty?

United Nations Office for the Coordination of Humanitarian Affairs (UNOCHA). (2009). Afghanistan Common Humanitarian Action Plan 2009. Geneva: UNOCHA. 
Chapter 6

\section{Appendix}

Table A6.1: Sample

\begin{tabular}{|c|c|c|c|}
\hline \multicolumn{4}{|c|}{ Shelter Assistance } \\
\hline Province & Non-Beneficiary & Beneficiary & Total \\
\hline \multirow[t]{2}{*}{ Kabul } & 174 & 193 & 367 \\
\hline & $9.23 \%$ & $9.82 \%$ & $9.53 \%$ \\
\hline \multirow[t]{2}{*}{ Parwan } & 81 & 95 & 176 \\
\hline & $4.30 \%$ & $4.83 \%$ & $4.57 \%$ \\
\hline \multirow[t]{2}{*}{ Bamyan } & 26 & 31 & 57 \\
\hline & $1.38 \%$ & $1.58 \%$ & $1.48 \%$ \\
\hline \multirow[t]{2}{*}{ Laghman } & 133 & 159 & 292 \\
\hline & $7.06 \%$ & $8.09 \%$ & $7.58 \%$ \\
\hline \multirow[t]{2}{*}{ Nangarhar } & 787 & 775 & 1,562 \\
\hline & $41.75 \%$ & $39.42 \%$ & $40.56 \%$ \\
\hline \multirow[t]{2}{*}{ Balkh } & 51 & 44 & 95 \\
\hline & $2.71 \%$ & $2.24 \%$ & $2.47 \%$ \\
\hline \multirow[t]{2}{*}{ Faryab } & 92 & 73 & 165 \\
\hline & $4.88 \%$ & $3.71 \%$ & $4.28 \%$ \\
\hline \multirow[t]{2}{*}{ Jawzjan } & 89 & 102 & 191 \\
\hline & $4.72 \%$ & $5.19 \%$ & $4.96 \%$ \\
\hline \multirow[t]{2}{*}{ Sari Pul } & 37 & 51 & 88 \\
\hline & $1.96 \%$ & $2.59 \%$ & $2.29 \%$ \\
\hline \multirow[t]{2}{*}{ Kunduz } & 57 & 58 & 115 \\
\hline & $3.02 \%$ & $2.95 \%$ & $2.99 \%$ \\
\hline \multirow[t]{2}{*}{ Takhar } & 26 & 38 & 64 \\
\hline & $1.38 \%$ & $1.93 \%$ & $1.66 \%$ \\
\hline \multirow[t]{2}{*}{ Helmand } & 50 & 56 & 106 \\
\hline & $2.65 \%$ & $2.85 \%$ & $2.75 \%$ \\
\hline \multirow[t]{2}{*}{ Kandahar } & 78 & 75 & 153 \\
\hline & $4.14 \%$ & $3.81 \%$ & $3.97 \%$ \\
\hline \multirow[t]{2}{*}{ Paktya } & 113 & 119 & 232 \\
\hline & $5.99 \%$ & $6.05 \%$ & $6.02 \%$ \\
\hline \multirow[t]{2}{*}{ Herat } & 91 & 97 & 188 \\
\hline & $4.83 \%$ & $4.93 \%$ & $4.88 \%$ \\
\hline \multirow[t]{2}{*}{ Total } & 1,885 & 1,966 & 3,851 \\
\hline & $100 \%$ & $100 \%$ & $100 \%$ \\
\hline
\end{tabular}


Table A6.2: Results from first-stage probit

\begin{tabular}{|c|c|}
\hline & Marginal Effect \\
\hline \multicolumn{2}{|l|}{ Selection Variables } \\
\hline \multicolumn{2}{|l|}{ Subgroup Identification: } \\
\hline Refugee Returnee & $\begin{array}{c}0.1864 * * * \\
(3.66)\end{array}$ \\
\hline Non-Refugee Returnee & $\begin{array}{c}-0.0899 * \\
(-1.72)\end{array}$ \\
\hline IDP & $\begin{array}{c}-0.0565 \\
(-0.83)\end{array}$ \\
\hline No mobility & $\begin{array}{c}-0.2589 * * * \\
(-3.21)\end{array}$ \\
\hline HH Owns Land & $\begin{array}{c}0.0255 \\
(1.41)\end{array}$ \\
\hline Extremely Vulnerable & $\begin{array}{c}0.0326 * * \\
(2.06)\end{array}$ \\
\hline \multicolumn{2}{|l|}{ Migration Variables } \\
\hline Migrated: Pre-2001 & $\begin{array}{c}0.0230 \\
(0.75)\end{array}$ \\
\hline Destination: Pakistan & $\begin{array}{c}-0.0751 \\
(-1.43)\end{array}$ \\
\hline Returned: Post-2008 & $\begin{array}{c}0.0534 * * * \\
(2.58)\end{array}$ \\
\hline Returned: Home Ownership & $\begin{array}{c}0.0331 * \\
(1.73)\end{array}$ \\
\hline \multicolumn{2}{|l|}{ Control Variables } \\
\hline Household Size & $\begin{array}{c}0.0056^{* * *} \\
(3.26)\end{array}$ \\
\hline Married & $\begin{array}{c}0.0064 \\
(0.27)\end{array}$ \\
\hline \multicolumn{2}{|l|}{ Educational Attainment: } \\
\hline No formal & $\begin{array}{c}0.0856 \\
(1.37)\end{array}$ \\
\hline Primary & $\begin{array}{c}0.0489 \\
(0.75)\end{array}$ \\
\hline Secondary & $\begin{array}{c}0.0031 \\
(0.04)\end{array}$ \\
\hline Tertiary & $\begin{array}{c}\text { Reference } \\
(.)\end{array}$ \\
\hline Village dummies (128) & Yes \\
\hline $\mathrm{R}^{2}$ & 0.1436 \\
\hline $\mathrm{N}$ & 3717 \\
\hline
\end{tabular}


Chapter 6

Table A6.3: Mantel-Haenszel bounds for Outcome = Dim2: Health \& Edu.

\begin{tabular}{lcccc}
\hline \hline Gamma $(\Gamma)$ & Qmh+ & Qmh- & pmh+ & pmh- \\
\hline$\Gamma=1$ & 5.2441 & 5.2441 & 0.0000 & 0.0000 \\
$\Gamma=1.05$ & 5.9785 & 4.5121 & 0.0000 & 0.0000 \\
$\Gamma=1.10$ & 6.6788 & 3.8141 & 0.0000 & 0.0001 \\
$\Gamma=1.15$ & 7.3490 & 3.1477 & 0.0000 & 0.0008 \\
$\Gamma=1.20$ & 7.9915 & 2.5100 & 0.0000 & 0.0060 \\
$\Gamma=1.25$ & 8.6088 & 1.8987 & 0.0000 & 0.0288 \\
$\Gamma=1.30$ & 9.2027 & 1.3115 & 0.0000 & 0.0948 \\
$\Gamma=1.35$ & 9.7752 & 0.7466 & 0.0000 & 0.2276 \\
$\Gamma=1.40$ & 10.3277 & 0.2024 & 0.0000 & 0.4198 \\
$\Gamma=1.45$ & 10.8618 & 0.2559 & 0.0000 & 0.3990 \\
$\Gamma=1.50$ & 11.3786 & 0.7632 & 0.0000 & 0.2227
\end{tabular}

Note: radius matching method with caliper of 0.40 . Gamma $(\Gamma)$ : odds of differential assignment due to unobserved factors. Q_mh+: Mantel-Haenszel statistic (assumption: overestimation of treatment effect). Q_mh-: Mantel-Haenszel statistic (assumption: underestimation of treatment effect). p_mh+: significance level (assumption: overestimation of treatment effect). p_mh-: significance level (assumption: underestimation of treatment effect).

Table A6.4: Mantel-Haenszel bounds for Outcome = Dim3: Basic Services

\begin{tabular}{lcccc}
\hline \hline Gamma $(\Gamma)$ & Qmh + & Qmh- & pmh+ & pmh- \\
\hline$\Gamma=1$ & 1.2649 & 1.2649 & 0.1030 & 0.1030 \\
$\Gamma=1.05$ & 1.8822 & 0.6483 & 0.0299 & 0.2584 \\
$\Gamma=1.10$ & 2.4711 & 0.0604 & 0.0067 & 0.4759 \\
$\Gamma=1.15$ & 3.0345 & 0.4221 & 0.0012 & 0.3365 \\
$\Gamma=1.20$ & 3.5745 & 0.9600 & 0.0002 & 0.1685 \\
$\Gamma=1.25$ & 4.0932 & 1.4761 & 0.0000 & 0.0700 \\
$\Gamma=1.30$ & 4.5924 & 1.9723 & 0.0000 & 0.0243 \\
$\Gamma=1.35$ & 5.0736 & 2.4501 & 0.0000 & 0.0071 \\
$\Gamma=1.40$ & 5.5381 & 2.9109 & 0.0000 & 0.0018 \\
$\Gamma=1.45$ & 5.9871 & 3.3560 & 0.0000 & 0.0004 \\
$\Gamma=1.50$ & 6.4218 & 3.7864 & 0.0000 & 0.0001 \\
\hline
\end{tabular}

Note: radius matching method with caliper of 0.40 . Gamma $(\Gamma)$ : odds of differential assignment due to unobserved factors. Q_mh+: Mantel-Haenszel statistic (assumption: overestimation of treatment effect). Q_mh-: Mantel-Haenszel statistic (assumption: underestimation of treatment effect). p_mh+: significance level (assumption: overestimation of treatment effect). p_mh-: significance level (assumption: underestimation of treatment effect). 
Table A6.5: Mantel-Haenszel bounds for Outcome $=$ Food Security

\begin{tabular}{lcccc}
\hline \hline Gamma $(\Gamma)$ & Qmh + & Qmh- & pmh+ & pmh- \\
\hline$\Gamma=1$ & 3.5990 & 3.5990 & 0.0002 & 0.0002 \\
$\Gamma=1.05$ & 4.3149 & 2.8847 & 0.0000 & 0.0020 \\
$\Gamma=1.10$ & 4.9978 & 2.2037 & 0.0000 & 0.0138 \\
$\Gamma=1.15$ & 5.6511 & 1.5532 & 0.0000 & 0.0602 \\
$\Gamma=1.20$ & 6.2774 & 0.9307 & 0.0000 & 0.1760 \\
$\Gamma=1.25$ & 6.8790 & 0.3338 & 0.0000 & 0.3693 \\
$\Gamma=1.30$ & 7.4578 & 0.1713 & 0.0000 & 0.4320 \\
$\Gamma=1.35$ & 8.0156 & 0.7232 & 0.0000 & 0.2348 \\
$\Gamma=1.40$ & 8.5539 & 1.2550 & 0.0000 & 0.1047 \\
$\Gamma=1.45$ & 9.0742 & 1.7683 & 0.0000 & 0.0385 \\
$\Gamma=1.50$ & 9.5777 & 2.2644 & 0.0000 & 0.0118 \\
\hline
\end{tabular}

Note: radius matching method with caliper of 0.40 . Gamma $(\Gamma)$ : odds of differential assignment due to unobserved factors. Q_mh+: Mantel-Haenszel statistic (assumption: overestimation of treatment effect). Q_mh-: Mantel-Haenszel statistic (assumption: underestimation of treatment effect). $\mathrm{p} \_\mathrm{mh}+$ : significance level (assumption: overestimation of treatment effect). p_mh-: significance level (assumption: underestimation of treatment effect).

Table A6.6: Mantel-Haenszel bounds for Outcome $=$ Heating

\begin{tabular}{lcccc}
\hline \hline Gamma $(\Gamma)$ & Qmh+ & Qmh- & pmh+ & pmh- \\
\hline$\Gamma=1$ & 1.7104 & 1.7104 & 0.0436 & 0.0436 \\
$\Gamma=1.05$ & 2.3957 & 1.0258 & 0.0083 & 0.1525 \\
$\Gamma=1.10$ & 3.0495 & 0.3731 & 0.0011 & 0.3545 \\
$\Gamma=1.15$ & 3.6747 & 0.1792 & 0.0001 & 0.4289 \\
$\Gamma=1.20$ & 4.2740 & 0.7763 & 0.0000 & 0.2188 \\
$\Gamma=1.25$ & 4.8494 & 1.3491 & 0.0000 & 0.0887 \\
$\Gamma=1.30$ & 5.4030 & 1.8996 & 0.0000 & 0.0287 \\
$\Gamma=1.35$ & 5.9364 & 2.4296 & 0.0000 & 0.0076 \\
$\Gamma=1.40$ & 6.4512 & 2.9406 & 0.0000 & 0.0016 \\
$\Gamma=1.45$ & 6.9486 & 3.4341 & 0.0000 & 0.0003 \\
$\Gamma=1.50$ & 7.4300 & 3.9111 & 0.0000 & 0.0000 \\
\hline
\end{tabular}

Note: radius matching method with caliper of 0.40. Gamma ( $\Gamma)$ : odds of differential assignment due to unobserved factors. Q_mh+: Mantel-Haenszel statistic (assumption: overestimation of treatment effect). Q_mh-: Mantel-Haenszel statistic (assumption: underestimation of treatment effect). p_mh+: significance level (assumption: overestimation of treatment effect). p_mh-: significance level (assumption: underestimation of treatment effect). 
Figure A6.1: Incidence of multidimensional poverty $(H)$, by province

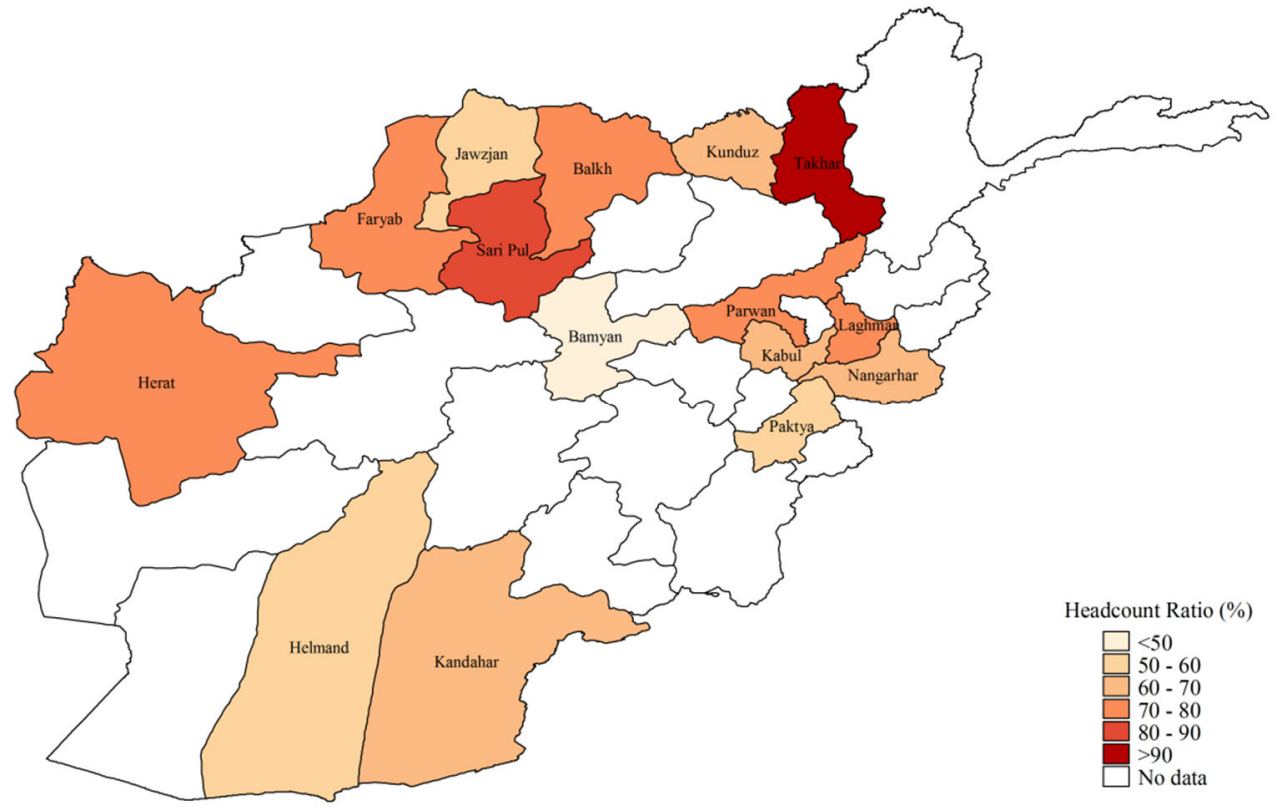

Figure A6.2: Intensity of multidimensional poverty $(A)$, by province

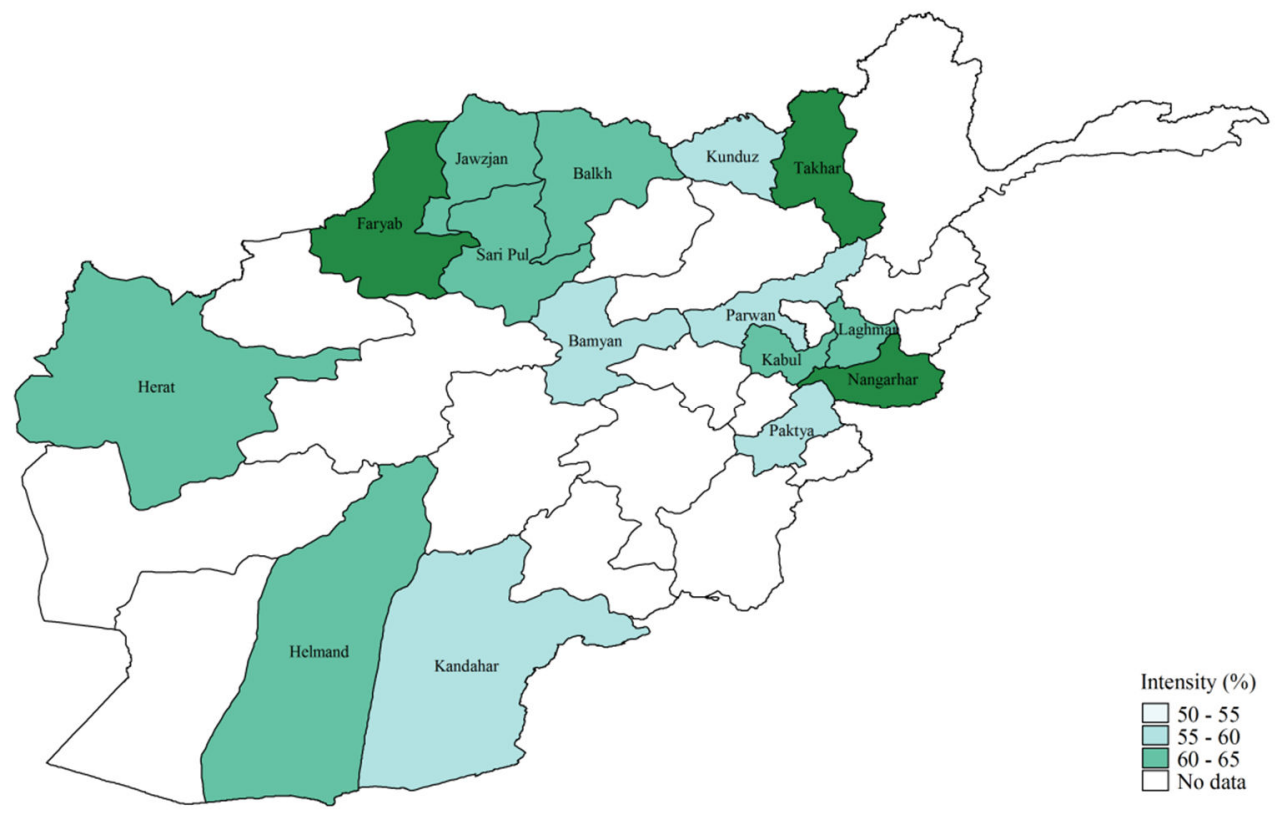


Figure A6.3: Pre-matched density of the propensity score

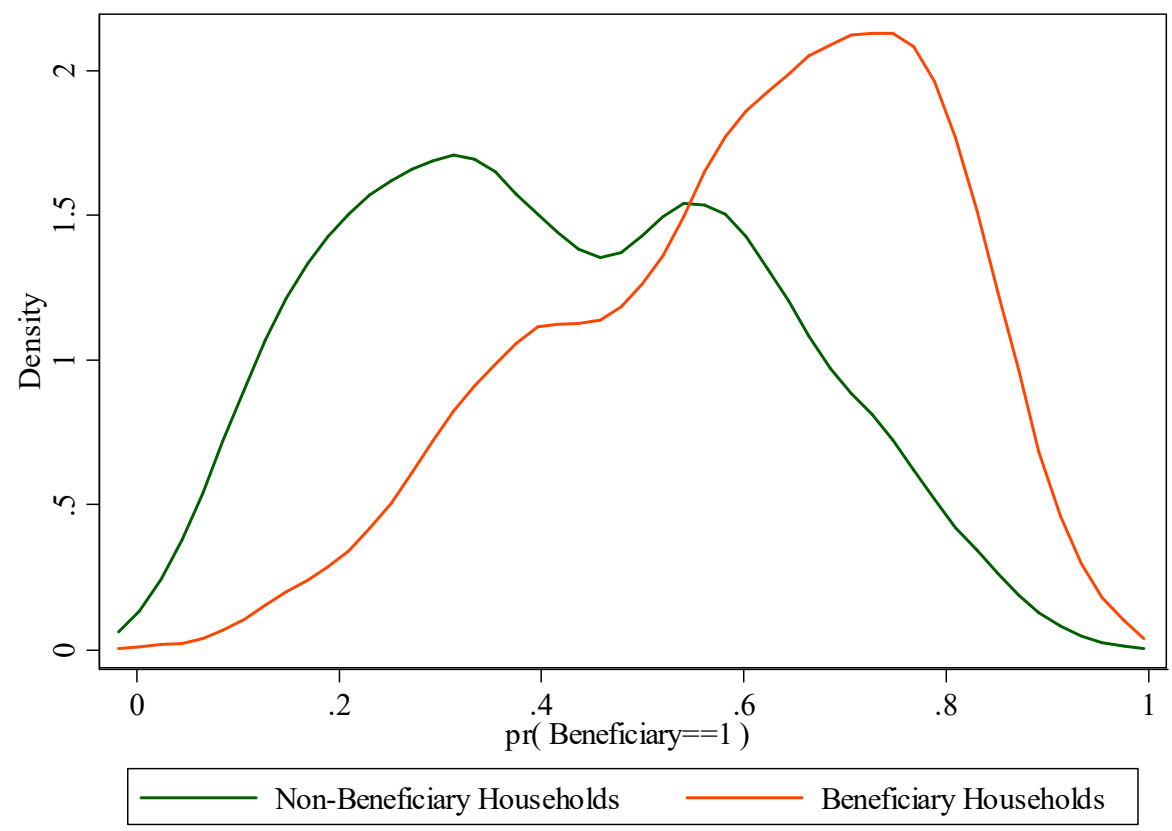

Figure A6.4: Matching based on the propensity score







\section{Chapter 7}

\section{Conclusion}

This dissertation has explored the relationship between conflict-related migration and development in Afghanistan, a country that has witnessed some of the largest refugee movements, internal displacement and return migration over the last four decades. The overarching aim has been to provide empirical evidence in a conflictaffected context rarely covered in the literature, as a way to contribute to our general understanding of the migration-development nexus in this particularly marginalized part of the world. This has been made possible by the use of two unique micro-level datasets that has allowed for quantitative analysis focused on one of three main sub-themes: 1) the causes of conflict-related migration; 2) its consequences for human development; and 3) policy response. In addition, these two datasets capture different types of migration flows prevalent in the Afghan setting providing the opportunity for each to be considered separately.

This concluding chapter reflects on the empirical research that makes up the core of this dissertation. First, a brief summary of the individual studies and corresponding results is presented in order to highlight some of the principal findings. Next, these studies are assessed in relation to certain conceptual and theoretical matters of interest, as well as in consideration of empirical points of significance. Lastly, the inherent limitations of this research are discussed, along with potential lines of future research.

\subsection{Research Summary}

\section{Causes of Conflict-related Migration}

Following the introductory chapter, Chapter 2 investigates the micro-level determinants of migration through a multidimensional lens of household vulnerability. The application of a multidimensional vulnerability index is motivated by the notion that in an insecure setting like that of Afghanistan it is reasonable to assume a particularly fine line between voluntary and forced 
migration. As such, it is arguably necessary to approach the subject through a broad spectrum which does not presuppose migration is strictly economic in nature, and takes into account both exposure to risk and lack of entitlements. After first constructing a profile of household vulnerability through individual indicators of deprivation along four principal dimensions, a regression analysis estimates its influence on migration intentions.

The results of the analysis found in Chapter 2 indicate vulnerable households are less likely to have concrete plans to migrate abroad. Indeed, a household categorized as multidimensionally vulnerable is found to be 10 percent less likely to have a member with intentions to move compared to non-vulnerable households, and this effect holds for the degree of vulnerability. This finding is in line with those hypotheses put forth by the New Economics of Labor Migration, in that it is not the 'poorest of the poor', or more appropriately for our purposes the 'most vulnerable of the vulnerable', that see migration as a possibility. Given the inherent costs and risks in leaving ones' home, it appears Afghan households have a realistic understanding about their capabilities to actually migrate, ultimately shaping their expectations and aspirations.

Chapter 3, conversely, explores whether there is evidence of migration as a household risk-coping strategy. To realize this, the analysis looks at the motivations behind remittance behavior differentiated by the way in which the migration episode was originally financed. By considering remittance behavior in relation to debt-financed migration in particular, it is possible to check for an implicit contractual agreement between migrant and household at origin. More specifically, if remittances are sent as part of a household strategy based on an implicit agreement, then there should be a positive relationship between remittance behavior and whether the costs of migration are covered by receiving a loan or gift.

The analysis in Chapter 3 shows no such evidence of a positive relationship, and remittance transfers are in fact lower both at the extensive and intensive margin for debt-financed migrants. Moreover, the results of certain individual and household characteristics are in line with what would be expected if altruism is the dominating motivation. In light of this finding, it is speculated that the sending of household members abroad as a risk-coping strategy in Afghanistan may be less 
about having an alternative source of income and more about having an alternative location to escape to if the security situation continues to deteriorate.

\section{Consequences for Human Development}

Chapter 4 examines the long-term consequences of displacement by inquiring how younger generations within displaced households may fare in their particular circumstances. Outcomes arguably crucial for the healthy development of children are compared between households that have experienced internal displacement and those that have not. As a way to infer future livelihood prospects of the child, these outcomes relate to human capital formation concentrating on both education and nutrition.

The analysis in Chapter 4 finds evidence that displacement leads to greater food insecurity and lower dietary diversity in those displaced households. In particular, a displaced household is 17 percent less likely to have eaten meat in the week prior to the survey, and those displaced households that had eaten meat ate 30 percent less in comparison to their non-displaced counterparts. Moreover, there is indication that displacement has a negative effect on school attendance, yet these estimates are not robust across locations. This suggests that the dynamics within the communities of displacement are more likely to influence educational outcomes regardless of whether the household is displaced or not. The overall conclusion that internally displaced households are a vulnerable sub-group within the population at large is not an unexpected revelation. What is salient, however, is the extent to which children of displaced households may be particularly afflicted, and the consequences this may have in the long-term.

Alternatively, Chapter 5 considers the reintegration of return migrants into the Afghan labor market, exploring the occupational choice of returnees whose initial migration was due to conflict or general insecurity. The analytical approach is twofold: first, to compare non-migrants and return migrants in regards to what influences their respective occupational choices; and second, to investigate the influence of the returnees' migration and return experience on their occupational choice. 
The analysis in Chapter 5 finds evidence that return migrants are less likely to be wage employed in comparison to non-migrants. The differences in occupational choice for non-migrants seem to arise from dissimilarities in socio-economic status, yet having left the country and since returned limits employment options regardless of status. On the other hand, having a strong social network within the local community helps a return migrants' chance of employment across all categories, whereas such an effect is only seen in regards to self-employment for non-migrants. In addition, when it comes to the migration and return experience of returnees a few key factors are found to be of particular consequence. For example, the amount of savings brought back upon return seems to be beneficial when it comes to becoming self-employed in both business and agriculture or herding. Conversely, individuals with concrete intentions to re-migrate are less likely to be occupied with agriculture or herding, potentially indicating labor-intensive activities such as farming necessitate greater investment in land and assets including livestock, making future movement less desirable.

\section{Policy Response}

Finally, Chapter 6 offers a policy-oriented study which evaluates a UNHCR shelter assistance program mainly targeting refugee returnees. The analysis adopts a multidimensional approach to poverty measurement and applies a propensity-score matching technique in order to compare similar beneficiary and non-beneficiary households. The primary objective is to assess whether shelter assistance realizes the program's stated aims of improving socio-economic conditions and strengthening the livelihood potential of beneficiary households.

The analysis in Chapter 6 shows that shelter assistance has an overall povertyreducing effect for those households benefiting from the program. By looking at particular indicators of deprivation in order to highlight specific factors driving this effect, the program is found to have the biggest impact on the dietary diversity, food security and heating of benefiting households. Given the prevalence of chronic malnutrition throughout Afghanistan, these results are encouraging. However, when taking into account the statistically insignificant effect on indicators related to economic well-being, one must come to terms with the fact that the program may have fallen short of its own overly-ambitious objectives, namely to greatly improve the socio-economic condition and thus livelihood 
potential of benefiting households. With this in mind, it is suggested that shelter assistance in its current form may be more appropriately described as simply a valuable humanitarian intervention that provides much needed basic support to some of the most vulnerable households in the community.

\subsection{Critical Reflections}

The relationship between migration and development in any conflict-affected environment is wrought with a number of complexities which makes it difficult and moreover unjustified to reduce to sweeping and overly-simplified generalizations. For this reason, the way in which the research question in each analysis is approached, and the results interpreted, has been deliberate and cautious. Nonetheless, by analyzing the relationship from both sides, as well as focusing on different types of migration flows, the research included in this dissertation has important implications for, and has made a contribution to, the field of study overall. In particular, Chapters 2 and 3 highlight fundamental conceptual and theoretical issues pertaining to the underlying causes of conflictrelated migration, while Chapters 4, 5 and 6 bring to light certain empirical points of significance concerning the consequences of forced migration and the evaluation of a relevant program.

\section{Conceptual and Theoretical Deliberations}

The main conceptual issue when it comes to conflict-related migration is the all-too often rigid division between voluntary and forced migration. Empirical research on migration seldom engages with the dynamics of conflict, and when it does often frames migration solely within a paradigm of conflict that marginalizes the notion of it as normal behavior (Bakewell \& Bonfiglio, 2013). Just like unemployment and poverty are all too commonly considered the sole motivations behind voluntary migration, violence and insecurity are often assumed to be the exclusive drivers of migration in conflict-affected environments. With respect to the latter, such an approach inherently discounts any agency on the part of the migrant as well as the potentially mixed influence of a range of economic, political, social-cultural and environmental factors (Van Hear et al., 2009; Bakewell, 2010; de Haas, 2011). While physical safety is surely a non-trivial element of the migration decisionmaking process in conflict environments, it is important to avoid reducing 
migration to atypical behavior that neglects the multiplicity of factors without qualified justification. Indeed, within the Afghan context such justification seems particularly warranted due in part to the variety of reasons individuals leave their homes (Kronenfeld, 2008). Considering migration not within a framework defined by this unsatisfactory dichotomy between voluntary and forced migration opens up space to more accurately reflect the complex realities of a situation on the ground.

In a similar vein, the most pressing theoretical issue relates to the need to integrate approaches emphasizing human agency of an individual with those focused on the greater structures - be they economic, political or other - within which an individual is embedded (King, 2012). As just discussed, it is not uncommon for research in conflict settings to arbitrarily assume away any deliberate decisionmaking on the part of the migrant, and instead inherently perceive movement as reactive to violence and insecurity. A more reasonable approach, rather, allows for the possibility that migration is but one of many potential strategic decisions by an individual or entire family, made in their best interest in light of structural constraints present in the surrounding environment. Framed in such a way, migration is perceived as a means to negotiate life in the face of conflict-related characteristics which may surely include violence and insecurity, but also other important yet sometimes less recognized issues associated with conflict like extreme poverty, limited employment opportunities and the lack of basic services, among others.

With respect to these conceptual and theoretical points, the analyses found in both Chapters 2 and 3 are developed to consider migration from Afghanistan not based on a simplistic economic interpretation, but also not strictly within a paradigm of conflict and subsequent forced migration. Rather, these studies are informed by the underpinnings of the New Economics of Labor Migration and livelihoods approach to development to understand how migration is influenced by certain characteristics of a conflict-affected environment and potentially used as an adaptive strategy. In Chapter 2 this translates into a framework based on household vulnerability, while in Chapter 3 the framework is one structured by household livelihood management. Accordingly, these studies make an effort to emphasize the importance of human agency and structural factors in the migration decisionmaking process. While not exhaustive given practical limitations, they take into account a range of possible influential factors that are clearly relevant, yet not 
exclusive to a conflict setting. As a result, each informs our understanding as to why an individual may want and ultimately choose to migrate from a conflictaffected environment, without fixating solely on whether they are forced to do so due to concerns for physical safety. This helps illustrate how the apparent divide between voluntary and forced migration might be bridged, while relying on an integrative theoretical perspective that acknowledges both agency and structure.

Looking beyond this still restricted theoretical framework however, it may be additionally beneficial to re-situate the concept of conflict-related migration within a broader framework of social transformation and change, as is only recently being considered for migration in general (see, e.g., de Haas, 2014). In many cases conflict-related migration can be thought of as less of an extraordinary occurrence in response to war, and more as a normal part and parcel of a wider social process that is characterized by conflict. This is especially relevant when a conflict event is not sudden and exceptional, but rather the context for daily life (Lubkemann, 2000). In this way, our understanding of migration at the macro-level might become less defined by conflict itself and more informed by the political, economic and social factors characterizing the conflict-affected environment. Of course at the micro-level the decision to migrate may be a direct result of violence and persecution and in that case be considered forced migration or displacement, but it is more appropriate from a theoretical position for that specific type of migration to be justified in those instances rather than assumed a priori without qualification. Such a notion is particularly applicable to the current case considering the long history of migration between Afghanistan and neighboring Pakistan and Iran, which necessitates a theoretical outlook that reflects migration as a common part of life for many Afghan households as opposed to simply a spontaneous reaction to war (Monsutti, 2008).

\section{Empirical Considerations}

From an empirical point of view, there is an apparent need for more quantitativelyoriented research on conflict-related migration taking into account that the majority of insight to date stems from 'small-N' qualitative scholarship. The economic literature on forced migration is still at an early stage and only recently has work that applies rigorous statistical methods on the topic begun to emerge (see, e.g., Ruiz \& Vargas-Silva, 2013 for a detailed review). Despite their being only a 
relatively few number of studies focused on the topic so far, its advancement is due to the fact that there is growing interest to better understand the consequences of displacement not only for those individuals driven from their homes, but also for the communities they leave behind as well as those they ultimately settle into. At the same time, and coinciding with a broader push for more evidence-based policymaking, there is an ever greater appreciation to assess the performance of humanitarian and development-oriented interventions in conflict and post-conflict settings.

One obvious reason why empirical research has been limited when it comes to conflict-related migration is the unsurprising absence of reliable data from those countries where it happens to take place. It is difficult to conduct large-scale data collection in such environments precisely because of high security risks and potentially low research capacity at the local level. Yet with more interest from national governments and development organizations to understand the dynamics of conflict and post-conflict environments as well as how their own development and humanitarian programs perform, creative partnerships are being forged to carry out more ambitious data collection efforts in places that have been noticeably underrepresented. Both the IS Academy 'Migration and Development: a World in Motion' project and UNHCR shelter assistance program evaluation in Afghanistan are good examples of ambitious data collection endeavors in a part of the world where reliable information is problematic.

Chapters 4 and 5 take advantage of the rich household-level data captured in both surveys to pursue a quantitative approach that explores the consequences of conflict-related migration. These two studies add to the budding literature on the economics of forced migration by providing evidence of displacement having an effect on those individuals forced from their homes, even after their eventual return. While the subject matter of each is rather focused, the findings contribute to a more thorough understanding of the impact of displacement in this particular environment, helping to inform future policy and program design targeting displaced populations. With respect to policy, Chapter 6 addresses whether a current shelter assistance program for refugee returnees meets its stated goals and objectives. The evaluation of such programs is an arguably crucial component to its overall design in order to gauge whether the end result adequately fulfills the original purpose for intended beneficiaries and, more importantly, avoids 
unforeseen negative consequences. The example of the shelter assistance program in Afghanistan is a case in point in which a detailed assessment allows for more realistic outlook on its relevance.

\subsection{Current Limitations and Future Lines of Study}

While the studies included in this dissertation help inform the general discussion on conflict-related migration and development in a variety of ways, they are not without their limitations. Some of this is the result of the methodological nature of the research itself, while another part is a reflection of the shortcomings within the field of study overall.

It should come as little surprise that Afghanistan makes for a particularly challenging case to pursue quantitative empirical research due to the noticeable lack of information on the general population. As already mentioned, there has not been an official national census to provide a precise sketch of the Afghan people since 1979 (Hanifi, 2006). Even though recent attempts by the Central Statistics Office have provided figures that are said to be representative at the national and provincial level (CSO, 2014), the difficulties in surveying certain insecure areas of the country as well as accurately estimating the many number of individuals that frequently traverse national borders are enough to give one pause. As a result, it is difficult to argue that data derived from any sample survey in the country is categorically generalizable, no matter how much effort was put into increasing the diversity and representativeness for a variety of groups. It is important, therefore, to view the empirical research here with a certain degree of caution. The main findings, for example, may be more indicative of the true nature of conflict-related migration in Afghanistan, rather than the truth itself. Nonetheless, in a universe of second-best options such evidence is still valuable and informs the greater discussion.

In a similar sense, the empirical methods used throughout this dissertation are dictated by the nature of the data available. Both the IS Academy and UNHCR datasets are of a cross-sectional nature which limits the use of arguably more powerful statistical models that incorporate changes over time into the analysis. In an unstable context like that of Afghanistan where the underlying security situation has the potential to shift in a short period of time, the capability to look at 
households at various moments would be of great benefit. Moreover, the availability of panel data would go far in allowing for better identification strategies and the ability to minimize issues related to endogeneity and more specifically selection. Even though the design of a panel survey in such a challenging setting would likely face a number of practical difficulties including high attrition and cost, future data collection endeavors would be wise to take into consideration the added value of such data.

The level and perspective of analysis are other important factors to bear in mind. The studies in this dissertation are all explicitly conducted at the micro-level, meaning either the individual or household is the main unit of analysis. This is made possible because of the detailed information both surveys were able to capture concerning individual and household characteristics. It was more problematic, however, to acquire comprehensive information about the communities within which these households were situated. Given the intention to understand how certain factors external to the household might influence migration behavior, more data at the meso-level would have allowed for a more exhaustive multi-level analysis on issues like local security, job opportunities or public services. Likewise, the survey was conducted within Afghanistan meaning information about Afghan migrants themselves, apart from the internally displaced population, are only indirectly conveyed through their family members. Linking migrant households to migrants abroad, or within Afghanistan, at the time of survey through non-conventional methods has the potential to open up new ground about the interaction between family members at various locations, and how that relates to the migration-development nexus.

Beyond these more methodological restrictions, the limited nature of a specific theoretical framework towards conflict-related migration within a more general field of study already considered under-theorized (Monsutti, 2008; Lindley, 2010; Bakewell, 2011; de Haas, 2014) is also of great consequence. Even though recent work has provided insight about how to potentially push the discussion beyond this supposed theoretical impasse (see, e.g. Bakewell, 2011; Bakewell \& Bonfiglio, 2013), a systematic account of those dynamics associated with conflict-related migration arguably still remains on the horizon. This is especially important for quantitative empirical research like that found here which would benefit greatly from further conceptual and theoretical insight in this area. As a result, one of the 
more promising lines of inquiry in the years to come still has to do with the advancement of theory specific to conflict-related migration.

Similarly, and in relation to viewing migration within a wider framework of social change, a much less appreciated topic specific to conflict and post-conflict settings has to do with the influence of the international community's presence on migration behavior. While ultimately an empirical question, it would be valuable to better understand how the sudden arrival, extended stay and subsequent exodus of a variety of foreign organizations - be they military, humanitarian or otherwise might affect the local structural factors that influence the migration decisionmaking process. In the Afghan case, one side of any such analysis would surely need to reflect the fluctuations in insecurity due to clashes between foreign forces and local insurgency groups, but another important aspect includes the vast amount of financial resources that has poured into the country since 2002. Such a research agenda would go a long way in informing how a diverse set of international interventions might have unintended consequences with respect to population change, and how those consequences might ultimately affect the success of those very same interventions in both the short- and long-term.

Additionally, the immobility of households in a conflict-affected environment is another interesting yet still arguably underappreciated area of investigation. Especially in terms of involuntary immobility, the divergence between an individual's aspirations and capability to relocate may be particularly relevant in an area of warfare (Carling, 2002). As such, there is much to gain from asking not only what causes certain households to move from their communities, but what influences others to remain in light of high risks and uncertainty. Considering the argument that migration is often a form of coping during conflict, the inability to move may be detrimental to the well-being of those left behind (Lubkemann, 2008). Especially if a substantial portion of a single community happens to suddenly disappear, the community-wide effect for those remaining may be particularly harmful. Overall, there is much to be known about how conflict disrupts or alters traditional migration strategies and what impact this may have for greater development-related outcomes.

On a similar and final note, and taking into consideration the nascent literature on the economics of forced migration, more empirical research is still required to 
explore how displacement has community-wide effects both at origin and destination. Focusing on the latter, there is an evident lack of information regarding how refugees and internally displaced persons impact those communities they move into or around, and how native populations adapt to their arrival. Aside from those traditional questions around social integration, more evidence is required on the type of productive activities refugees, for example, engage in both formally and informally, and the impacts their presence has on local economies. Especially in the case of protracted displacement, research looking into changes in expenditure patterns, commodity prices and business creation would go a long way in informing policymakers where to focus their attention and limited resources.

\subsection{Final Remarks}

Taking into consideration the recent scale of displacement due to war and persecution around the world, understanding the dynamics related to conflictrelated migration is of great interest. The research included in this dissertation has attempted to add to the collective knowledge on just this topic, exploring in a variety of empirical essays both the causes of conflict-related migration and its consequences for human development, along with a relevant policy response, in the case of Afghanistan. While generally informative to the overall discussion on migration and development in a conflict-affected setting rarely in focus, this concluding chapter also depicts a range of practical lines of inquiry for the years to come in an effort to push the boundaries of that discussion further along.

As for Afghanistan, the country sits at another important cross-road in its storied history. How it copes with the recent transition which shifts full responsibility of domestic security to the Afghan government remains to be seen, and has farreaching ramifications for the average Afghan. If the prospects for peace and stability continue to be hampered by the spread of insecurity as witnessed of late, it is likely that the recent trend of increased out-migration as well as internal displacement, and less return, will only intensify in the near term. The legacy of conflict-related migration in Afghanistan, therefore, can be expected to linger for the foreseeable future. 


\section{Works Cited}

Bakewell, O. (2010). Some Reflections on Structure and Agency in Migration Theory. Journal of Ethnic and Migration Studies, 36(10), 1689 - 1708.

Bakewell, O. (2011). Conceptualising displacement and migration: Processess, conditions, and categories. In K. Koser, \& S. Martin, The MigrationDisplacement Nexus: Patterns, Processes, and Policies. Oxford: Bergahn Books.

Bakewell, O., \& Bonfiglio, A. (2013). Moving Beyond Conflict: Re-framing mobility in the African Great Lakes region. (IMI Working Paper 71). International Migration Institute, University of Oxford.

Carling, J. (2002). Migration in the age of inovoluntary immobility: theoretical reflections and Cape Verdean experiences. Journal of Ethnic and Migration Studies, 28(1), 5 - 42.

Central Statistics Office (CSO). (2014). National Risk and Vulnerability Assessment 2011/2012. Afghanistan Living Conditions Survey. Kabul: Central Statistics Office.

de Haas, H. (2011). The determinants of international migration: conceptualising policy, origin and destination effects. (Working Paper 32). International Migration Institute, University of Oxford.

Hanifi, S. M. (2006). Material and Social Remittances to Afghanistan. In C. Westcott \& J. Brinkerhoff, Converting Migration Drains into Gains: Harnessing the Resources of Oversees Professionals. Manila: Asian Development Bank.

King, R. (2012). Theories and Typologies of Migration: An Overview and A Primer. (Willy Brandt Series of Working Papers in International Migration and Ethnic Relations 3/12). Malmo Institute for Studies of Migration, Diversity and Welare (MIM), Malmo University.

Kronenfeld, D. A. (2008). Afghan Refugees in Pakistan: Not All Refugees, Not Always in Pakistan, Not Necessarily Afghan? Journal of Refugee Studies, 21(1), $43-63$.

Lindley, A. (2010). Leaving Mogadishu: Towards a Sociology of Conflict-Related Mobility. Journal of Refugee Studies, 23(1), 2 - 22.

Lubkemann, S. C. (2000). The Transformation of Transnationality among Mozambican Migrants in South Africa. Canadian Journal of African Studies, 34(1), 41 - 63. 
Lubkemann, S. C. (2008). Involuntary Immobility: On a Theoretical Invisibility in Forced Migration Studies. Journal of Refugee Studies, 21(4), 454 - 475.

Monsutti, A. (2008). Afghan Migratory Strategies and the Three Solutions to the Refugee Problem. Refugee Survey Quarterly, 27(1), 58 - 73.

Ruiz, I., \& Vargas-Silva, C. (2013). The Economics of Forced Migration. Journal of Development Studies, 49(6), 772 - 784.

Van Hear, N., Brubaker, R., \& Bessa, T. (2009). Managing Mobility for Human Development: The Growing Salience of Mixed Migration. (Human Development Research Paper 2009/20). UNDP. 


\section{Valorization}

\section{Background}

Popular interest in the relationship between migration and development has grown considerably over the last two decades. As a consequence, there has been more and more academic research on the subject which has explored the way in which these two fundamental processes interrelate in a diverse set of environments. A notable limitation, however, has been the focus on those dynamics associated with economic migration from low- to high-income countries. This has led to a gap in the empirical literature when it comes to migration between developing countries, otherwise considered South-South migration, and other less voluntary forms of migration like refugee movements from countries afflicted by conflict.

This dissertation is a collection of empirical essays which attempts to fill this gap by exploring the link between conflict-related migration and development in the (post-) conflict environment of Afghanistan. The analyses are quantitative in nature relying on two unique micro-level datasets seldom available for such a setting. As such, the dissertation as a whole contributes to the general discussion on migration and development by providing evidence in a conflict-affected context rarely covered in the literature, and if so from a purely qualitative perspective. In addition, the varied types of migration flows prevalent in the context of Afghanistan are also considered in different chapters - namely, international migration, return migration and internal displacement - providing a uniquely wideranging account of the Afghan case as it relates to conflict-related migration and development.

\section{Relevance}

The real-world relevance of this work on the whole is evident once taking into consideration the significance of not only migration in general over recent time, but forced migration in particular. As mentioned in the introductory chapter, according to UNHCR there are more than 65 million individuals involuntarily displaced around the world representing the largest volume since World War II. Moreover, contrasting the popular image that countless refugees are flooding the shores of 
developed countries, around 86 percent of that total currently resides in other developing nations. These stark figures put into plain view the necessity to build our knowledge base and understanding of migration that is not solely driven by economic motivations, and to do so in contexts not simply categorized by southnorth trajectories.

This dissertation contributes to the building of that knowledge base by looking at both the causes of conflict-related migration and consequences for human development, as well as assessing a specific program targeting refugee returnees. In regards to the causes of conflict-related migration, Chapter 2 asks how household vulnerability might influence intentions to migrate. The application of a multidimensional vulnerability index is motivated by the notion that in an insecure setting like that of Afghanistan it is reasonable to assume a particularly fine line between voluntary and forced migration. As such, it is necessary to approach the subject through a broad spectrum which does not presuppose migration is strictly economic in nature, and takes into account both exposure to risk and lack of entitlements. The principal contribution is precisely this re-conceptualization of the underlying factors driving the motivation to migrate. While the concept of poverty is commonly used to investigate the causes of migration especially in contexts of labor migration, the use of this notion of vulnerability is both novel and appropriate given the systematic risks in the Afghan context.

Chapter 3 goes a step further, and investigates whether there is evidence of migration as a household risk-coping strategy. To do so, the analysis looks at the motivations behind remittance behavior differentiated by the way in which the migration episode was originally financed. By considering remittance behavior in relation to debt-financed migration in particular, it is possible to check for an implicit contractual agreement between migrant and household at origin which would suggest a household strategy. This study contributes to an extensive literature that focuses on testing a now well-established theoretical understanding of migration as a household arrangement, with direct implications for remittance behavior. However, it is the first to do so in the conflict-affected context of Afghanistan, which is argued to be relevant due to the high degree of insecurity and uncertainty over recent years. 
In relation to the consequences for human development, Chapter 4 examines the long-term consequences of displacement by inquiring how the younger generations within displaced households may fare in their particular circumstances. More specifically, outcomes arguably crucial for the healthy development of children are compared between households that have experienced internal displacement and those that have not. As a way to infer future livelihood prospects, these outcomes relate to human capital formation concentrating on both education and nutrition. The study contributes to a larger body of literature on the consequences of conflict, which routinely highlights displacement as a channel through which war may have an impact on human capital formation. Still, it is only in recent years that any empirical analysis has focused on displacement in particular, in contrast to war in general, and none in the context of Afghanistan.

In a similar line of inquiry concerning consequences, Chapter 5 considers the reintegration of return migrants into the Afghan labor market, exploring the occupational choice of returnees whose initial migration was due to conflict or general insecurity. The study is motivated by the fact that the reintegration of returnees greatly depends on their ability to access sustainable income-generating activities as a basis of their livelihood. The analytical approach is twofold: first, to compare non-migrants and return migrants in regards to what influences their respective occupational choices; and second, to investigate the influence of the returnees' migration and return experience on their occupational choice. The main contribution of this study is its focus on the return of those individuals whose original migration experience was due to concerns for safety, and as a result the insight concerning the labor market effect of forced migration and return. This is in contrast to the literature at large, where the attention is on the occupational choice of returnees who originally migrated to developed countries in search of employment.

Finally, the last study in this work reflects on a particular policy response related to conflict-related migration. Chapter 6 evaluates a shelter assistance program in Afghanistan mainly targeting returned refugees. The primary objective is to assess whether shelter assistance realizes the program's aims of improving socioeconomic conditions and strengthening the livelihood potential of beneficiary households. To this end, a multidimensional approach to poverty measurement is adopted, one based upon three principal dimensions: economic welfare, health and 
education, and basic services. From a practical point of view, this study provides the first judicious analysis of the largest shelter assistance program in Afghanistan, where the absence of basic shelter and land is routinely noted as a significant concern. From an academic perspective, it speaks to the literatures on refugee return, civil conflict and impact evaluation more generally.

\section{Audience and Outreach}

Given the topical nature of this dissertation, it has the benefit of being both academically and policy relevant widening the potential target audience. From a scientific point of view, various individual chapters contribute to furthering our understanding of specific issues around conflict-related migration and development, including both the motivations behind migration in this specific context and impact it may have now and in the long-term. Such studies should be of particular interest for migration scholars as they provide empirical evidence linked to already established theories of migration and development, and put others into question. At the same time they also emphasize the need for further inquiry, both from a theoretical and empirical standpoint, into conflict-related migration. In addition, the application of a multidimensional framework in various studies should be of interest for scholars of poverty measurement who in just recent years are beginning to explore ways to empirically apply such an innovative framework. Alternatively, from a policy point of view the practical relevance of these studies and the specific populations under the microscope should be of interest to those organizations working with refugees, internally displaced populations, returnees and vulnerable groups more generally. Indeed, it is in the public sectors benefit to better understand the target populations they happen to work with in order to better serve them.

As for outreach, every study included this dissertation has been presented in a diverse set of forums in an effort not only to receive considerable feedback on early versions, but also to disseminate findings to a wider audience. Such forums include international conferences, seminars and specialized workshops which were comprised of both academics and more policy-focused experts. Furthermore, three of the studies included here have already been published in peer-reviewed journals, while a fourth is forthcoming in an edited book. 


\section{Biography}

Craig Loschmann is a fellow at the Maastricht Graduate School of Governance and UNU-MERIT within Maastricht University. Since joining the doctoral program, his research has focused on the relationship between migration and development in (post-) conflict environments. Similarly, Craig has also worked on several migration-related projects during this time for a variety of institutions. Namely, he consulted for the Diaspora Forum for Development, evaluated a UNHCR shelter assistance program, provided external research for the Australian government's Department of Immigration and Border Protection, and coordinated fieldwork in Burundi for a DfID-funded research project by both the University of Oxford and Maastricht University. He is currently involved in a UNHCR-commissioned project to study the economic impact of Congolese refugees on host communities in Rwanda. Prior to joining Maastricht, Craig was a research assistant at the Navarra Center for International Development within the University of Navarra, as well as the Center for International Policy Studies within Fordham University where he received a dual MA degree in Economics and International Political Economy and Development. 



\section{MGSoG Dissertation Series}

Andrea Milan

Rural Livelihoods, Location and Vulnerable Environments:

Approaches to Migration in Mountain areas of Latin America

MGSoG Dissertation Series, nr 67 (2016)

Farida Lada

On Guarding the Welfare of Clinical Trial Subjects While Promoting Novel Drug Innovation: A Game Theoretical Approach

MGSoG Dissertation Series, nr 66 (2016)

Simona Vezzoli

Borders, Independence and Post-colonial Ties:

the Role of the State in Caribbean Migration

MGSoG Dissertation Series, nr 65 (2015)

Silvia Consuelo Gómez Soler

Civil Conflict and Education: How Does Exposure to Civil Conflict Affect Human Capital Accumulation? Evidence from Standardized Exit Exams in Colombia MGSoG Dissertation Series, nr 64 (2015)

Paula Nagler

Occupational Choice in the Developing World

MGSoG Dissertation Series, nr 63 (2015)

Jasmin Kientzel

Determinants of Professional Commitment to Environmental Sustainability

MGSoG Dissertation Series, nr 62 (2015)

Mehmet Güney Celbiş

Regional Policies: Convergence, Trade, and the Allocation of Public Capital

MGSoG Dissertation Series, nr 61 (2015) 
Florian Henning

Living Up to Standards: Interoperability Governance and Standards Adoption in Government Information Networks

MGSoG Dissertation Series, nr 60 (2015)

Niels P. Groen

The Never-Ending Project: Understanding E-Government Project Escalation

MGSoG Dissertation Series, nr 59 (2015)

Derek Copp

Teacher-Based Reactivity to Provincial Large-scale Assessment in Canada

MGSoG Dissertation Series, nr 58 (2015)

Michaella Vanore

Family-Member Migration and the Psychosocial Health Outcomes of Children in Moldova and Georgia

MGSoG Dissertation Series, nr 57 (2015)

Sonja Fransen

The Economic and Social Effects of Remittances and Return Migration in ConflictAffected Areas: The Case of Burundi

MGSoG Dissertation Series, nr 56 (2015)

Ibrahim Khalil Conteh

The Impact of Floods on Primary School Education in Zambia

MGSoG Dissertation Series, nr 55 (2015)

Richard Bluhm

Growth Dynamics and Development:

Essays in Applied Econometrics and Political Economy

MGSoG Dissertation Series, nr 54 (2015)

Nevena P. Zhelyazkova

Work-Family Reconciliation and Use of Parental Leave in Luxembourg: Empirical Analysis of Administrative Records

MGSoG Dissertation Series, nr 53 (2015) 
Sachin Kumar Badkas

Metachoice and Metadata:

Innovating with Environmental Policy Analysis in Europe

MGSoG Dissertation Series, nr 52 (2014)

Irina S. Burlacu

An Evaluation of Tax-Benefit Systems Impact on the Welfare of Frontier Workers:

The Case of Luxembourg and Belgium

MGSoG Dissertation Series, nr 51 (2014)

Özge Bilgili

Simultaneity in Transnational Migration Research:

Links Between Migrants' Host and Home Country Orientation

MGSoG Dissertation Series, nr 50 (2014)

Yulia Privalova Krieger

Reshaping the Big Agenda: Transnational Politics and Domestic Resistance:

Financial crisis and social protection reform in Bosnia and Herzegovina

MGSoG Dissertation Series, nr 49 (2014)

Marieke van Houte

Moving Back or Moving Forward? Return migration after conflict

MGSoG Dissertation Series, nr 48 (2014)

Oxana Slobozhan

Global Governance in the Management of Natural Resources:

The Case of the Extractive Industries Transparency Initiative (EITI)

MGSoG Dissertation Series, nr 47 (2014)

Luis Bernardo Mejia Guinand

The Changing Role of the Central Planning Offices in Latin America:

A Comparative Historical Analysis Perspective (1950-2013)

MGSoG Dissertation Series, $\mathrm{nr} 46$ (2014) 
Cheng Boon Ong

Ethnic Segregation in Housing, Schools and Neighbourhoods in the Netherlands

MGSoG Dissertation Series, $\mathrm{nr} 45$ (2014)

Luciana V. Cingolani

Bureaucracies for Development: Oxymoron or Reality?

Studies on State Capacity in Challenging Governance Contexts

MGSoG Dissertation Series, nr 44 (2014)

Carlos Cadena Gaitán

Green Politics in Latin American Cities - Sustainable Transport Agendas

MGSoG Dissertation Series, nr 43 (2014)

Katie Kuschminder

Female Return Migration and Reintegration Strategies in Ethiopia

MGSoG Dissertation Series, nr 42 (2014)

Metka Hercog

Highly-Skilled Migration and New Destination Countries

MGSoG Dissertation Series, nr 41 (2014)

Margaret Agaba Rugadya

Can Remittances Influence the Tenure and Quality of Housing in Uganda?

MGSoG Dissertation Series, $\mathrm{nr} 40$ (2014)

Ilire Agimi

New Governance Under Limited Statehood:

The Case of Local Government Reform in Kosovo

MGSoG Dissertation Series, nr 39 (2014)

Kristine Farla

Empirical Studies on Institutions, Policies and Economic Development MGSoG Dissertation Series, nr 38 (2013) 
Marina Petrovic

Social Assistance and Activation in the Pursuit of Happiness:

Shedding New Light on Old Policy Solutions to Social Exclusion

MGSoG Dissertation Series, nr 37 (2013)

Laura Torvinen

Assessing Governance Assessments: The Case of Mozambique Governance

Assessments in the Context of Aid Effectiveness Discourse

MGSoG Dissertation Series, nr 36 (2013)

Biniam Egu Bedasso

Institutional Change in the Long Shadow of Elites:

Essays on Institutions, Human Capital and Ethnicity in Developing Countries

MGSoG Dissertation Series, nr 35 (2013)

Sepideh Yousefzadeh Faal Deghati

Childhoods Embargoed: Constructing and Reconstructing Multidimensional Child Poverty in Iran 1984-2009

MGSoG Dissertation Series, nr 34 (2013)

Robert Bauchmüller

Investing in Early Childhood Care and Education:

The Impact of Quality on Inequality

MGSoG Dissertation Series, nr 33 (2013)

Martin Rehm

Unified Yet Separated: Empirical Study on the Impact of Hierarchical Positions within Communities of Learning

MGSoG Dissertation Series, nr 32 (2013)

Dorcas Mbuvi

Utility Reforms and Performance of the Urban Water Sector in Africa MGSoG Dissertation Series, nr 31 (2012) 
Lina Salanauskaite

Distributional Impacts of Public Policies:

Essays in Ex-Ante and Ex-Post Evaluation

MGSoG Dissertation Series, nr 30 (2012)

Esther Schüring

To Condition or not - is that the Question? An Analysis of the Effectiveness of ExAnte and Ex-Post Conditionality in Social Cash Transfer Programs

MGSoG Dissertation Series, nr 29 (2012)

Joe Abah

Strong Organisations in Weak States:

Atypical Public Sector Performance in Dysfunctional Environments

MGSoG Dissertation Series, nr 28 (2012)

Zina Samih Nimeh

Social Citizenship Rights: Inequality and Exclusion

MGSoG Dissertation Series, nr 27 (2012)

Lenka Eisenhamerová

Legitimacy of 'Humanitarian Military Intervention'

MGSoG Dissertation Series, nr 26 (2011)

Sonila Tomini

Informal Payments for Health Care Services in Albania

MGSoG Dissertation Series, nr 25 (2011)

Jinjing Li

Dynamic Microsimulation in Public Policy Evaluation

MGSoG Dissertation Series, nr 24 (2011)

Aziz Atamanov

Rural Nonfarm Employment and International Migration as Alternatives to Agricultural Employment: The Case of Kyrgyzstan

MGSoG Dissertation Series, nr 23 (2011) 
Frieda Vandeninden

Poverty Alleviation: Aid and Social Pensions

MGSoG Dissertation Series, nr 22 (2011)

Juliana Nyasha Tirivayi

The Welfare Effects of Integrating AIDS Treatment with Food Transfers:

Evidence from Zambia

MGSoG Dissertation Series, nr 21 (2011)

Agnieska Ewa Sowa

Who's Left Behind?

Social Dimensions of Health Transition and Utilization of Medical Care in Poland MGSoG Dissertation Series, nr 20 (2011)

Emmanaouil Sfakianakis

The Role of Private Actors in the Provision of Public Goods with Applications to Infrastructure and Financial Stability

MGSoG Dissertation Series, nr 19 (2011)

Siu Hing Lo

White Collars Green Sleeves: An Interonganizational Comparison of Determinants of Energy-Related Behaviors among Office Workers

MGSoG Dissertation Series, nr 18 (2011)

Treena $\mathrm{Wu}$

Constraints to Human Capital Investment in Developing Countries:

Using the Asian Financial Crisis in Indonesia as a Natural Experiment MGSoG Dissertation Series, nr 17 (2011)

Henry Espinoza Peña

Impact Evaluation of a Job-Training Programme for Disadvantaged Youths:

The Case of Projoven

MGSoG Dissertation Series, nr 16 (2011) 
Florian Tomini

Between Family and Friends:

Understanding the Interdependency of Private Transfers

MGSoG Dissertation Series, nr 15 (2010)

Michał Polalowski

The Institutional Transformation of Social Policy in East Central Europe:

Poland and Hungary in comparative and historical perspective

MGSoG Dissertation Series, nr 14 (2010)

Maha Ahmed

Defining, Measuring and Addressing Vulnerability:

The Case of Post Conflict Environments

MGSoG Dissertation Series, nr 13 (2010)

Pascal Beckers

Local Space and Economic Success:

The role of spatial segregation of migrants in the Netherlands

MGSoG Dissertation Series, nr 12 (2010)

Victor Cebotari

Conplicting Demands in Ethnically Diverse Societies:

Ethnopolitical Contention and Identity Values in Europe

MGSoG Dissertation Series, nr 11 (2010)

Dennis Gyllensporre

Competing and Complementary Perspectives on the EU as a Crisis Management Actor: An Examination of the Common Security and Defence Policy through the Lenses of Idealism and Realism

MGSoG Dissertation Series, nr 10 (2010)

Judit Vall Castello

Business Cycle and Policy Effects on Labour Market Transitions of Older and Disabled Workers in Spain

MGSoG Dissertation Series, nr. 9 (2010) 
Keetie Roelen

False Positives or Hidden Dimensions:

the definition and measurement of child poverty

MGSoG Dissertation Series, nr. 8 (2010)

Denisa Maria Sologon

Earning Dynamics in Europe

MGSoG Dissertation Series, nr. 7 (2010)

Melissa Siegel

Money and Mobility: Migration and Remittances

MGSoG Dissertation Series, nr. 6 (2010)

Jessica S. Hagen-Zanker

Modest Expectations: Causes and effects of migration on migrant households in source countries

MGSoG Dissertation Series, nr. 5 (2010)

Mirtha R. Muniz Castillo

Human Development and Autonomy in Project Aid:

Experiences from four bilateral projects in Nicaragua and El Salvador

MGSoG Dissertation Series, nr. 4 (2009)

Christiane Arndt

Governance Indicators

MGSoG Dissertation Series, nr. 3 (2009)

Britta Augsburg

Microfinance - Greater Good or Lesser Evil?

MGSoG Dissertation Series, nr. 2 (2009)

Geranda Notten

Measuring and Managing Poverty Risks

MGSoG Dissertation Series, nr. 1 (2008) 